Dissertação apresentada à Faculdade de Arquitetura e Urbanismo da Universidade de São Paulo para obtenção do título de Mestre em Arquitetura e Urbanismo.

Exemplar revisado e alterado em relação à versão original, sob responsabilidade do autor e anuência do orientador. A versão original, em formato digital, ficará arquivada na Biblioteca da Faculdade. São Paulo, 21 de julho de 2020.

Área de concentração: Paisagem e Ambiente.

Orientadora: Prof. ${ }^{a}$ Dr. $^{a}$ Maria de Assunção Ribeiro Franco 
Autorizo a reprodução e divulgação total ou parcial deste trabalho, por qualquer meio convencional ou eletrônico, para fins de estudo e pesquisa, desde que citada a fonte.

Catalogação na Publicação

Serviço Técnico de Biblioteca

Faculdade de Arquitetura e Urbanismo da Universidade de São Paulo

Leite, Laís Padilha

Infraestrutura verde aplicada ao alto e médio curso do Rio Tremembé- São Paulo (SP) / Laís Padilha Leite;

orientadora Maria de Assunção Ribeiro Franco. - São Paulo, 2020 .

$176 \mathrm{f}$.

Dissertação (Mestrado) - Faculdade de Arquitetura e Urbanismo da Universidade de São Paulo. Área de concentração: Paisagem e Ambiente.

1. Infraestrutura Verde. 2. Planejamento Ambiental. 3. Rio Tremembé. 4. Buffer Zone. I. Franco, Maria de Assunção Ribeiro, orient. II. Título.

Elaborada eletronicamente através do formulário disponível em: $<$ http://www.fau.usp.br/fichacatalografica/ $>$ 
Laís Padilha Leite

\section{Infraestrutura verde aplicada ao alto e médio curso do Rio Tremembé- São Paulo (SP)}

Dissertação apresentada à Faculdade de Arquitetura e Urbanismo da Universidade de São Paulo para obtenção do título de Mestre em Arquitetura e Urbanismo.

Aprovado em: 1

Banca Examinadora

Prof. Dr.

Instituição:

Julgamento:

Prof. Dr.

Instituição:

Julgamento:

Prof. Dr.

Instituição:

Julgamento: 
Aos meus pais, Maria Luiza e Denis Márcio, pelo amor e apoio incondicionais. Aos meus irmãos, Denise e Guilherme, pelo incentivo e amizade. 


\section{AGRADECIMENTOS}

À orientadora Prof. ${ }^{a}$ Dra. Maria de Assunção Ribeiro Franco pelo incentivo e apoio concedidos ao longo do desenvolvimento deste trabalho. Agradeço os conhecimentos transmitidos nas suas aulas que, associados às conversas no laboratório, funcionaram como valiosos estímulos neste caminho.

À toda equipe de pesquisadores do Laboratório LABVERDE da Faculdade de Arquitetura e Urbanismo da Universidade de São Paulo que, por meio de saberes compartilhados, contribuíram de alguma maneira para a construção e aperfeiçoamento desta pesquisa.

Ao CESAD, Seção Técnica de Geo Informação e Produção de Bases Digitais da Faculdade de Arquitetura e Urbanismo de São Paulo, com destaque para os integrantes Eunice, Ricardo e Edgar. Agradeço a disponibilidade em tirar dúvidas relacionadas ao software de processamento Qgis e por todo o suporte na elaboração dos mapas relativos às pesquisas desenvolvidas no laboratório LABVERDE.

Aos queridos amigos que tive a oportunidade de conhecer ao longo do mestrado. À Cintia, por seus sábios conselhos, apoio e incentivos concedidos desde os primeiros dias de aula. Ao Cleandho, amigo biólogo, pelas ricas conversas sobre vida, biologia e arquitetura e urbanismo. À Juliana, por sua companhia nos cafés e almoços, visão crítica e livros compartilhados. Agradeço todos os demais amigos que contribuíram de forma direta ou indireta para o desenvolvimento deste trabalho.

Ao Artur, por sua paciência, bondade e parceria. Aos meus avós, Raymundo e Maria de Jesus e às minhas tias, Lili e Claudinha, por terem me acolhido em São Paulo. Aos meus pais, Maria Luiza e Denis Márcio e aos meus irmãos, Denise e Guilherme, agradeço por terem emanado forças e estímulos ainda que de tão longe. 
"O grande rio tem seu trajeto, antes do mar imenso. Copiando-lhe a expressão, a alma percorre igualmente caminhos variados e etapas diversas, também recebe afluentes de conhecimentos, aqui e ali, avoluma-se em expressão e purifica-se em qualidade, antes de encontrar o oceano eterno da sabedoria". 


\section{RESUMO}

LEITE, Laís Padilha. Infraestrutura verde aplicada ao alto e médio curso do Rio Tremembé- São Paulo (SP). 2020. 176 f. Dissertação (Mestrado) - Faculdade de Arquitetura e Urbanismo de São Paulo São Paulo, São Paulo, 2020.

A infraestrutura verde orienta modificações no espaço urbano com a intenção de resgatar relações perdidas entre o homem e os espaços naturais da cidade. Esse instrumento encontra suas raízes no planejamento ambiental e assume a natureza como parte integrante do ambiente urbano, onde cursos d'água e fragmentos verdes estruturam uma malha capaz de oferecer amplo leque de benefícios às pessoas e demais seres vivos. Contudo, a consciência de que os componentes ambientais agregam valor à paisagem urbana ainda precisa ser muito desenvolvida nas cidades brasileiras. Como exemplo, cita-se a expansão urbana do município de São Paulo (SP) marcada pela erradicação de áreas verdes originais e retificação de seus rios, determinando um cenário repleto de problemas e incertezas. Neste sentido, o trabalho toma como objetivo investigar a aplicação da infraestrutura verde no alto e médio curso do Rio Tremembé localizado na zona norte do município de São Paulo (SP). A área de estudo assume como eixo linear a extensão do Rio Tremembé desde sua nascente original até alcançar a divisa com o distrito de Jaçanã e compreende ainda uma faixa envoltória de 500 metros para cada um dos lados, área de influência denominada buffer zone. A região enfrenta problemas relacionados à drenagem urbana ao mesmo tempo em que apresenta um contexto singular por integrar fragmentos remanescentes da Mata Atlântica, apresentando um grande potencial perante suas características ambientais. A pesquisa adota como método de aplicação o zoneamento ambiental desenvolvido pelo geógrafo Schutzer e, para tanto, se apoia em materiais iconográficos, dados bibliográficos, visitas a campo e levantamento de dados oferecidos pela Prefeitura de São Paulo. Ao final, o trabalho oferece diretrizes apoiadas nos princípios da infraestrutura verde que apontam para consonância entre as singularidades urbanas e naturais formadoras da paisagem local. 
Palavras- chave: Infraestrutura verde. Planejamento ambiental. Rio Tremembé. Buffer Zone. 


\section{ABSTRACT}

\section{LEITE, Laís Padilha. Green infrastructure applied to the high and medium course of}

the Tremembé river- São Paulo (SP). 2020. 176 f. Dissertation (Academic Master Degree) - College of Architecture and Urbanism, University of São Paulo, São Paulo, 2020.

The green infrastructure guides planning modifications to rescuing lost relationships between man and the cities natural spaces. This approach has its roots on environmental planning and admits nature as part of urban landscape, in a way that water bodies and green fragments compound a network with range of benefits to people and other living beings. However, the awareness around the value of natural components applied on urban landscape still must be highly improved on Brazilian cities. The urban growth of the city of São Paulo can be indicated as an example, which is known by the elimination of green original spaces and modifications of river flows, conforming an outlook composed by problems and doubts. On this way, this work aims to investigate the green infrastructure application on high and middle stream of Tremembé river located on the north zone of the city of São Paulo. The study area admits as linear axis the extension of Tremembé river since its source until reach the boundary of Jaçanã district including a wrap strip of 500 meters for each side, influence area named buffer zone. The region has been faced urban drainage problems although at the same time presents a unique context justified by the presence of reminiscent areas of Atlantic Florest and potential in face of its natural characteristics. The research adopts the method of environmental zoning developed by the geographer Schutzer and for so supports on iconographic materials, bibliographical data, field visits and data collection offered by municipal government of São Paulo. At the end, the work presents guidelines by principles of green infrastructure that indicate integration between urban and natural features that shapes local landscape.

Keywords: Green infrastructure. Environmental Planning. Tremembé River. Buffer Zone. 


\section{LISTA DE ILUSTRAÇÕES}

Figura 1- As pirâmides do Egito: uma reflexão da crescente autoconfiança do homem na natureza..

Figura 2- O padrão dos campos de arroz presentes na China ilustra a relação entre o homem e a natureza.

Figura 3- O estudo de qualidade para Wisconsin vincula qualidades visuais da paisagem às características ambientais naturais

Figura 4- O modelo "Bolo em camadas" apresentado por McHarg 36

Figura 5- O modelo de compartimento do sistema de Eugene Odum 37

Figura 6- Mapa que ilustra a configuração do Emerald Necklace..... 44

Figura 7- Parque Back Bay Fens atua no controle de enchentes. 45

Figura 8- A Riverway: via caminho arborizado ao longo das margens do rio Muddy....45

Figura 9- Espelho dágua presente no Jamaica Park .46

Figura 10- Visão da via- parque Commonwealth Avenue. 46

Figura 11- Localização do Rio Cheonggyecheon em Seoul. 48

Figura 12- Localização do Rio Cheonggyecheon em Seoul. 48

Figura 13- A Via Expressa Elevada Cheonggyecheon.

Figura 14- O rio Cheonggyecheon revitalizado após a demolição da Expressa Elevada

Figura 15- Caminho para pestres às margens renaturalizadas do rio.

Figura 16- Proximidade das pessoas com o rio.

Figura 17- Margens do rio como espaço de recreação e lazer..

Figura 18-Painel que mostra a diferença de temperatura da região 50

Figura 19 - Mapa da distribuição dos setores do Parque Nacional da Tijuca...... .52

Figura 20- Pico presente no Parque Nacional da Tijuca. 53

Figura 21 - Vista da Floresta da Tijuca a partir do alto do mirante. 53

Figura 22- Localização do Parque Natural Municipal do Iguaçu. .54

Figura 23- Localização do Parque Natural Municipal do Iguaçu. .54

Figura 24- Parque Nacional do Iguaçu .55

Figura 25- Raia Náutica com vista para a cidade de Curitiba. .55 
Figura 26- Esquema básico de uma rede de infraestrutura verde. 62

Figura 27- Imagem aérea de Estocolmo.......................................................................................65

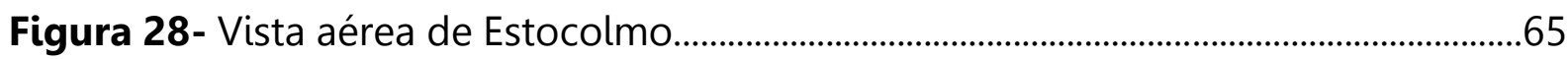

Figura 29- Túnel no Parque parque natural Südgelände........................................................66

Figura 30- Caminho suspenso entre a floresta no parque natural Südgelände ...........62

Figuras 31, 32 e 33- Parque Bishan- Ang Mo Kio ...................................................................65

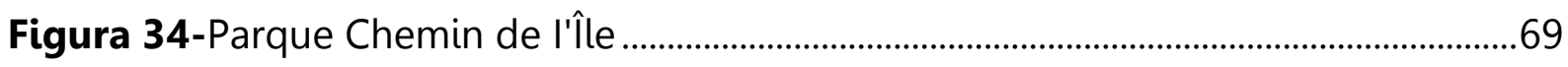

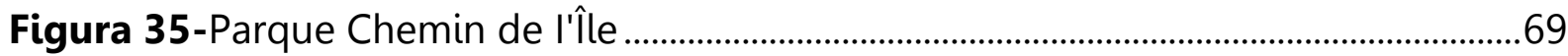

Figura 36- Alagado construído no Parque UT Gardens ....................................................71

Figura 37- Alagado construído no parque Chémim d' ÎLe.....................................................71

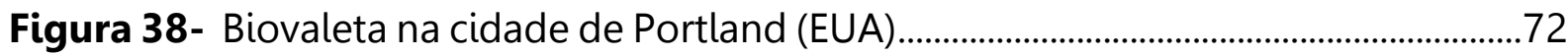

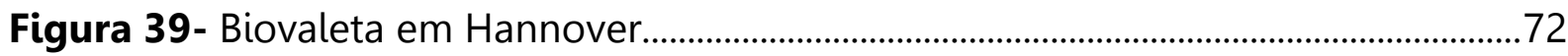

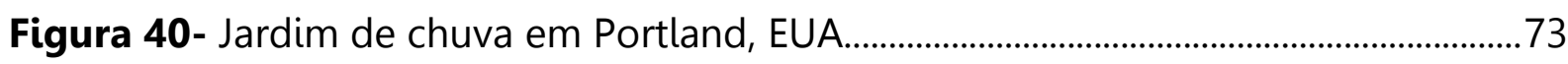

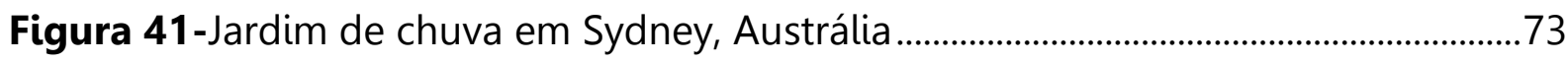

Figura 42-Canteiro em Moema, São Paulo (SP)......................................................................74

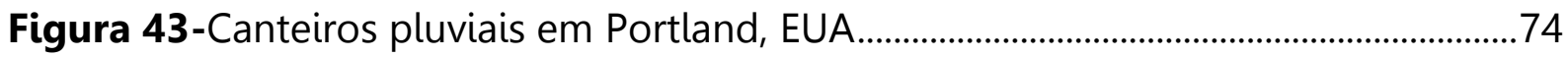

Figura 44- Unidades ambientais estruturais da metrópole de São Paulo ........................80

Figura 45- Parque Estadual da Cantareira nos municípios do Estado de São Paulo...82 Figura 46- Bacias hidrográficas na Zona de Amortecimento do Parque Estadual da Cantareira.

Figura 47-Bacia Hidrográfica do Tremembé/ Ribeirão Piqueri e indicação dos seus córregos abertos e ocultos. .86

Figura 48- Bacia Hidrográfica do Tremembé e suas sub bacias constituintes. .............85

Figura 49- Bacia Hidrográfica do Tremembé e seus principais córregos .85

Figura 50- Localização da área de estudo na Bacia Hidrográfica do Rio Tremembé/ Ribeirão Piqueri e nascente original do Rio Tremembé.

Figura 51- Localização da área de estudo com relação à Bacia Hidrográfica do Tremembé/ Ribeirão Piqueri e distritos da cidade de São Paulo (SP)................................87

Figura 52- Mapa das unidades naturais climáticas ..................................................................92

Figura 53- Mapa da distribuição da vegetação.........................................................................93

Figura 54- Mapa da vegetação significativa. ............................................................................94 
Figura 55- Vegetação significativa com base em imagens de satélite do Google Earth no ano de 2019

Figura 56- Parque Estadual da Cantareira a partir do Núcleo Pedra Grande..................96

Figura 57- Parque Horto Florestal...…………………………………………………....96

Figura 58- Parque Horto Florestal...…………………………………………………….....96

Figura 59- Possível localização da nascente na Rua João Miguel Ferreira.......................98

Figura 60- Visão da Rua João Miguel Ferreira na possível localização da nascente. ..98

Figura 61- O curso do Tremembé paralelo à Rua Travessa Francisco Iturri ...................98

Figura 62- Vista a partir da Rua José Bergamini: a proximidade entre o curso do Rio Tremembé e edificações. 98

Figura 63- Rio Tremembé com lixo em suas margens a partir da Rua Professor Pedro Pedreschi

Figura 64- Rio Tremembé com margens concretadas a partir da Rua Raul de Morais Vítor.

Figura 65- Vista a partir da Rua João Nicolau Chamma: córrego esmaga sapo encontra-se confinado entre os muros

Figura 66- Vista a partir da Rua Arcanjo Cassiel: córrego Cantareira próximo a ocupações irregulares com presença de resíduos sólidos

Figura 67- Imagem Córrego IPESP a partir da Av. Vereador Ângelo Bôrtolo. 100

Figura 68- Imagem de um córrego sem denominação (contribuinte do Rio Tremembé) com calha em concreto. 100

Figura 69- Mapa hipsométrico. 101

Figura 70- Mapa da topografia que indica as declividades da região 101

Figura 71- Mapa geológico simplificado do Atlas Ambiental do Município de São Paulo 101

Figura 72- Seção Geológica da Serra da Cantareira................................................................105

Figura 73- Esboço Geológico da Região do Horto Florestal e Tremembé ................... 106 Figura 74- Mapa Sara Brasil de São Paulo com destaque para a área de estudo.... 107

Figura 75- Mapa das Unidades Climáticas. 110

Figura 76- Mapa das Ithas de Calor. 111

Figura 77- Zoneamento Ambeintal da área de estudo 
Figura 78- Rua da Estação em 1940, atual Rua Mamud Rahd, origem do bairro Tremembé

Figura 79- Rua da Estação em 1940, atual Rua Mamud Rahd, origem do bairro Tremembé

Figura 80- Proximidade do antigo Tramway da Cantareira e núcleos de povoamento.

Figura 81- Mapa da Região do Tremembé na década de 40 118

Figura 82- Três planos em 1950: a linha de trem na Rua São Cleto, Largo do Tremembé e a Igreja São Pedro

Figura 83- Vista do vale da Vila Rosa e a linha do Tramway, próximo à "Parada Santa" 118

Figura 84- Vista do Tremembé a partir da Av. Luiz Carlos Gentile de Laet. 119

Figura 85- Verde, concreto e nuvens azuis: uma harmonia típica do Tremembé. .119

Figura 86- Ocupação das margens do Rio Tremembé, trecho próximo à Rua Professor Pedro Pedreschi.

Figura 87- Ocupação das margens do Rio Tremembé- trecho localizado na Rua Agostinho Soares

Figura 88- Mapa das Macrozonas do Plano Diretor da cidade de São Paulo (2014)

Figura 89- Mapa das Macro áreas do Plano Diretor da cidade de São Paulo (2014)

Figura 90-Mapa do Uso e ocupação do solo. 124

Figura 91- Presença de residência de médio/ alto padrão na Rua Francisco Serrador

Figura 92- Vista de uma residência horizontal de baixo padrão a partir da Rua Predeschi.

Figura 93- Presença de residências de alto padrão na Rua Lair 124

Figura 94- Presença de residências de alto padrão na Rua Lair 125

Figura 95- Mapa do zoneamento da região 126

Figura 96- Mapa com indicação da classificação viária da região. 127 
Figura 97- Mapa de mobilidade da região . 128

Figura 98- Igreja São Pedro na Rua Amália Lopes de Azevedo ......................................... 129

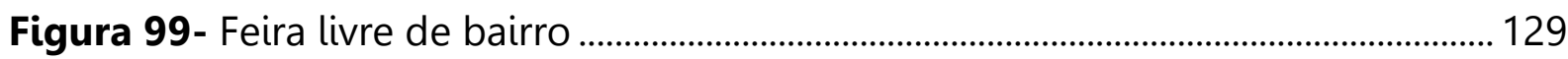

Figura 100- Parque Sena.................................................................................................. 138

Figura 101- Praça Antônio Arnoni....................................................................................... 129

Figura 102- Centro Atlético do Tremembé...................................................................... 130

Figura 103- Núcleo de recreação no Parque Horto Florestal ............................................ 130

Figura 104- Trecho do Rio Tremembé com destaque para o acúmulo de resíduos 138 Figura 105- Trecho do Rio Tremembé com destaque para o confinamento da calha e impermeabilização das encostas............................................................................................... 138

Figura 106- Rio Tremembé com galeria que lança efluentes no canal e indícios de assoreamento da margem oposta.

Figura 107- Marca d'água na parede como indício da ineficiência das infraestruturas

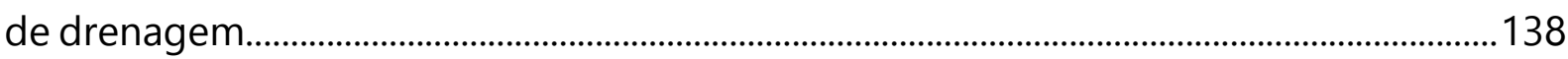

Figura 108- Localização dos reservatórios de detenção propostos na Bacia Hidrográfica do Tremembé

Figura 109- Localização prevista para o reservatório R1 .................................................. 140

Figura 110- Reservatório de detenção R1 ........................................................................ 140

Figura 111- Localização prevista para a implantação do reservatório de detenção R2

Figura 112- Local onde ocorrem as obras do reservatório R3 ………………………... 140

Figura 113- Obras do reservatório R3 na Rua Amália Lopes de Azevedo...................... 141

Figura 114- Obras do reservatório R3 na Rua Amália Lopes de Azevedo...................... 141

Figura 115- Localização prevista para a implantação do reservatório R2 na Rua São Cleto.

Figura 116- Vista do local previsto para a implantação do reservatório R2 a partir da Rua São Cleto

Figura 117- Localização prevista para implantação do reservatório R4. 142

Figura 118- Local previsto para implantação do reservatório R4. 142

Figura 119- Localização prevista para implantação do reservatório R5 na rua Florinda Barbosa.

Figura 120- Vista da rua Florinda Barbosa onde está previsto o reservatório R5..... 142 
Figura 121- Vista aérea no ano de 2016: localização prevista para a implantação do reservatório R6

Figura 122- Vista aérea no ano de 2016: localização prevista para a implantação do reservatório $\mathrm{R} 6$

Figura 123- Vista da Rua Natal de Queiroz. 150

Figura 124- Trechos do Rodoanel Mário Covas que circundam a Grande São Paulo 146

Figura 125- Rodoanel Mário Covas - Trecho Norte 147

Figura 126- Construção do Trecho Norte do Rodoanel Mário Covas na região da fazenda Santa Maria no distrito Tremembé. 148

Figura 127- Construção do Trecho Norte do Rodoanel Mário Covas na região da fazenda Santa Maria no distrito Tremembé 148

Figura 128- Mapa que indica o traçado do rodoanel na Zona de Amortecimento do Parque Estadual da Cantareira 153

Figura 129- Zoneamento urbano ambiental da área de estudo. 153

Figura 130- Diretrizes de infraestrutura verde para a área de estudo 161

Figura 131 - Diretrizes de infraestrutura verde para a área de estudo 162

Figura 132- Diretrizes de infraestrutura verde para a área de estudo 163

Figura 133- Diretrizes de infraestrutura verde para a área de estudo 164

Figura 134- Diretrizes de infraestrutura verde para a área de estudo 165

Figura 135- Diretrizes de infraestrutura verde para a área de estudo .166

Figura 136- Diretrizes de infraestrutura verde para a área de estudo 167

\section{LISTA DE TABELAS}

Tabela 1- Os dez princípios da infraestrutura verde 60

Tabela 2- Elementos e funções da Infraestrutura verde.

Tabela 3-Resumo das reportagens que apontam transtornos relacionados à drenagem em locais da Bacia Hidrográfica do Tremembé.

Tabela 4- Localização e volumes dos reservatórios propostos 139 


\section{SUMÁRIO}

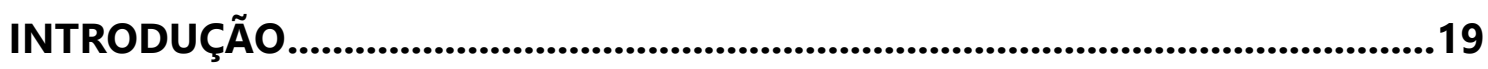

1 RELAÇÕES ENTRE NATUREZA, CIDADE E PAISAGEM ...............................26

1.1 Preceitos do Planejamento Ambiental.........................................................................2

1.2 O Planejamento Ambiental .........................................................................................32

1.3 A paisagem e os processos ecológicos …………………………………………….....34

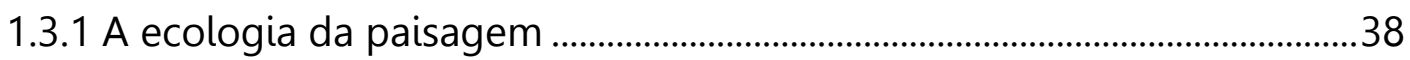

1.3.2 A paisagem a serviço da infraestrutura: algumas referências.....................41

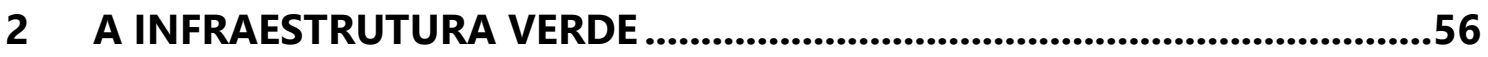

2.1 Origem e conceitos da infraestrutura verde ..........................................................56

2.2 Princípios da infraestrutura verde .........................................................................59

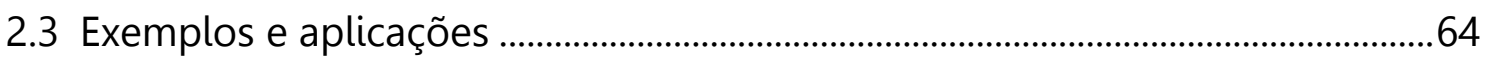

3 ANÁLISE TERRITORIAL DA PAISAGEM: CAMINHOS DO TREMEMBÉ .....78

3.1 A Serra da Cantareira como unidade ambiental estrutural da metrópole de

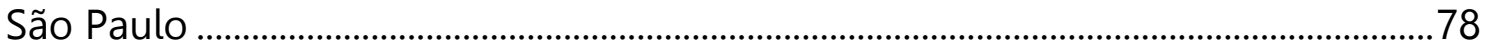

3.2 Justificativa e delimitação da área de estudo..............................................................83

3.3 Características físico ambientais.................................................................................89

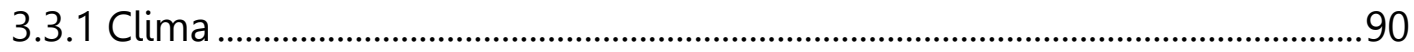

3.3.2 Cobertura Vegetal...........................................................................................92

3.3.3 Nascentes e cursos dágua...................................................................................97

3.3.4 Geomorfologia e compartimentação da paisagem.................................... 100

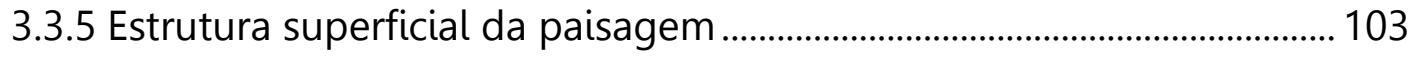

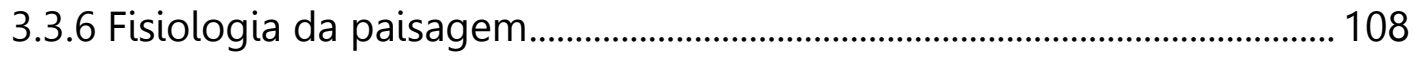

3.3.7 Zoneamento ambiental: potencialidades naturais e funções ambientais da área de estudo 
3.4 Características morfológicas e urbanas da área .................................................. 116

3.4.1 Histórico da ocupação.................................................................................... 116

3.4.2 Usos e ocupação territorial............................................................................... 120

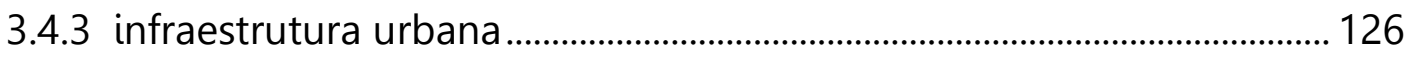

4 AS INFRAESTRUTURAS URBANAS TRADICIONAIS........................... 131

4.1 Alterações na dinâmica da paisagem: planos e projetos urbanos previstos para a área de estudo e entorno

4.1.10bra de contenção de enchentes na Bacia Hidrográfica do Tremembé

4.1.2 Os reservatórios de detenção e seus legados para paisagem

4.1.3 Obra do Trecho Norte do Rodoanel Mário Covas 145

5 APLICAÇÃO DA INFRAESTRUTURA VERDE...................................... 152

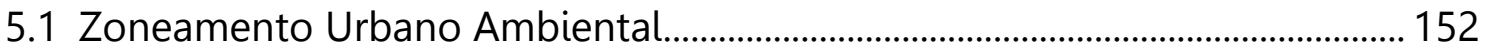

5.2 Diretrizes de infraestrutura verde para a área de estudo .................................. 156

CONSIDERAÇÕES FINAIS ........................................................................ 168

REFERÊNCIAS BIBLIOGRÁFICAS ................................................................... 171 


\section{INTRODUÇÃO}

A natureza sempre esteve presente nos aglomerados urbanos. Nas cidades atuais, essa força natural recebe forças externas cada vez maiores originadas a partir de práticas e atividades humanas. O resultado dessas influências, exercidas em grande parte de maneira irresponsável, podem ser reconhecidas por meio de alterações na dinâmica do ar, formação de ilhas de calor, erosão da terra ou mudanças no ciclo hidrológico. Ao longo de muito tempo a evolução humana moldou o mundo natural de acordo com seus próprios interesses e, em paralelo, consolidou uma forte tradição que subestima os benefícios que a natureza é capaz de ofertar às cidades.

O descompasso entre as necessidades humanas e as questões ambientais já perdura por anos. No contexto global, a expansão urbana das cidades foi pautada sobretudo na cultura do uso de veículos automotores e na especulação imobiliária, carecendo de intervenções urbanas que garantissem a integridade da paisagem natural, com efeitos na sua capacidade de suporte muitas das vezes irreversíveis. O resultado deste tipo de desenvolvimento implica em graves consequências, com impactos que interferem também a qualidade de vida das pessoas que habitam esses espaços.

A paisagem natural de muitas cidades foi drasticamente alterada cedendo mais espaço para as áreas urbanizadas. Os corpos d'água, tidos como um impasse ao desenvolvimento, foram em grande parte modificados como forma de permitir a implantação do sistema de infraestrutura e circulação viária, ofuscados por tamponamentos e canalizações. Quando mantidas a céu aberto, as águas foram alvo de poluentes e ocupações irregulares e, em adicional, as margens de seus cursos foram concretadas. Diante disto, os rios e córregos perderam, além de sua morfologia original, sua função e identidade.

Aliado ao problema da degradação dos corpos hídricos, o crescimento urbano implicou em uma alta perda de áreas vegetadas com impactos no sistema hidrológico natural. As áreas impermeáveis, além de contribuírem para o 
aquecimento dos espaços, diminuem a capacidade que a paisagem possui de infiltrar e armazenar a água da chuva com o aumento da velocidade de escoamento o volume de poluentes transportados para os córregos, rios e recursos hídricos subterrâneos. Todo esse processo contribui para degradação ambiental desses espaços, inviabilizando a recuperação da paisagem e seus processos ecológicos.

Os efeitos negativos de uma linha de planejamento que subjuga a natureza podem ser facilmente identificados na cidade de São Paulo. O município é formado por um modelo de urbanização que privilegiou a ocupação das suas planícies aluviais, canalização dos rios e córregos e intenso processo de alteração do solo com impermeabilização das áreas vegetadas. Alteração do ciclo hidrológico, elevação das temperaturas e sobrecarga do sistema de drenagem são alguns dos problemas presentes na metrópole brasileira. Em acréscimo, esse cenário desanimador tende a piorar de acordo com as pesquisas. Estudos preliminares realizados pelo Instituto Nacional de Pesquisas Espaciais (Inpe) indicam, uma elevação média de $2^{\circ}$ a $3^{\circ} \mathrm{C}$ na temperatura na Região Metropolitana entre anos de 2070 e 2100, o que poderá dobrar o número de dias com chuvas intensas.

Recentemente, no dia 10 de fevereiro de 2020, a cidade vivenciou um episódio assustador e que vai entrar para a história. Em apenas uma madrugada, município recebeu uma quantidade de chuva equivalente a $66 \%$ do total esperado para todo o mês de fevereiro. Após a chuva torrencial, foram identificados mais de 78 pontos de alagamentos registrados pelo Centro de Gerenciamento de Emergências Climáticas (CGE) além de casos de deslizamentos e transbordamento dos Rios Pinheiros e Tietê, deixando as marginais intrafegáveis. A cidade mais importante do Brasil foi obrigada a parar em plena segunda-feira, refém das condições climáticas impostas e do baixo desempenho do seu sistema de drenagem. 
Casos como este nos obrigam a repensar a capacidade de resiliência ${ }^{1}$ do modelo de urbanização vigente. Mesmo diante de casos como este, o modo de expansão das cidades continua sustentado pela alteração radical do sistema hídrico e ocupação de suas várzeas, desmatamentos, impermeabilizações e artifícios que atuam como medidas estanques diante dos enormes riscos que as mudanças climáticas oferecem. De que maneira as cidades estão lidando para combater este cenário pautado em incertezas e vulnerabilidades? Devemos continuar adotando práticas que negligenciam os sistemas naturais responsáveis por oferecer serviços ambientais de extrema importância para a qualidade urbana ambiental e bem-estar dos seres humanos?

Nos últimos anos, tomou-se como desafio mundial uma mudança na forma de pensar aspectos da cidade e seu funcionamento, tida não mais como uma conformação de seguimentos que anulam a ambiência nativa, mas agora planejada como uma rede que interliga, agrega, considera e respeita suas particularidades e princípios naturais. Sob luz dessa nova perspectiva, surge um tipo de ferramental de planejamento ambiental que defende práticas de conservação associadas ao planejamento da infraestrutura e do desenvolvimento, denominada infraestrutura verde.

Considerada como uma resposta ao paradigma de incertezas enfrentado pelas cidades modernas, a infraestrutura verde emerge como um instrumento cuja base é a oferta de serviços ecológicos em ambientes construídos, de maneira que viabilize o desenvolvimento urbano em consonância com a capacidade de suporte dos seus ecossistemas. Definida como uma rede interconectada de áreas naturais e outras áreas livres, parte de uma visão sistêmica da paisagem propondo a transformação de áreas impermeabilizadas em espaços com múltiplas funções capazes de oferecer benefícios às esferas ambientais, sociais e econômicas.

Quanto aos possíveis benefícios desempenhados no âmbito ambiental, a infraestrutura verde atua na regulação do sistema pluvial com prevenção de

\footnotetext{
${ }^{1}$ Resiliência é a capacidade de um sistema para absorver perturbações e ainda manter sua função básica e estrutura (NEWMAN; BEATLEY; BOYER, 2009).
} 
inundações e deslizamentos durante eventos extremos de chuvas, realiza a filtragem de poluentes químicos e sedimentos oriundos do escoamento, proporciona melhoria do microclima, oferta de habitat para plantas e vida selvagem, conservação da natureza, purificação das águas e do ar, criação de zonas para exercício e atividades recreativas, entre outros (BENEDICT; MC MAHON, 2006).

Diante da potencialidade desse tipo de ferramenta no campo do planejamento, o trabalho elegeu uma área de estudo localizada na cidade de São Paulo para sua investigação e aplicação.

Para a determinação da área de estudo foi tomado como eixo linear o curso do Rio Tremembé, considerado o rio principal da bacia hidrográfica do Rio Tremembé/ Ribeirão Piqueri, desde sua nascente original situada nas bordas da Serra da Cantareira até alcançar a divisa com o distrito Jaçanã. Esse percurso linear compreende o alto e médio curso do rio Tremembé e se expande por uma faixa de 500 metros para cada um dos lados formando uma área de influência chamada de zona de amortecimento ou buffer zone. Esta extensão foi escolhida como área de estudo pois se manifesta como intrigante oportunidade de pesquisa relacionada com sua qualidade urbana ambiental.

Apesar de já ser formada por bairros consolidados, a região abriga grandes áreas vegetadas, fragmentos remanescentes da Mata Atlântica, afloramento de alguns trechos do rio e córregos e proximidade com a matriz ecológica da Serra da Cantareira, o que the concede grande interesse como área de estudo no campo da ecologia da paisagem. A área é alvo para a construção de uma obra de drenagem com o objetivo de mitigar enchentes, alagamentos e outros transtornos causados aos moradores, o que também realça a sua importância como uma região propensa a receber princípios da infraestrutura verde.

Além disso, trata-se de uma área que abrange parte da Zona de Amortecimento do Parque Estadual da Cantareira com repercussões no âmbito paisagístico e ambiental. A grande motivação dessa pesquisa se encontra, portanto, na intenção de fazer aflorar este potencial possibilitando a conciliação entre as características naturais da paisagem e seus elementos urbanos, 
colaborando assim para a formação de espaços mais resilientes e otimização da qualidade de vida dos moradores da região.

Como objetivo geral desta pesquisa aponta-se estudar a infraestrutura verde, embasada nos princípios do desenho ambiental e da ecologia da paisagem e analisar sua aplicabilidade no alto e médio curso do Rio Tremembé em São Paulo (SP). Como objetivos específicos estão conhecer a relação entre os conceitos de planejamento ambiental, ecologia da paisagem e infraestrutura verde; explorar os conceitos, princípios e exemplos da infraestrutura verde; analisar a estrutura ambiental e urbana da área de estudo por meio da aplicação do método do zoneamento ambiental desenvolvido pelo autor Guilherme Schutzer; oferecer um panorama das últimas intervenções urbanas executadas na região e seus efeitos na dinâmica da paisagem e, por fim, propor diretrizes de infraestrutura verde a partir das particularidades da área que auxiliem na conformação de espaços mais resilientes.

Este trabalho foi dividido em três seções que se ramificam ao longo de cinco capítulos. A primeira seção aborda o referencial teórico da pesquisa, com apresentação e esclarecimento dos conceitos pertinentes ao seu entendimento. A segunda parte será voltada para uma análise aprofundada da área de estudo e suas recentes intervenções urbanas realizadas. Na sequência, a última seção apresenta as diretrizes de infraestrutura verde aplicadas ao local.

O primeiro capítulo oferece um breve panorama histórico a respeito de intervenções nas paisagens aliadas às dinâmicas da natureza desde o século XIX, a partir das influências de arquitetos paisagistas da época. O retrospecto avança até os fundamentos do planejamento ambiental e ecologia da paisagem, englobando ainda referências de projetos realizados que admitiram paisagem natural enquanto parte importante da infraestrutura das cidades.

O capítulo dois esclarece o tema central da dissertação, a infraestrutura verde como ferramenta de planejamento, com enfoque no campo ambiental. Serão abordadas suas definições além da apresentação dos seus princípios com destaque para aspectos da conectividade e multifuncionalidade. Ao final, este capítulo oferece exemplos de aplicação da infraestrutura verde em diferentes 
escalas seja em localidades maiores, por meio de planos municipais, ou em espaços menores, com elementos implantados nas vias locais.

O capítulo três apresenta um panorama da área de estudo com a identificação das relações estabelecidas entre suas dinâmicas físicas e ambientais. Serão estudados os aspectos relativos ao clima, vegetação, recursos hídricos e de que forma se revelam ao longo da geomorfologia, estrutura e fisiologia da paisagem. O resultado dessa análise será expresso pela delimitação do zoneamento ambiental, método apresentado e desenvolvido pelo geógrafo José Guilherme Schutzer no seu livro "Cidade de Meio Ambiente". Ainda neste mesmo capítulo é apresentada uma análise da forma urbana da área de estudo descrevendo aspectos relacionados à infraestrutura urbana, uso do solo e ocupação.

O capítulo quatro apresenta algumas críticas a respeito dos tipos de infraestruturas tradicionais adotados nas cidades e seus impactos negativos na paisagem natural desses espaços. A análise se aplica também à duas obras em andamento nomeadas "Obra de contenção de enchentes na Bacia Hidrográfica do Tremembé" e "Obra do Trecho Norte do Rodoanel Mário Covas", ambas com efeitos nas dinâmicas da paisagem da área de estudo e seu entorno.

O capítulo cinco conclui o estudo desenvolvido neste trabalho, apresentando as diretrizes de infraestrutura verde para a área que engloba o alto e médio curso do Rio Tremembé. As recomendações adotam como base os conceitos e princípios da infraestrutura verde associadas às dinâmicas naturais e urbanas da área de enfoque. 
INFRAESTRUTURA VERDE APLICADA AO ALTO E MÉDIO CURSO DO RIO TREMEMBPE I SEÇÃO | REFERENCIAL TEÓRICO 


\section{CAPÍTULO 1}

\section{RELAÇÕES ENTRE NATUREZA, CIDADE E PAISAGEM}

"A cidade precisa ser reconhecida como parte da natureza e ser projetada de acordo com isso (...). A natureza na cidade precisa ser cultivada como um jardim, em vez de ser ignorada ou subjugada" (SPIRN, 1995, p.21).

Desde o surgimento das primeiras civilizações humanas a natureza recebe os mais diversos tipos de influências. As necessidades humanas e as questões ambientais que delas originam ocorrem há milhares de anos, sendo tão remotas quanto a mais antiga das cidades, repetidas a cada geração (SPIRN, 1995).

No campo das ciências de engenharia e arquitetura, as modificações no meio natural passaram a ganhar mais força a partir do surgimento das primeiras construções feitas pelos homens - elaboradas inicialmente com a necessidade de garantir moradia ou refúgio. Naquela época, além de realizar modificações no terreno natural em prol do seu abrigo, o homem já utilizava a natureza a favor de suas técnicas construtivas rudimentares.

Diante do desenvolvimento dos assentamentos e posterior surgimento das cidades, a evolução das técnicas construtivas somada às gradativas interferências humanas no meio natural trouxe à tona formas de expressar e pensar as relações entre os conceitos de natureza, cidade e paisagem.

Spirn (1995) define a natureza como força natural que sempre esteve presente muito antes da civilização, em seguida permeando a cidade e estabelecendo relações entre o ar, o solo, a água e organismos vivos em seu interior e a sua volta. A mesma autora aponta que essa força natural, quando reconhecida e aproveitada, representa um recurso que colabora para a formação de um habitat benéfico. 
A paisagem, por sua vez, implica na totalidade das forças da natureza somadas às interferências humanas e sua cultura, podendo expressar-se por meio de recursos visíveis como campos, colinas, florestas e corpos d'água. Tida como a interface entre os processos humanos e naturais, a paisagem está em constante processo de transformação, às vezes em sintonia com os processos naturais, outras vezes alterando-os (NDUBISI, 2002). De acordo com Laurie (1978), a paisagem consiste no estudo da terra sob a perspectiva das suas características fisiográficas e ambientais e assume diferentes configurações conforme o impacto das atividades humanas ao longo da história. Nessa direção, o autor conceitua a paisagem como um reflexo dos sistemas dinâmicos que envolvem os aspectos naturais e sociais de um determinado espaço.

Os primeiros registros sobre o planejamento do espaço apontam que os vilarejos eram pensados para a prática da pesca ou agricultura além de que determinavam a organização do seu território segundo aspectos ambientais como topografia e microclima (SANTOS, 2004). Esse tipo de ordenamento da paisagem racional voltado para fins agrícolas e sociais teve seu início desde as primeiras civilizações. Como exemplos que retratam a manipulação consciente da paisagem pelo homem é possível citar: os terraços de arroz na China, as pirâmides, templos e jardins domésticos no Egito bem como o sistema de drenagem dos canais para a irrigação dos campos agrícolas na Mesopotâmia (LAURIE, 1978).

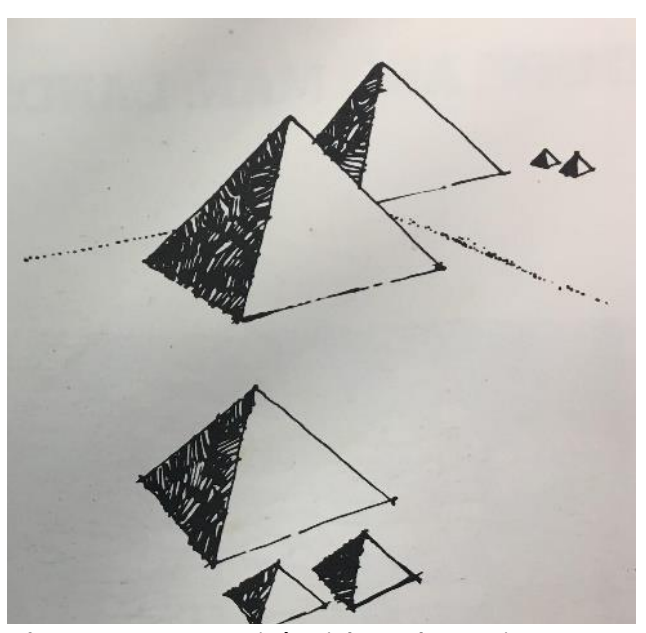

Figura 1- As pirâmides do Egito: uma reflexão da crescente autoconfiança do homem na natureza. Fonte: LAURIE, 1978.

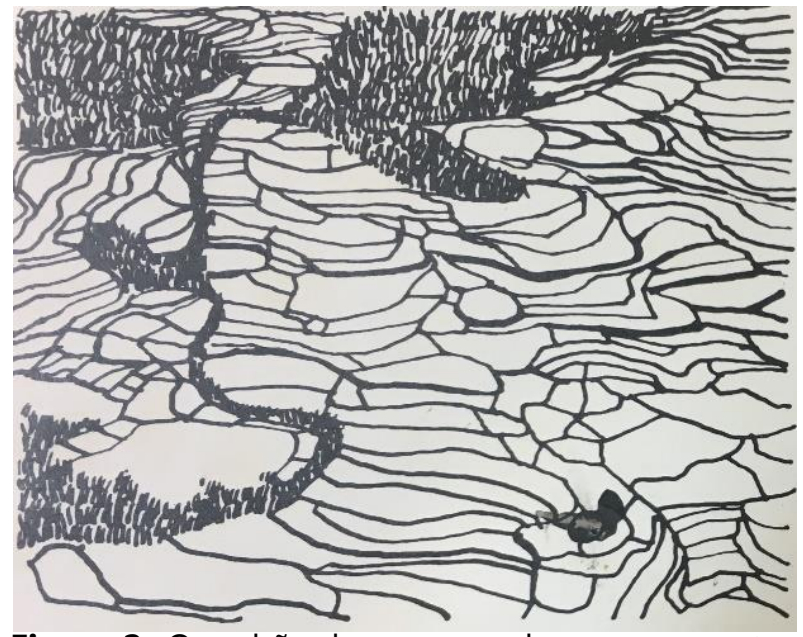

Figura 2- O padrão dos campos de arroz presentes na China ilustra a relação entre o homem e a natureza. Fonte: LAURIE, 1978. 
Durante este período de formação ainda dos primeiros assentamentos, a organização do espaço pelo homem era guiada sobretudo pelos serviços naturais que paisagem poderia oferecer. A produtividade da terra, tida como prioridade, oscilava de acordo com aspectos como fertilidade do solo e a conservação nutrientes, por exemplo. Esse tipo de dependência fez com que a população priorizasse cada vez mais os benefícios que determinada terra poderia oferecer garantindo a sua sobrevivência e sustento. Diante disto, uma espécie de relação simbiótica entre terra e assentamento dominou a vida naquele tempo, dando forma física às primeiras cidades e à sua paisagem circundante (HOUGH, 1984).

Com o passar dos anos e diante da forma com que se deu a formação e consolidação das cidades já no período industrial, o vínculo entre os assentamentos humanos e a natureza foi perdendo força em prol da realização de outras atividades humanas. Intervenções na busca por obter quesitos como segurança, abrigo, alimento, água, energia, meios de circulação e a constante demanda por espaço são exemplos de necessidades comuns às cidades e que impactaram o meio natural com exploração e desperdício de recursos naturais (SPIRN, 1995).

Em face dessas transformações, seja devido às dinâmicas sociais ou crescimento econômico vigentes, o elo existente entre cidade e o meio natural imerso na paisagem foi perdendo espaço para as construções dos centros urbanos. A ascensão desses novos espaços, centrados na força do mercado, alta tecnologia, trocas de matéria e energia afastou o homem da dimensão ecológica culminando na geração problemas ambientais urbanos (HOUGH, 1984; ODUM, 1988). Como bem relata Franco (2000, p. 21): "diante da especulação financeira e imobiliária, a cidade foi se transformando em um joguete de interesses sob o domínio de empresas e proprietários que passaram a moldá-la e readequá-la de acordo com suas próprias preferências".

A cidade é, portanto, a transformação da natureza pelos seres humanos para servir às suas necessidades. A maneira de gerir o meio urbano desassociado da natureza ou até contrário a ela dominou a maneira de como o conceito de cidade foi concebido ao longo do tempo e interferiu também o modo como ela foi 
construída. Em decorrência desta não integração com os preceitos naturais, os problemas ambientais urbanos se revelaram ao longo do tempo por meio das águas e ar poluídos, da escassez de recursos, do aumento da frequência enchentes, dos elevados custos relativos à energia e construção, dentre tantos outros (SPIRN,1995).

Os efeitos causados por estes impactos ambientais trouxeram à tona, a partir da do século XIX, muitas reflexões em torno da temática do planejamento e sua possível concordância com os recursos naturais disponíveis. Essas ideias partiram de pensadores visionários que tinham o intuito de fazer um alarme sobre os efeitos dos abusos humanos na paisagem.

\subsection{PRECEITOS DO PLANEJAMENTO AMBIENTAL}

O reconhecimento dos efeitos das intervenções humanas na natureza e a importância de conservá-la teve início como uma reação à Revolução Industrial. As propostas baseadas na conservação da terra e preservação dos recursos naturais admitiram suas raízes no século XIX por meio de pensadores como John Rushin, na Inglaterra, Viollet- Le Duc na França e Henry David Thoureau, Frederick Law Olmsted, George Perkins Marsh nos Estados Unidos. Em uma época em que princípios do positivismo e liberalismo econômico eram impostos, os ideais destes homens iam totalmente contra a mentalidade vigente ao mesmo tempo que revelavam uma incrível previsão do futuro (FRANCO,2000, p.19).

Os esforços advindos destes visionários influenciaram o pensamento de outros pensadores, que passaram a transmitir a partir de seus planos o conceito de natureza como um elemento valioso presente a paisagem. Entre os profissionais inspirados, cita-se arquiteto paisagista Frederick Law Olmsted o qual absorveu como filosofia dos seus projetos o entendimento da natureza como fonte de cura espiritual- concepção estabelecida primeiramente por Thoureau. Nessa direção, Olmsted ressaltava que a paisagem deveria ser analisada sob essa mesma perspectiva ecológica, enfatizando os efeitos 
restaurativos dos espaços livres na saúde física e mental das pessoas. (MENEGUETTI, 2009; HERZOG, 2013).

Os efeitos das relações entre cidade- natureza frente os avanços das cidades também ficaram evidentes na Inglaterra quando Ebenezer Howard apresentou o conceito das "cidades- jardins", tendo como concepção o estabelecimento de limites físicos e demográficos associados aos espaços livres verdes. As cidadesjardim eram direcionadas à crescente população urbana e tinha como intensão proporcionar o equilíbrio entre o meio urbano e a natureza. O modelo de cidade proposto teria baixa densidade e considerava o espaço verde como elemento estruturador do espaço urbano, na forma de cinturões verdes de áreas naturais e agricultáveis, florestas, pomares e bosques (MENEGUETTI,2009; TARDIM, 2008).

No ano de 1920 Aldo Leopold reforça este mesmo ideal nos Estados Unidos e propõe o planejamento da paisagem a partir de um conhecimento holístico da cidade introduzindo o conceito de paisagem como um organismo vivo (Leitão e Aern, 2002). Aldo Leopold lançou as bases éticas que governavam as relações entre os seres humanos e a natureza defendendo que a prática desta moral faria com que os homens preservassem a integridade, estabilidade e beleza dos sistemas naturais (FRANCO, 2000).

O reconhecimento da importância da natureza nos planos urbanos foi se dando de maneira diferente ao longo do tempo. Nessa linha destacam-se o Plano de Albercrobie em Londres (1943), o Copenhagen Finger Plan (1947) e o Plano Regional de Estocolmo (1967) que, juntos, apresentavam o espaço verde como um componente estruturador do espaço urbano. No entanto, esses mesmos planos admitiam a natureza principalmente como forma de oferecer o lazer ou atender padrões estéticos. O fato é que grande parte dos planos de caráter territorial elaborados no século XX foram baseados nas visões em grande parte positivistas e progressistas, visando o desenvolvimento econômico e o crescimento ilimitado (FRANCO,2001; VASCONCELLOS, 2015).

Na segunda metade do século XX, período após a Segunda Guerra Mundial e durante a Guerra do Vietnã, a dimensão da crise ambiental foi de fato identificada. Essa preocupação se deu principalmente devido uma melhor 
compreensão das interações entre as pessoas e a paisagem, fruto do surgimento de atividades em todo mundo nas áreas de proteção ambiental e gestão de recursos bem como crescente conscientização pública diante das consequências negativas das ações humanas nas paisagens naturais e culturais (FRANCO, 1997; NDUBISI, 2002).

O aumento da consciência ambiental neste período resultou na ascensão de movimentos ambientalistas e significativa evolução na teoria e nos métodos de planejamento da paisagem. No contexto dos Estados Unidos, a elaboração de planos paisagísticos baseados na visão pitoresca ou no racionalismo pôde ser de fato rompida em 1969 após a aprovação do Nacional Environmental Policy Act $(\mathrm{NEPA})^{2}$, política nacional baseada na visão conservacionista e que incentivou o uso de informações ecológicas no planejamento. A partir disto, inicia-se uma linha de atuação de arquitetos paisagistas baseada nos preceitos da ecologia tendo a influência de arquitetos como McHarg e Lawrence Halprin (FRANCO, 1997).

Em meados dos anos 1960 Mcharg foi referência em planejamento urbano a partir da análise de aspectos abióticos, bióticos e culturais em planos de nível regional, com enfoque na minimização dos impactos sobre os recursos naturais Seu trabalho na arquitetura da paisagem e no planejamento regional tratava a ecologia como suas ciências fundamentais e, baseado nisto, divulgou em 1969 o método Suitability Analysis conhecido como "Análise da adequação" no qual aborda a importância da biologia como embasamento do planejamento e projeto. Já Lawrence Halprin se destacou por meio da sua atuação em trabalhos ambientais de participação comunitária e foi um dos primeiros paisagistas a tratar o projeto dos espaços públicos no conceito de "Qualidade Ambiental Urbana" (FRANCO, 1997; MENEGUETTI,2009).

Ambos arquitetos paisagistas tomaram como referência o trabalho de Eugene. Odum, Fundamentals of Ecology (Fundamentos da Ecologia) publicado no ano de 1953. Os conceitos abordados na obra, relacionados aos ecossistemas,

\footnotetext{
${ }^{2}$ NEPA- Nacional Environmental Policy Act- Política Nacional do Meio Ambiente, criada em 1969 nos Estados Unidos.
} 
ciclos biogeoquímicos e energia dos sistemas ecológicos, revolucionou o método de abordagem do planejamento urbano e regional culminando em uma nova linha de trabalho desempenhada por arquitetos e paisagistas. Esta linha de planejamento surgiu orientada para as intervenções humanas dentro da capacidade de suporte dos ecossistemas e foi denominada como Planejamento Ambiental (FRANCO, 1997).

\subsection{O PLANEJAMENTO AMBIENTAL}

A preocupação com o meio ambiente e os recursos naturais só foi ganhando mais força no mundo como um todo na transição entre a década de 1980 e 1990 com a oficialização do termo "desenvolvimento sustentávelem 1987 fruto de uma comissão pelo Programa de Meio Ambiente das Nações Unidas. Após a comissão, o então intitulado relatório Our common future (Nosso futuro comum) ou "Relatório de Brundtland" divulgou uma listagem de problemas críticos do meio ambiente relacionados com o desenvolvimento do planeta, entre eles: aumento da erosão do solo, desaparecimento de florestas, aumento da poluição do ar e toxidade dos resíduos produzidos (FRANCO, 2000; VASCONCELLOS, 2015).

Nessa perspectiva, o relatório confirmava que as ações antrópicas estavam de fato interferindo na qualidade dos sistemas naturais do planeta transformado significativamente aspectos da atmosfera, solos, água, fauna e flora. Como uma resposta à estes conflitos e à uma competição cada vez mais acirrada por terras, água, recursos energéticos e biológicos surge então a vertente de planejamento intitulada Planejamento Ambiental, conforme define FRANCO (2000, p.35):

Assim pode-se considerar que Planejamento Ambiental é todo o planejamento que parte do princípio da valorização e conservação das bases naturais de um dado território como base

\footnotetext{
${ }^{3}$ Termo que declarava o meio ambiente como um autêntico limite de crescimento, propondo que se deveria atender às necessidades do presente sem comprometer $\mathrm{o}$ atendimento às gerações futuras (SANTOS,2004).
} 
de auto sustentação da vida e das interações que a mantém, ou seja, das relações ecossistêmicas. Para isso, o Planejamento Ambiental emprega como instrumentos todas as informações disponíveis sobre a área de estudo, vindas das mais diversas áreas do conhecimento, bem como as tecnologias de ponta que possam facilitar o seu meio principal de comunicação e de projeto que é o Desenho Ambiental

Os objetivos desse tipo de planejamento vão ao encontro das premissas do Desenvolvimento Sustentável da sociedade e das suas atividades incluindo as cidades e suas redes urbanas e exigindo uma abordagem holística e multidisciplinar. Nos anos 1980 expressão "planejamento ambiental" era reconhecida como um planejamento aplicado à uma área com o propósito de "relacionar informações, diagnosticar o ambiente, prever ações e normatizar seu uso através de uma linha ética de desenvolvimento" (SANTOS, 2000, p.27).

O Planejamento Ambiental tem o papel de formar relações entre os sistemas ecológicos e os processos da sociedade englobando suas atividades relacionadas à cultura, meio ambiente e economia de maneira a garantir a qualidade desses componentes. Fundamentado sobretudo na ética ecológica, baseia-se em intervenções que proporcionem a possibilidade de vidas e civilizações futuras considerando a capacidade de sustentação dos ecossistemas em diferentes níveis seja local, regional, continental e planetária (FRANCO, 2000; SANTOS, 2000).

Santos (2002, p.28) afirma que, de uma forma geral, o planejamento ambiental consiste "na adequação de ações à potencialidade, vocação local e à sua capacidade de suporte, buscando o desenvolvimento harmônico da região e a manutenção da qualidade do ambiente físico, biológico e social". A autora acrescenta que esse tipo de planejamento deve prever e apontar transformações no uso da terra bem como indicar quando explorar fontes seguras e aceitas para comunidades no âmbito local e regional.

Ainda em meados da década de 80, a partir de uma mentalidade de proteção ambiental já consolidada, trabalhos dos autores Michael Hough, Anne Spirn e John Lyle trataram de princípios ecológicos do planejamento voltados à 
paisagem urbana, com estudos voltados para a ecologia na cidade e as relações do meio natural com o meio construído (PELLEGRINO, 2000; HERZOG, 2013).

Ao longo do tempo, a preocupação de se aproximar a disciplina da ecologia com as vertentes do planejamento urbano foi se intensificando. As novas intervenções na paisagem impulsionaram outros modos de colaboração entre os paisagistas e cientistas que tratam da natureza e de seus espaços e de como esse conhecimento ecológico poderia ser melhor aproveitado nos planos e projetos dos campos e das cidades (PELLEGRINO, 2017).

\subsection{A PAISAGEM E OS PROCESSOS ECOLÓGICOS}

"A dependência existente entre os sistemas vivos, que interconectam o desenvolvimento dos processos físicos e vitais da terra, o clima, a água, as plantas e os animais, a contínua transformação e a reciclagem dos materiais vivos e não vivos são os elementos que propiciam a autossuficiência da biosfera, que permitem a vida na Terra e que dão lugar à paisagem física (HOUGH, 1998, p.5).

A aproximação entre o planejamento da paisagem e a natureza teve seu espaço em meados do século XIX por meio de pensadores influentes, como mencionado anteriormente. No entanto, somente a partir da década de 60 o fortalecimento da consciência de que era necessário agregar os valores ambientais ao planejamento do território foi de fato fortalecida (HOUGH, 1984).

A partir deste momento, foi se adquirindo uma melhor compreensão por estudiosos acerca da importância de se reconhecer os processos ecológicos enquanto base fundamental para o planejamento da paisagem. Essa associação entre os conceitos ecológicos e planejamento foi impulsionada diante da melhor compreensão do conceito de ecossistema e como este poderia ser utilizado de maneira a guiar o diálogo entre as ações humanas e os processos naturais (HOUGH, 1984; MENEGUETTI,2009). Essa temática foi discutida e trabalhada por 
muitos profissionais dentre os quais se é possível citar Augus Hills, Philip Lewis, Ian McHarg e Eugene Odum.

Hills era cientista e geógrafo que, junto a demais colegas na cidade de Toronto, desenvolveu uma metodologia que utilizava capacidades biológicas e físicas para orientar as decisões de uso da terra nas atividades de agricultura, silvicultura, fauna e recreação enquanto Philip Lewis era arquiteto paisagista e deu enfoque nas características perceptivas da paisagem.

Este último criou um método de análise direcionado para os corredores ecológicos situado no Estado de Wisconsin, nos Estados Unidos, intitulado "Estudo do Corredor de Qualidade de Wisconsin". Nesse estudo, Lewis constatou que os recursos perceptivos na região eram as águas superficiais, zonas úmidas e topografia significativa e que estes mesmos elementos deveriam estar conectados formando um padrão linear intitulado "corredor ambiental". Sua metodologia impulsionou novas abordagens em torno da qualidade perceptiva da paisagem e sua ligação com as características ambientais, uma aproximação até então pouco discutida (NBUBISI, 2002).

A partir dos anos 1960, o então arquiteto paisagista e professor McHarg ganha bastante notoriedade por defender fortemente o emprego da ecologia como base essencial e capaz de possibilitar relações positivas entre o uso humano e os recursos da paisagem. Bastante influenciado pelas obras de Patrick Geddes e Mumford, Mc Harg desenvolveu o método suitability analysis (análise da adequação) que vinculava a ecologia ao planejamento da paisagem partindo do princípio de que todo lugar é a soma de seus processos históricos, físicos e bilógicos. Quanto às técnicas adotadas, trabalhava com a sobreposição de mapas geológicos, hidrológicos, topográficos e do uso e ocupação do solo em acetato transparente e, a partir dessa justaposição, identificava as áreas adequadas aos diferentes usos humanos (NBUBISI, 2002). 


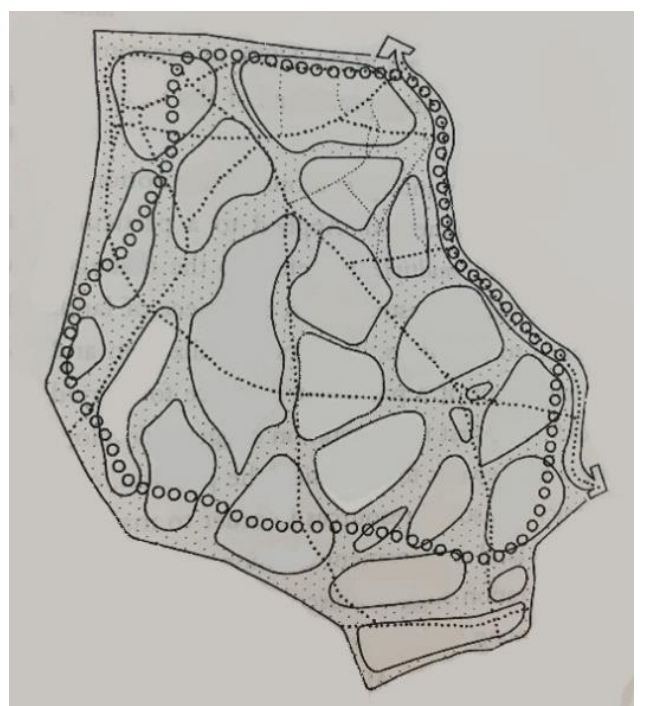

Figura 3- Desenho que representa o estudo de qualidade para Wisconsin vinculando qualidades visuais às características ambientais naturais da paisagem. Philip Lewis delimitou água, áre zonas úmidas e padrões significativos de topografia que compõem os chamados corredores ambientais. Fonte: NBUBISI. (2002).

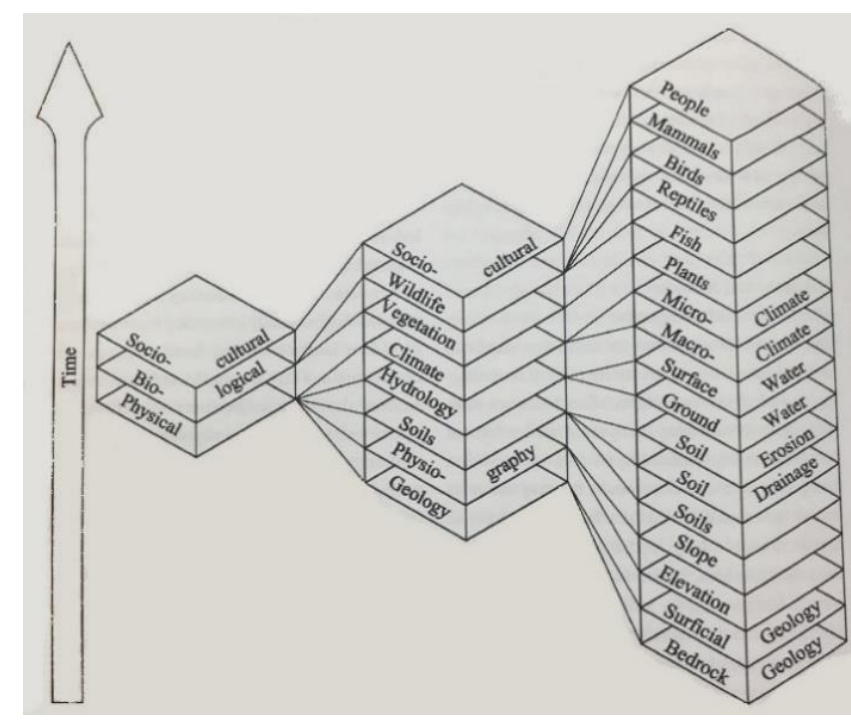

Figura 4- O modelo "Bolo em camadas" apresentado por McHarg representa as relações entre os elementos abióticos, bióticos e culturais de uma paisagem. Os elementos são mapeados e sobrepostos para revelar áreas da paisagem adequadas para diferentes atividades humanas. Fonte: NBUBISI (2002).

Métodos como esses anteriormente expostos interpretavam a paisagem como unidade produtiva e dependente dos princípios ecológicos vigentes passando a se aproximar de outras disciplinas relacionadas à ecologia. Por conseguinte, estudos ecológicos passaram a interpretar a função das paisagens em seus trabalhos de diversas formas, impulsionados pelo entendimento do conceito de ecossistema e de que maneira este último poderia mediar uma relação benéfica entre as ações humanas e os processos naturais (NBUBISI, 2002).

Em seu reconhecido trabalho divulgado em 1969, o ecologista Eugene Odum lança luz sobre a maneira pela qual os ecossistemas se transformam em resposta às ações humanas. Em seu modelo de estudo desenvolvido, aborda as relações funcionais entre os modelos de paisagens requeridas pelas pessoas e as funções ecológicas necessárias para suportá-las. Odum determinou diferentes categorias de paisagem de acordo com seus papéis ecológicos básicos: produção (agricultura, silvicultura), proteção (áreas úmidas, florestas antigas), múltiplo uso e usos não vitais (urbano, industrial). Por meio dessa divisão, o modelo forneceu uma base teórica para o melhor entendimento acerca do funcionamento e 
produtividade das paisagens, além de fornecer informações importantes sobre a dinâmica do fluxo de energia e ciclagem de nutrientes nos ecossistemas (NBUBISI, 2002).

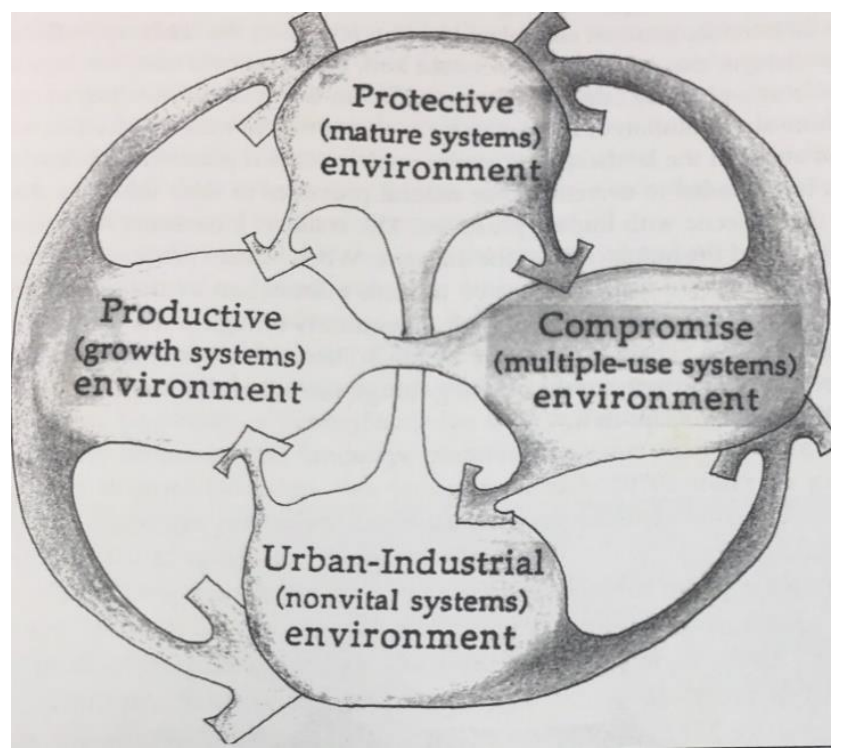

Figura 5- O modelo de compartimento do sistema de Eugene Odum relaciona os principais tipos de paisagem às funções ecológicas necessárias para suportá-los. Fonte: Fonte: NBUBISI (2002).

Além disso, os rápidos avanços na tecnologia de computadores entre as décadas de 70 e 80, a exemplo das técnicas de sensoriamento remoto como o Sistema de Informação Geográfica (SIG), tornaram possível o reconhecimento e a análise das paisagens com melhor precisão e em escalas maiores do que eram tradicionalmente examinados na área da ecologia. Assim, o sensoriamento remoto passou a ser utilizado como gerenciamento de grandes paisagens possibilitando também a oferta de informações científicas sobre os efeitos das ações humanas nos espaços a curto e longo prazo (HERZOG, 2013).

Nessa direção, arquitetos da paisagem começaram a aumentar esforços junto à cientistas na procura de informações pertinentes relativas aos impactos humanos na paisagem. Baseados em ferramentas da tecnologia da computação e nos sistemas de informação gráfica (SIG), os planejamentos baseados no víeis ecológico expandiram suas áreas de influência e a complexidade de suas questões (NBUBISI, 2002). Esse desenvolvimento tecnológico impulsionou o 
surgimento de uma disciplina intitulada "Ecologia de paisagem", um campo de estudo que possibilitou o aprofundamento da análise dos princípios ecológicos dentro da perspectiva da paisagem urbana (ALBERTI, 2008; FORMAN, 2010).

\subsubsection{A ECOLOGIA DA PAISAGEM}

O termo "ecologia da paisagem" foi apresentado pela primeira vez na década de 1930 por meio dos estudos do biogeógrafo alemão Carl Troll e a partir de suas inspirações nas perspectivas oferecidas pelas fotografias aéreas. No entanto, esta temática só foi reconhecida no nível global enquanto campo científico em meados da década de 1980, quando a tecnologia de sensoriamento remoto se tornou amplamente acessível aos profissionais interessados pela área, como ecologistas e geógrafos (WU, 2011).

O conceito ecologia da paisagem tinha como enfoque padrões especiais específicos em uma seção da paisagem, onde comunidades interagiam com o ambiente físico. Sendo o termo "ecologia" definido como o estudo das interações entre os organismos e o seu ambiente e o termo "paisagem" um mosaico com quilômetros de largura sobre os quais interagem ecossistemas locais com as atividades da terra, esses dois conceitos assumem relações relevantes e formam juntos um campo de estudo definido como "ecologia da paisagem" (DRAMSTAD; OLSON; FORMAN, 1996). Ao longo do tempo, o aperfeiçoamento da disciplina foi dominada por duas escolas de pensamento, sendo uma dominada pela perspectiva europeia e outra pela escola norte-americana.

O primeiro surgimento da ecologia da paisagem ocorreu na Europa por Carl Troll e por outros pesquisadores geógrafos da Europa Oriental e Alemanha. Essa vertente foi fortemente influenciada por disciplinas da geografia e arquitetura relacionadas com o planejamento regional (METZGER, 2001).

Caracterizada por uma visão mais holística, humanística e voltada para a sociedade, a temática da ecologia da paisagem foi apresentada baseada no planejamento da ocupação territorial, no estudo de paisagens 
fundamentalmente modificadas pelo o homem, denominadas "paisagens culturais", com enfoque voltado para as relações entre o homem, seu espaço de vida e soluções de problemáticas ambientais (WU; HOBBS, 2002; TRICART,1979). Nessa abordagem, Troll (1968) definiu o conceito como "o estudo das principais relações casuais complexas entre as comunidades da vida e o seu ambiente em determinada seção de uma paisagem".

A perspectiva norte-americana, por sua vez, trata a ecologia da paisagem por meio de um víeis mais analítico e biológico da ecologia, de início influenciada pela ecologia de ecossistemas, modelagem e análise espacial. Se difere da primeira por dar maior relevância às paisagens naturais, voltadas para conceitos como conservação da diversidade ecológica e manejo de recursos naturais (METZGER, 2001). Dentro dessa abordagem, os estudos de Richard Forman e Michel Godron ganharam bastante notoriedade. Forman e Gordon (1981) definem paisagem como uma área distinta e mensurável que engloba diversos conjuntos de ecossistemas em constante interação. A ecologia da paisagem, segundo os mesmos autores, é, portanto, o estudo dessas interações entre organismos e meio ambiente (ecologia) num determinado espaço mensurável (paisagem).

Ao se aplicarem à qualquer área terrestre, da região suburbana à agricultura e do deserto à floresta, os princípios da ecologia da paisagem podem ser analisados tanto nas áreas naturais preservadas quanto nas áreas de intensa atividade humana (DRAMSTAD;OLSON;FORMAN, 1996). Essas grandes áreas, tidas como mosaicos, podem ser categorizadas de acordo com modelos de espaciais definidos, intitulados como: matriz ecológica, manchas e corredores. A classificação desses fragmentos fornece uma estrutura conceitual dentro da qual os planejadores são capazes de explorar e identificar a evolução da estrutura da paisagem baseada nas suas interações com os processos ecológicos (FORMAM; GORDRON, 1986).

Esses fragmentos podem ser formados por áreas vegetadas, cursos d'água, florestas ou outras áreas onde a natureza faça parte, sendo estes naturais ou criados pelo o homem (FORMAN, 1995). Assim, os distintos arranjos e 
organizações entre esses elementos ou fragmentos originam os diversos tipos de modelos de paisagens ao longo do globo terrestre podendo assumir transformações pela ação antrópica ou processos naturais (DRAMSTAD, OLSON, FORMAN, 1996).

O modelo denominado matriz é o elemento que exerce maior influência sobre os processos de mudança da paisagem, funcionando como núcleo e desempenhando um papel essencial no funcionamento do sistema ecológico. Identificada como o berço de origem da fauna e flora, contém em geral um ecossistema equilibrado e a biodiversidade e heterogeneidade são suas características marcantes (FORMAN, GODRON, 1986).

As manchas são fragmentos da paisagem de tamanhos diversos e são habitadas por comunidades específicas e podem ser denominadas como "ilhas de biodiversidade" quando apresentam algum isolamento ou fragmentação (FORMAN; GODRON 1981). Pode ser formada a partir da fragmentação de áreas maiores de mata ou mesmo pela introdução de áreas naturais pelo homem para a formação de parques ou praças (DRAMSTAD; OLSON; FORMAN, 1996).

Os corredores são modelos formados por faixas lineares que conectam os núcleos aos outros fragmentos possibilitando o fluxo gênico entre as espécies da fauna e da flora. Podem ser compostos por cursos de água, corredores verdes ao longo de ferrovias ou estradas, trilhas para caminhada, entre outros (FORMAN, 1986). Dentre alguns dos serviços ecológicos oferecidos por esses modelos lineares estão: manutenção do equilíbrio ecológico, conexão entre paisagens fragmentadas, proteção à biodiversidade, controle de cheias, barreiras naturais e qualidade de água e vida animal. Além disso, os corredores podem compor áreas de recreação e lazer para a sociedade (FORMAN, 1995).

A atuação dos ecossistemas e os diversos usos adotados em cada unidade ou mosaico, fazem da paisagem um sistema vivo que apresenta três características: estrutura, funcionamento e mudança. A estrutura diz respeito ao padrão espacial e distribuição dos elementos da paisagem; a função são as interações entre os elementos espaciais, ou seja, distribuição de energia, fluxo de animais, plantas, água, vento, entre outros; já a mudança se refere à dinâmica ou 
alteração do padrão espacial da estrutura e funcionamento do mosaico ao longo do tempo (DRAMSTAD;OLSON;FORMAN, 1996).

\subsubsection{A PAISAGEM A SERVIÇO DA INFRAESTRUTURA: ALGUMAS REFERÊNCIAS}

Recentemente, a ideia de que as paisagens naturais contribuem para o bom funcionamento das cidades tem crescido muito no campo científico. A ideia do funcionamento da paisagem como infraestrutura, ou seja, a paisagem configurada por espaços produtores de serviços ambientais importantes, tem sido uma alternativa cada vez mais discutida com potencial para complementar ou até substituir os serviços ofertados pela infraestrutura convencional (BONZI, 2017).

De acordo com Bélanger (2009), a infraestrutura usual tem apresentado uma capacidade limitada para lidar com os desafios cada vez mais difíceis em decorrência da urbanização em massa. Ao longo do tempo, "os projetos de infraestrutura tem apresentado um caráter monofuncional de forma a segregar disposições básicas relativas à água, resíduos, transporte, alimentos e energia em departamentos separados e não relacionados" o que, em longos períodos, pode gerar resultados custosos e ineficientes.

Os parâmetros e soluções principais aplicadas no campo da urbanização desconsideram e, por vezes, até se opõem à base biofísica e os processos naturais tão importantes para o funcionamento da cidade e bem-estar da população. Em decorrência desse modelo monofuncional e não integrado à natureza, o meio urbano enfrenta problemas como ausência de áreas verdes com o aumento das áreas impermeáveis, alterações no sistema hídrico, inundações, desmoronamento de encostas, desertificação do solo, diminuição da umidade do ar e elevação da temperatura, além de outros (SPIRN,1984; RIBEIRO,2010; HOUGH, 1984; BONZI, 2017). Diante desse cenário, é preciso aplicar criatividade 
aos sistemas naturais para que possam atender os desafios da infraestrutura urbana (CORMIER; PELLEGRINO, 2008).

Apesar da concepção da paisagem enquanto infraestrutura esteja ainda em desenvolvimento, profissionais da arquitetura paisagística já desenvolviam tempos atrás projetos que consideravam a capacidade de suporte dos ecossistemas. Tais projetos estão associados às ideias e ações de conservação da natureza por meio de parques, refúgios da vida selvagem, florestas, rios além de planejamento da paisagem e desenvolvimento ambientalmente sensível (FRANCO, 2000).

Na sequência, são descritos alguns projetos que se destacaram de uma maneira bastante positiva no âmbito do planejamento ambiental, notoriedade obtida sobretudo pelos arquitetos paisagistas que conseguiram alicerçar fatores primordiais como a essência natural e atributos ecossistêmicos destes espaços. Ainda hoje estes projetos são beneficiados pelos inúmeros efeitos positivos ofertados pela própria natureza, força responsável por propor a qualidade e multifuncionalidade destes lugares onde atua.

Em virtude da grande variedade de projetos deste cunho, ressalta-se aqui como foi feita a seleção dos referenciais teóricos a seguir expostos, escolha esta que procurou englobar, principalmente, planos que priorizaram a integração entre as áreas verdes ou também com seus corpos d'água. Essa escolha se justifica como forma de evidenciar neste trabalho os benefícios, no campo da paisagem e no campo social, as associações deste cunho que são capazes de ofertar para a paisagem.

Partindo de uma escala mais abrangente, apresenta-se primeiramente o intitulado Emerald Necklace ou "Colar de Esmeraldas" em Boston nos Estados Unidos que, apesar de ter sido construído a partir do ano de 1880, constitui ainda hoje um símbolo internacional importante pela implementação da ligação entre um sistema de parques. Em seguida, ressalta-se o projeto de requalificação do Rio Cheonggyecheon em Seul, na Coreia do Sul, igualmente considerado como uma referência internacional, capaz de quebrar grandes paradigmas pela remoção de um elevado resgatando a vida do rio e suas margens. 
Quanto aos referenciais de projetos brasileiros, elegeu-se para apresentar neste trabalho primeiramente o caso de recuperação da Floresta da Tijuca no Rio de Janeiro, a qual teve o seu maciço original devastado, mas que foi depois recomposta e transformada em um parque urbano que oferta atualmente serviços ambientais e culturais. Por último, apresenta-se o chamado parque linear mais antigo do Brasil o chamado "Parque Natural Municipal do Iguaçu", que abrange áreas verdes que atuam na melhoria das enchentes e inundações do rio Iguaçu.

\section{Frederick Law Olmsted o Sistema de Parques em Boston, Estados Unidos}

Frederick Law Olmsted foi o primeiro a lançar as bases para o planejamento da paisagem e dentre suas obras mais importantes está o sistema de parques de Boston. Chamado de Emerald Necklace ou "Colar de Esmeraldas", este espaço público possui $10 \mathrm{~km}$ de extensão é formado por uma sequência de cinco parques ligados por ruas arborizadas de acordo com um traçado contínuo que envolve boa parte dos setores norte a oeste da cidade (PANZINI, 2013).

A intenção de Olmsted ao realizar o projeto em parceria com o arquiteto Charles Eliot era reverter alguns dos problemas de cunho ambiental enfrentados por Boston, uma das cidades industriais mais importante dos Estados Unidos até o início do século XX. A problemática, que incluía poluição dos rios, enchentes recorrentes e ausência de espaços públicos de lazer, impulsionou o desenvolvimento do Colar de Esmeraldas construído entre as décadas de 1880 e 1890 (PANZINI, 2013; HERZOG, 20013).

O plano se caracteriza como uma iniciativa pioneira e inovadora visto que conseguiu integrar na época soluções diversas da paisagem como saneamento, controle de enchentes, corredores viários e de recreação, áreas verdes e conservação ambiental. As ditas pedras preciosas do Colar de Esmeraldas, constituídas pelos parques Black Bay Fens, Leverett Park, Jamaica Park, Arnold Arboretum e Franklin Park (figura 6), foram também interligadas por meio da recuperação e renaturalização das margens do rio Muddy, dando origem à um corredor verde ecológico multifuncional (PANZINI, 2013; BONZI, 2017). 


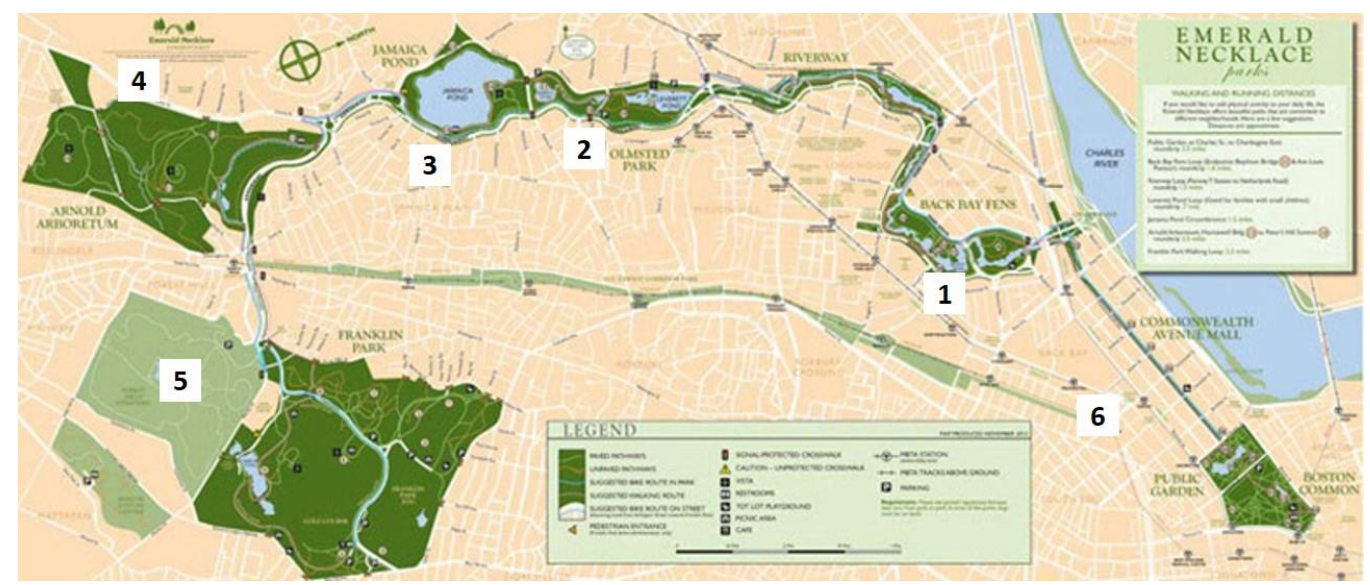

Figura 6- Mapa que ilustra a configuração do Emerald Necklace, o sistema de parques de Boston. 1) Back Bay Fens; 2) Leverett Park; 3) Jamaica Park; 4)Arnold Arboretum; 5) Franflin Park; 6) Commonwealth Avenue. Fonte: Site Emerald Necklace Conservacy. Disponível em: <https://www.emeraldnecklace.org/park-overview/emerald-necklacemap/>. Acesso em 21 jan. 2019.

O parque Black Bay Fens foi inicialmente o resultado de uma tentativa de sanear um ambiente de pântanos salobros e insalubres que inundava e ameaçava a saúde pública dos que moravam próximo à região. A partir de ideias que partiam tanto da arquitetura paisagística quanto da engenharia sanitária, Olmsted planejou a parte mais baixa desta zona como um alagado construído, formada por uma grande bacia com capacidade de retenção e purificação das águas poluídas por esgotos e efluentes industriais de maneira natural. Além disso, a proteção das áreas circunvizinhas sujeitas a enchentes era garantida por meio da implantação de declives suaves e margens irregulares capazes de reduzir a força das águas (SPIRN, 1995; PANZINI, 2013).

A partir do Back Bay Fens foi implantado a chamada Riverway, uma viaparque configurada por margens arborizadas ao longo do rio Muddy com efeito no controle de cheias. Para tanto, as margens do rio sofreram redimensionamento e terraceamento para acomodar o seu fluxo regular bem como o escoamento superficial das áreas adjacentes e enchentes. $O$ percurso do rio foi implementado ainda por alamedas e pontes e suas margens receberam a plantação de gramíneas, arbustos e árvores. 


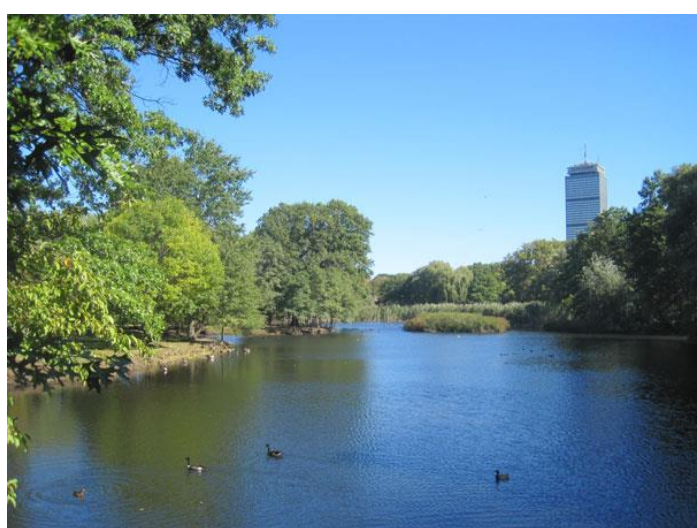

Figura 7- Hoje o lago do parque Back Bay Fens atua no controle de enchentes além de ser um destino agradável para recreação. Fonte: Site The Cultural Landscape Foundation. Disponível em:<https://tclf.org/landscapes/back-bayfens>. Acesso em 21 jan. 2019.

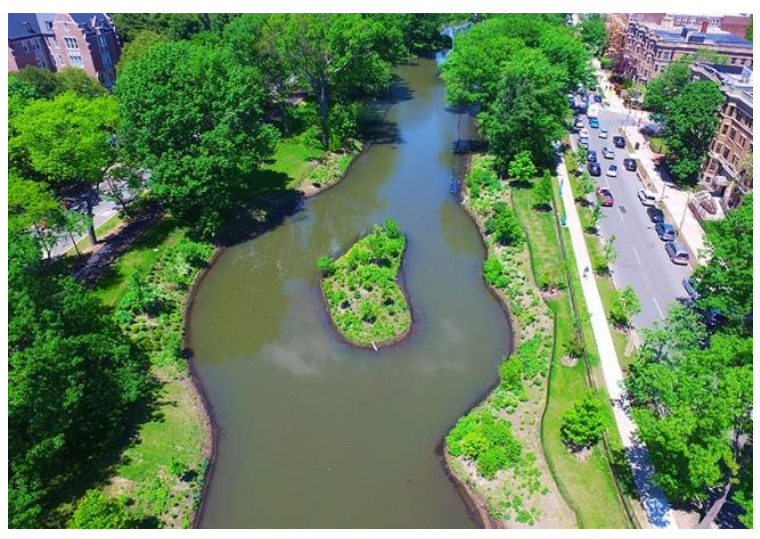

Figura 8- A Riverway: via caminho arborizado ao longo das margens do rio Muddy com efeito na regulação do controle de cheias.Fonte: Site Charter Contracting Company. Disponível em: < https://charter.us/our-work/muddy-river-floodrisk-restoration-project/>. Acesso em 21 jan. 2019.

Na sequência, o caminho da Riverway teve como destino dois lagos presentes nos parques Lverett Park e Jamaica Park. Este último parque abriga a nascente do rio Muddy e foi alvo do projeto em prol da conservação do seu lago, que na época das obras apresentou indícios de poluição devido a sua proximidade com fábricas de gelo presentes região. Hoje este lago oferece serviços ambientais e transformou a paisagem para que fosse sustentável a longo prazo (PANZINI, 2013; HERZOG, 2013).

O sistema de parques teve sua continuação com a Arboway um caminho tradicional de grandes dimensões totalmente tomado pelo verde e que incorporou o parque Arnold Arboretum, definido como um sítio de colina que abrigada a coleção científica de árvores da Universidade de Harvard e o vasto Franklin Park. Este último apresentava duas configurações distintas, contemplando uma área artificial voltada para o perímetro urbano e outra mais natural, identificada por suas grandes dimensões e caráter rural. Por fim, o sistema de parques ainda englobou uma outra via-parque chamada Commonwealth Avenue que interligava a área de Back Bay Fens ao jardim público de Boston localizado no centro, fato que possibilitou a ligação do coração da cidade a todo o sistema de parques criado (PANZINI, 2013). 


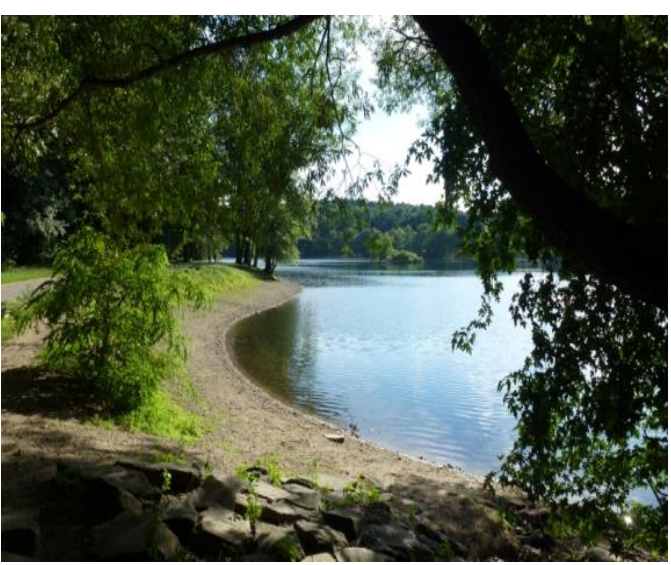

Figura 9- Espelho dágua presente no Jamaica Park. Fonte: Otterx for nature ana wildlife. Disponível em: <https://otterx.wordpress.com/2012/08/22 /olmstedparkboston/>._Acesso em 21 jan. 2019.

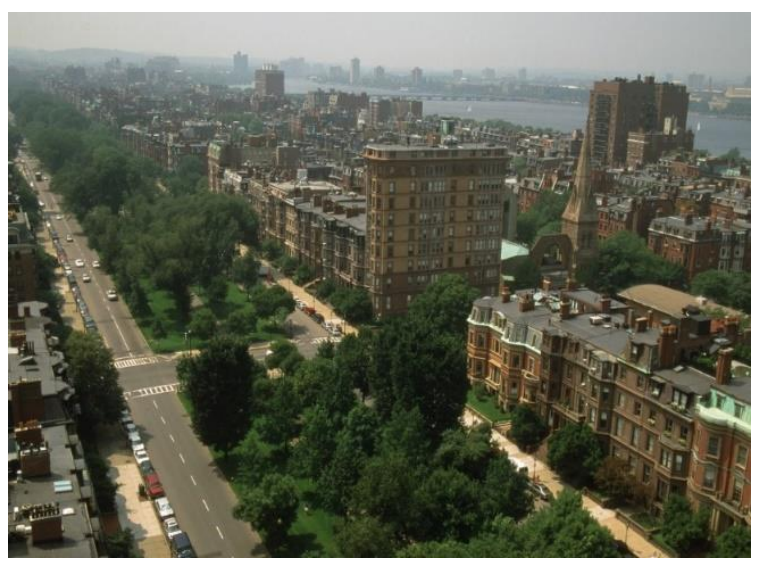

Figura 10- Visão da via- parque Commonwealth Avenue. Fonte: Grant Spencer. Disponível em:< https://www.digitalcommonwealth.org/search/c ommonwealth:4q77fs37x>. Acesso em 21 jan. 2019.

Os benefícios desse projeto ainda impactam de maneira positiva a qualidade de vida das pessoas, fruto da criação dos espaços públicos multifuncionais que oferecem serviços ambientais e culturais importantes como regulação de enchentes, limpeza do ar, recreação, lazer, entre outros. Como bem ressaltou Anne Spirn (1995), o plano paisagístico deste sistema de parques conseguiu solucionar problemas decorrentes da urbanização por meio da adaptação aos atributos ambientais ao invés de subjugá-los.

\section{O projeto de requalificação do Rio Cheonggyecheon em Seul, Coreia do Sul}

O rio Cheonggyecheon data do século 14 quando ainda era relativamente pequeno e percorria de maneira irregular no sentido leste a oeste da capital até desaguar no rio Han. Naquela época, o seu leito era bastante variável de acordo com o regime de chuvas e, diante de suas condições naturais e inundáveis, os governantes autorizaram o seu processo de retificação alegando como prioridades a segurança e bem-estar públicos. Diante da ocupação colonial japonesa entre os anos de 1910 e 1945 as implementações visando a saúde e segurança públicas prosseguiram com planos voltados para cobrir partes do então córrego por meio da construção de edifícios e leitos carroçáveis (ROWE,2013). 
Foi então que com a formação da república pelos coreanos em 1948 o rio Cheonggyecheon foi coberto por uma via pública que variava de 50 a 90 metros e que também recebeu um mercado ao ar livre além de empresas e comércios ao seu redor. Em seguida, entre os anos de 1967 e 1976 foi construída a via expressa elevada Cheonggyecheon que simbolicamente junto a outras vias representavam a modernidade e a era do automóvel no período do regime de ditadura pelo general Park Chung- Hee em 1961 (ROWE,2013).

Diante de alguns problemas como congestionamentos (no período de máxima utilização as vias chegavam a receber 120 mil veículos diariamente) e danos nas estruturas principais, ficou declarado a insustentabilidade do elevado entre os anos de 2000 e 2001. A partir disso, a intenção de remover a grande estrutura foi se intensificando junto com a possibilidade de resgatar o rio que fora sufocado. As ideias de revitalizar a área tomaram impulso com o projeto concebido pelo governo metropolitano de Seul sob a direção do vice-prefeito Yun- Jae Yang, arquiteto e paisagista que visavam na nova via de recreação uma grande oportunidade de melhorias relativas ao meio ambiente além de um artifício em prol da revitalização econômica (ROWE,2013).

As obras, que duraram 27 meses com início no ano de 2002 e término em 2005, efetuaram a demolição tanto das vias quanto os leitos carroçáveis que cobriam o rio, abrindo-se assim 20\% a mais do espaço original do córrego considerando o período de suas cheias ao longo de um período de 200 anos. Com o intuito de proporcionar a proximidade da população com o rio foram construídas ao todo 22 pontes além de elementos paisagísticos como arborização e caminhos para pedestres. 


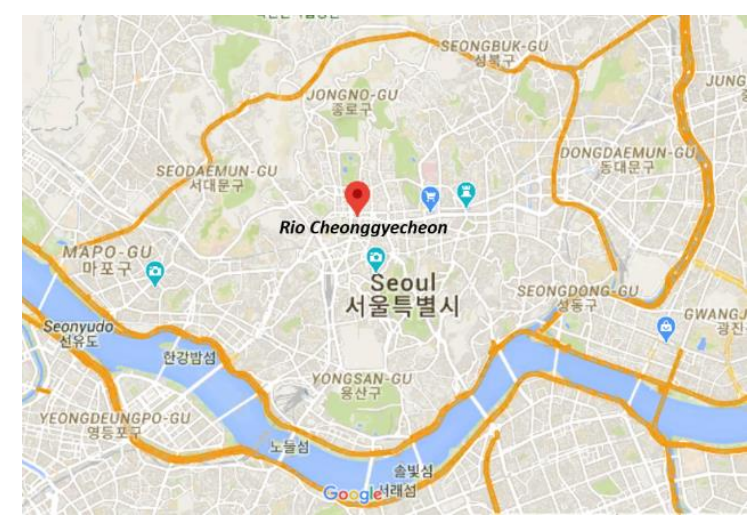

Figura 11- Localização do Rio Cheonggyecheon em Seoul. Fonte: Google Maps (2020).

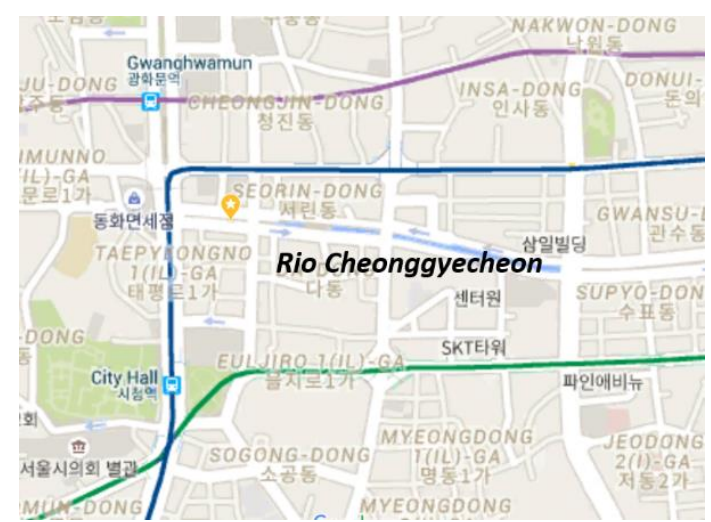

Figura 12- Localização do Rio Cheonggyecheon em Seoul. Fonte: Google Maps (2020).

O plano de restauração do rio Cheonggyecheon também passou a ser parte integrante de um plano maior do centro da cidade com a instalação de quatro grandes cruzamentos do córrego, cada um enfatizando uma função diferente nomeados como eixo cívico, eixo da mídia, eixo criativo e eixo verde. A questão relacionada ao tráfego foi resolvida pela oferta de mais transporte público além de faixas reversíveis nas ruas já existentes e outras opções de vias (ROWE,2013). 


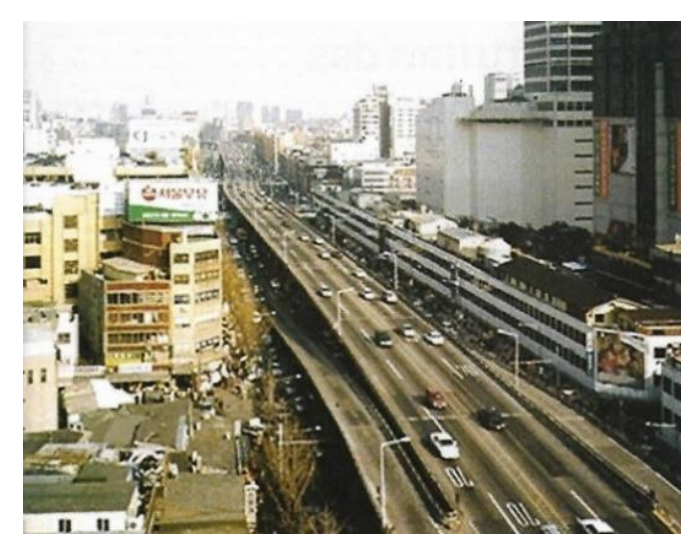

Figura 13- A Via Expressa Elevada Cheonggyecheon construída entre 1967 e 1976. Fonte: Jean Chunc.

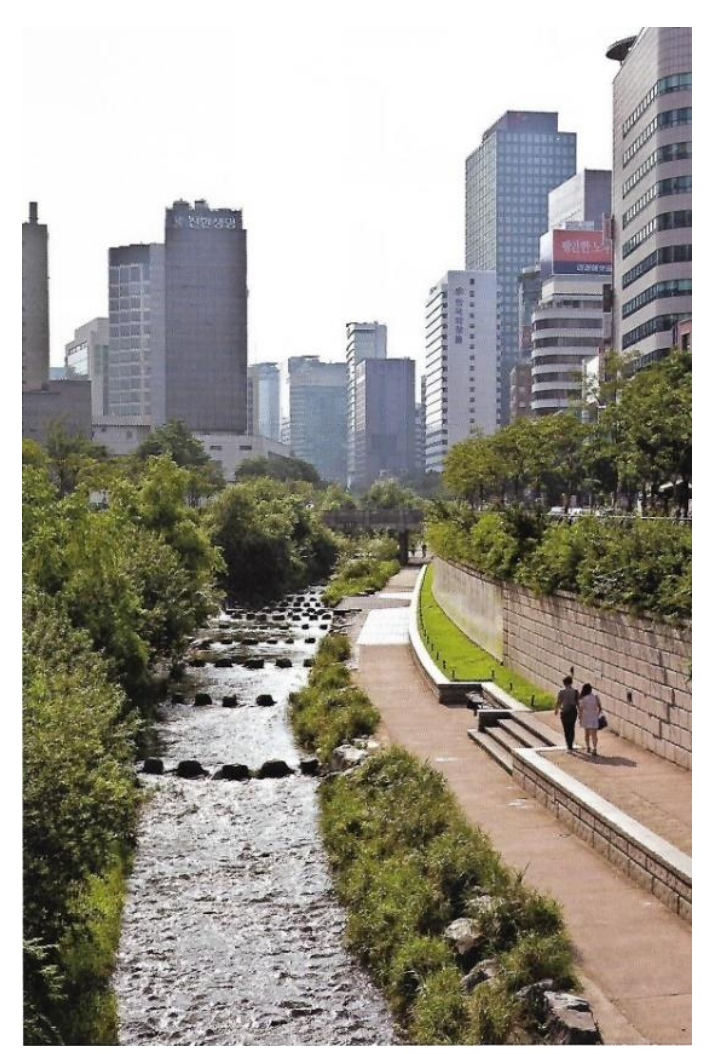

Figura 15- Caminho para pedestres às margens renaturalizadas do rio. Fonte: Jean Chunc.

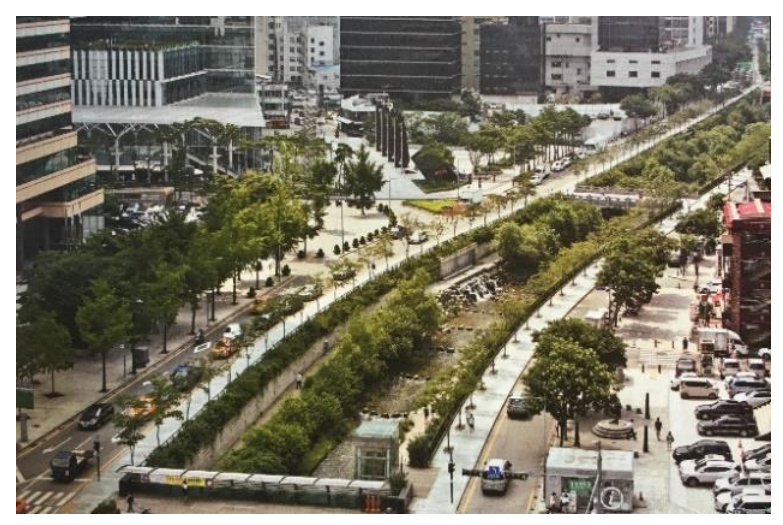

Figura 14- $O$ rio Cheonggyecheon revitalizado após a demolição da Expressa Elevada. Fonte: Jean Chunc.

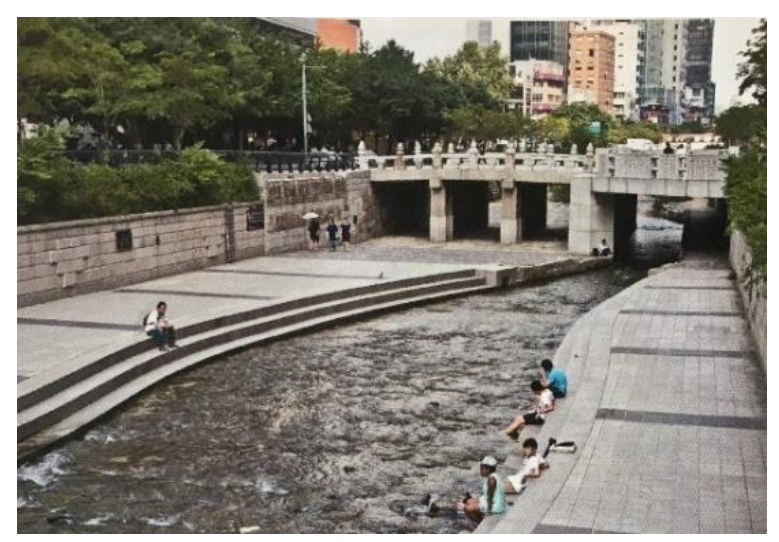

Figura 16- A proximidade das pessoas com o rio. Fonte: Jean Chunc.

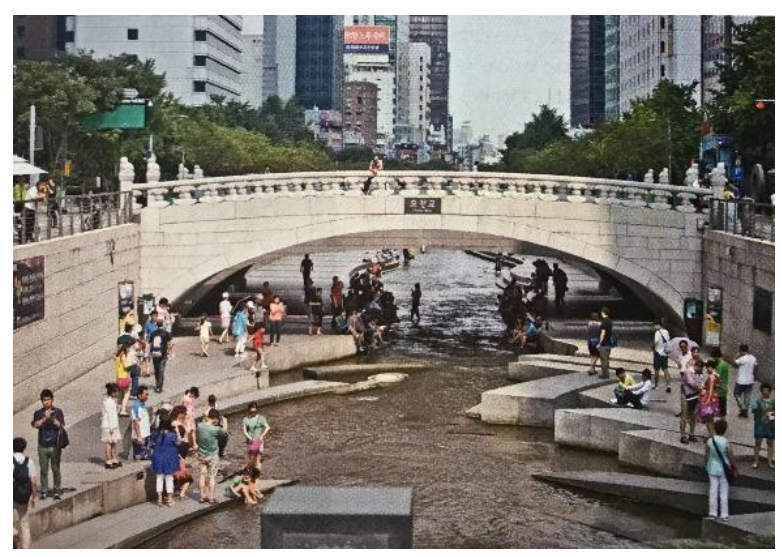

Figura 17- Margens do rio como espaço de recreação e lazer. Fonte: Jean Chunc. 
De acordo com pesquisas científicas, o projeto de requalificação alcançou impactos positivos em rede. O ressurgimento rio Cheonggyecheon contribuiu para a qualidade ambiental da cidade com a diminuição do efeito da ilha de calor abaixando o nível de poluição e a temperatura em até cinco graus durante o verão. Outro tipo contribuição nesse campo diz respeito ao aumento em 639\% da biodiversidade no local como espécies de plantas, peixes, pássaro, invertebrados aquáticos, insetos e mamíferos. Além disso, o plano causou também restauros no campo social e econômico por meio do incentivo à utilização de espaço público, oferta de atividades que renovaram a vida noturna além de tecer novas conexões entre áreas da cidade antes separadas pela via expressa (ROWE,2013).

O projeto de requalificação do rio Cheonggyecheon exemplifica de maneira clara como o a valorização de elemento ambiental paisagístico pode reverberar tantos efeitos positivos no meio em que se vive. O resgate de um corpo hídrico que antes era soterrado em prol do fluxo de veículos hoje atua como uma verdadeira rede verde-azul estrutural ofertando serviços ambientais, culturais e econômicos de extrema importância para a cidade.

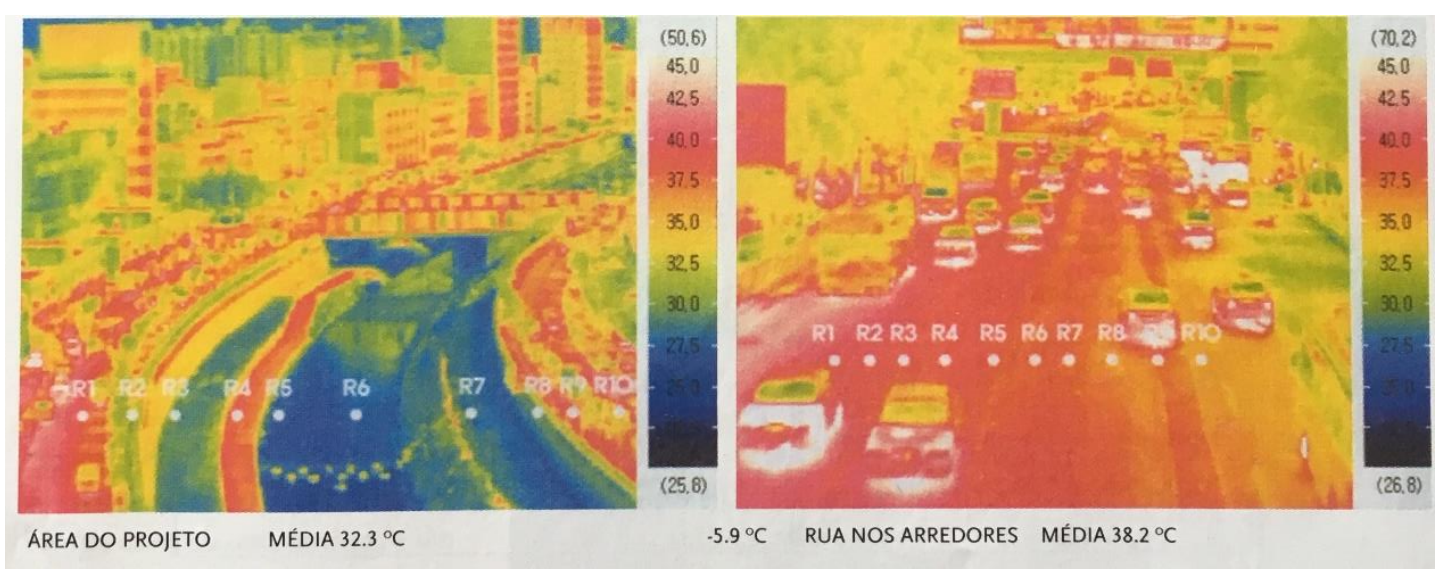

Figura 18- Painel que mostra a diferença de temperatura da região indicada por cores, depois e antes do projeto respectivamente. Fonte: Jean Chunc 


\section{A recuperação da Floresta da Tijuca no Rio de Janeiro (RJ), Brasil}

A Floresta da Tijuca, uma das mais famosas paisagens brasileiras, teve seu maciço original devastado por conta dos ciclos econômicos coloniais dando passagem à cultura da cana-de-açúcar e depois à do café.

Como consequência do quase desaparecimento da floresta, a cidade do Rio de Janeiro (RJ) foi impactada com sérias crises de abastecimento de água. $O$ aqueduto abastecia a cidade no século XVIII por meio das águas oriundas do Maciço da Tijuca (berço de muitas nascentes). Com o crescimento da população, tal distribuição foi se tornando cada vez mais insuficiente (FRANCO, 2000).

Diante do problema que fora atribuído ao desmatamento da bacia, o governo convocou Major Archer como administrador da floresta o qual iniciou o no ano de 1862 reflorestamento da floresta com a ajuda de seis escravos e alguns feitores, encarregados e assalariados. Ao longo da sua gestão Archer plantou aproximadamente 62 mil mudas dando preferência às plantas nativas e com isso recuperou as cabeceiras de alguns rios da região (FRANCO, 2000).

Após renunciar ao cargo, Archer foi substituído por Escragnolle que assumiu a administração da floresta no período de 1874 a 1888 e viu a possibilidade de transformá-la em um parque urbano com áreas de recreação e lazer para a população. Para tanto, contou com a parceria do botânico francês Glaziou e, juntos, conseguiram transformar a floresta em um lugar atrativo com a implantação de escadas, belvederes e outros melhoramentos (FRANCO, 2000).

Atualmente a floresta faz parte da Reserva da Biosfera da Mata Atlântica, uma iniciativa das Nações Unidas e pertence ao Parque Nacional da Tijuca o qual se divide em quatro setores, sendo eles: Floresta da Tijuca, Serra da Carioca, Pedra da Gávea/ Pedra Bonita e Pretos Forros/ Covaca. 


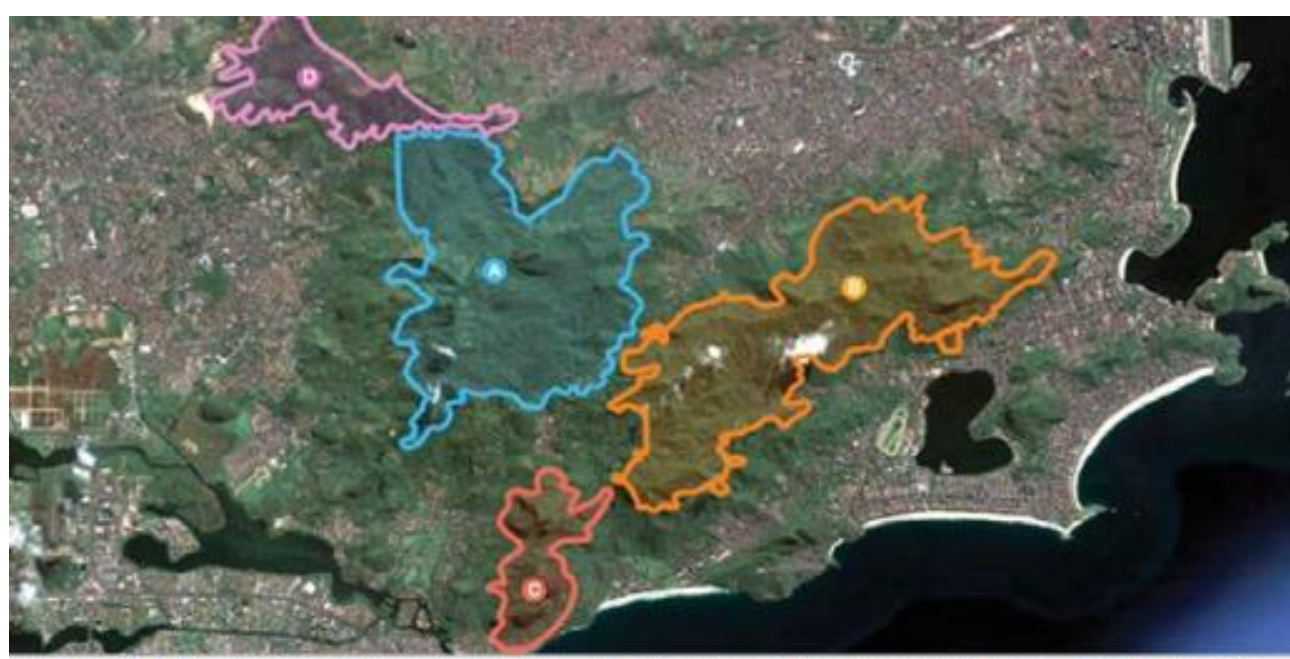

Mapa da distribuiça dos setores do Parque Nacional da Tijuca no Rio de Janeiro: Setor A - Floresta da Tijuca; Setor B - Serra da Carioca; Setor C-Pedra da Gávea / Pedra Bonita, Setor D - Pretos forros / Covanca.

Figura 19- Mapa da distribuição dos setores do Parque Nacional da Tijuca no Rio de Janeiro. Fonte: Guia de campo do Parque Nacional da Tijuca (2013).

Hoje, a Floresta da Tijuca atua em prol da qualidade de vida de moradores das regiões próximas com a oferta de áreas de recreação, lazer e temperatura de 3 a $10^{\circ} \mathrm{C}$ mais amena do que a do nível do mar. Dentre outros benefícios ofertados pela floresta devido às intervenções paisagísticas destacam-se: oferta de biodiversidade, qualidade das águas urbanas e controle de enchentes, regulação climática e controle de poluentes. Além dos serviços ambientais que a paisagem proporciona, o lugar também abrange o Cristo Redentor conformando um cenário que é identidade e símbolo de grande valor que alimenta o turismo na capital carioca (BONZI, 2017). 


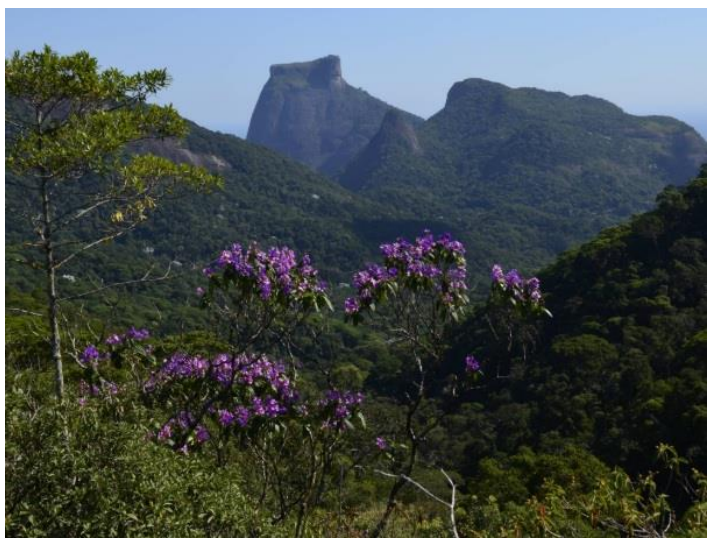

Figura 20- Pico presente no Parque Nacional da Tijuca. Fonte: Site Parque Nacional da Tijuca disponível em: <http://parquenacionaldatijuca.rio/galeria.ph p\#fotos?id=27> . Acesso em 23 jan. 2019.

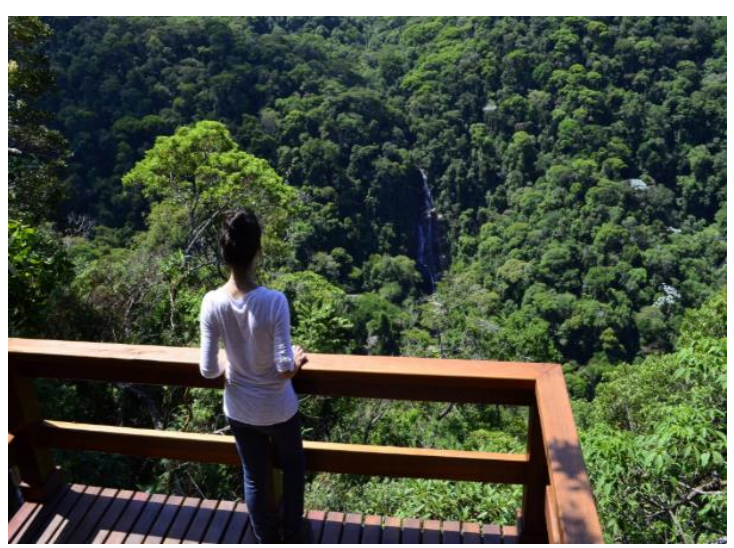

Figura 21 - Vista da Floresta da Tijuca a partir do alto do mirante. Fonte: Site Parque Nacional da Tijuca disponível em:<http://parquenacionaldatijuca.rio/galeria. php\#fotos?id=27>. Acesso em 23 jan. 2019.

\section{O Parque Natural Municipal do Iguaçu}

O Parque Natural Municipal do Iguaçu fica situado nas fronteiras dos municípios de Curitiba, Pinhais e São José dos Pinhais. A princípio, os motivos que guiaram a sua elaboração eram baseados em questões sanitárias e ambientais da região. Localizado nas planícies do Rio Iguaçu, a região compõe o ponto final do sistema de drenagem urbana de Curitiba.

A sua construção também partiu do propósito de evitar a conturbação entre as cidades de Curitiba e São José dos Pinhais além de impedir o crescimento de loteamentos desordenados à margem do Rio Iguaçu. A planície deste rio se caracterizava no passado por uma área de pequeno valor comercial devido uma série de fatores como riscos de inundação, falta de infraestrutura e grande distância do centro de Curitiba.

Nesse contexto, o projeto do parque foi realizado pelo Instituto de Pesquisa e Planejamento de Curitiba (IPPUC) possuindo 14 km de extensão e mais de 8 milhões de metros quadrados. É considerado o parque linear mais antigo do Brasil e um dos maiores parques urbanos do país (ANDRADE, 2009). 


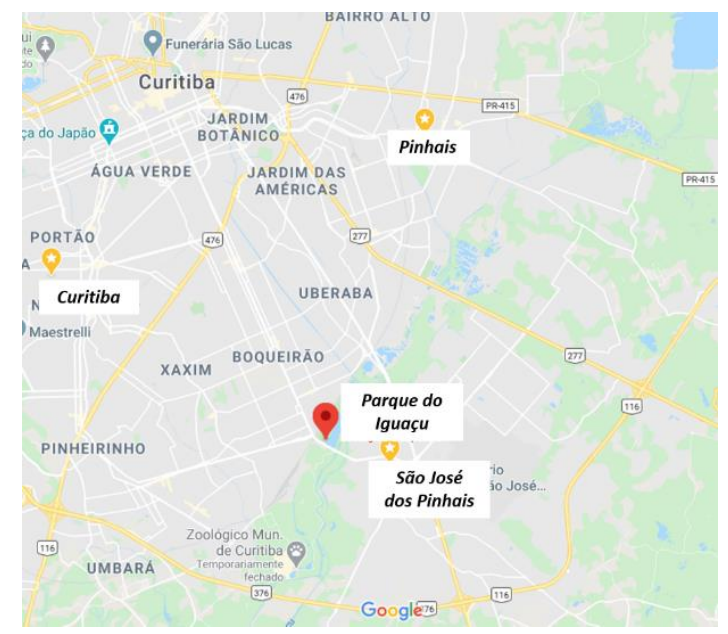

Figura 22- Localização do Parque Natural Municipal do Iguaçu. Fonte: Google Maps (2020).

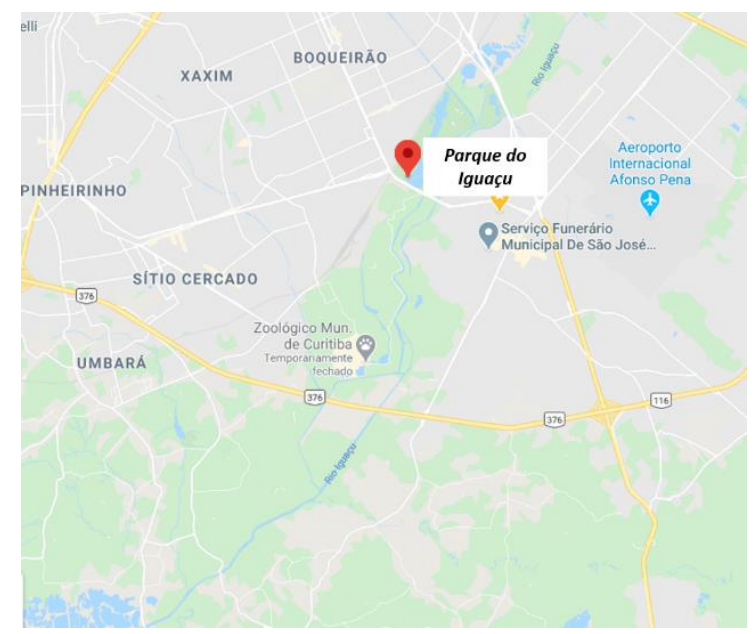

Figura 23- Localização do Parque Natural Municipal do Iguaçu. Fonte: Google Maps (2020).

A instituição do parque também partiu da premissa de ofertar uma área de lazer com caráter metropolitano abrangendo não apenas a capital Curitiba como também os outros municípios vizinhos. Além disso, o Parque Iguaçu visava também potencializar os índices de área verde por pessoa em Curitiba, visto que o Plano Ditetor de 1964 constatou que a cidade tinha um grande défcit neste aspecto.

As áreas verdes do parque hoje atuam na melhoria da drenagem do Rio Iguaçu tendo em vista que medidas de canalização e retificação foram implementadas nos seus tributários com a sobrecarga do seu leito e trazendo como consequência enchentes e inundações. A extensa área do parque foi planejada também para servir como uma reserva natural e para atuar também na preservação da fauna e da flora. Hoje, sua extensão funciona como um grande corredor de biodiversidade ao possibilitar o deslocamento de espécies animais e vegetais e abrigar inúmeras espécies contribuem para preservação e conservação da paisagem (ANDRADE, 2009). 


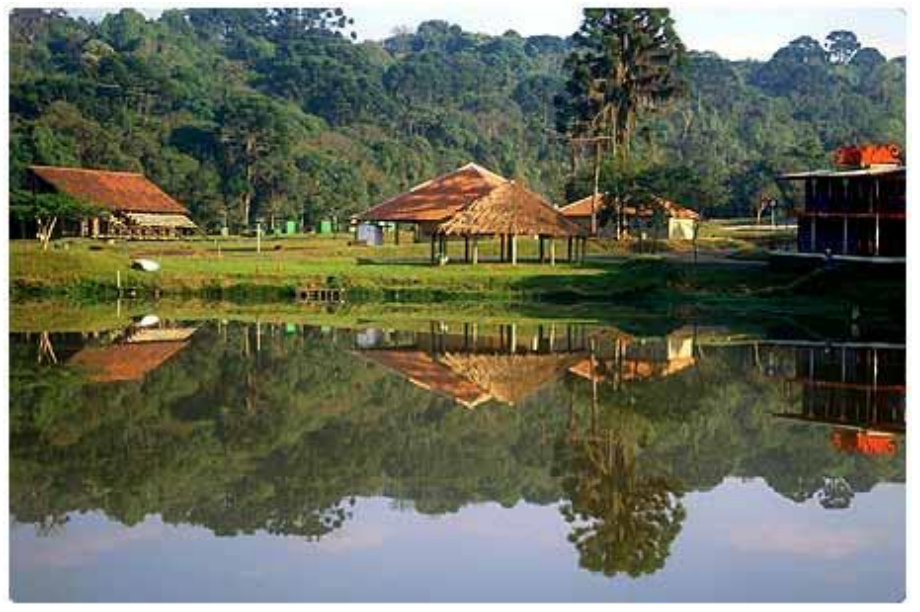

Figura 24- Parque Natural Municipal do Iguaçu. Fonte: Disponivel

$<$ https://www.guiadasemana.com.br/curitiba/turismo/esta belecimento/parque-municipal-iguacu>. Acesso em 20 de jan. 2019

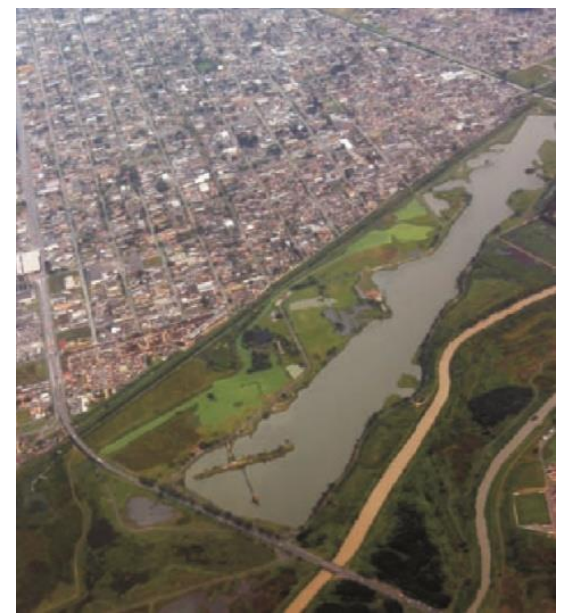

Figura 25- Raia Náutica com vista para a cidade de Curitiba. Fonte: Bonacin, André (s/d)

Tendo em vista os amplos benefícios que todos esses planos da paisagem anteriormente citados oferecem, fica claro a importância de se considerar os princípios e características naturais de cada localidade, uma vez que essas condições nativas são capazes de atuarem como uma força regeneradora e, assim, solucionarem inúmeras complicações recorrentes nas cidades. Poluição, enchentes ou tamponamento de rios, ausência de espaços públicos e de lazer, poluição do ar, ilhas de calor, baixa biodiversidade são alguns dos problemas abordados nestes referenciais projetuais citados, os quais, apoiados em ações baseadas na natureza, formaram uma rede verde estrutural associada a corpos hídricos que hoje atua no resgate de valores primordiais para a qualidade de vida na cidade. 


\section{CAPÍTULO 2}

\section{A INFRAESTRUTURA VERDE}

A expressão "infraestrutura verde" tem se tornado cada vez mais recente nas discussões que envolvem a natureza e a cidade. Reconhecida como uma ferramenta de planejamento que promove inúmeros benefícios à paisagem, tem caráter dinâmico com a capacidade de se adaptar às cidades e às áreas ocupadas pela população. Ela considera que os sistemas naturais, por meio dos seus serviços, conseguem desempenhar funções tão importantes quanto as infraestruturas tradicionais e que são indispensáveis para o bom funcionamento do espaço urbano. Nessa direção, tem como objetivo agregar os elementos naturais tornando-os parte integrante da paisagem em diversas escalas, agindo como uma rede de suporte para a vida das pessoas.

\subsection{ORIGEM E CONCEITOS DA INFRAESTRUTURA VERDE}

Apesar do termo "infraestrutura verde" ser recente, sua base conceitual não é algo novo. Mencionada com cada vez mais frequência nos campos relacionados à paisagem em todo o mundo, a expressão tem suas raízes nas ideias de conservação da natureza e se origina a partir de dois importantes conceitos. 0 primeiro diz respeito à conexão de parques e outras áreas verdes com oferta de benefícios para a população e o segundo faz referência à preservação e ligação das áreas naturais proporcionando biodiversidade e impedindo a fragmentação dos habitats (BENEDICT; MCMAHON, 2006).

Essa ideia considerar a paisagem como um mosaico integrado já era pensada em meados do século XIX e início do século XX por profissionais da área, como já dito anteriormente. Nos seus trabalhos relacionados aos parques públicos, o arquiteto Frederick Law Olmsted (1903) foi um dos pioneiros nesta 
temática ao defender que os parques precisavam estar conectados entre si e aos bairros residenciais vizinhos: "Um sistema conectado de parques e vias é expressamente mais completo e útil do que uma série de parques isolados" ${ }^{\prime 4}$.

A expressão infraestrutura verde teve sua origem de fato na Flórida no ano de 1994 por meio de um relatório dirigido ao governo americano intitulado "Relatório da Comissão de Greenway". Tinha como propósito tratar das ideias relacionadas à conservação do meio ambiente e defender a importância dos sistemas naturais, tidos como elementos tão ou mais importantes que os componentes da infraestrutura tradicional ou cinza (responsável por oferecer energia, transporte, abastecimento da água ou coleta de esgotos). Intensifica-se a partir de então a ideia de que os espaços naturais são de fundamental importância para que o planejamento da paisagem ocorra de modo sustentável agregando valor ao desenvolvimento das cidades (FIREHOCK, 2010).

A abordagem da infraestrutura verde se diferencia das demais temáticas convencionais ligadas à sustentação da paisagem por enfatizar a integração entre ações de conservação e desenvolvimento, conforme explica os autores Benedict e McMahon (2006, p.2):

A infraestrutura oferece a organização espacial que atende a
conservação e o desenvolvimento, reconhecendo a necessidade
de oferecer lugares para a população viver, trabalhar, fazer
compras e desfrutar da natureza. A infraestrutura verde ajuda
comunidades a reconhecer e priorizar oportunidades de
conservação e a planejar o desenvolvimento de maneira a
otimizar o uso do solo para atender as necessidades das pessoas
e da natureza

Neste escopo, a definição do conceito da infraestrutura verde se mostra bastante abrangente e compreende fatores ambientais, sociais e econômicos. Os autores Benedict e McMahon (2006, p.1) deixam claro a interdisciplinaridade e multifuncionalidade desta modalidade:

É uma rede interconectada de áreas naturais e outras áreas livres que conserva os valores e funções do ecossistema natural, mantém o ar e a água limpos e proporciona inúmeros benefícios

\footnotetext{
${ }^{4}$ Charles E. Little. Greenways for America. The Johns Hopkins University Press, Baltimore and London, 1989.
} 
para o homem e a vida silvestre. Usado nesse contexto, infraestrutura verde é a estrutura ecológica para a saúde ambiental, social e econômica- em suma, nosso sistema de suporte de vida natural

A autora Maria de Assunção Ribeiro Franco ressalta o conceito da infraestrutura verde enquanto ferramenta do planejamento e desenho ambiental ressaltando sua importância no âmbito do desenvolvimento territorial sustentável (FRANCO, 2010,p.141):

No planejamento e desenho ambiental, a infraestrutura verde pode ser entendida como uma rede interconectada de áreas verdes naturais e outros espaços abertos que conservam valores e funções ecológicas, sustentam ar e água limpos e ampla variedade de benefícios para as pessoas e a vida selvagem que deverão nortear as ações de planejamento e desenvolvimento territoriais que devem garantir a existência dos processos vivos no presente e no futuro

Franco (2019) acrescenta que a infraestrutura verde não envolve compreensões comuns sobre espaços verdes e abertos, reconhecidos na maioria das vezes pelas pessoas como um local de lazer, parque ou área isolada. Nessa direção, a autora explica que a infraestrutura verde reconhece o verdadeiro valor dessas áreas vegetadas (FRANCO, 2019, p.12):

\begin{abstract}
A infraestrutura verde traz consigo a ideia do espaço aberto e verde como parte de um sistema interligado, que é protegido e gerenciado pelos benefícios ecológicos que presta e, portanto, proteger e restaurar o nosso sistema suporte de vida natural passa de "comodidade" para "necessidade"
\end{abstract}

Franco (2019, p.12) ressalta ainda que a infraestrutura verde pode ser compreendida enquanto conceito e processo. Como conceito, sua gestão e elaboração proporcionam a criação de espaços verdes voltados para preservação, usos recreativos e demais valores humanos. Já como processo, atua na identificação e análise do território apontando áreas a serem conservadas ou 
propícias ao desenvolvimento, auxiliando assim, o crescimento urbano em consonância com aspectos culturais, recursos naturais e biodiversidade.

A autora Cecília Herzog aborda a infraestrutura verde sob uma perspectiva holística que compreende não só os aspectos naturais existentes na paisagem como também a transformação das construções existentes, capaz de reduzir o impacto da urbanização em diferentes escalas de abrangência (HERZOG, 2013, p.111):

(...) compreende a cidade como um sistema socioecológico, por meio de uma visão holística, sistêmica. Consiste em planejar, projetar e manejar construções e infraestruturas novas e existentes, de modo a transformá-las em espaços multifuncionais- que fazem parte de uma rede interligada de fragmentos vegetados ou permeáveis, conectados por corredores verdes e azuis, nos quais a biodiversidade protege e melhora a qualidade das águas, objetivando reestruturar 0 mosaico da paisagem em múltiplas escalas

Ao oferecer benefícios às esferas ambiental, econômica e social, a infraestrutura verde pode ser uma resposta para o paradigma da incerteza enfrentado pelas cidades modernas. Esse artifício parte de uma visão sistêmica da paisagem que propõe a transformação de áreas impermeabilizadas e monofuncionais em espaços multifuncionais, garantindo o equilíbrio dinâmico, sustentável e resiliente do ecossistema urbano. Assim, a finalidade da infraestrutura verde é promover a biodiversidade urbana por meio da oferta de serviços ecossistêmicos essenciais e, assim, oferecer a melhoria da qualidade de vida para as pessoas da cidade (HERZOG, 2013).

\subsection{PRINCÍPIOS DA INFRAESTRUTURA VERDE}

Existem vários fundamentos que contribuem para a prática do conceito da infraestrutura verde. Os autores Benedict a McMahon (2006) apresentam em sua publicação "Green Infrastructure - Linking Landscapes and Communities" dez 
dos princípios fundamentais que "fornecem uma abordagem estratégica e uma estrutura para a conservação que possa promover o uso sustentável da terra enquanto beneficia as pessoas e a natureza" (BENNEDICT; MCMAHON, 2006, p.36).

\begin{tabular}{l}
\hline 1. A conectividade é a chave \\
2. O contexto importa \\
3. Deve ser embasada em conhecimentos científicos e na teoria prática do \\
planejamento do uso do solo \\
4. Pode e deve funcionar como uma organização espacial tanto para a \\
conservação quanto para o desenvolvimento \\
5. Deve ser planejada e protegida antes do desenvolvimento \\
6. É um investimento público fundamental que deve ter prioridade de \\
financiamento \\
7. Proporciona benefícios para a natureza e para as pessoas \\
8. Respeita as necessidades e os desejos dos proprietários e de outros autores \\
envolvidos \\
9. Deve conectar-se com atividades da comunidade e do entorno \\
10. Requer um comprometimento a logo prazo
\end{tabular}

Tabela 1- Os dez princípios da infraestrutura verde. Fonte: Adaptado de Benedict e McMahon (2006)

Dentre os princípios estabelecidos por Bennedict e McMahon (ver tabela 01), a conectividade está dentre os mais importantes e é intitulado como "princípio chave". Ele evidencia a conexão entre os diferentes componentes do sistema natural como parques, reservas, áreas ribeirinhas, zonas úmidas e outras áreas verdes de maneira a garantir serviços ecológicos vitais tais como: abastecimento de água; tratamento e armazenamento das águas pluviais; melhoria do microclima; prevenção de enchentes e deslizamentos; amenização das ilhas de calor; aumento e melhoria da biodiversidade nativa, entre outros (BENEDICT; MC MAHON, 2006; CORMIER; PELLEGRINO, 2008; HERZOG, 2013).

Ainda no que se refere ao princípio da conexão, percebe-se a influência da Teoria da Ecologia da Paisagem desenvolvida por Forman e Dramstad (1986). Esse campo de estudo defende a importância de se interligar as áreas naturais ao longo do ambiente urbano entre si e às matrizes ecológicas (DRAMSTAD, OLSON, FORMAN, 1996, p.5): 
São princípios simples e holísticos que amarram território, vida selvagem e pessoas. Como planejadores urbanos devemos costurar essa rede de mosaicos formados por manchas e corredores (...) para impedir que a paisagem se desmanche

Enquanto nesta disciplina a paisagem é interpretada por meio das unidades matriz, mancha e corredor, o campo da infraestrutura verde engloba os elementos intitulados hubs, links e sites responsáveis pela formação de uma rede integrada, conforme explica Franco (2019, p.14):

(...) pode-se considerar os princípios da infraestrutura verde como uma "antropização" dos princípios da ecologia da paisagem quando transforma o conjunto mancha-corredormatriz em sítios-ligações núcleos, tornando a ecologia e seus processos aplicáveis ao planejamento das cidades e suas redes, intraurbanas e interurbanas.

De acordo com Benedict e Mc Mahon (2006), "hubs" ou "núcleos" são unidades que ancoram as ligações da infraestrutura verde. Possibilitam espaço para fauna e flora e ofertam condições favoráveis para a vida selvagem, pessoas e processos ecológicos que se deslocam ao longo do sistema. Podem adquirir diversas formas e tamanhos e incluem reservas e áreas protegidas, grandes terras públicas, áreas privadas, parques comunitários ou outras áreas verdes que assumem a proteção e restauração de seus recursos.

Os "links" são conexões responsáveis pela ligação do sistema e permitem que a infraestrutura verde funcione como uma grande rede. Esses elementos também variam de tamanho e podem atuar como conexões dos ecossistemas da paisagem, proteção de lugares históricos ou como oportunidades para recreação. Podem ser espacializados em: áreas naturais que conectam parques existentes; cinturões verdes; corredores fluviais ou zonas de proteção que podem aliviar a tenção entre usos da terra urbana e rural, proporcionando benefícios ecológicos e sociais para a vida urbana e moradores.

Já os "sites" são unidades menores que os "hubs" e podem ou não estar conectados de maneira espacial ao conjunto. Apesar disto, essas unidades fazem 
parte da rede de infraestrutura verde na medida em que oferecem benefícios ecológicos e sociais como proteção ao habitat de animais selvagens ou oferta de áreas para recreação e lazer integradas à natureza.

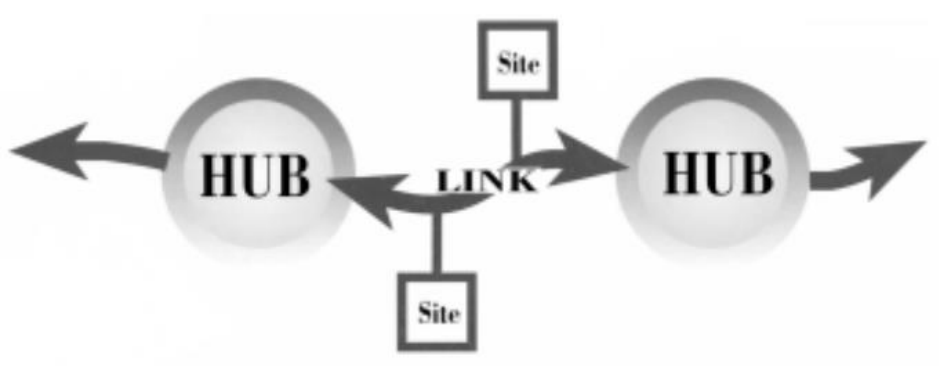

Figura 26- Esquema básico de uma rede de infraestrutura verde. Fonte: Benedict e MacMahon (2006)

Ao possibilitar a circulação de espécies e populações entre os diversos fragmentos compõem o mosaico da paisagem, a conectividade possibilita que funções naturais ocorram com influência para a sobrevivência humana e para a sustentabilidade (HERZOG, 2010). Ahern (2003) também evidencia o papel da conectividade nas áreas urbanas e define o conceito como (AHERN, 2003, p.40):

A característica espacial dos sistemas (i.e. paisagens), que possibilita e dá suporte à ocorrência de processos e funções específicos, através das adjacências, proximidade ou ligação e conexão funcional. A sustentabilidade de determinados processos na paisagem, depende da conectividade. Esses processos incluem, por exemplo, o movimento de espécies e populações de fauna e flora silvestre, o fluxo de águas, de nutrientes e o movimento do homem.

Franco (2019) ressalta que a infraestrutura verde não é formada inteiramente por conexões verdes, sendo os corpos d'água componentes naturais que agregam valores relevantes à rede. Herzog (2013) complementa ao explicar que os corredores verdes e azuis são interconexões necessárias para que a sustentabilidade aconteça, responsáveis pela manutenção ou reestabelecimento dos fluxos da biodiversidade animal, vegetal e das águas. Os corredores verdeazul podem se fazer presentes ao longo de rios e canais renaturalizados ou em 
ruas densamente arborizadas associadas à canteiros permeáveis com espécies de plantas.

Essa associação entre as áreas verdes e os corpos hídricos funciona como um meio de lidar com problemas como inundações e condições climáticas extremas nas cidades por meio de zonas úmidas ou de espaços naturais abertos ao longo dos rios. Dentre os tantos benefícios ofertados, estão: regulação do sistema pluvial com prevenção de inundações e deslizamentos durante eventos extremos de chuvas, filtragem de poluentes químicos e sedimentos oriundos do escoamento, melhoria do microclima, oferta de habitat para plantas e vida selvagem, conservação da natureza, purificação das águas e do ar, criação de zonas para exercício e atividades recreativas, entre outros (BENEDICT; MC MAHON, 2006).

A medida também lança uma associação de enfoques de retenção, infiltração e filtração do escoamento superficial na área de intervenção com a consequente flexibilização e descentralização da infraestrutura urbana de drenagem (PELLEGRINO, 2017). Nesse sentido, a infraestrutura verde consiste em uma ferramenta de planejamento que promove a qualidade de vida urbana por meio da valorização dos serviços ambientais das cidades. Trata-se de uma possibilidade capaz e viável de substituir soluções higienistas e convencionais, principais responsáveis por agravar os problemas urbanos (CORMIER; PELLEGRINO, 2008).

Além do princípio da conectividade, outro princípio que a infraestrutura verde abrange é a multifuncionalidade, referente às variadas funções e benefícios ofertados por estas áreas naturais no contexto urbano. A seguir, apresenta-se uma tabela resumo baseada nas definições de Benedict e McMahon (2006), que aponta os elementos que podem ser agregados a uma rede de infraestrutura verde e suas respectivas funcionalidades. 


\begin{tabular}{|c|c|}
\hline \multicolumn{2}{|c|}{ Elementos e Funções da Infraestrutura Verde } \\
\hline Elementos & Funções \\
\hline $\begin{array}{l}\text { Parques públicos ou privados; reservas } \\
\text { ou áreas de preservação. }\end{array}$ & $\begin{array}{l}\text { Recupera e protege a fauna e flora, aumenta a } \\
\text { biodiversidade, conserva e restitui as } \\
\text { características da paisagem natural }\end{array}$ \\
\hline $\begin{array}{l}\text { Refúgios/ corredores da vida silvestre e } \\
\text { cinturões verdes }\end{array}$ & $\begin{array}{l}\text { Proporciona habitat para a vida selvagem, } \\
\text { favorece a migração e reprodução animal e } \\
\text { mantém a saúde da população }\end{array}$ \\
\hline $\begin{array}{l}\text { Terras ribeirinhas, pântanos, mangues, } \\
\text { planícies de inundação e áreas de } \\
\text { recarga e de aquíferos, rios e lagos }\end{array}$ & $\begin{array}{l}\text { Protege e recupera a quantidade e qualidade da } \\
\text { água, atua no manejo das águas pluviais e } \\
\text { mitigação das inundações, proporciona habitat } \\
\text { para organismos aquáticos e favorece o ciclo } \\
\text { hidrológico }\end{array}$ \\
\hline $\begin{array}{l}\text { Parques, corredores verdes e corredores } \\
\text { ripários, trilhas, ciclovias e vias } \\
\text { arborizadas }\end{array}$ & $\begin{array}{l}\text { Provê espaço para atividades ao ar livre, } \\
\text { oportunidades de transporte alternativo, } \\
\text { conexão e proteção dos componentes da rede e } \\
\text { conecta as pessoas à natureza }\end{array}$ \\
\hline Sítios históricos e arqueológicos & $\begin{array}{l}\text { Preserva uma ligação com herança cultural e } \\
\text { natural }\end{array}$ \\
\hline $\begin{array}{l}\text { Cinturões verdes, monumentos naturais, } \\
\text { mirantes, espaços abertos públicos }\end{array}$ & $\begin{array}{l}\text { Melhora os padrões de crescimento e } \\
\text { desenvolvimento, cria paisagens com apelo } \\
\text { visual, aumenta o orgulho e a identidade } \\
\text { comunitária }\end{array}$ \\
\hline $\begin{array}{l}\text { Fazendas, ranchos, pomares, hortas e } \\
\text { florestas controladas. }\end{array}$ & $\begin{array}{l}\text { Protege as terras cultiváveis, mantém } \\
\text { características e tradições rurais e sustenta } \\
\text { setores econômicos }\end{array}$ \\
\hline
\end{tabular}

Tabela 2- Elementos e funções da Infraestrutura verde. Fonte: Benedict e Mcmahon (2006) com adaptações

\subsection{EXEMPLOS E APLICAÇÕES}

A aplicação da infraestrutura vede pode se manifestar em diferentes escalas podendo ser multiescalar ou até interescalar. A articulação entre as diferentes escalas tem o potencial de oferecer serviços ambientais para a sustentabilidade de uma grande região ou cidade. De acordo com YU (2006), a infraestrutura verde pode se manifestar na macro escala, na escala intermediária e na pequena escala.

Na macro escala, a infraestrutura verde pode ser expressa como uma paisagem regional que atua na regulação de enchentes bem como na formação de corredores ecológicos, recreativos e de valor histórico os quais protegem e definem o padrão de crescimento urbano da cidade. 


\section{Cidade de Estocolmo, Suécia}

Como exemplo de paisagem regional tem-se a cidade de Estocolmo, situada na Suécia. Eleita em 2010 como a Cidade Verde da Europa ${ }^{5}$, a cidade está situada em um arquipélago e possui lagos cercados por corredores verdes que conservam as águas e conformam parques multifunc ionais muito frequentados ao longo das quatro estações do ano. A cidade possui inúmeros parques e praças que contribuem para a qualidade de vida dos moradores e é abastecida principalmente pelas águas do lado Mälaren cercado por uma densa ocupação urbana. Como forma de propiciar a qualidade de suas águas, o lago é envolvido por corredores verdes multifuncionais com grandes árvores que proporcionam caminhos agradáveis para as pessoas e se contato direto com a natureza.

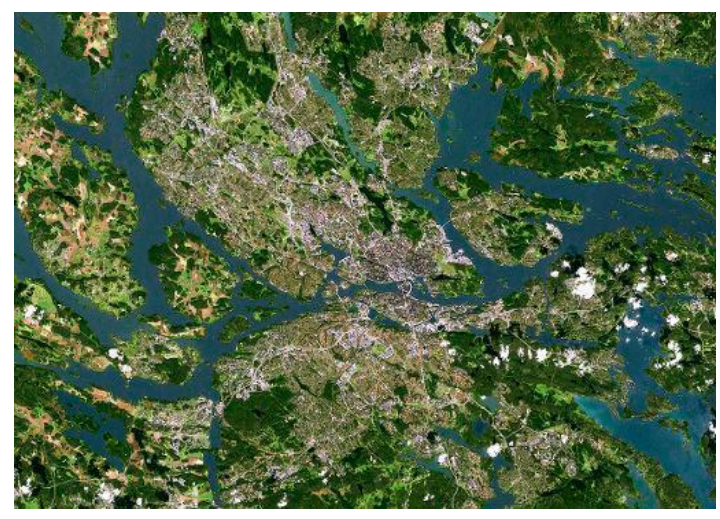

Figura 27- Imagem aérea de Estocolmo. Fonte: Parlamento Europeu (2009). Disponível em: < http://www.urban-hub.com/ptbr/urbanization/cinturoes-verdesencarecem-oumelhoram-as-cidades/>. Acesso em 2 fev. 2019

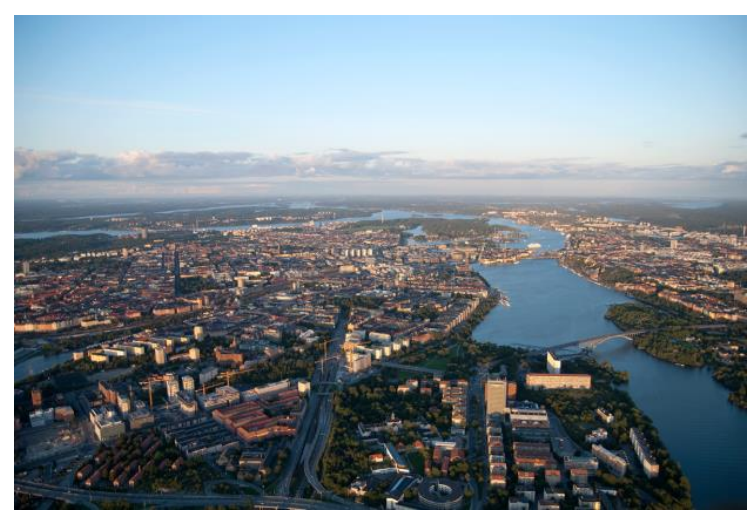

Figura 28- Vista aérea de Estocolmo. Fonte: Urban Hub (2017) Disponível em: <http://www.europarl.europa.eu/sides/getDoc. do? pubRef $=-/ /$ EP $/ /$ TEXT+|M- $>$. Acesso em 2 fev. 2019

Na escala intermediária, a infraestrutura verde se apresenta integrada à estrutura urbana interna da cidade e funciona como um sistema de espaços verdes públicos que integram várias funções como mobilidade, proteção do patrimônio histórico e recreação.

\footnotetext{
${ }^{5}$ Projeto desenvolvido pela Comissão Europeia com o objetivo de distinguir anualmente uma cidade europeia pelo seu desempenho ambiental. Disponível em: < http://www.europarl.europa.eu/sides/getDoc.do?pubRef=-//EP//TEXT + IM-

PRESS +20090302STO50551+0+DOC+XML+V0//PT>
} 


\section{Parque natural Südgelände (Berlim, Alemanha)}

Como exemplo desse tipo de aplicação, é possível citar o parque natural Südgelände, localizado no sul de Berlim, na Alemanha. Localizado em uma área residual ferroviária inutilizada por muitos anos, o parque ecológico multifuncional foi fruto de uma ação dos próprios residentes em virtude de um plano de desenvolvimento mobiliário planejado pelo governo para a área. No decorrer dos anos, as árvores ocuparam os trilhos e formaram florestas em alguns trechos e em outras pradarias, formada por gramíneas. Assim, o projeto do parque foi executado de forma a conservar o patrimônio ecológico e históricocultural onde pode se observar um cenário dinâmico a partir da integração entre a intervenção da sociedade moderna e a regeneração ecológica.

Os caminhos foram configurados por meio de passarelas porosas que não interferem no solo e o arranjo dos espaços oferecem uma mistura de experiências a partir de elementos como túneis, escadas, mirantes bem como espaços de arte e exposição os quais possibilitam uma visão diversa da paisagem. Algumas partes construídas que já existiam no local foram utilizadas por artistas para fazerem grafite transformando os lugares em atrativos artísticos e culturais.

O parque é utilizado tanto por moradores quanto visitantes de outros lugares e cumpre com a manutenção de funções ecológicas importantes que colaboram para a resiliência e sustentabilidade de Berlim.

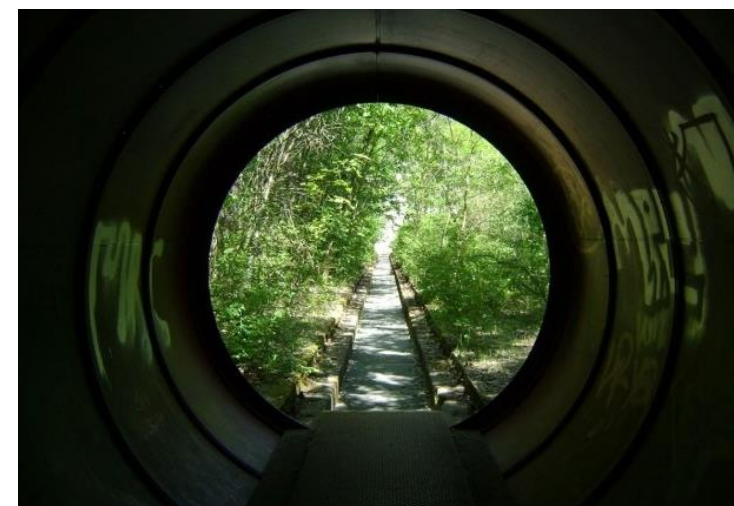

Figura 29- Túnel no Parque parque natural Südgelände. Fonte: SIQUEIRA (2011). Disponível em:

http://www.vitruvius.com.br/revistas/read/arqui teturismo/05.052/3937 >. Acesso em 2 de fev. 2019.

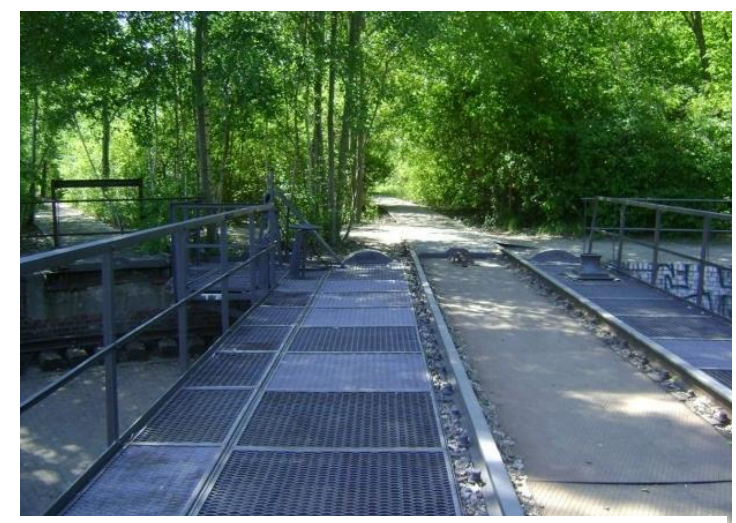

Figura 30- Caminho suspenso entre a floresta no parque natural Südgelände. Fonte: SIQUEIRA (2011). Disponível em: < http://www.vitruvius.com.br/revistas/read/arq uiteturismo/05.052/3937>. Acesso em 2 de fev. 2019. 


\section{Parque Bishan- Ang Mo Kio (Cingapura)}

Um exemplo da aplicação da infraestrutura verde ainda na escala intermediária foi a criação de um sistema de drenagem urbana sustentável no parque Bishan- Ang Mo Kio localizado em Cingapura. O projeto faz parte da iniciativa ABC Waters - Active, Beautiful, Clean Waters (ABC Água - ativa, bonita, limpa), uma iniciativa de longo prazo com o intuito de ampliar os corpos de água da Malásia em espaços novos e vibrantes, promovendo a recreação e a conexão da comunidade com a natureza.

O parque, que conta com mais de 3 milhões de visitantes anualmente, é um dos espaços verdes mais populares da cidade. O plano teve como objetivo inicial a melhoria da capacidade do Rio Kallang ao longo da borda do parque e, dessa forma, as intervenções foram feitas a fim de transformar o canal de concreto em um rio naturalizado - recuperando o ambiente natural, biodiversidade local e promovendo a recreação e conexão da comunidade com a natureza.

No local, um canal reto de drenagem de concreto com 2,7 km de extensão foi transformado em um rio natural sinuoso com $3,2 \mathrm{~km}$ de extensão que serpenteia o parque. Foram redesenhados 62 hectares de espaços verdes considerando os processos dinâmicos do sistema fluvial proporcionando diversos benefícios para os usuários do parque. Em ocasiões de chuva forte, o parque funciona como um canal de transporte, carregando a água a jusante. A velocidade do curso foi reduzida por meio do aumento da rugosidade do leito natural do rio com pedras de modo que menos partículas são transportadas rio abaixo. 


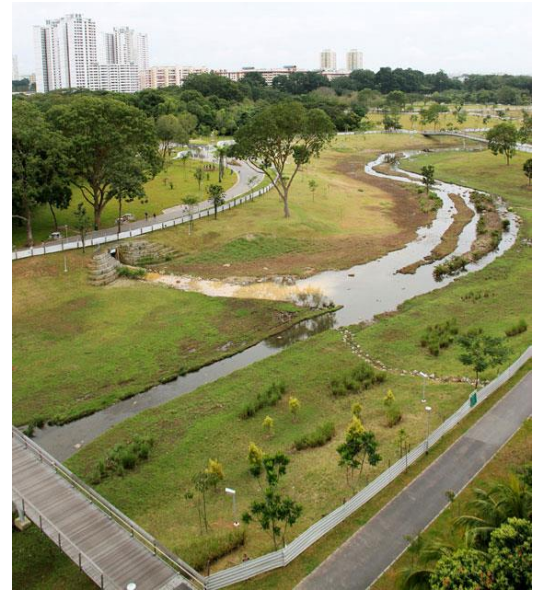

Figuras 31, 32 e 33-Parque Bisha Architecture. Disponível em: bishan-park-singapore-atelier-dreiseitl/\#.XTcRmvJKjIX. Acesso em 02 de ago. 2019.
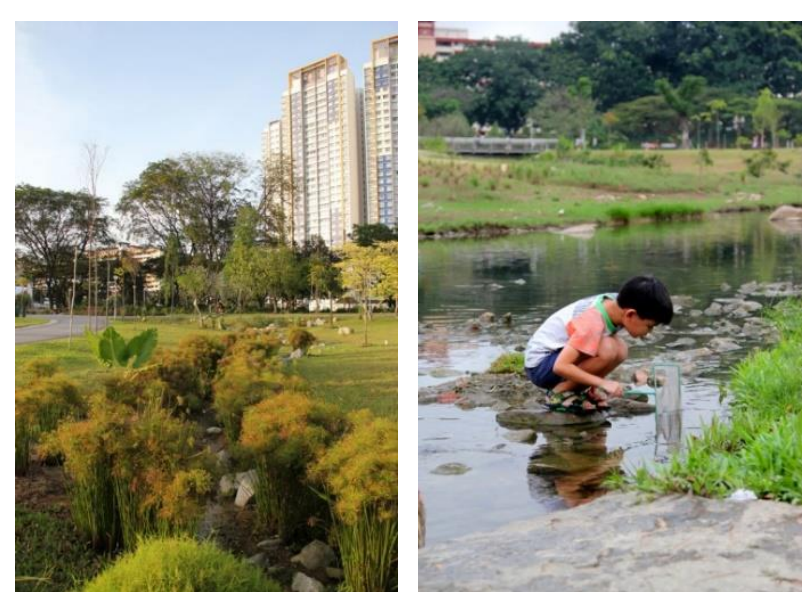

Blog World Landscape Anan- Ang Mo Kio. Fonte: Blog World Landscape
https://worldlandscapearchitect.com/kallang-river-

Medidas como o aumento da capacidade de transporte do rio aliado à diminuição da velocidade das águas proporcionaram a proteção contra inundações para as densas áreas do urbanas ao redor do parque. Além disso, o espaço criado oferece espaços para atividades recreativas e as margens do rio convidam as pessoas a se aproximarem da água.

A renaturalização do rio no parque contribuiu para a criação de uma enorme variedade de micro- habitats com um aumento da biodiversidade em 30\% bem como aumento da resiliência das espécies dentro do parque, o que significa o aumento das chances de sobrevivência alongo prazo. O Parque Bishan- Ang Mo Kio é um exemplo concreto de como um parque pode funcionar como uma infraestrutura ecológica por meio da combinação do manejo das águas, biodiversidade, recreação em espaços naturais e reaproximação das pessoas com o ambiente natural.

\section{Parque Chemin de I'île (Nanterre, França)}

Localizado em Nanterre, cidade vizinha de Paris, o parque Chemin de l'île percorre a borda do rio Sena e foi concebido como parte de um plano de revitalização urbana e despoluição do rio em 2006. O projeto teve como desafio principal a transformação de uma antiga área industrial a qual era cortada pelos 
viadutos de uma autoestrada que atravessa o rio Sena e por uma linha de trem (HERZOG, 2013).

A inovação do plano também está na incorporação das águas do rio com o objetivo de tratá-las e valorizar os processos naturais, com a criação de vários habitats e rica biodiversidade aquática e terrestre. Os mesmos jardins que são aproveitados por pessoas para recreação atuam também atuam como fitorremediadores ao receberem parte da água poluída do Sena. A água, ao passar pelas plantas fitorremediadoras, é aos poucos despoluída e adquire uma qualidade superior podendo ser utilizada para fins de irrigação. Em épocas do ano quando o índice de poluição aumenta, a água tratada retorna para o rio com o intuito de aumentar o índice de oxigênio dissolvido e assim evitando a morte de peixes. Localizado em uma região metropolitana, tem função importante também nas épocas de grandes chuvas uma vez que atua como um reservatório e evita transtornos de inundação nas áreas urbanizadas (HERZOG, 2013).

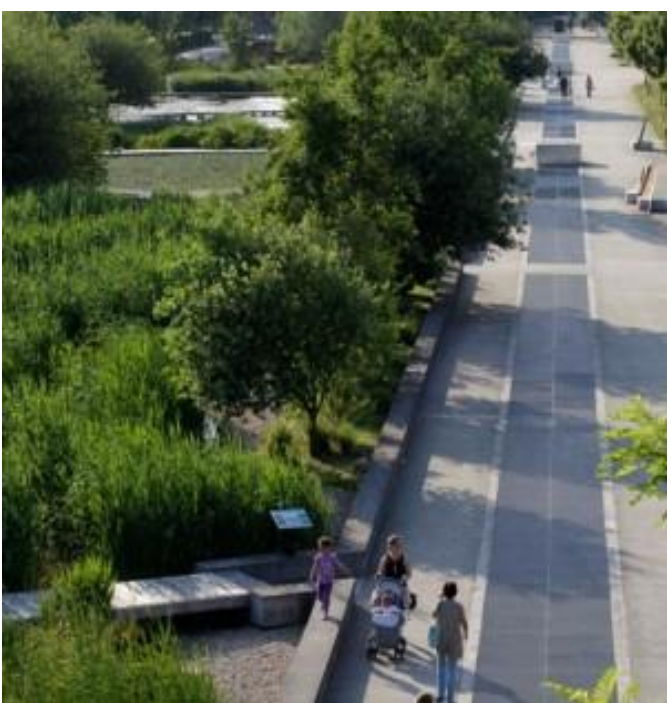

Figura 34- Parque Chemin de l'Île. Fonte: Site Landezine. Disponível em:

<http://landezine.com/index.php/2015/10 /le-parc-du-chemin-de-lile-bymutabilis/>.Acesso em 02 de ago. 2019.

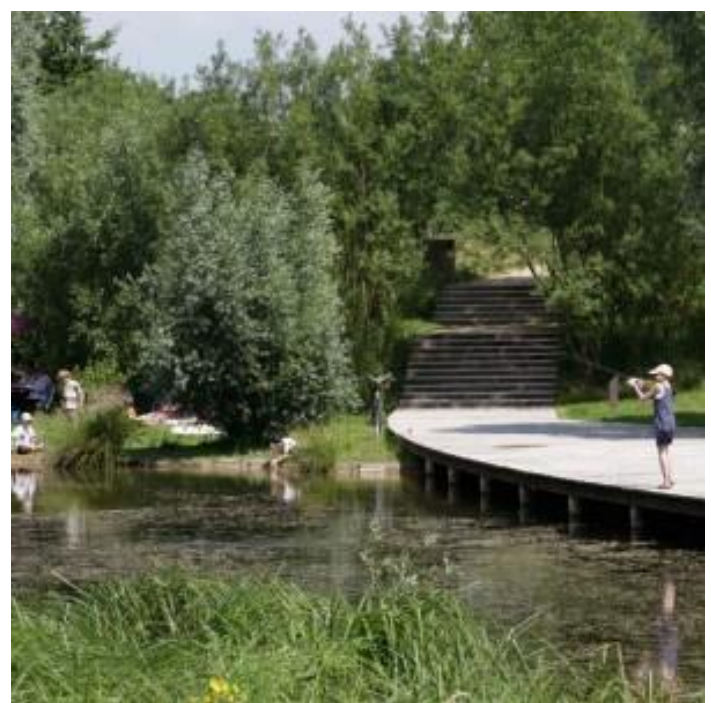

Figura 35- Parque Chemin de l'Île. Fonte: Site Landezine. Disponível em:< http://landezine.com/index.php/2015/10/leparc-du-chemin-de-lile-bymutabilis/>.Acesso em 02 de ago. 2019.

Seguindo ao longo do rio existem também áreas de cultivo agrícola, destinadas à população local e que podem ser alugadas por um valor simbólico. Os inquilinos, além de cultivarem o solo, também conseguem desenvolver relações sociais, com as fontes de alimento e com a natureza. 
Já na pequena escala, a infraestrutura verde é aplicada como uma estrutura que define o desenvolvimento urbano e que pode ser utilizada como uma diretriz de projetos de lotes específicos. Tipologias como jardins de chuva, canteiros pluviais, pisos drenantes, biovaletas, cisternas e tetos verdes são alguns exemplos de infraestrutura verde nesta escala (BONZI, 2017; YU, 2006).

Dentre os benefícios que a infraestrutura verde proporciona por meio da implantação de tipologias em escala local, estão: infiltração, detenção e retenção das chuvas no local; filtragem da águas de escoamento superficial contaminadas; aumento da permeabilidade do solo com redução de enchentes; proteção e criação de habitats para a biodiversidade; mitigação das ilhas de calor; criação de espaços para circulação de pedestres e ciclistas em ambientes sombreados; redução da circulação de veículos por meio de medidas de traffic calming, contenção de encostas e margens de cursos d'água evitando assoreamentos e deslizamentos, entre outros. Tais tipologias podem ser utilizadas em áreas urbanizadas e projetadas na escala local desde que projetadas com as especificidades de cada situação (HERZOG, 2013).

\section{Alagados construídos}

Consistem em áreas inundadas que armazenam as águas pluviais e realizam a retenção e remoção de contaminantes. Atuam no aumento da umidade do ar por meio da evaporação e evapotranspiração, criando importantes habitats para a fauna aquática a avifauna além de atuarem na captação do carbono e conforto térmico. Ao armazenarem o escoamento superficial e realizarem a limpeza da poluição difusa, atuam como verdadeiras esponjas que absorvem o excesso de escoamento das águas pluviais diminuindo a probabilidade de enchentes. Os alagados construídos também oferecem locais agradáveis junto à natureza com grande potencial para a educação e conscientização (HERZOG, 2013). 


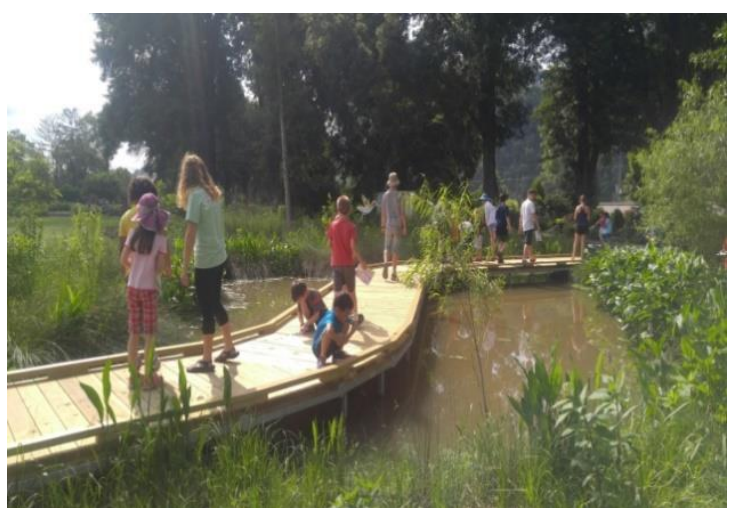

Figura 36- Alagado construído no Parque UT Gardens, na cidade de Knoxville (EUA). Fonte: The University of Tennessee, Knowville (2018). Disponível em: Disponível em: <https://environment.utk.edu/2018/05/22/wet lands-boardwalk-installed-at-ut gardens/>. Acesso em 12 de fev. 2019.

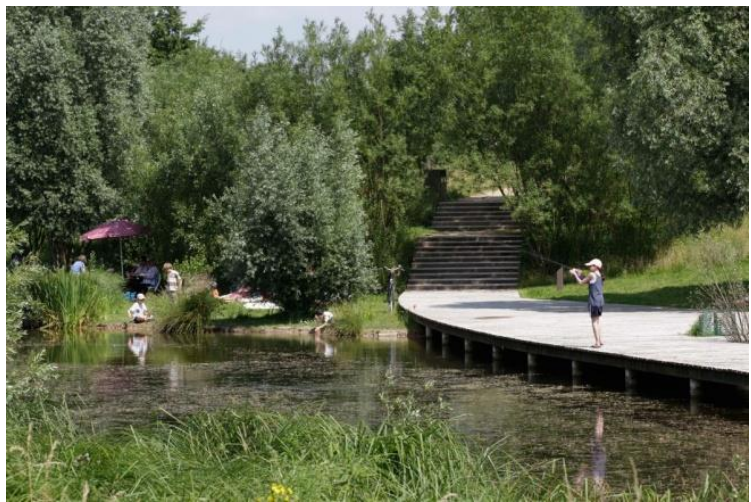

Figura 37- Alagado construído no parque Chémim d' ÎLe, em Nanterre, na região metropolitana de Paris. Fonte: Landezine Media. Disponível em: <http://www.landezine.com/index.php/2015/10 /le-parc-du-chemin-de-lile-bymutabilis/>. Acesso em 12 de fev. 2019.

\section{Biovaletas}

Biovaletas ou valetas de biorretenção vegetadas são depressões lineares preenchidas por vegetação, solo e outros elementos filtrantes situadas nas cotas mais baixas. Atuam na coleta, transporte e redução dos poluentes do escoamento superficial das águas pluviais. Essas tipologias podem ser implantadas ao longo de vias e estacionamentos e recebem águas contaminadas por óleos, borracha de pneus ou outros poluentes (CORMIER E PELLEGRINO, 2008). 


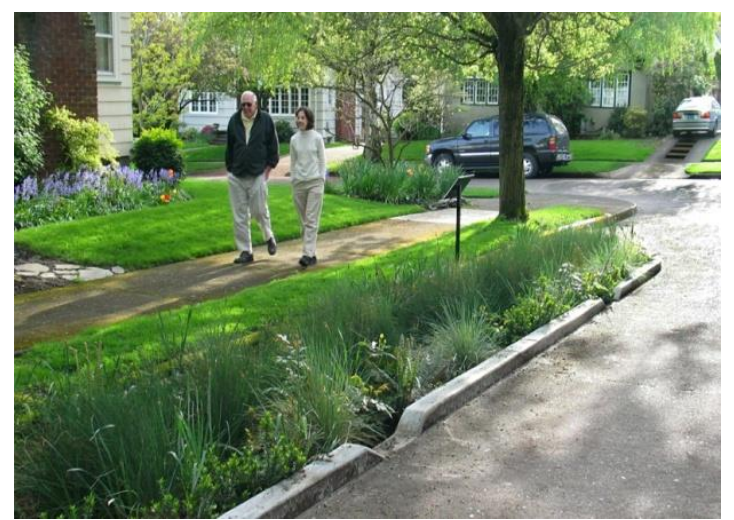

Figura 38- Biovaleta na cidade de Portland (EUA). Fonte: American Society of Landscape Architects. Disponível <https://www.asla.org/bioswales.aspx>. Acesso em 17 de fev. 2019.

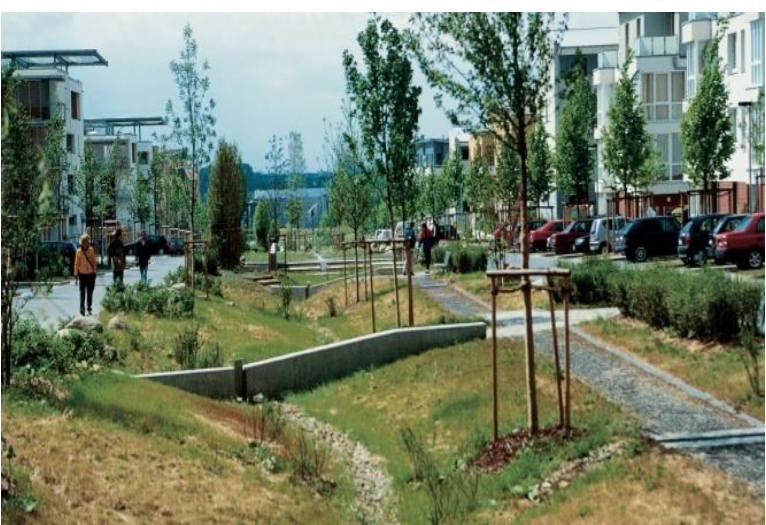

Figura 39- Biovaleta em Hannover, Alemanha. Fonte: Urban green- blue grids. Disponível em:<https://www.urbangreenbluegrids.com/mea sures/bioswales/ >. Acesso em 18 de fev. 2019.

\section{Jardins de chuva}

Os jardins de chuva são depressões topográficas que possuem a função de receber as águas da chuva de superfícies impermeáveis ou proveniente de telhados. O solo desse tipo de jardim é em geral tratado com compostos que aumentam a porosidade o que proporciona a absorção da água além de possuírem também micro-organismos e bactérias que ajudam na filtragem dos poluentes. As plantas desses espaços atuam também na evaporação e remoção da poluição das águas. Outros benefícios oferecidos ao meio urbano por meio dessa tipologia são: diminuição do escoamento superficial, detenção das águas pluviais, biodiversidade, moderação da ilha de calor, evaporação, captura de carbono, entre outros (HERZOG, 2013). 


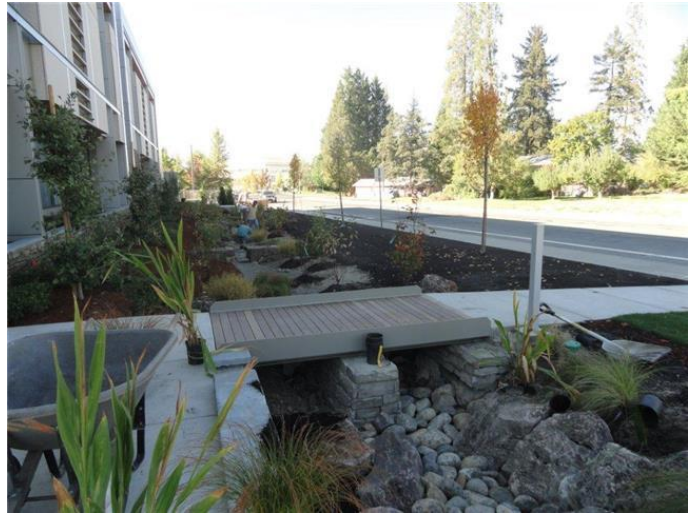

Figura 40- Jardim de chuva em Portland, EUA. Fonte: Jornal Brasil Online. Disponível em:

<https://jornalbrasil.com.br/noticia/depoisdos-parklets-os-jardins-de-chuva.html>. Acesso em 04 de fev. 2019.

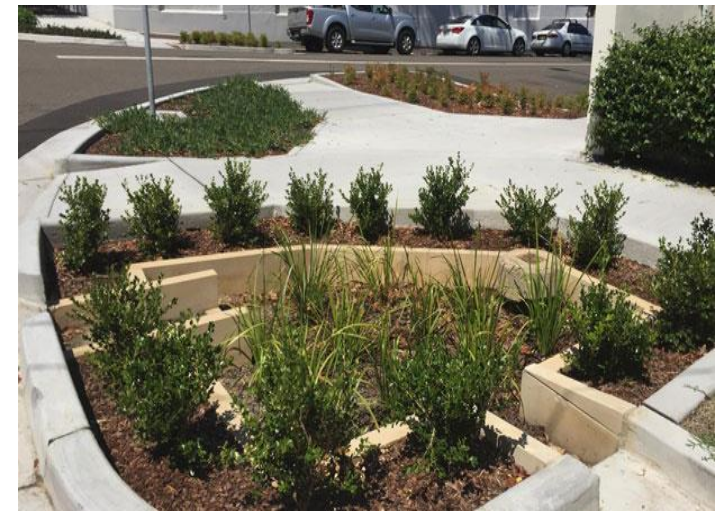

Figura 41- Jardim de chuva em Sydney, Austrália. Fonte: Site Ciclovivo. Disponível em: $<$ https://ciclovivo.com.br/arqurb/urbanismo/sydney-jardins-de-chuva/>. Acesso em 04 de fev. 2019.

\section{Canteiros Pluviais}

Os canteiros pluviais são jardins de chuva menores que os jardins de chuva, compactados em pequenos espaços urbanos como ruas, residências, edifícios que recebem águas do escoamento superficial e de áreas permeáveis. Além da sua capacidade de infiltração, os canteiros pluviais podem contar com um extravasador ou, em modelos sem infiltração, pode contar só com as funções de evaporação, evapotranspiração e transbordamento. Entre seus outros benefícios estão: redução, retenção e filtragem preliminar de água, diminuição do escoamento superficial, detenção de águas pluviais, moderação da ilha de calor, captura de carbono, entre outros (HERZOG, 2013; CORMIER E PELLEGRINO, 2008). 


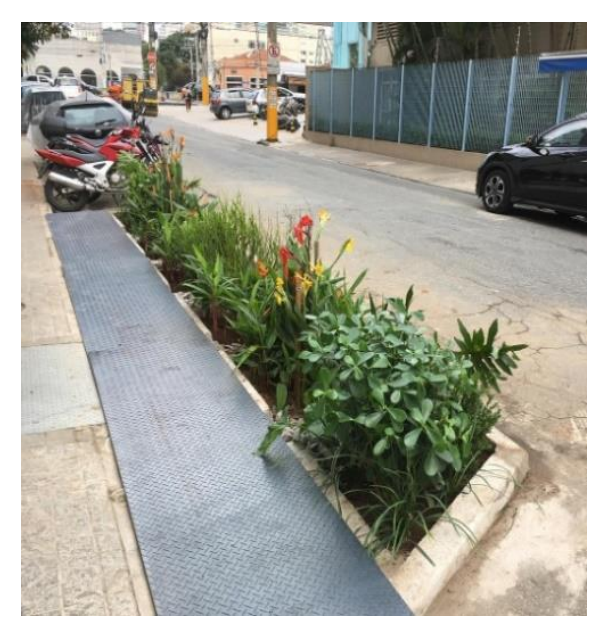

Figura 42- Canteiro em Moema, São Paulo (SP). Fonte: Site Ciclovivo. Disponível em: <Disponível em: https://ciclovivo.com.br/mao-namassa/permacultura/jardins-dechuva->. Acesso em 04 de fev. 2019

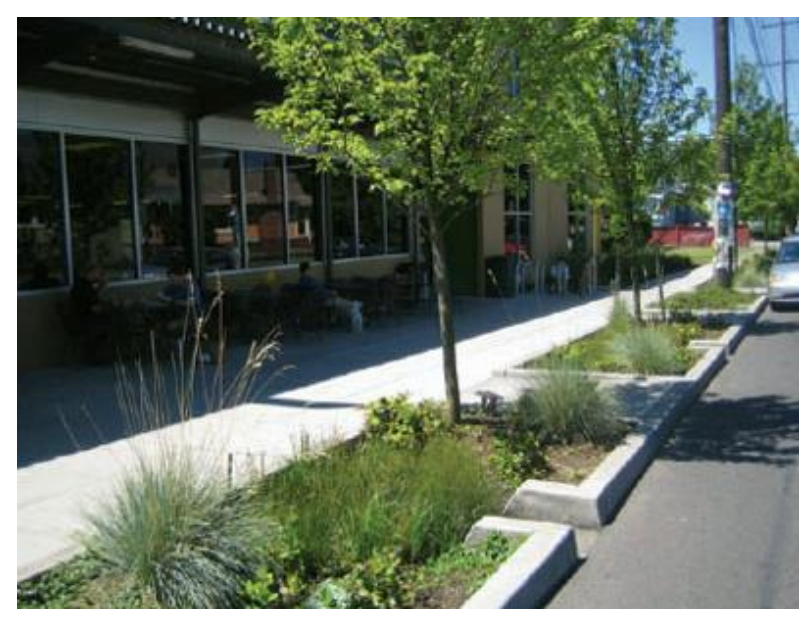

Figura 43- Canteiros pluviais em Portland, EUA. Fonte: Cormier (2008). Disponível em: <http://www.espiral.fau.usp.br/arquivosartigos/2008-Nate\&Paulo.pdf>. Acesso em 04 de fev. 2019

\section{Arborização Urbana}

A arborização consiste em um dos elementos mais importantes para a formação de uma infraestrutura verde em áreas urbanas e desempenham uma gama de benefícios que atendem tanto o meio natural quanto as pessoas. Ao exercerem processos físicos e biológicos de suma importância, atuam na manutenção da vida (HOUGH, 1984).

As ruas verdes são capazes de reduzir o escoamento superficial ao longo dos períodos de chuvas, amenizar a poluição advinda das áreas impermeabilizadas e atuar na melhoria da qualidade do ar e amenização das ilhas de calor ${ }^{6}$. Essa tipologia atua na conexão da flora e fauna e em processos relativos ao ciclo hidrológico, na medida em que possibilitam a infiltração das águas da chuva e absorvem parte das águas por meio do processo de evapotranspiração (HERZOG, 2010; HERZOG, 2013). A arborização urbana também proporciona

\footnotetext{
${ }^{6}$ Os autores Grey e Deneke (1978) e Schubert (1979) constatam que, apesar de uma árvore sozinha não afetar uma área em termos climáticos, um grupo de árvores é capaz proporcionar efeitos na temperatura. A folhagem da vegetação intercepta, reflete e absorve radiação solar, de forma a melhorar a temperatura do ar no ambiente urbano (MILANO; DALCIN, 2000).
} 
melhoria estética da paisagem com incentivo à prática de exercícios, impactando a saúde humana e o bem-estar social (MILANO e DALCIN, 2000; LOCATELLI et al., 2018).

\section{Tetos Verdes}

O termo "teto verde" é utilizado para denominar a utilização de cobertura vegetal que recobre lajes e telhados. A transformação dessas superfícies tradicionais em áreas vegetadas pode ser feita pela implantação de plantas suculentas ou até mesmo jardins suspensos como hortas e árvores frutíferas (BONZI, 2015).

São capazes de atuarem na recuperação de diversas funções da paisagem. Contribuem para o manejo das águas da chuva por meio da redução, retenção e filtragem das águas pluviais; reduzem a temperatura interna das edificações por meio do processo de evapotranspiração das plantas; implementam a oferta de biodiversidade nas áreas urbanas como avifauna e insetos além de atuarem na redução das ilhas de calor e captação de carbono (HERZOG, 2013).

\section{Cisternas}

Estrutura antiga feita com a finalidade de armazenar a águas da chuva para posterior reuso. No contexto da infraestrutura verde, a cisterna contribui para a redução do escoamento superficial e a água coletada por ser utilizada para regar jardins e hortas ou em qualquer outra atividade que não exija água potável (BONZI, 2015).

\section{Pavimento drenantes ou permeáveis}

Diz respeito ao conjunto de superfícies construídas que permitem a infiltração da das águas no solo como asfalto poroso, concreto permeável, materiais de demolição granulados, blocos intertravados, blocos vazados, paralelepípedos, brita e pedriscos, entre outros. São capazes também de realizar a filtragem e redução do escoamento superficial nas áreas urbanas (HERZOG, 2013; BONZI, 2015). 
INFRAESTRUTURA VERDE APLICADA AO ALTO E MÉDIO CURSO DO RIO TREMEMBÉ

CAPÍTULO II | A INFRAESTRUTURA VERDE

Com base nos exemplos de infraestrutura verde em diversas escalas descritos anteriormente, é possível afirmar que esse tipo de instrumento tem a capacidade de oferecer inúmeros benefícios não só no campo ambiental, como também social, econômico e cultural. Sua capacidade de adaptabilidade aos cenários urbanos diversos, confere a essa ferramenta uma solução plausível e possível de ser aplicada nas cidades, com funções indispensáveis para o melhor desempenho destas. 
INFRAESTRUTURA VERDE APLICADA AO ALTO E MÉDIO CURSO DO RIO TREMEMBPE

II SEÇÃO | A ÁREA DE ESTUDO 


\section{CAPITULOO 3}

\section{ANÁLISE TERRITORIAL DA PAISAGEM: CAMINHOS DO TREMEMBÉ}

Este capítulo apresenta os motivos que determinaram a escolha da área de estudo para o desenvolvimento da pesquisa e, a partir disto, apresenta uma análise das dinâmicas físicas e ambientais desta região de enfoque.

Diante da proximidade da área de interesse com a Serra da Cantareira, no primeiro momento apresenta-se este núcleo florestal enquanto unidade ambiental estrutural da metrópole de São Paulo com destaque para os seus serviços ambientais prestados. Em seguida, discute-se a Bacia Hidrográfica do Tremembé/ Ribeirão Piqueri enquanto parte da Zona de Amortecimento da Cantareira e que possui como elemento hídrico principal o Rio Tremembé. Partindo deste panorama, o trabalho conduz à uma aproximação na buffer zone de estudo que assume como eixo linear o alto e médio curso do Rio Tremembé, apresentando então seus aspectos relativos ao clima, vegetação, particularidades hídricas e de que maneira se revelam ao longo da geomorfologia, estrutura e fisiologia da paisagem.

\subsection{A SERRA DA CANTAREIRA COMO UNIDADE AMBIENTAL ESTRUTURAL DA METRÓPOLE DE SÃO PAULO}

As metrópoles podem ser definidas como aglomerações urbanas de extensão territorial e populações consideráveis. Esses grandes espaços enfrentam constantemente os desafios advindos de sua complexidade urbana, posto que abrangem diversas cidades com suas próprias características e múltiplas facetas. Dentre essas adversidades, o campo ambiental em especial tem proporcionado 
profundas preocupações, visto que uma parcela significativa dos municípios não possui um plano que guie o seu desenvolvimento urbano em harmonia com os aspetos ambientais, tecendo, assim, uma rede urbana que subestima questões fundamentais do meio ambiente (SCHUTZER, 2012).

$\mathrm{Na}$ realidade brasileira, as ações urbanas determinadas a focar na sustentabilidade ambiental se revelam também ainda bastante tímidas e ineficientes em várias cidades. Imersa em um campo metropolitano que pulsa dinamicidade e amplas trocas de matéria e energia, São Paulo é um exemplo de cidade brasileira que hoje enfrenta os efeitos do descompasso entre o progresso urbano e as características da sua paisagem natural.

Considerada a cidade mais populosa do Brasil, apresentou em 2017 uma população estimada de 12,1 milhões de habitantes (IBGE,2017) em uma área de aproximadamente $1.523 \mathrm{~km}^{2}$. Mais especificamente ao longo do século $X X$, suas políticas de planejamento enfatizaram as soluções monofuncionais a exemplo da construção de grandes obras viárias, dando prioridade para os veículos, ou intervenções de drenagem ao longo dos fundos de vale (FRANCO, 2019).

A paisagem natural da cidade cedeu espaço ao longo do tempo para a especulação imobiliária por meio da canalização dos rios e seus afluentes, aterramento das áreas úmidas ou impermeabilização das áreas verdes. Hoje, consequências dessas intervenções afetam, acima de tudo, as pessoas: sejam moradores ou aqueles que estão de passagem. Dentre os efeitos nocivos percebidos estão a poluição, excesso de impermeabilização, variações extremas de temperaturas ao longo do dia, verde escasso, ausência de contato com a natureza, aumento do índice de doenças e estresse (FRANCO, 2019).

Admitindo como ponto de partida esse cenário desafiador, torna-se cada vez mais importante a busca por intervenções urbanas que favoreçam e considerem as condições ambientais da cidade. Nesse escopo, Shutzer (2012), ao discutir os problemas enfrentados nas grandes áreas metropolitanas e os princípios ambientais que devem guiar possíveis intervenções nessas áreas, ressalta a necessidade de se identificar primeiramente a partir de uma macro 
escala unidades naturais que apresentam maior influência sobre aquelas condições ambientais locais.

Tendo em vista as diversas características e particularidades de cada território, esse reconhecimento funcionaria como primeiro indicador a orientar a intervenção territorial, guiada a partir de espaços mais influentes do ponto de vista da ação regeneradora e sustentabilidade ambiental. Nessa perspectiva, o autor analisa o espaço da metrópole paulistana e identifica aquelas unidades ambientais que estruturam a ação dos processos ao longo do território, em uma maior escala de abrangência.

Seguindo esse pensamento, Schutzer (2012) elegeu como tais unidades: a serra da Cantareira, as várzeas dos rios Tietê- Tamanduateí e Pinheiros, o Espigão Central e a serra do Mar. Nas palavras do autor, "essas unidades desempenham funções importantes no quadro ambiental e urbano da metrópole, influenciando parcelas significativas do território de modo direto ou indireto, ou sendo influenciadas por outras unidades" (SCHUTZER, 2012, p.185).

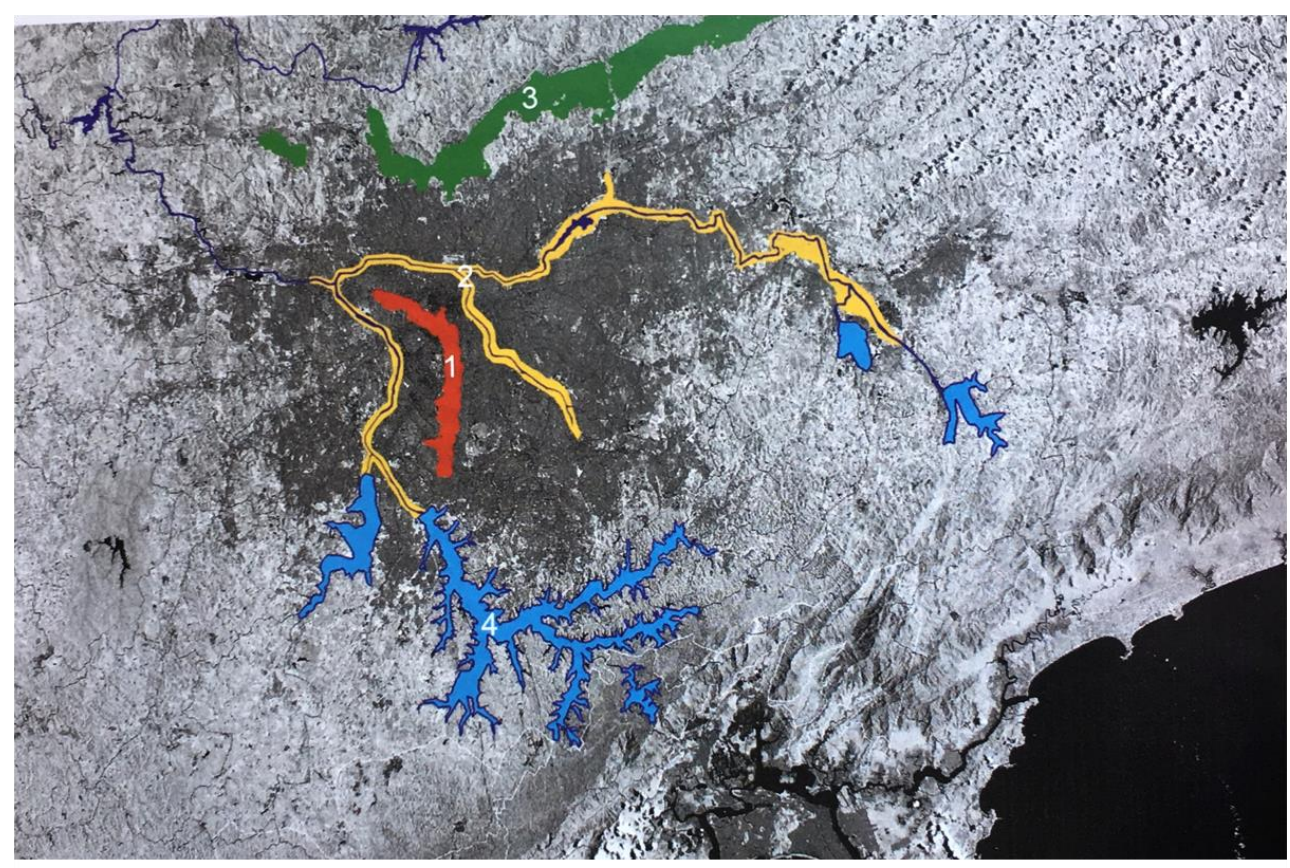

1- Espigão Central 2) Várzeas 3) Serra da Cantareira 4) Serra do Mar

Figura 44- Identificação das unidades ambientais estruturais presentes na metrópole de São Paulo. Fonte: Schutzer (2012). 
De acordo com Schutzer (2012), no contexto dessas unidades ambientais citadas, a Serra da Cantareira expande sua influência a uma maior parte da cidade. Esta unidade de conservação delimita a porção norte da mancha urbana e se estende ao longo dos territórios dos municípios de Perus até Guarulhos.

Assim, a Serra da Cantareira apresenta influência indireta sobre várias áreas da região metropolitana e compreende um território urbano de aproximadamente $400 \mathrm{~km}^{2}$ abrangendo toda a parcela norte da área metropolitana situada à margem direita do Tietê. Além disso, funciona como o principal divisor de águas da Bacia do Alto Tietê7 e a partir dela nascem diversos ribeirões o que the confere a atribuição de componente dispersor dos fluxos hídricos para outras seções de relevo da metrópole (SCHUTZER, 2012).

O papel da Serra da Cantareira enquanto unidade ambiental estrutural se justifica também por funcionar enquanto um moderador climático para grande parte da região metropolitana em razão da sua posição leste- oeste, forte presença de água e florestas, constituindo um importante remanescente da Mata Atlântica que abriga diversas espécies de animais e vegetais. A sua altitude fica a $300 \mathrm{~m}$ acima das cotas médias do sítio urbano da metrópole e tal posicionamento the concede uma interferência na circulação do ar o que resulta na amenização da temperatura e chuvas intensas nas proximidades (SCHUTZER, 2012).

Além disso, esta unidade também desempenha importante função como fonte de abastecimento de água para a região metropolitana por meio do sistema Cantareira. Nessas mesmas imediações percebem-se processos erosivos nas encostas e vales decorrentes da amplitude topográfica e declividades acentuadas dos terrenos (SCHUTZER, 2012).

Como reflexo dos esforços de proteção e tombamento da mata e mananciais da Serra da Cantareira, no final do século XIX, foi criado em 1963 o "Parque Estadual da Cantareira" que hoje se constitui como zona núcleo da

\footnotetext{
7"Praticamente a totalidade da Região Metropolitana de São Paulo (RMSP) está inserida dentro dos limites topográficos de uma única bacia, a Bacia do Alto Tietê (BAT)" (ABRIL, 2017, p.26).
} 
"Reserva da Biosfera do Cinturão Verde da Cidade de São Paulo"8. Esse parque Estadual se configura como a principal unidade de conservação da Serra da Cantareira e apresenta uma importância crucial tanto na produção de serviços ambientais ${ }^{9}$ quanto na proteção dos remanescentes da Mata Atlântica (Plano de Manejo do Parque Estadual da Cantareira, 2009). O Parque engloba parte na Bacia Hidrográfica do Tietê, apresenta 7.916,52 ha e 90,5 km de perímetro e abrange quatro municípios do Estado de São Paulo sendo eles: Mariporã, Caieiras, Guarulhos e São Paulo.

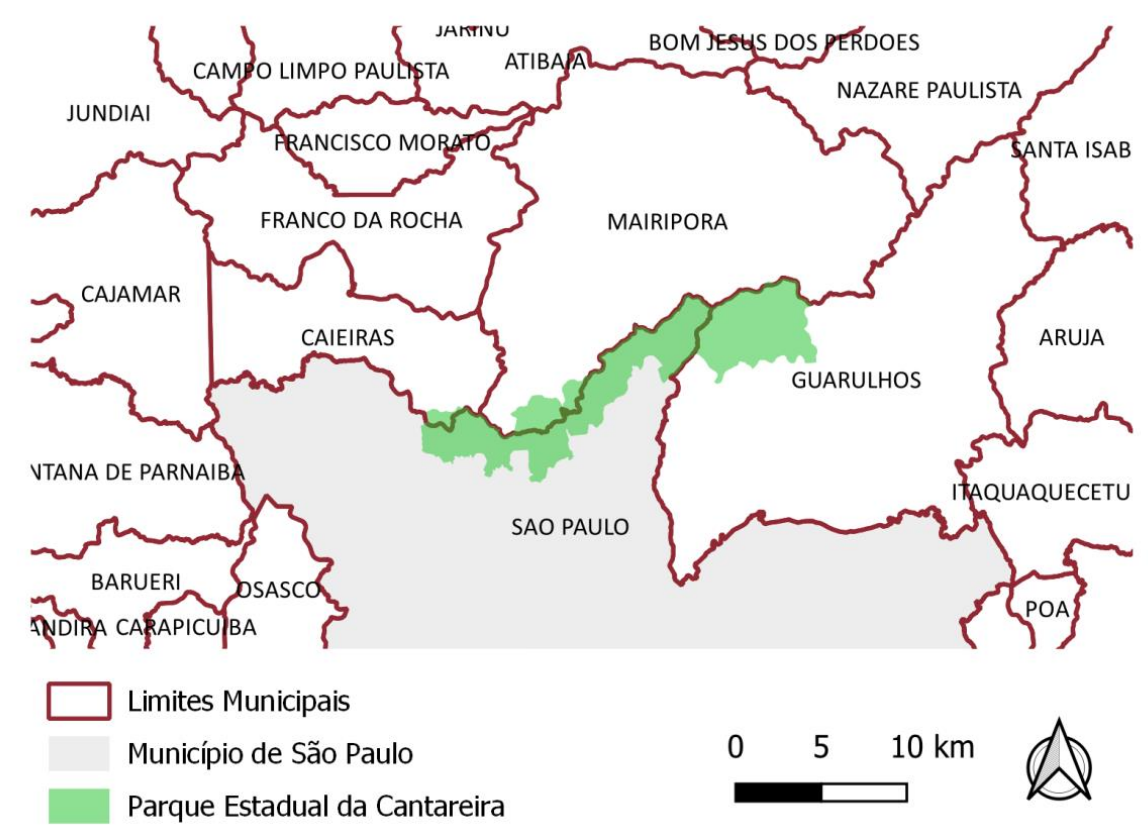

Figura 45- Extensão do Parque Estadual da Cantareira nos municípios do Estado de São Paulo. Fonte: Mapa Digital da Cidade de São Paulo com adaptações da autora.

\footnotetext{
8 "(...) criada em 1994, é figura de proteção ambiental reconhecida internacionalmente pela Organização das Nações Unidas para a Educação, a Ciência e a Cultura (UNESCO) e faz parte da Reserva da Biosfera da Mata Atlântica. Possui área de 1.611.710 hectares, compreende biomas de Mata Atlântica e de Cerrado e brange 73 municípios. Seu objetivo principal é conservar e restaurar a diversidade ecológica dos corredores ecológicos (LEITE, 2017,p.85).

9 O termo "serviços ambientais" aqui utilizado tem a mesmo sentido que "serviços ecossistêmicos", ou seja, "os benefícios que as pessoas obtém dos ecossistemas" ou então, "as funções oferecidas naturalmente pelos ecossistemas, mantidas, aprimoradas ou restauradas por ação do homem, visando a conservação de condições ambientais adequadas pela vida no Planeta".(URBAN BIODIVERSITY AND ECOSYSTEM SERVICES PROJECT - URBES. Factsheets, números 1 a 5. Disponível em: <http://uberproject.org/factsheets.html>. Acesso em; 15 out. 2019).

Essas funções oferecidas naturalmente pelos ecossistemas incluem processos que ocorrem naturalmente, como limpeza da água, decomposição de dejetos e sequestro de carbono (ADLER, 2015 p.369 citado por SCHUTZER, 2019).
} 


\subsection{JUSTIFICATIVA E DELIMITAÇÃO DA ÁREA DE ESTUDO}

Diante da relevância do Parque Estadual da Cantareira enquanto unidade de conservação e prestadora de serviços ambientais para a cidade de São Paulo, surgiu a intensão de estudar as relações estabelecidas entre o tecido urbano e essa grande mancha verde associada aos corpos hídricos e a outros fragmentos remanescentes da Mata Atlântica. Num contexto mais abrangente, elegeu-se como unidade de estudo a Bacia Hidrográfica do Tremembé/ Ribeirão Piqueri Tremembé localizada na cidade de São Paulo e que engloba parte da Zona de Amortecimento do Parque Estadual da Cantareira ${ }^{10}$.

No âmbito do município, existem ainda outras três bacias hidrográficas localizadas na Zona de Amortecimento, são elas: Ribeirão Engordador (ou Ribeirão Barrocada); Rio Cabuçu de Baixo e Ribeirão dos Perus.

\footnotetext{
${ }^{10}$ A Zona de Amortecimento do Parque Estadual da Cantareira determinada pelo seu Plano de Manejo (2009) foi elaborada com base no uso da terra desta unidade de conservação e instrumentos e leis voltados para aspectos ambientais e urbanos incidentes. A área delimitada tem como intuito preservar as áreas florestais remanescentes e recuperar os ambientes alterados, revertendo-se o quadro progressivo de isolamento desta unidade de conservação (SILVA et al., 2011, p.2). Dentre alguns dos objetivos estabelecidos para esta zona estão: proteção e recuperação dos remanescentes florestais e mananciais, integridade da paisagem por meio da recuperação e manutenção da biodiversidade, conectividade existente e do patrimônio histórico, étnico, e cultural com controle do uso do solo. Além disso, ressalta-se a produção da água para o maior manancial da Região Metropolitana de São Paulo como um importante serviço ecossistêmico prestado na região (SANDRE,2017).
} 


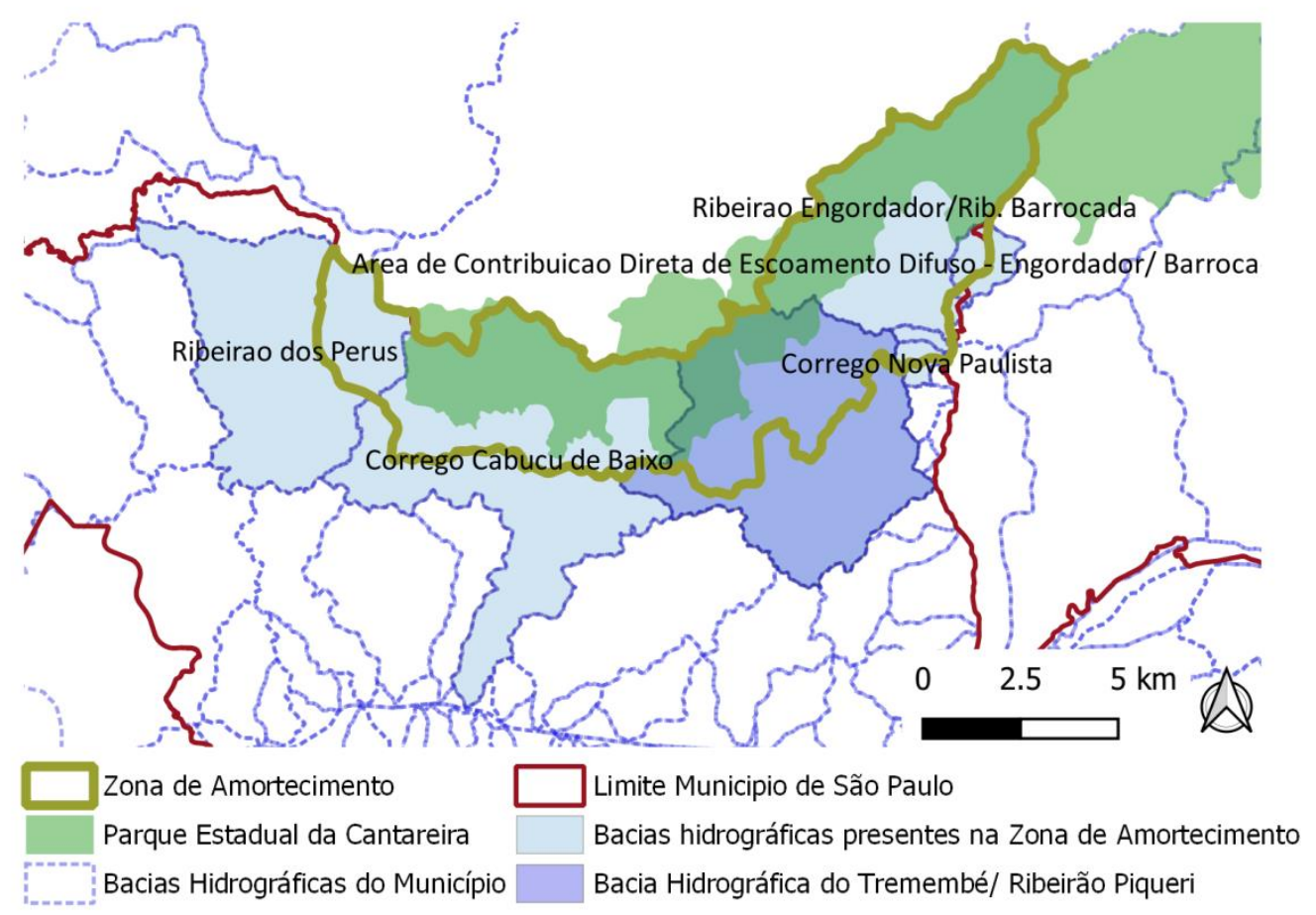

Figura 46- Bacias hidrográficas localizadas na Zona de Amortecimento do Parque Estadual da Cantareira. Fonte: Mapa Digital da Cidade de São Paulo com adaptações da autora.

O Rio Tremembé ${ }^{11}$, principal rio da bacia em questão, segue predominantemente na direção oeste- leste por uma extensão aproximada de $8,3 \mathrm{~km}$ até desaguar no rio Cabuçu de Cima. Este, por sua vez é o primeiro rio a desaguar diretamente no Rio Tietê, no município de São Paulo e faz divisa com o município de Guarulhos. A divisa da bacia hidrográfica do Tremembé é marcada

\footnotetext{
${ }^{11}$ Em alguns materiais icnográficos e mapas antigos, o canal de drenagem Tremembé geralmente é nomeado como "ribeirão" enquanto em outros o mesmo curso hídrico é intitulado como "rio". Este tipo de nomenclatura assume variações e não há uma referência exata ou correta do que deve ser utilizado, dado que seu uso provém de um uso cultural e antigo, associado apenas ao volume de água do curso. Ressalta-se que, a fim de eleger uma nomenclatura para este canal de drenagem, o presente trabalho se embasou na plataforma de dados Geosampa da Prefeitura de São Paulo que denomina o curso hídrico como de $4^{\mathrm{a}}$ ordem. O conceito de ordem é esclarecido no Manual Técnico de Geomorfologia (IBGE, 2009) no tópico hierarquia fluvial o qual aponta como referência o sistema de Horton (1945) modificado por Strahler (1952). De acordo com os autores, este sistema, "assume os canais sem tributários como os de primeira ordem, estendendose desde a nascente até a confluência; os de segunda ordem surgem da confluência de dois canais de primeira ordem e só recebem afluentes de primeira ordem; os canais de terceira ordem surgem da confluência de dois canais de segunda ordem, podendo receber afluentes de segunda e de primeira ordem, e assim sucessivamente". Seguindo este raciocínio, o curso hídrico Tremembé pode ser considerado como um canal de quarta ordem e é nomeado aqui como "rio" por ser considerado o mais extenso e principal curso d'água presente na Bacia Hidrográfica do Tremembé/ Ribeirão Piqueri.
} 
pela Rodovia Fernão Dias que interliga São Paulo e Minas Gerais, implantada na várzea do Rio Cabuçu (Ver figura 47). A figura 48 mostra as sub bacias que formam a Bacia Hidrográfica do Tremembé.

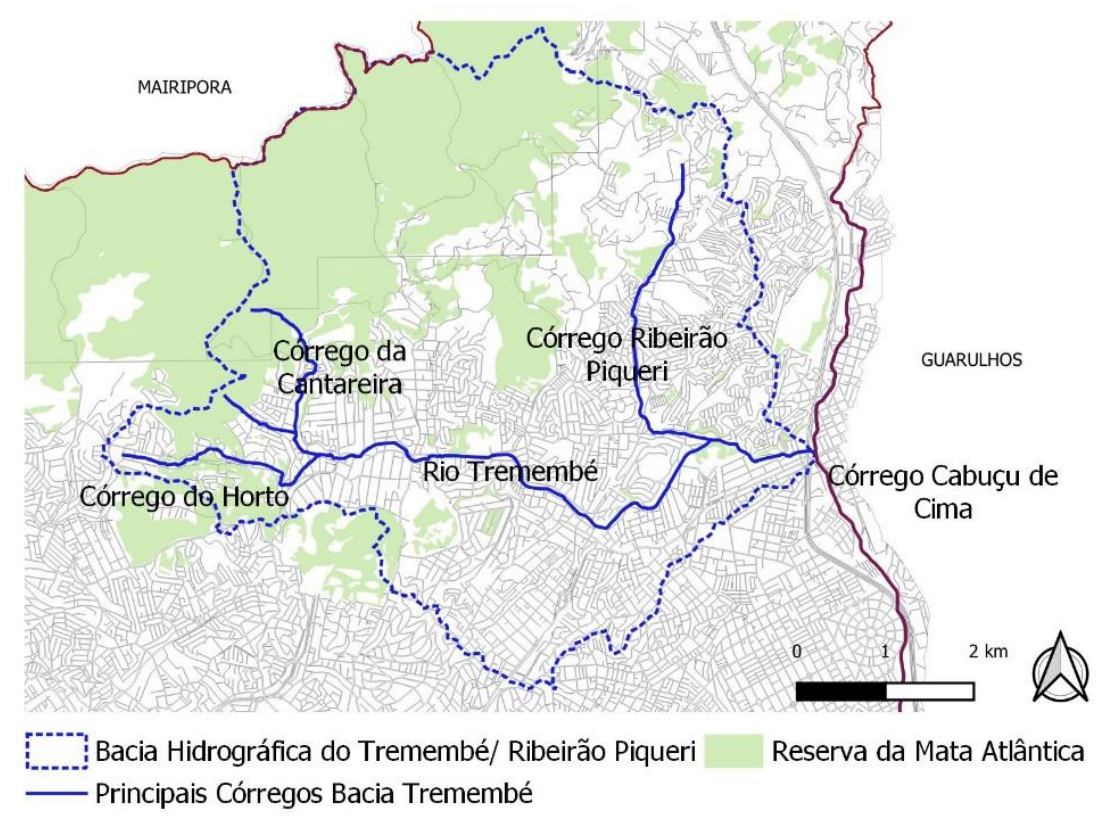

Figura 47- Bacia Hidrográfica do Tremembé e indicação dos seus principais córregos Fonte: Mapa Digital da Cidade de São Paulo com adaptações da autora.

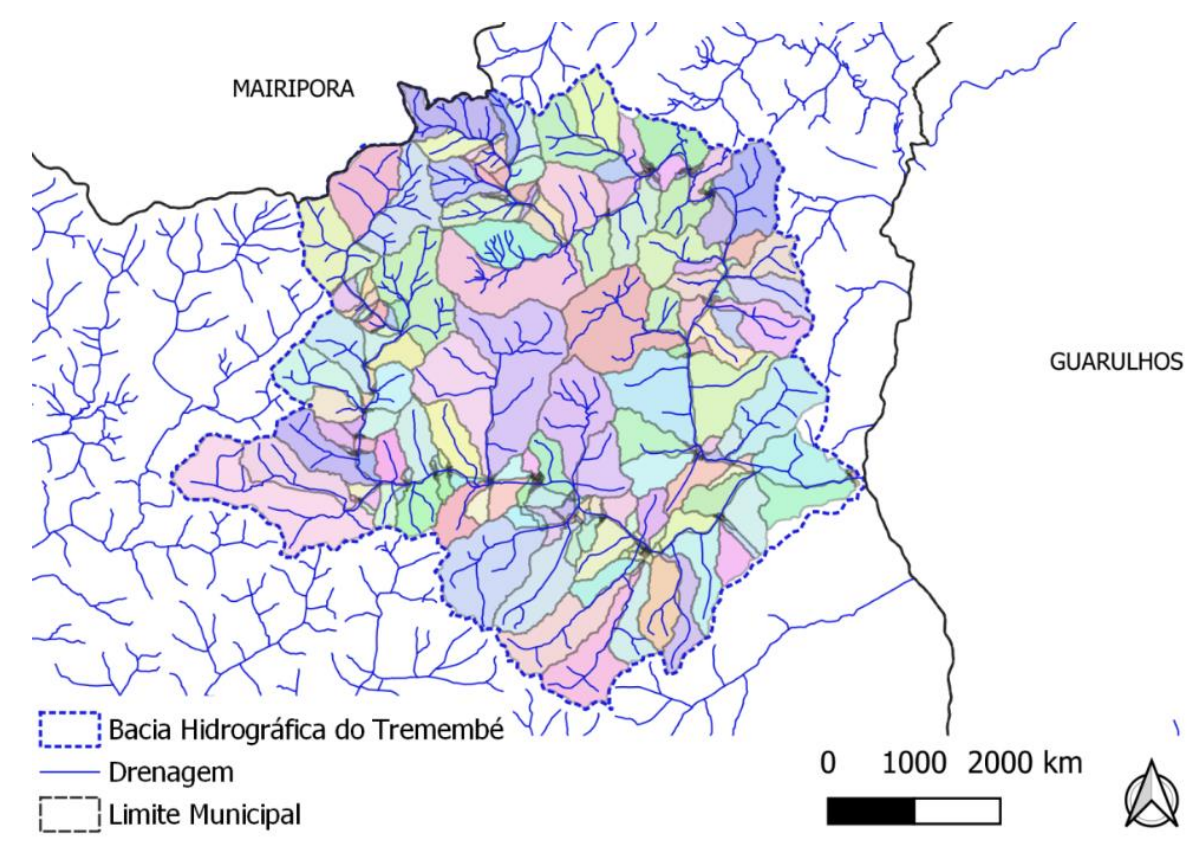

Figura 48- Bacia Hidrográfica do Tremembé e suas sub bacias constituintes. Fonte: Mapa Digital da Cidade de São Paulo com adaptações da autora. 
O principal rio da Bacia Hidrográfica Tremembé/ Ribeirão Piqueri apresenta sua nascente original nas intermediações do Parque Estadual da Cantareira e do Horto Florestal e conta com a contribuição de vários córregos, muitos deles hoje ocultos devido às intervenções urbanas realizadas.

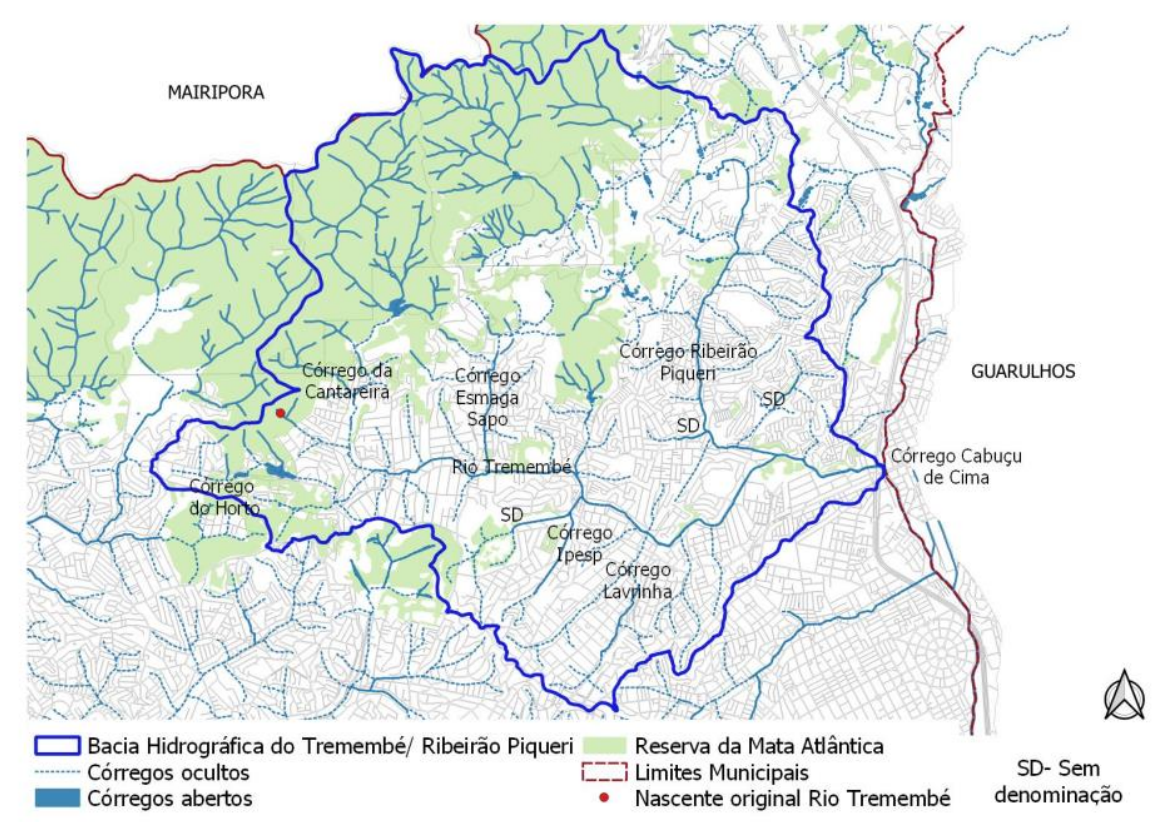

Figura 49- Bacia Hidrográfica do Tremembé/ Ribeirão Piqueri e indicação de todos os seus córregos abertos e ocultos. Fonte: Mapa Digital da Cidade de São Paulo com adaptações da autora

A área de estudo compreende o eixo que percorre desde a nascente original do Rio Tremembé, passando pelos respectivos pontos de confluência com os córregos Esmaga Sapo e Ipesp até alcançar a confluência com o córrego Lavrinha, na divisa administrativa como o distrito jaçanã. Esse eixo delimitado abrange o alto e médio curso do Rio Tremembé e compreende ainda uma zona de amortecimento de 500 metros para cada um dos lados, segundo critérios de caminhabilidade ${ }^{12}$. A área de influência é denominada também de buffer zone e abrange uma superfície de aproximadamente $5520000 \mathrm{~m}^{2}$ ou $5,52 \mathrm{~km}^{2}$.

\footnotetext{
12 "A distância aceitável de caminhada é um conceito relativamente fluido. Algumas pessoas andam felizes por muitos quilômetros, enquanto para alguns idosos, deficientes ou crianças, mesmo curtas caminhadas são difíceis. A maior parte das pessoas está disposta a percorrer 500 metros" (GEHL, 2013, p.221).
} 


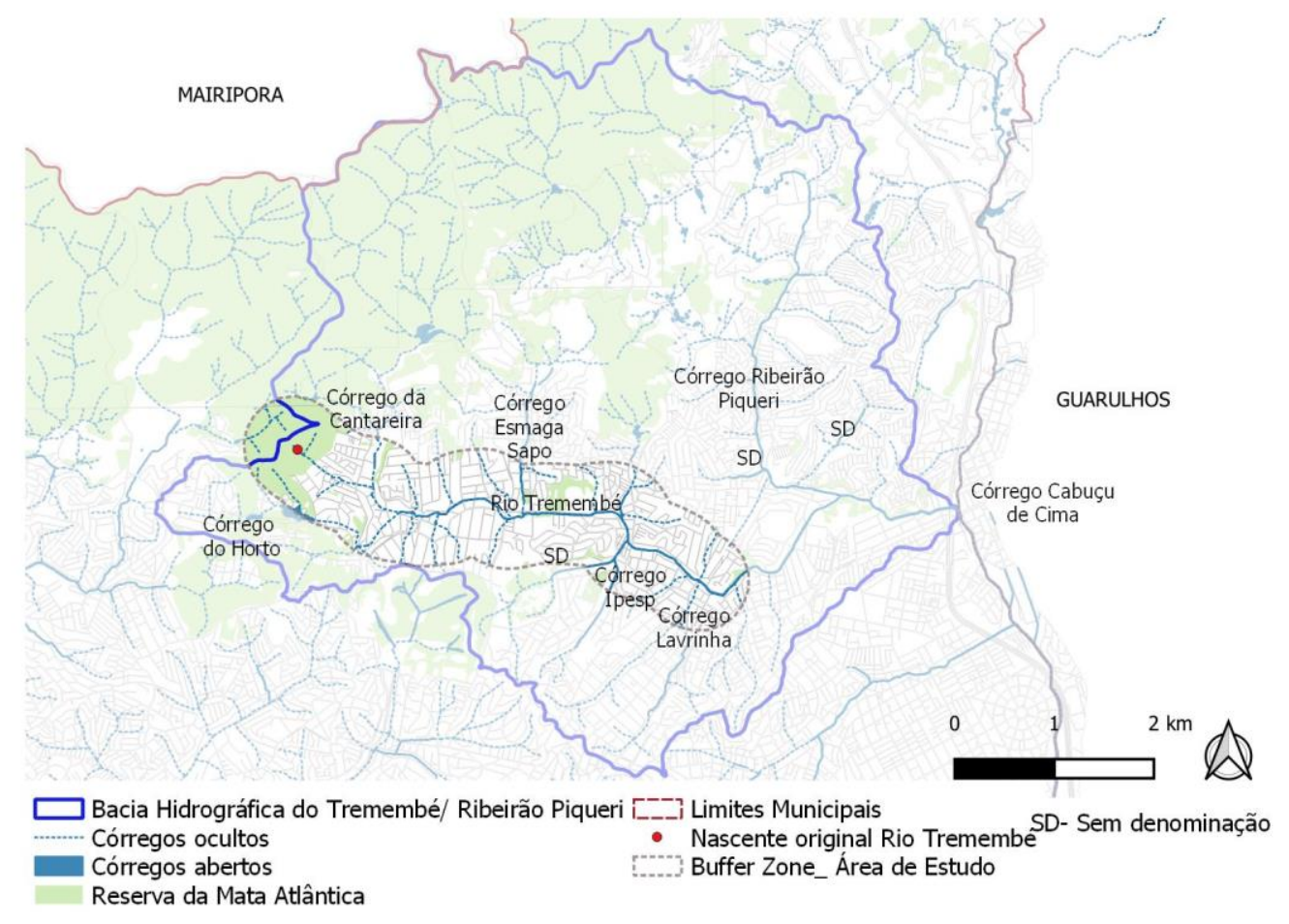

Figura 50- Localização da área de estudo na Bacia Hidrográfica do Rio Tremembé/ Ribeirão Piqueri com indicação da nascente original do Rio Tremembé Fonte: Mapa Digital da Cidade de São Paulo com adaptações.

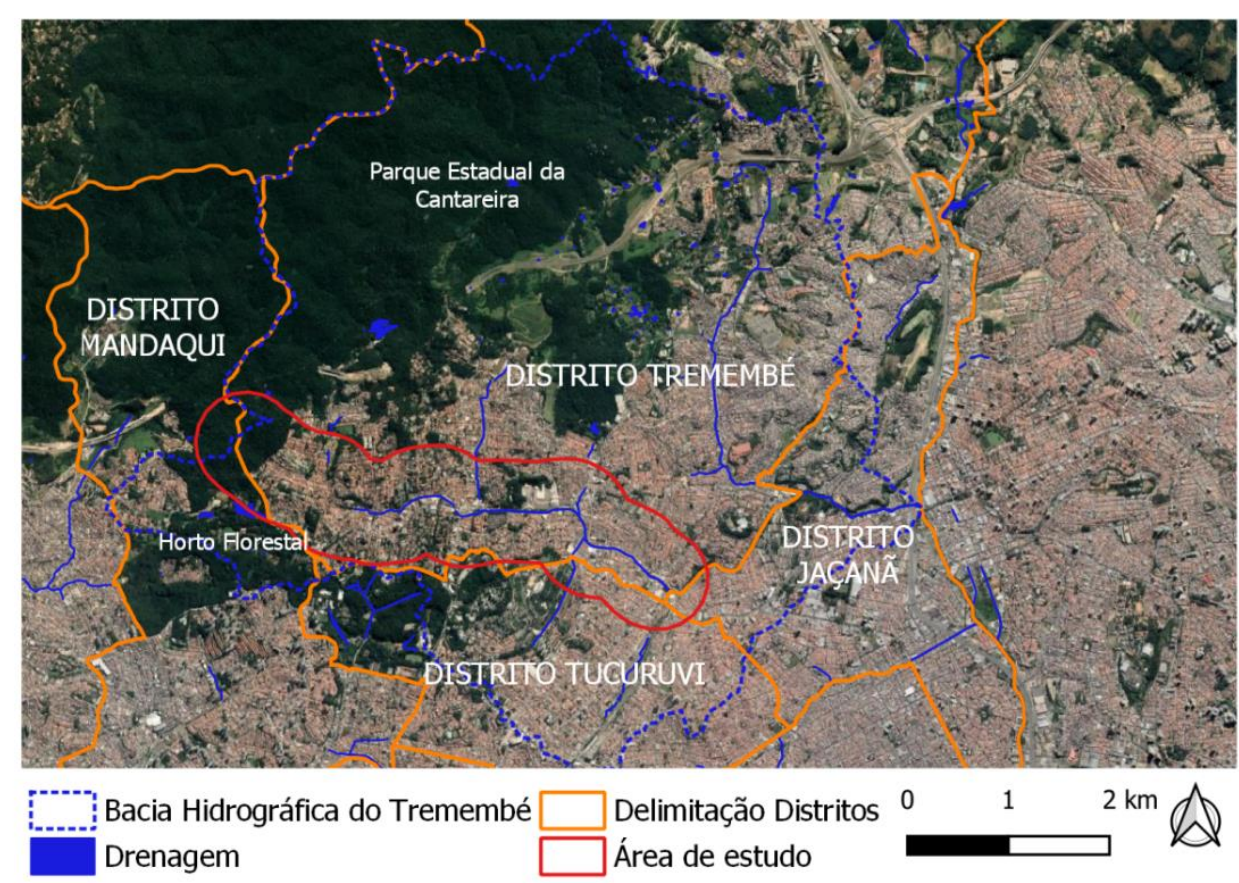

Figura 51- Localização da área de estudo com relação à Bacia Hidrográfica do Tremembé/ Ribeirão Piqueri e distritos da cidade de São Paulo (SP). Fonte: Mapa Digital da Cidade de São Paulo com adaptações 
A escolha por estudar essa região se justifica devido à manifestação de alguns conflitos entre as áreas ambientais sensíveis existentes e a compressão urbana cada vez mais intensa no entorno das áreas naturais. Dados do Atlas Ambiental do Município de São Paulo ${ }^{13}$ indicam que o avanço da mancha urbana sobre a Mata Atlântica foi marcante entre anos 1991 e 2000, período em que 5.345 ha de cobertura vegetal foram perdidos, cerca de 6,5\% da área verde da cidade. Desse montante, cerca de $22 \%$ ou 1.170 ha de todo o desmatamento aconteceu nos distritos entorno da Serra da Cantareira, o que evidencia a grande pressão que a região tem sofrido nas últimas décadas.

Apesar de ser formada por bairros consolidados, a área de influência determinada para esta pesquisa abriga grandes áreas vegetadas, remanescentes da Mata Atlântica, afloramento de alguns trechos do rio e córregos e proximidade com a matriz ecológica da Serra da Cantareira, o que the confere potencial como estudo no campo da ecologia da paisagem. A área em questão também abrange parte da Zona de Amortecimento do Parque Estadual da Cantareira e, por isso, apresenta especificidades relevantes no campo paisagístico e ambiental.

Além disso, esse trecho da bacia hidrográfica do Rio Tremembé/ Ribeirão Piqueri atualmente é palco de uma série de obras de drenagem com o objetivo de mitigar transtornos relacionados à drenagem das águas pluviais o que realça a sua importância como uma região propensa a receber princípios da infraestrutura verde. A motivação dessa pesquisa se pauta, portanto, na proposição de diretrizes que conciliem suas características naturais às suas particularidades urbanas, colaborando assim para a melhoria do cenário ambiental da área e contribuindo para a qualidade de vida dos moradores.

\footnotetext{
${ }^{13}$ Atlas Ambiental no Município de São Pulo - O Verde, O Território, O Ser Humano: Diagnóstico e Bases Para Políticas Públicas Para as Áreas Verdes no Município de São Paulo / Coordenação de Patrícia Marra Sepe e Harmi Takiya. - São Paulo: SVMA, 2004.
} 


\subsection{CARACTERÍSTICAS FÍSICO AMBIENTAIS}

Quando se trata de uma intervenção humana na paisagem, seja por arquitetos, engenheiros, geólogos, planejadores ou outros profissionais, é de extrema que importância que, antes de tudo, as características físicas e ambientais do espaço sejam identificadas e compreendidas. Por assumirem particularidades específicas e influências externas diversas, os processos da natureza são diferentes em cada espaço urbano, e, portanto, cada território demanda por soluções próprias e que não ofereçam riscos ou transtornos à população. O certo é que as interferências urbanas estão, a todo tempo, ligadas de alguma forma às condições naturais do sítio: a forma urbana e os meios de transporte podem interferir na qualidade do ar; as construções e grandes obras devem estar atentas às condições topográficas; a ocupação das várzeas ou nascentes dos rios podem ser responsáveis por enchentes e assim por diante.

Diante do elo inerente entre as condições naturais existentes e ações urbanas efetuadas, percebe-se que ideias de projeto eficientes e que obtêm êxito quando executadas foram aquelas que compreenderam e consideraram esta importante relação, ao passo que respeitaram os processos da natureza e assim garantiram a qualidade dos espaços urbanos.

Quando discorre sobre essa abordagem, Spirn (1995) cita o exemplo de algumas cidades que se adaptaram engenhosamente à natureza e que colheram como frutos bons resultados. Dentre elas então Stuttgart, na Alemanha, que utilizou seus espaços livres como canalização do ar fresco e limpo para o centro congestionado; Woodlands, no Texas, que aproveitou espaços livres, públicos e privados como um sistema de drenagem das águas pluviais o qual absorveu as cheias e preveniu enchentes nas cotas mais baixas e Boston que tirou proveito de suas várzeas a montante para o armazenamento das águas das cheias. A partir destas referências reais, percebe-se que, quando examinam e consideram os agentes naturais, as intervenções na paisagem podem contribuir para a segurança e a resiliência dos núcleos urbanos. 
Sobre a perspectiva da resiliência urbana das metrópoles brasileiras, o geógrafo Schutzer (2019) afirma que, apesar das questões ambientais estarem sendo aos poucos incorporadas aos projetos nos últimos tempos, as intervenções deste cunho ainda se mostram superficiais deixando de considerar devidamente a relação entre os processos naturais, a intervenção humana herdada até aquele momento e o impacto adicional do projeto em pauta. Sobre essa lacuna, o autor afirma que ainda existe uma tendência de se reconhecer o espaço urbano como um território de topografia neutra, isento de declividades e de serviços ambientais oferecidos por cada conjuntura morfológica da paisagem. Nesse enfoque, os planos em vigor ainda exibem soluções simplistas, parciais, que não consideram as dinâmicas da paisagem e a relação destas com o ambiente natural e construído (SCHUTZER 2012; SCHUTZER 2019).

Schutzer afirma que como forma de valorizar as condições ambientais e reestabelecer esse equilíbrio entre os processos naturais, urbanos e humanos é necessário voltar-se para as características fisiográficas e geomorfológicas da paisagem. Para tanto, o autor se baseia na metodologia abordada por Ab S'áber (1969), que trata das categorias de análise da geomorfologia e em que se estabelecem três conceitos: a compartimentação do relevo; a estrutura superficial da paisagem e a fisiologia da paisagem. A partir desta análise, é possível se estabelecer um zoneamento ambiental, que se trata de um mapeamento geomorfológico em vários níveis e indicará as potencialidades naturais e urbanas no âmbito da paisagem urbana ou regional (SCHUTZER 2012).

\subsubsection{CLIMA}

A porção da área de estudo em verde localizada nas mediações do Parque Estadual da Cantareira e do Parque Horto Florestal pertence à unidade climática natural do Clima Tropical Úmido Serrano da Cantareira- Jaraguá nos Maciços e Serras da face meridional da Cantareira e Jaraguá (Ver figura 52- II A1). Esse trecho apresenta fortes declividades com topos de morro e altitudes de 800 a 1200 metros, o que justifica seus elevados impactos pluviométricos anuais que 
variam de 1400 a $1590 \mathrm{~mm}$. Essa mesma área apresenta boa ventilação e dispersão dos poluentes com temperaturas médias anuais entre $19,3^{\circ}$ e $17,7^{\circ}$, máximas anuais entre $24,9^{\circ}$ e $23,3^{\circ}$ e mínimas anuais de $15,5^{\circ}$ a $13,9^{\circ}$ (ATLAS AMBIENTAL DE SÃO PAULO, 2000).

A continuidade da faixa de estudo segue pertencente, em sua grande maioria, à unidade climática natural de Clima Tropical Úmido de Altitude do Planalto Paulistano nas colinas intermediárias e morros baixos do além Tietê (Ver figura 52- I). Com situação topográfica intermediária entre as várzeas aluviais e topos de morro, apresenta altitudes entre 740 e 820 metros. A proximidade com os topos de morro da Cantareira e Jaraguá confere à esta unidade climática altos índices pluviométricos anuais que variam entre 1350 a 1580 mm bem como razoável dispersão de poluentes e acumulação noturna de frio. Apresenta temperaturas anuais médias de 19,6 a $19,3^{\circ}$, máximas de $25,2^{\circ}$ a $24,9^{\circ}$ e mínimas entre $15,8^{\circ}$ a $15,5^{\circ}$ (ATLAS AMBIENTAL DE SÃO PAULO, 2004).

Uma outra parte bem menor da área de estudo, localizada na direção sudeste, pertence à unidade climática natural de altitude do Planalto Paulistano nas várzeas e baixos terraços do Vale Cabuçu de Cima (Ver figura 52- I C6). Possui altitudes menores, as quais variam entre 720 e 740 metros com índice de pluviosidade anual de 1560 a 1500. Com elevada estabilidade atmosférica noturna e matinal, a área em questão possui temperaturas anuais médias de $19,7^{\circ}$ a $19,6^{\circ}$, máximas de $25,3^{\circ}$ e $25,2^{\circ}$ e mínimas entre $15,9^{\circ}$ e $15,8^{\circ}$ com dispersão ruim de poluentes (ATLAS AMBIENTAL DO MUNICÍPIO DE SÃO PAULO, 2004). 


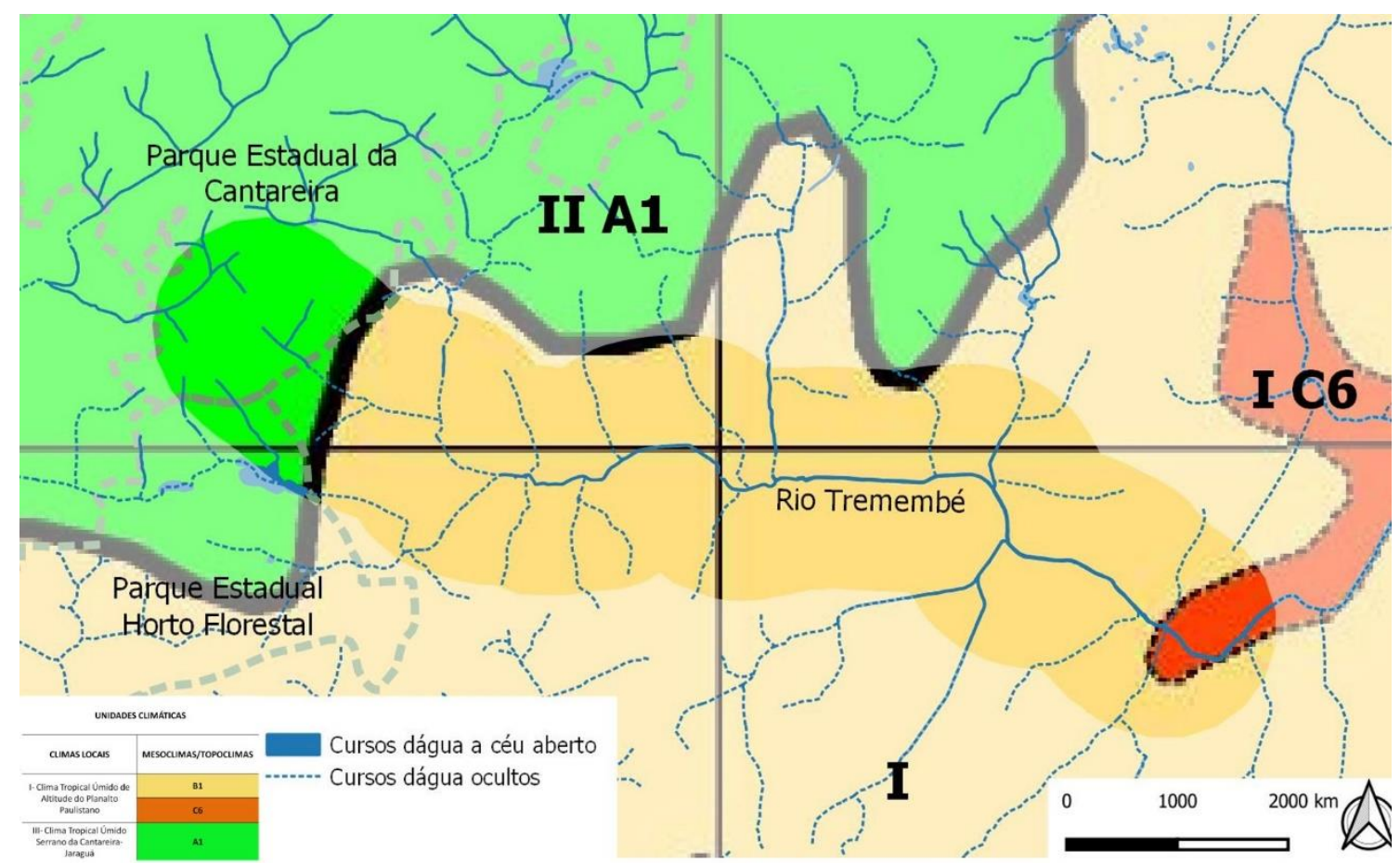

Figura 52- Mapa das unidades naturais climáticas do Atlas Ambiental de São Paulo com destaque para a buffer zone que correspondente à área de estudo. Fonte: Trabalho da autora sobre imagem do Atlas Ambiental.

\subsubsection{COBERTURA VEGETAL}

O entorno da buffer zone da área de estudo conta com a presença de notáveis áreas vegetadas pertencentes ao Parque Estadual da Cantareira, Parque do Horto Florestal, Invernada da Polícia Militar e Parque Lions Clube Tucuruvi. De acordo com o mapa de distribuição da vegetação do Atlas Ambiental do Município de São Paulo, essas unidades pertencem à classe de vegetação tipo I que abrange parques e bosques urbanos e classe de vegetação tipo 2, que diz respeito à zona rural incluindo Mata, Reflorestamento e Agricultura.

Ao direcionar o enfoque para o interior da faixa de estudo, esta engloba vegetação remanescente da Mata Atlântica na sua porção inicial e mais adiante, ao longo do seu curso, abrange também alguns outros menores fragmentos referentes à parques e bosques urbanos. A partir do início do curso do Rio Tremembé, parcela significativa da área possui densa urbanização e escassez de vegetação (classe urbano 2) e algumas destas mesmas áreas estão envoltas por 
regiões intensamente arborizadas e bairros jardins (classe urbano 3). A porção final da buffer zone está conforma mais uma vez na classe urbano 2 e, também, pela classe urbano 1, esta última marcada por regiões com escassez de vegetação, grande quantidade de prédios, vias pouco arborizadas e carência de praças e jardins.
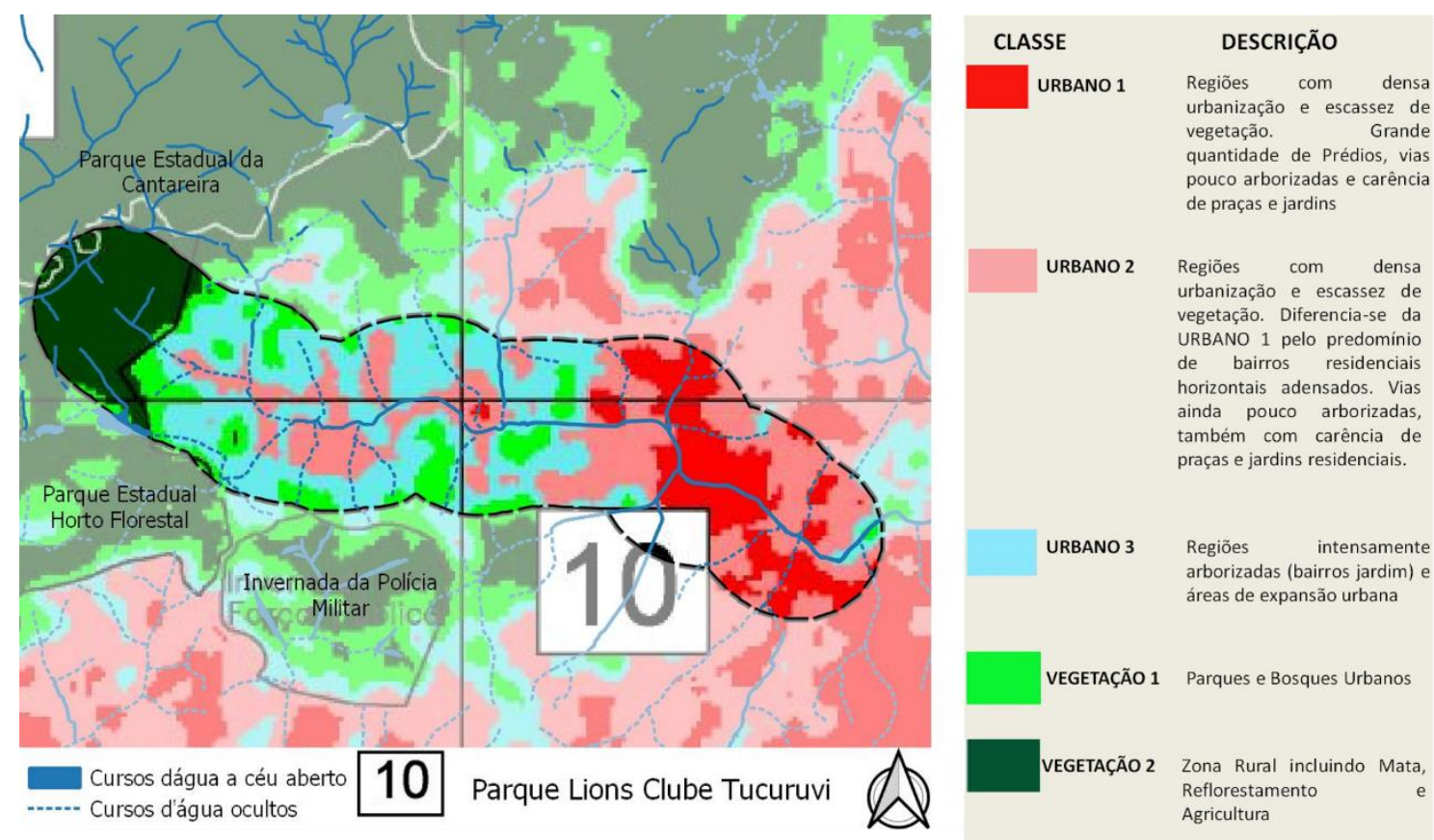

Figura 53- Mapa da distribuição da vegetação do Atlas Ambiental do Município de São Paulo em com destaque para a buffer zone correspondente à área de estudo. Fonte: Trabalho da autora sobre imagem do Atlas Ambiental.

O mapa que foi gerado baseado nas informações do documento "A Vegetação Significativa do Município de São Paulo" (SVMA, 1988), na figura 54, ilustra que área de estudo abrange fragmentos pertencentes à mosaicos verdes bastante relevantes. Esses fragmentos pertencem ao Parque Estadual da Cantareira, classificado como "reserva e área de proteção" (R), e ao Horto Florestal ou Parque Alberto Loefgren, reconhecido como "Parque Estadual" (P). As outras porções de vegetação mais significativas compõem os "bairros- jardins" (BJ). Outros fragmentos verdes menores se fazem presentes, os quais compreendem "glebas não ocupadas em áreas urbanizadas" (Gl), "chácaras remanescentes em áreas urbanizadas" (Chr), "agrupamento de espaços arborizados" (Ag), "jardins de residências" (J), "praças e espaços públicos" (pr), "cemitérios" (cm), "vias arborizadas" (V) e "exemplares isolados" (E). 


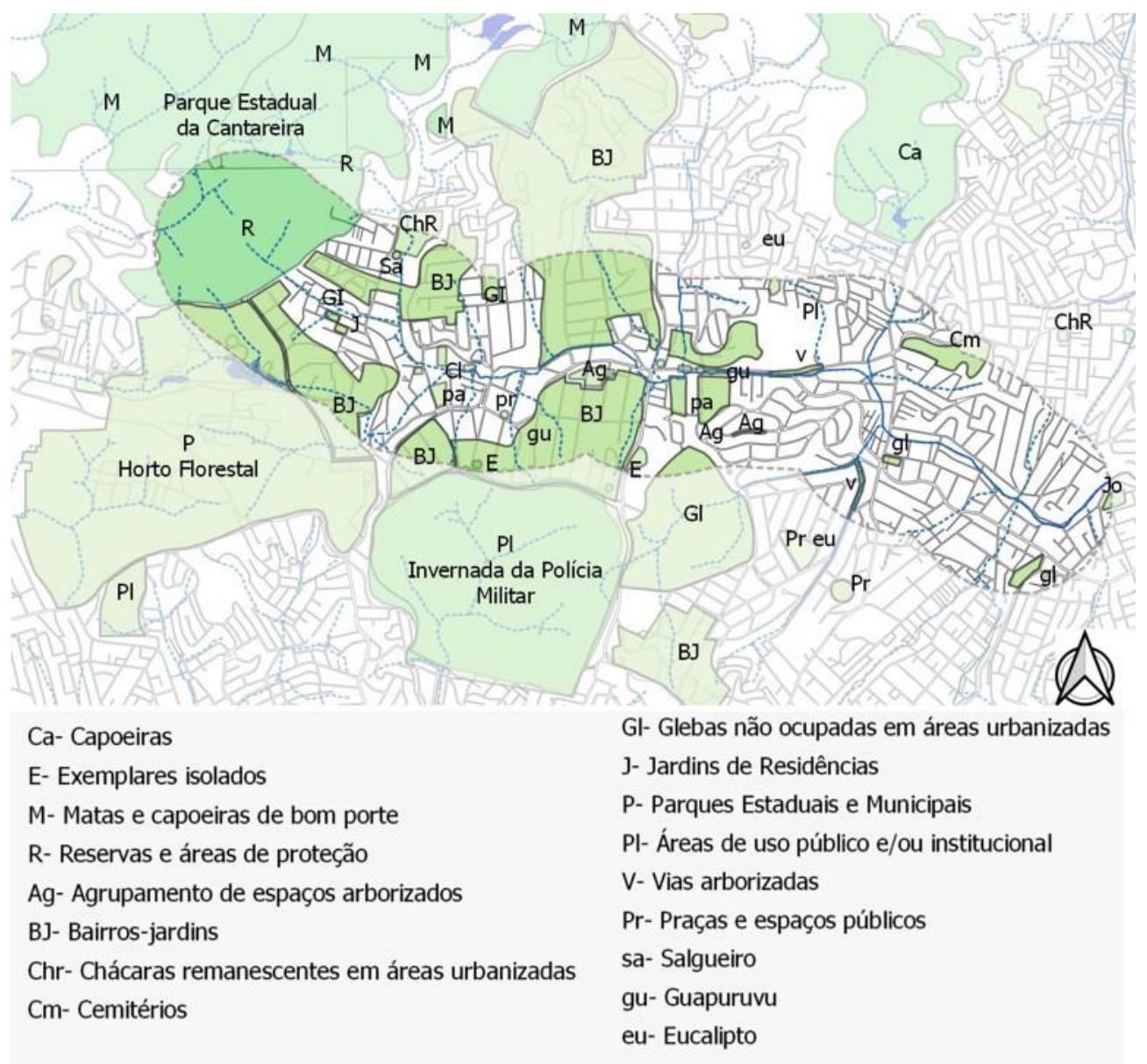

Figura 54- Mapa da vegetação significativa do município de Município de São Paulo com destaque para a buffer zone correspondente à área de estudo. Fonte: Trabalho da autora sobre imagem da Vegetação Significativa de São Paulo (1988).

Ao comparar a publicação da Vegetação Significativa de 1988 e o levantamento das áreas verdes baseado da foto aérea de 2019 do google earth, nota-se a presença de novas áreas vegetadas a exemplo de praças, jardins residenciais, conjuntos habitacionais e outros espaços arborizados. Nota-se também verdes significativos no entorno próximo da buffer zone, espaços estes que se referem às áreas da Invernada da Polícia Militar, Bairro Jardim Ibiratiba, Conjunto Moradas Cantareira, Parque Lions Clube Tucuruvi, Centro Campestre da Cantareira, Horto Florestal e Parque Estadual da Cantareira, sendo esta última a mancha verde mais expressiva. 


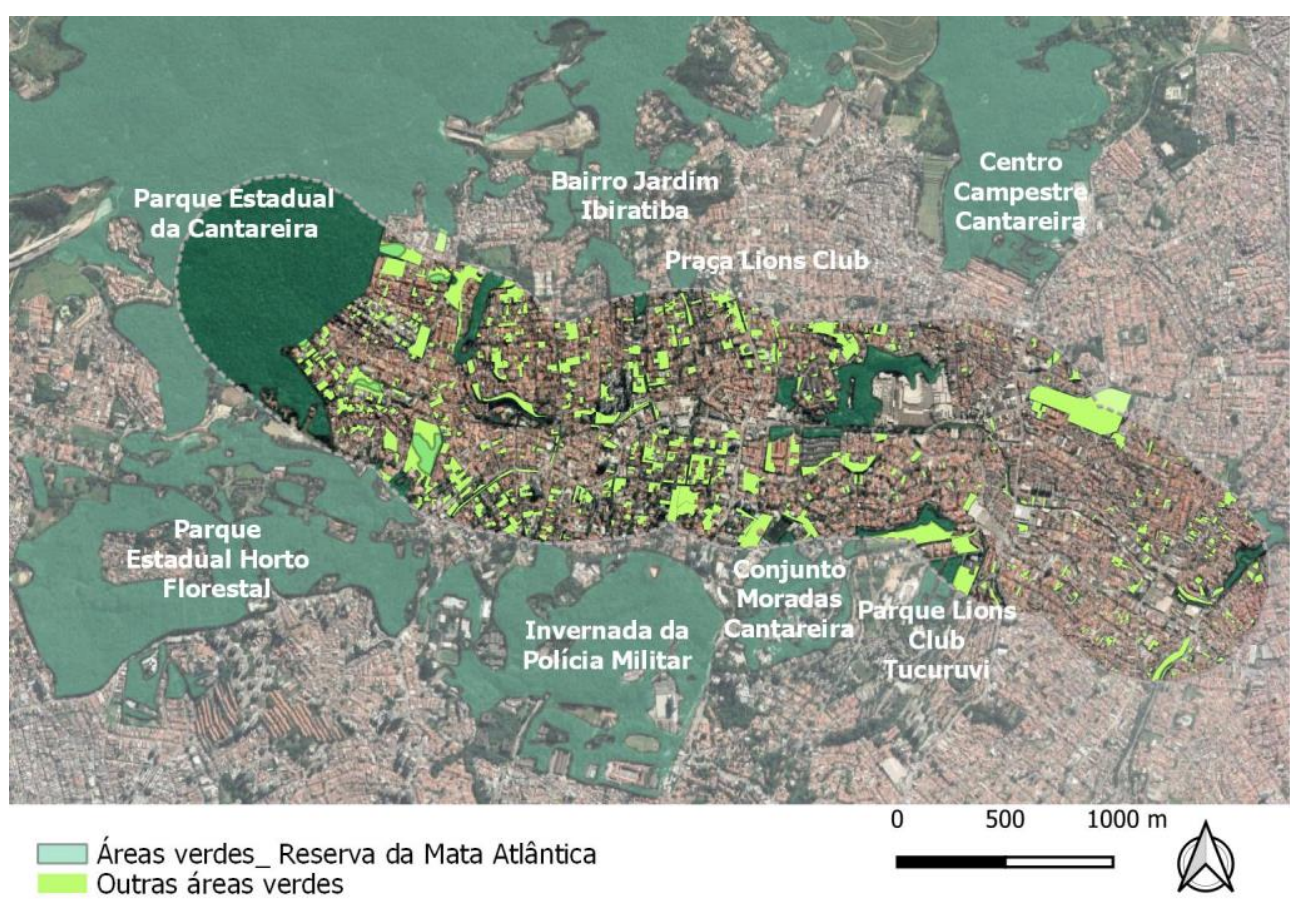

Figura 55- Levantamento da vegetação significativa com base em imagens de satélite do Google Earth no ano de 2019. Fonte: Google Earth (2019)

Considerada uma Unidade de Proteção ${ }^{14}$ que compreende remanescentes da Mata Atlântica, o Parque Estadual da Cantareira possui 7916,52 hectares o que lhe confere o título de uma das maiores áreas de reserva florestal do mundo situada em perímetro urbano. Ao abrigar aproximadamente 678 espécies de plantas e densa vegetação arbórea, o parque oferece uma série de serviços ambientais que contribuem para o bem-estar de um amplo contingente populacional (Governo do Estado de São Paulo, 2009).

\footnotetext{
14 "São espaços territoriais e seus recursos ambientais, incluindo águas superficiais e subterrâneas, com características naturais relevantes e objetivos de conservação com limites definidos, sob regime especial de administração ao qual se aplicam garantias adequadas de proteção" (Governo do Estado de São Paulo, 2009).
} 


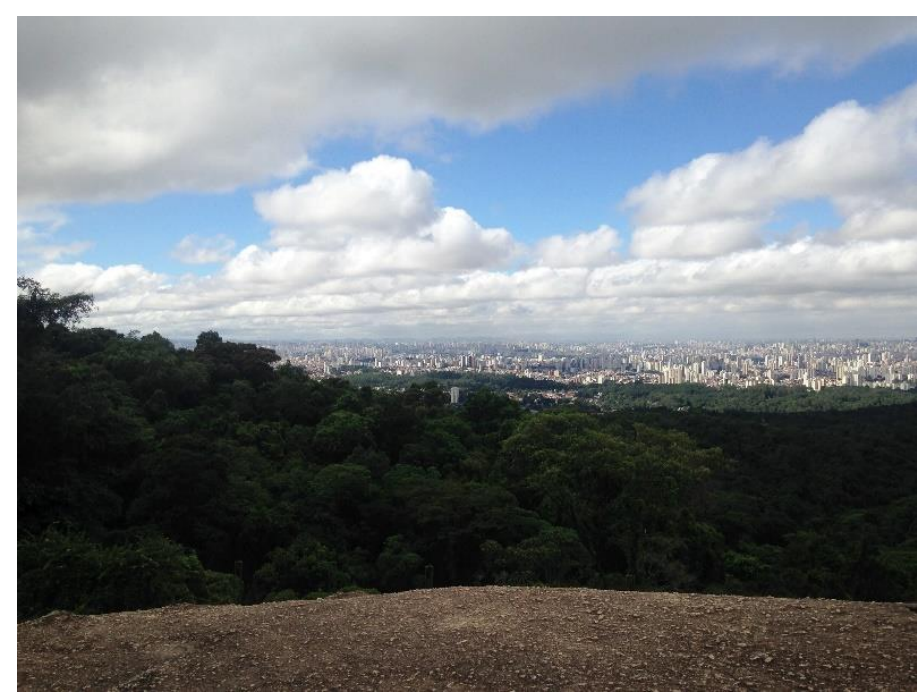

Figura 56- Parque Estadual da Cantareira a partir do Núcleo Pedra Grande. Fonte: LEITE, 2017.

Os serviços ambientais ofertados somados à amplitude da região atribuem à esta unidade de conservação o título de matriz, de acordo com os estudos da Ecologia da Paisagem desenvolvidos por Forman e Godron (1986), citados anteriormente. O Parque Estadual Horto Florestal (ou Alberto Löfgren), que apresenta uma área total de 187 hectares, abriga também remanescentes da Mata Atlântica e cobertura vegetal significativa oferecendo assim benefícios ambientais, recreativos e de lazer para a cidade de São Paulo.

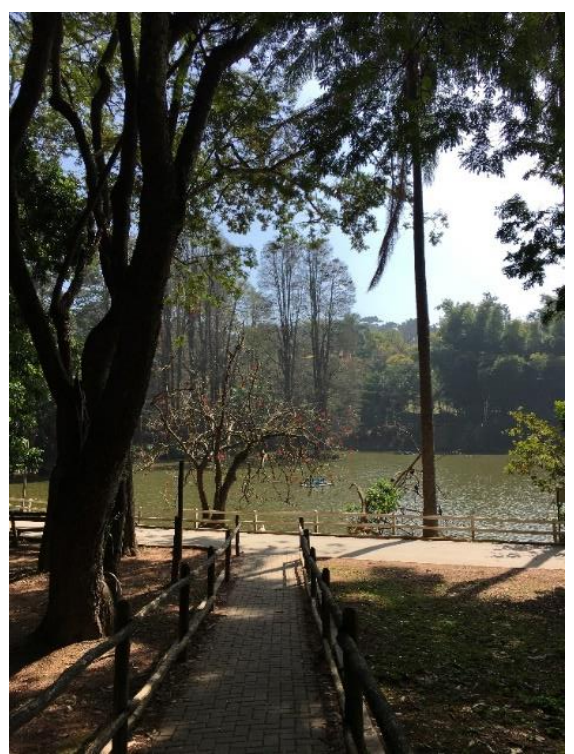

Figura 57- Parque Horto Florestal. Fonte: Produção da autora (2019).

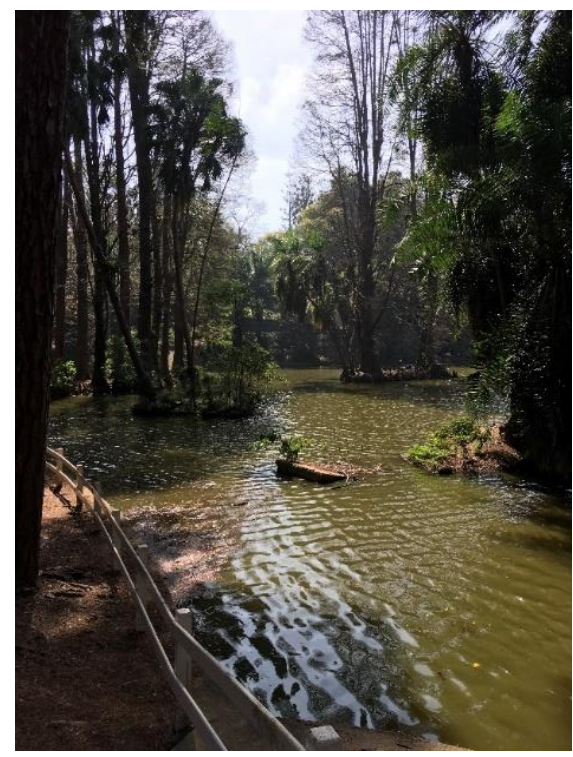

Figura 58- Parque Horto Florestal. Fonte: Produção da autora (2019) 
Além disso, a sua proximidade com o grande núcleo da matriz ecológica da Cantareira o certifica também como um importante núcleo ecológico do município.

Levando em consideração a conectividade de manchas verdes, princípio tido como um dos mais importantes da formação de uma rede de infraestrutura verde, ressalta-se a importância de ligar tais relevantes núcleos às demais manchas verdes, identificadas na área de estudo. Esse tipo de ligação poderia ser efetivada por meio de novas manchas verdes associadas à corredores, estes últimos tidos como percursos lineares formados por vegetação, o que conformaria uma grande matriz verde abrangendo os distritos vizinhos Mandaqui e Tucuruvi.

\subsubsection{NASCENTES E CURSOS D’ÁGUA}

A buffer zone em análise assume como eixo o Rio Tremembé, curso hídrico principal da Bacia Hidrográfica do Tremembé/ Ribeirão Piqueri. Esta bacia apresenta uma área de drenagem de aproximadamente de $35.000 .000 \mathrm{~m}^{2}$ ou $35 \mathrm{~km}^{2}$ de extensão e encontra-se, na sua maior parte, impermeabilizada. Os seus cursos d'água foram nitidamente afetados em decorrência do avanço da urbanização resultando no aterramento e tamponamento de muitos que já não são facilmente reconhecidos ou visualizados. No entanto, e, apesar destas intervenções, ainda é possível identificar a nítida presença de alguns veios hídricos na região no que se refere ao Rio Tremembé e alguns de seus afluentes. Ainda que o estado atual desses corpos hídricos revele a necessidade de um tratamento adequado de suas águas e margens, estes elementos até então assumem relevante importância no que tange à rede hídrica da bacia.

De acordo com o levantamento do Sara Brasil (1930) disponível no Geo Sampa, a nascente do Rio Tremembé se estabelecia nas proximidades da área de reserva da Mata Atlântica pertencente ao Parque Estadual da Cantareira. Essa localidade se encontra urbanizada e pertence à Rua João Miguel Ferreira, 
conforme mostram as figuras 59 e 60. No início do seu curso, o Rio Tremembé recebe a contribuição dos córregos Cantareira e Horto, após seguir predominantemente na direção leste-oeste em paralelo à Rua Amália Lopes de Azevedo. Na área de análise, a extensão linear do rio se apresenta canalizada com calha em concreto ou em terra e águas sujas com necessidade de tratamento.

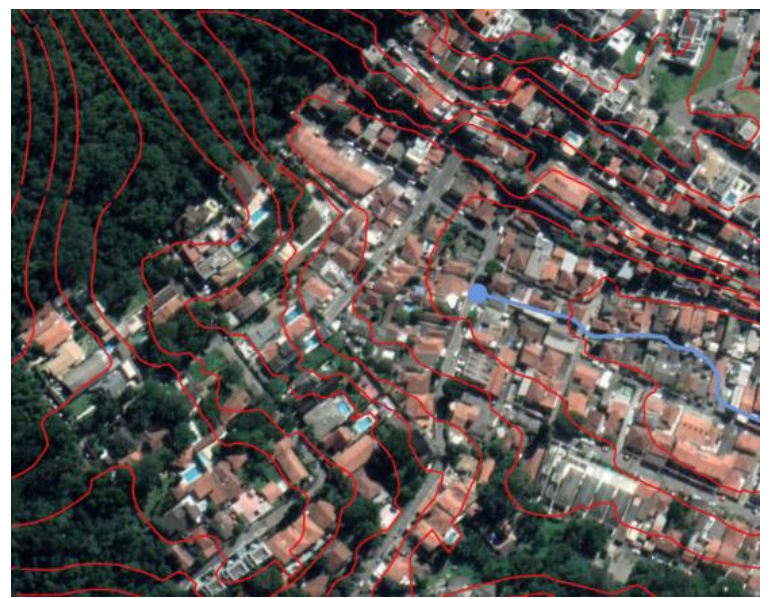

Figura 59- Possível localização da nascente na Rua João Miguel Ferreira. Fonte: Trabalho da autora sobre imagem Geosampa, 2019.

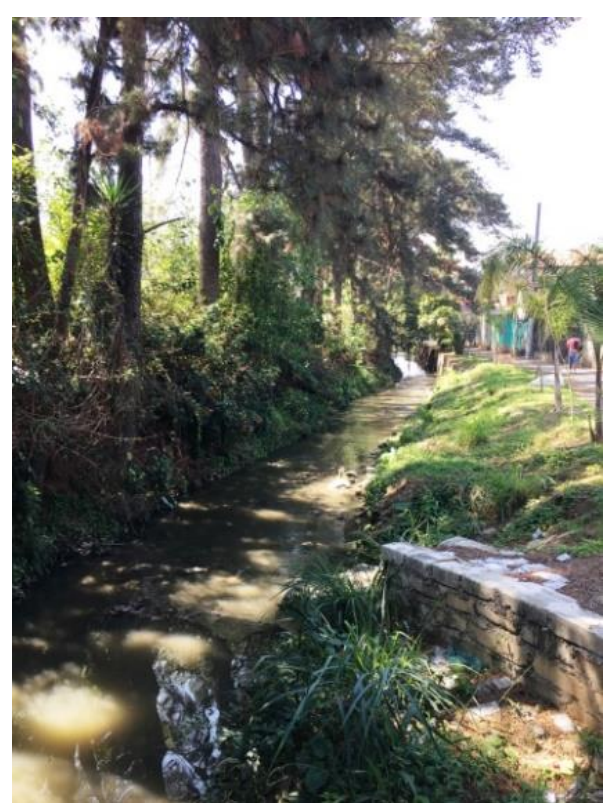

Figura 61- $O$ curso do Tremembé paralelo à Rua Travessa Francisco Iturri aparece com calha em terra e poluição nas águas. Fonte: Produção da autora (2019).

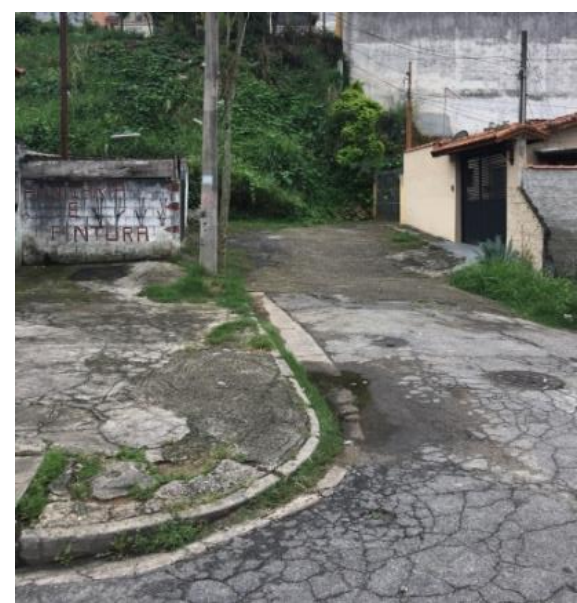

Figura 60- Visão da Rua João Miguel Ferreira na possível localização da nascente. Fonte: Produção da autora, 2018.

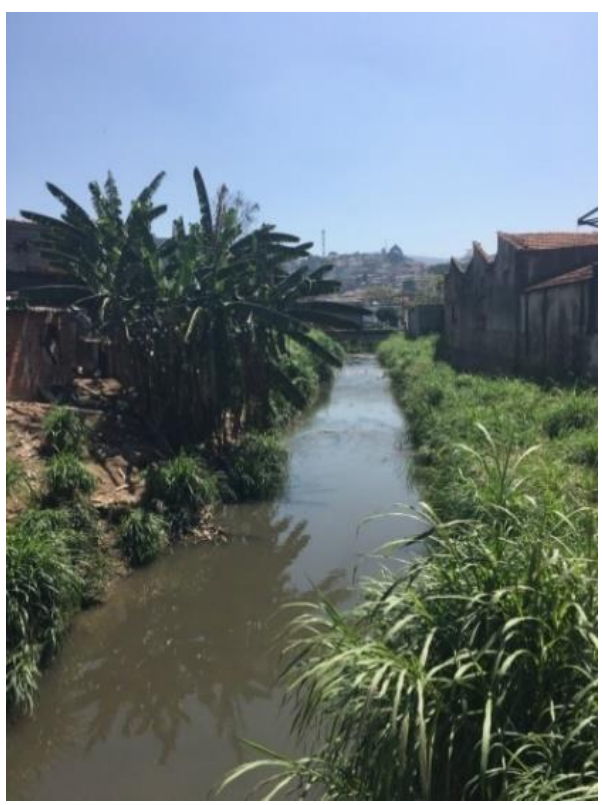

Figura 62- Vista a partir da Rua José Bergamini: a proximidade entre 0 curso do Rio Tremembé e edificações. Fonte: Produção da autora (2019). 


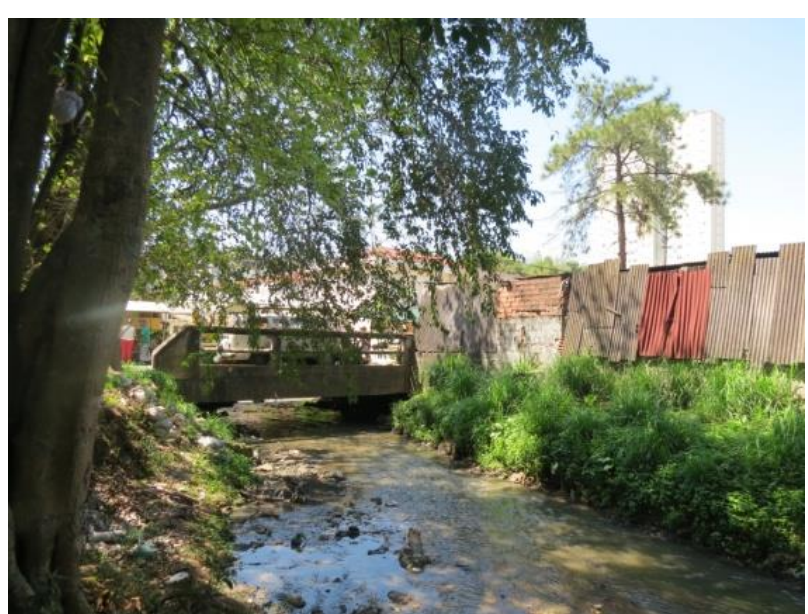

Figura 63- Rio Tremembé com lixo em suas margens a partir da Rua Professor Pedro Pedreschi. Fonte: Produção da autora (2019).

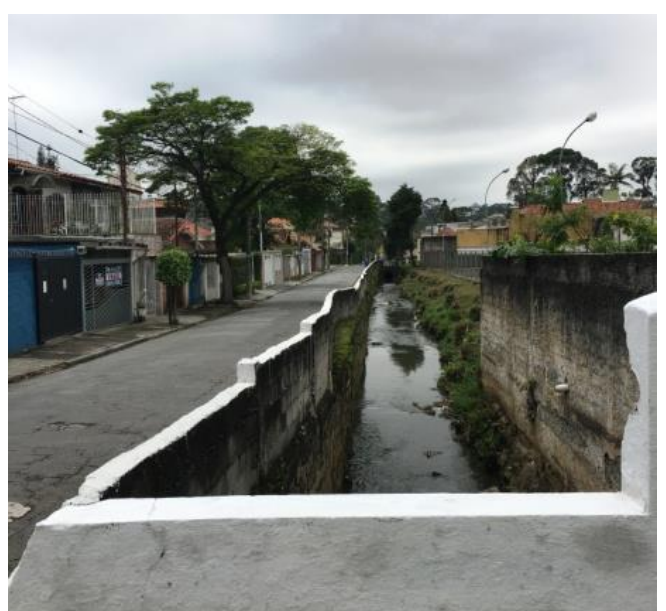

Figura 64- Rio Tremembé com margens concretadas a partir da Rua Raul de Morais Vítor Fonte: Produção da autora (2019).

Antes do processo de urbanização e obras de impermeabilização da área, o Rio Tremembé contava com muitos afluentes. Considerando o interior pertencente à buffer zone de estudo, alguns destes podem ainda ser visualizados, como o Córrego Esmaga Sapo, Córrego IPESP, Córrego Cantareira e outro pequeno corpo hídrico sem denominação. Entretanto, esses mesmos córregos se encontram reprimidos entre construções ilegalmente construídas nas suas margens de proteção e como consequência dessa grande proximidade, muitas vezes recebem diretamente o descarte de esgoto destas.

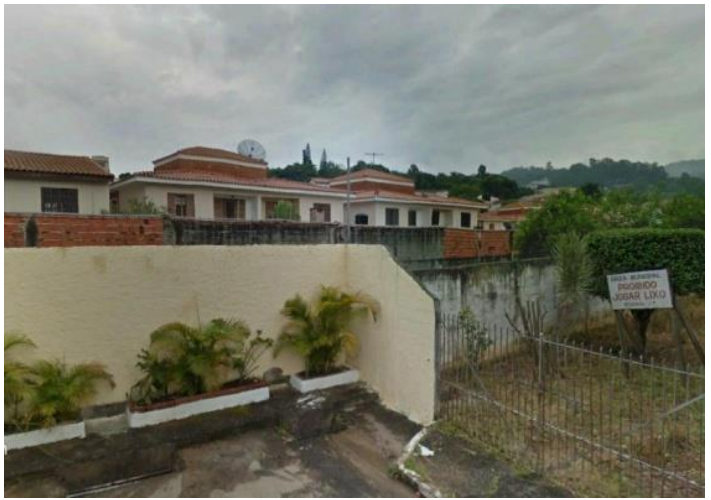

Figura 65- Vista a partir da Rua João Nicolau Chamma: córrego Esmaga Sapo encontra-se confinado entre os muros. Fonte: Google Street View (2019).

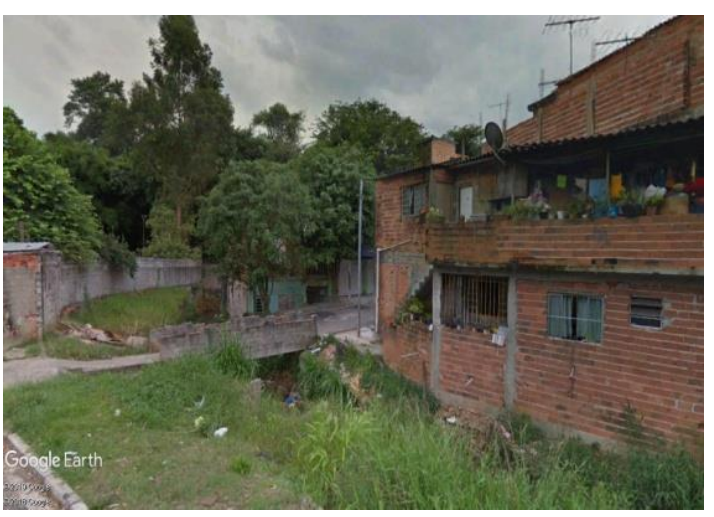

Figura 66- Vista a partir da Rua Arcanjo Cassiel: córrego Cantareira próximo a ocupações irregulares com presença de resíduos sólidos. Fonte: Google Street View (2019). 


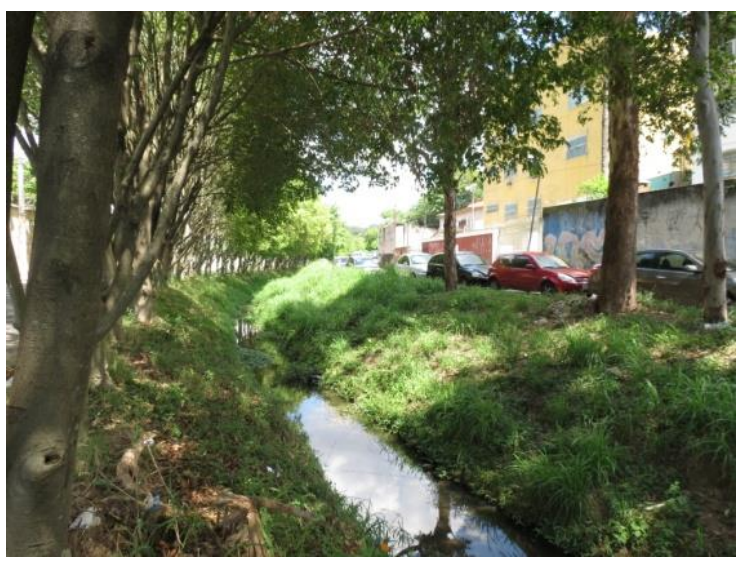

Figura 67- Imagem Córrego IPESP a partir da Av. Vereador Ângelo Bôrtolo. Fonte: Produção da autora (2019).

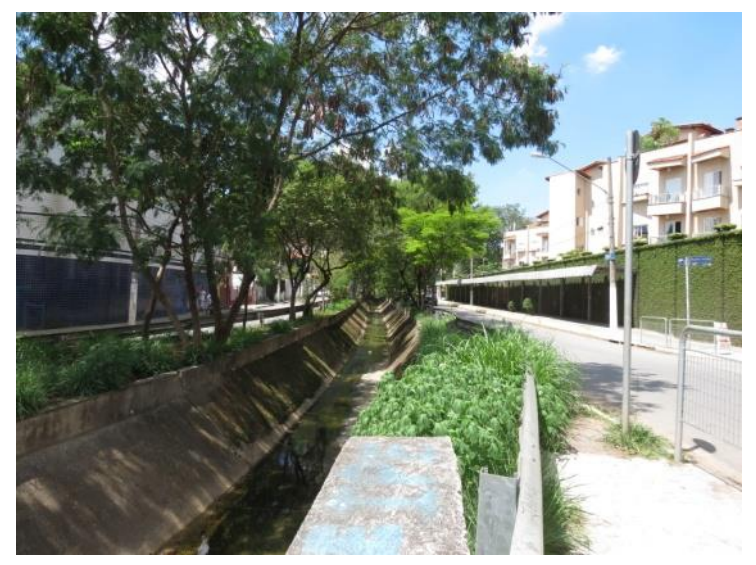

Figura 68- Imagem de um córrego sem denominação (contribuinte do Rio Tremembé) com calha em concreto. Vista a partir da Av. Profa. Vigília Rodrigues Alves. Fonte: Produção da autora (2019).

\subsubsection{GEOMORFOLOGIA E COMPARTIMENTAÇÃO DA PAISAGEM}

A compartimentação topográfica de uma determinada paisagem pode ser definida como a atribuição de classificação à domínios morfológicos com formas de relevo e topografia semelhantes (AB'SÁBER, 1969). Tais características similares são originadas a partir de diversos processos modeladores que configuram a paisagem e lhe concedem um caráter dinâmico, em constante processo de reelaboração (SCHUTZER, 2012).

Nessa direção, Schutzer afirma que para identificar a compartimentação topográfica de uma determinada área é necessário conhecer as formas de relevo predominantes que caracterizam a compartimentação das paisagens, e cita como exemplo algumas mais comuns: planaltos, colinas, morros, terraços de diferentes tipos, escarpas e várzeas etc. O autor acrescenta a importância de compreender estas unidades enquanto frutos dos processos naturais de funcionamento da natureza e que, portanto, espelham as dinâmicas ecossistêmicas que orientam a formação de cada espaço.

De acordo com a análise da topografia e mapa hipsométrico foi possível identificar 05 (cinco) tipos de compartimentos de relevo na área de estudo, são 
eles: anfiteatros e nascentes; planícies aluviais; encostas, vertentes das colinas e outeiros; outeiros, colinas e pequenos espigões secundários; montanhas e serras.

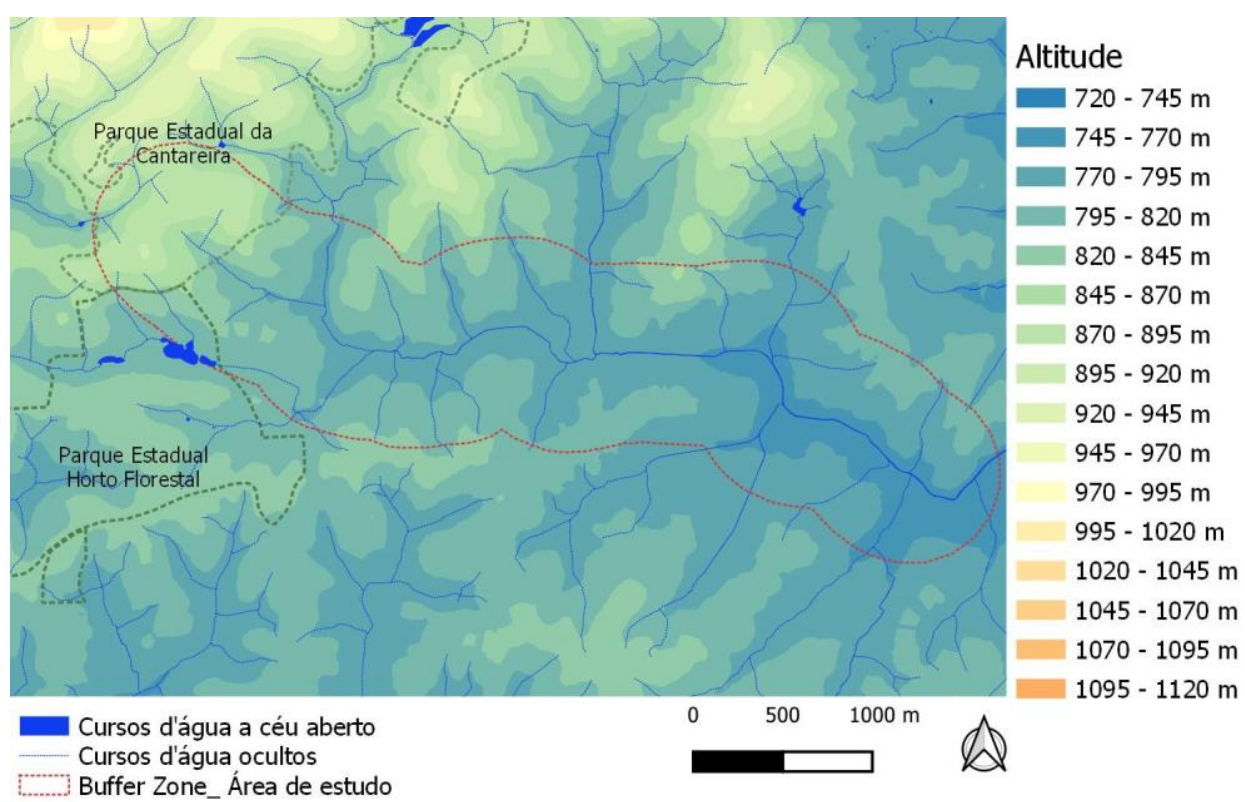

Figura 69- Mapa hipsométrico mostrando as altitudes da região em metros onde a linha tracejada vermelha corresponde à área de estudo. Fonte: Trabalho da autora sobre imagem Geosampa.

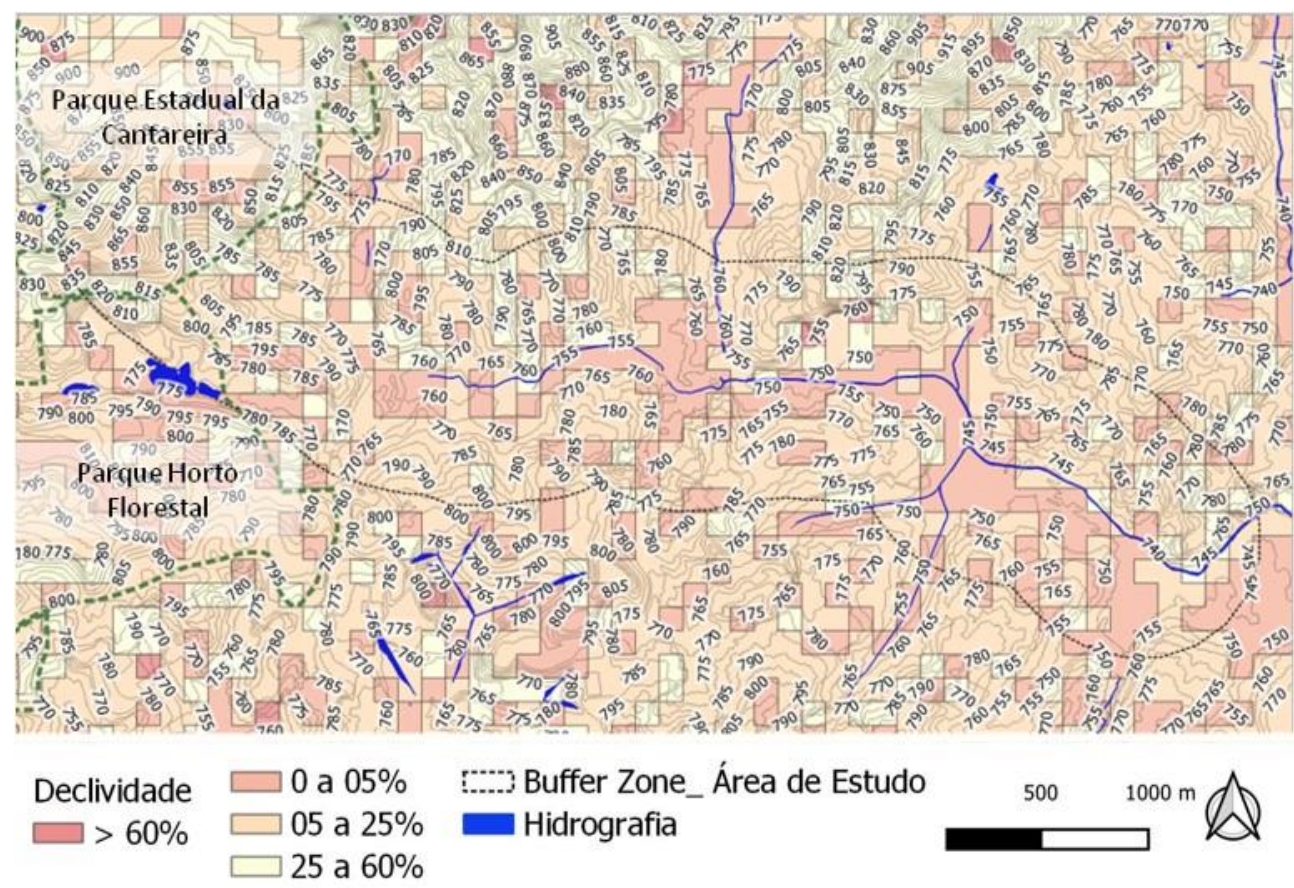

Figura 70- Mapa da topografia mostrando as declividades da região em porcentagem. Fonte: Trabalho da autora sobre imagem Geosampa. 
Tido como eixo da buffer zone delimitada, o curso do Rio Tremembé se estabelece por volta da cota de 750 chegando até a cota de 745 na porção que se direciona para o Rio Cabuçu de Baixo, este já localizado no extremo leste da Bacia do Tremembé.

O entorno dos corpos d'água, afluentes do Rio Tremembé, pertencem ao compartimento dos anfiteatros e das nascentes, sendo aqueles localizados na porção norte estão vinculados principalmente às grandes declividades da Serra da Cantareira. Os demais anfiteatros de drenagem da área de estudo, muitos já suprimidos pela urbanização, se originaram a partir dos pequenos espigões secundários. Schutzer define essas áreas como "espaços da natureza por excelência" em que o processo de escoamento é predominante, sendo necessário a preservação da umidade natural com permeabilidade adequada no topo do espigão e densa vegetação nos anfiteatros.

O compartimento da planície aluvial é caracterizado como áreas baixas e aplainadas e no enfoque de estudo se estabelecem entre as cotas de 745 a 770 . De acordo com Schutzer (2012), essas áreas, que também podem ser chamadas de várzeas, recebem as águas e sedimentos das áreas mais altas da bacia além de apresentarem solo úmido e lençol freático superficial.

O relevo ao redor da planície aluvial do Rio Tremembé é formado por encostas, vertentes das colinas e outeiros. Apresentam altitudes que variam de 770 na parte mais baixa da planície aluvial chegando a 795 metros em alguns topos. A declividade nesse compartimento varia de 5 a $25 \%$ em alguns trechos podendo chegar até $60 \%$ em outros mais íngremes. Essas áreas se encontram densamente ocupadas e o tipo declividade acentua o processo de escoamento superficial podendo causar erosão e deslizamentos quando carentes de vegetação ou quando não possuem uma drenagem eficiente (SCHUTZER, 2012).

Foi identificado também o compartimento de relevo outeiros, colinas e pequenos espigões secundários com início na altitude de 795m com alcance até a cota de $815 \mathrm{~m}$. Essas áreas estão vinculadas à serra da Cantareira ao norte e à divisa da bacia do Tremembé com a bacia do Mandaqui, ao sul. 
Na porção referente à Serra da Cantareira, foi observado o compartimento de relevo montanhoso e serras. Marcado por altas altitudes, esse tipo de compartimento tem início na cota de $815 \mathrm{~m}$ e chega a $1120 \mathrm{~m}$ nos topos mais altos com declividades que variam de 5 a $25 \%$ e chegam até $60 \%$ em alguns trechos. Schutzer (2012) afirma que nas faixas com essas características apenas trechos mais restritos podem ser ocupados, devido à elevada instabilidade das encostas. O escoamento superficial e a erosão do solo também são processos dominantes, em especial nas regiões serranas com ausência de cobertura vegetal. O geógrafo acrescenta ainda que os compartimentos serranos são tidos como um ambiente extremamente frágil sob o ponto de vista natural e ambiental com grande relevância pois "são áreas naturalmente produtoras de água de ótima qualidade, sendo esse o principal serviço ambiental desempenhado para a sociedade" (SCHUTZER, 2012).

\subsubsection{ESTRUTURA SUPERFICIAL DA PAISAGEM}

De acordo com Ross (2000), a estrutura superficial da paisagem se refere aos aspetos da porção epidérmica da crosta terrestre os quais são frutos dos processos geomorfológicos em atuação constante. O geógrafo Schutzer afirma que, no que tange ao tipo de solo e suas características, suas condições também são influenciadas pelos processos antrópicos e, por isso, o depósito deve ser analisado tanto do ponto de vista físico quanto sob a perspectiva do seu comportamento frente aos processos naturais e humanos. A partir disso, o tipo de solo pode apontar diferentes potencialidades pautadas em: suporte para ocupação em áreas urbanas (construções de loteamentos e vias públicas, pólos industriais, rodovias etc) recurso para utilização (abastecimento de água, uso agrícola e energético, por exemplo) ou como um ambiente sujeito à preservação (onde existem processos naturais importantes e que atuam como suporte de ambientes).

Sabe-se que os aspectos da estrutura superficial da paisagem se relacionam diretamente com os processos naturais, ao passo que os solos se diversificam de 
acordo com seu potencial de armazenamento, infiltração ou escoamento das águas pluviais. Em face disto, as investigações no que se refere à estrutura superficial da paisagem nas grandes áreas urbanas apontam para aspectos de estabilidade e suporte sujeitas às dinâmicas da natureza vigentes além de que devem também incluir as interferências já produzidas por essas ações antrópicas. Entre essas interferências estão: obras de retificação, cortes e aterros para obras de estradas e ferrovias, loteamento de moradias, aterramento dos canais de drenagem, entre outras. Por meio dessas remodelagens da paisagem, o homem também modificou a característica desses depósitos superficiais, que, em muitos casos, já não apresenta sua composição natural (SCHUTZER, 2012).

Segundo o mapa geológico do município de São Paulo disponível no Atlas Ambiental do município, área de estudo assume dois tipos de formações geológicas. O rio Tremembé e seus afluentes, indicados na figura 71 apresentam na região de seus vales cobertura aluvial e coluvial quaternária constituídos pelos solos areais, argilas e conglomerados com espessura métrica. Nas demais áreas o solo é formado pelas unidades magmáticas e metamórficas e sua composição é principalmente granítica conforme mostra a seção geomorfológica desenvolvida por Aziz Ab'Saber (2007) presente na figura 72. 


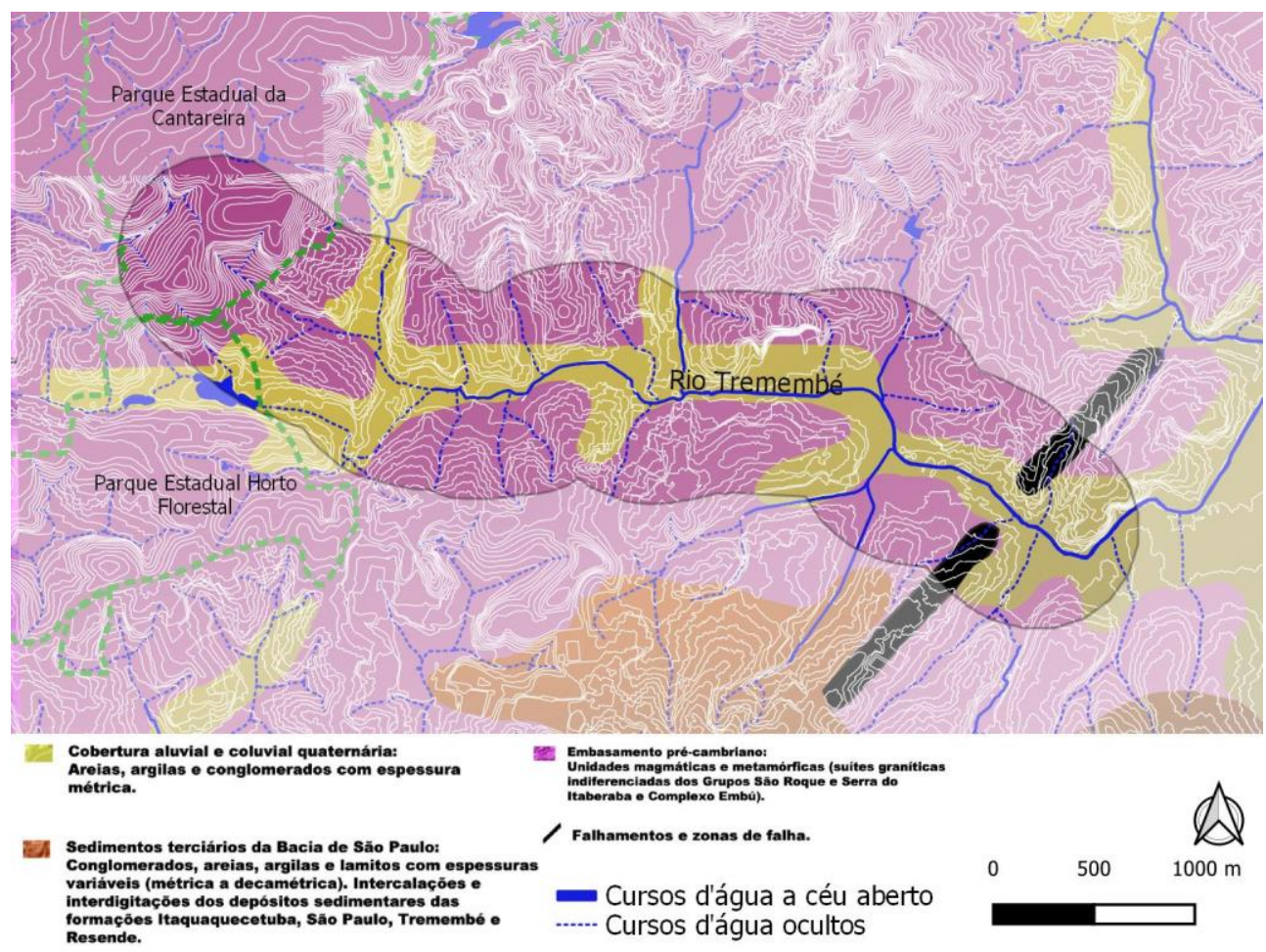

Figura 71- Mapa geológico simplificado do Atlas Ambiental do Município de São Paulo com destaque para a área de estudo. Fonte: Trabalho da autora sobre imagem do Atlas Ambiental.

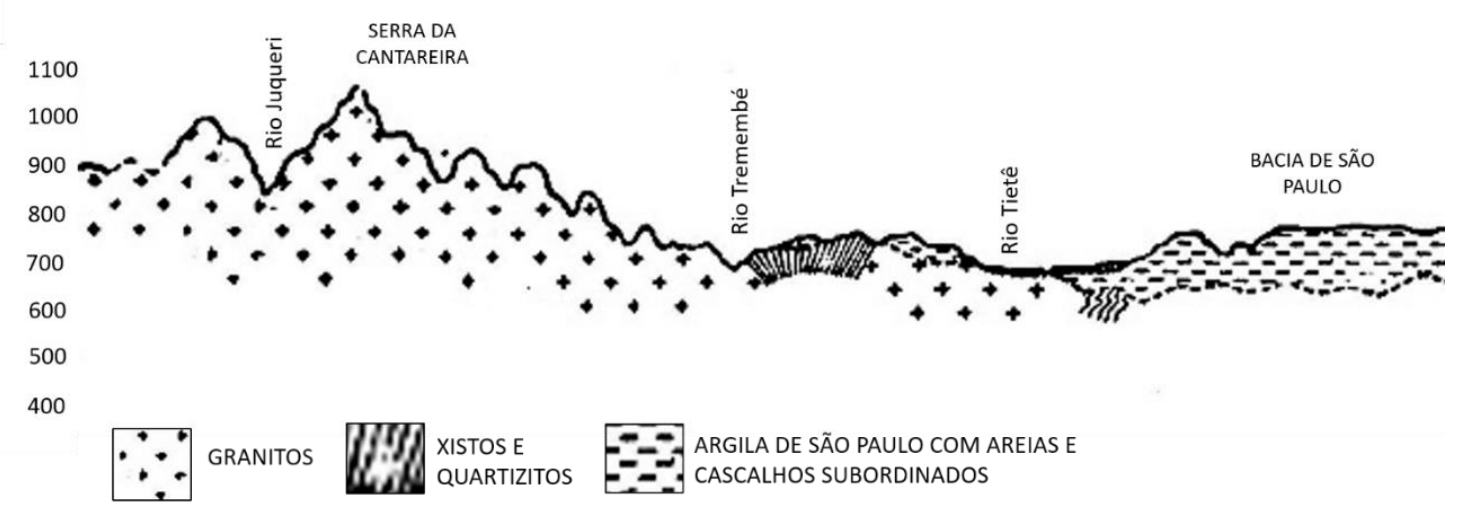

Figura 72 Seção Geológica da Serra da Cantareira que ilustra sua composição do solo. Fonte: Ab'Saber (1952) com adaptações da autora.

O esquema geológico feito por Ab'Sáber na Região do Horto e Tremembé (figura 73) evidencia também a presença de argilas, areias e cascalhos ao longo do vale do Rio Tremembé e nas demais áreas próximas a presença de granitos. 


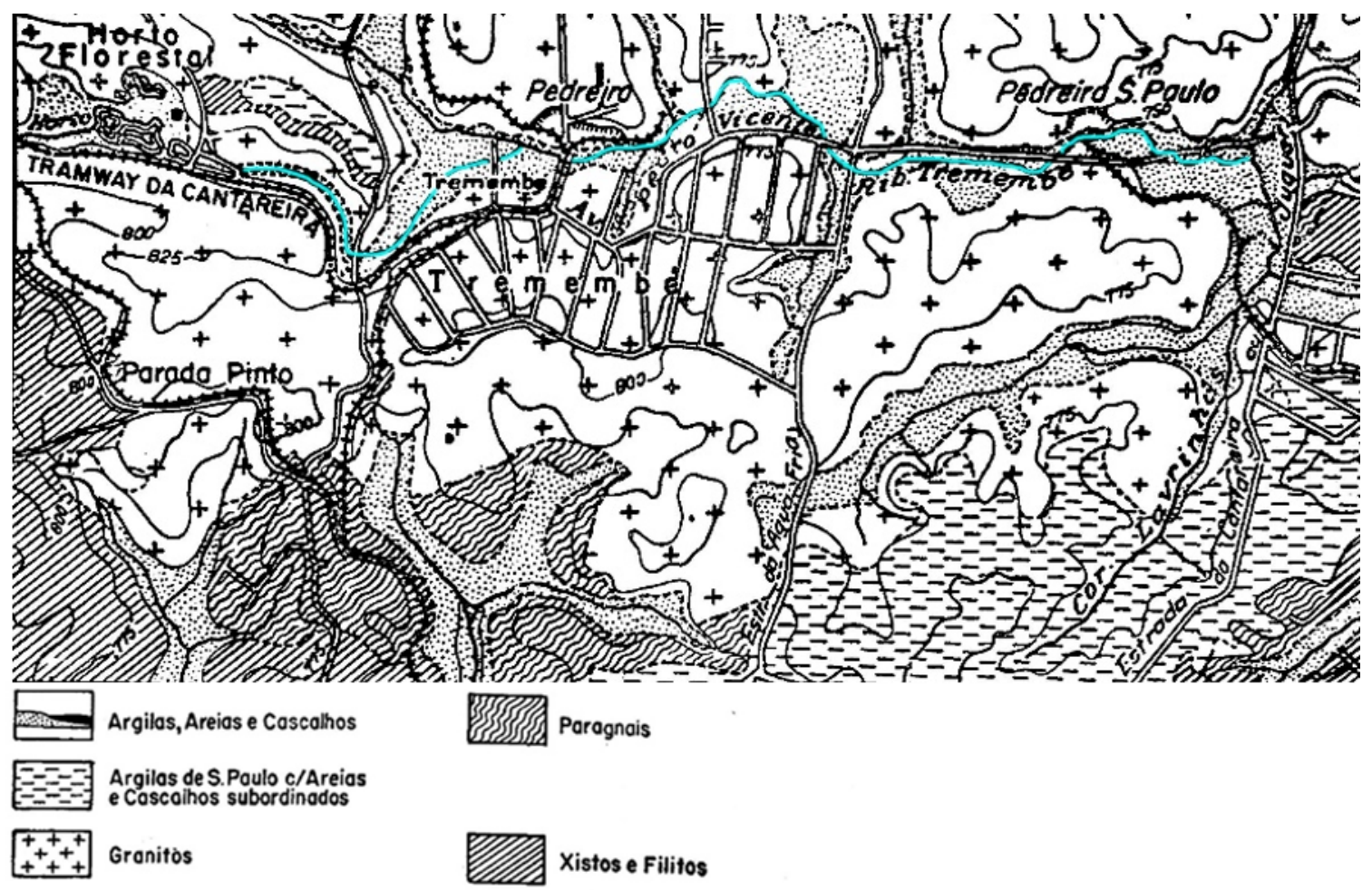

Figura 73- Esboço Geológico da Região do Horto Florestal e Tremembé onde a linha azul representa o curso do Rio Tremembé. Fonte: Ab'Saber (1952) com adaptações da autora (2019).

As planícies aluviais, tipo de compartimento presente no canal do Rio Tremembé e de seus afluentes, são áreas baixas e planas receptoras de água e sedimentos advindos dos outros compartimentos. Seus solos caracterizam-se pela umidade visto que o lençol freático se situa entre um e três metros abaixo da superfície. Em virtude desta proximidade, ainda que nesse tipo de compartimento predomine o processo de infiltração das águas pluviais, a capacidade de infiltração do solo torna-se restrita e o excesso de água origina lagos, canais ou braços de rios (SCHUTZER, 2012).

Esse fenômeno é confirmado na imagem histórica do Mapa Sara Brasil da década de 1930 que ilustra a presença dos cursos d'água e conformação de meandros na região das planícies (Imagem 74). Denominadas também como várzeas, áreas como estas são bastante sensíveis caracterizadas como "espaços da natureza por excelência sobretudo os trechos estreitos, e devem ser ocupadas predominantemente por parques, mantendo-se uma arborização intensa e lagos naturais de retenção de água" (SCHUTZER, 2012, p. 201). A vocação pela atividade 
biológica nesses compartimentos ocorre principalmente devido à presença maciça de água que atua na umidificação do ar além de favorecer o desenvolvimento de vegetação arbórea intensa e matas ciliares, elementos importantes para a manutenção da diversidade biológica e mitigação de assoreamento e erosão dos cursos d'água (SCHUTZER, 2012).

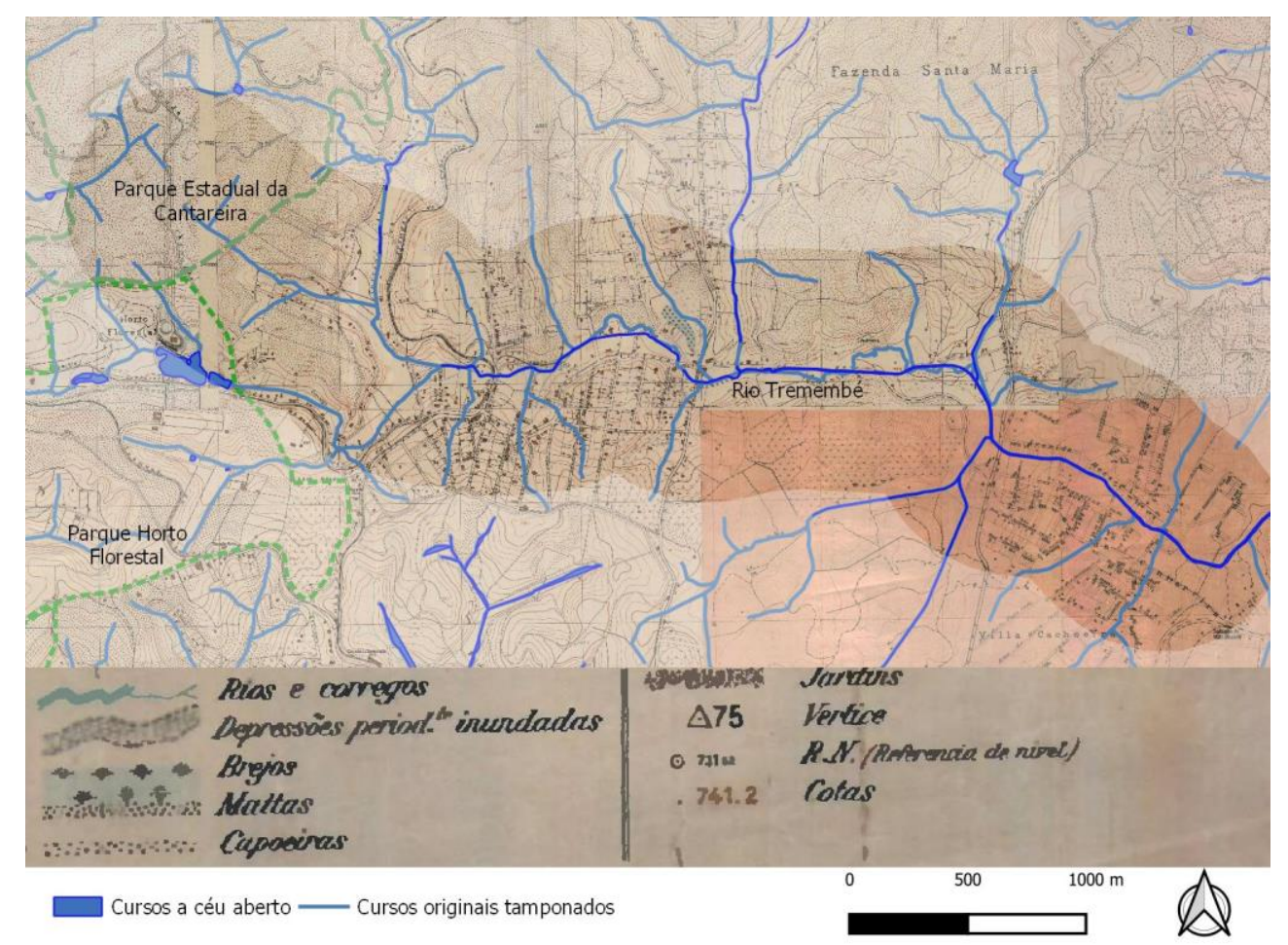

Figura 74- Mapa Sara Brasil de São Paulo com destaque para a área de estudo. As linhas azuis em claro representam os cursos originais tamponados e as linhas azuis escuras representam os córregos que correm a céu aberto. Fonte: Trabalho da autora sobre imagem do Sara Brasil.

Ao longo do tempo a região de enfoque foi tomada pela urbanização, responsável pela alteração da sua dinâmica natural original por meio de desmatamentos, alterações dos meandros originais e obras que culminaram no tamponamento de diversos córregos. Dentre os efeitos negativos dessas intervenções está o agravamento de enchentes na região, que também recebe os sedimentos das cotas mais altas do terreno advindos dos compartimentos pertencentes à Serra da Cantareira. A composição granítica nesta região, por sua vez, possui baixa capacidade de drenagem e solo profundo firme formado pelo 
maciço cristalino da Cantareira (SCHUTZER,2012; AB'SÁBER, 2007). Os problemas relativos à drenagem e responsáveis pelas enchentes tem origem nas encostas de conformação íngremes, o que acentua os processos de escoamento superficial e risco de erosão.

\subsubsection{FISIOLOGIA DA PAISAGEM}

O conceito de fisiologia da paisagem se refere aos mecanismos, tanto naturais quanto aqueles acionados pelo homem, que, juntos, contribuem para o funcionamento e conformação da paisagem. Nesse contexto, identificar aspectos da fisiologia implica em identificar os processos que induzem à evolução da forma de um determinado espaço físico, incluindo os processos naturais e as correntes interferências humanas no ambiente urbano (SCHUTZER, 2012). A fisiologia da paisagem analisa os processos em plena atividade e envolve elementos relacionados à dinâmica climática, hidrodinâmica e outras ações humanas que interferem na formação das paisagens alterando e modificando seus ciclos.

Dentre os inúmeros efeitos empregados à paisagem, a urbanização causa a alteração nas dinâmicas climáticas que hoje contribuem para um cenário global bastante preocupante com um impacto negativo no índice de mortalidade e na saúde da população. A chamada "ilha de calor" consiste em uma das consequências desse tipo de alteração, onde $\mathrm{O}$ ar e as temperaturas das superfícies se encontram mais quentes do que nas áreas rurais circundantes. Incrementos nas áreas urbanas como utilização de materiais de construção que absorvem mais calor do sol, impermeabilização de vias com asfalto e a escassez de vegetação em prol da construção de mais avenidas estão entre algumas ações responsáveis pelo agravamento da crise no cenário ambiental e climático nas cidades (GARTLAND, 2008).

Quanto aos aspectos climáticos urbanos do município de São Paulo, estes também constam no Atlas Ambiental e foram gerados a partir da sobreposição 
de várias camadas de informação como temperatura aparente da superfície, presença ou ausência de cobertura vegetal, uso do solo predominante, entre outros. Tais dados, que associam os efeitos da ação antrópica à cada micro clima, foram então articulados dando origem às chamadas "unidades climáticas urbanas". A área de interesse deste estudo engloba 03 unidades: "Unidade Climática Urbana Periférica da Zona Norte- Parque da Cantareira", "Unidade Climática Urbana Central Além do Tietê Residencial Baixo Tucuruvi" e "Unidade Climática Urbana Central Além do Tietê Residencial Baixo Limão/ Casa Verde".

A primeira unidade representada em verde que abrange o Parque Estadual da Cantareira e o Horto Florestal apresenta uma dominante porcentagem de áreas verdes e topografia mais acentuada apresentando uma situação climática privilegiada que varia entre 23 a $28^{\circ} \mathrm{C}$. A maior parte do recorte de estudo pertence à Unidade Climática Urbana Central Além do Tietê Residencial Baixo Tucuruvi que está em amarelo, composta por uma porcentagem de áreas verdes com variação de média a grande o que reflete também na alteração das temperaturas médias nessas áreas que estão entre de 26 e $31^{\circ} \mathrm{C}$. Uma pequena porção da área de estudo compreende ainda a "Unidade Climática Urbana Central Além do Tietê Residencial Baixo Limão/ Casa Verde" representada no mapa pela cor vermelha. Nessa faixa a porcentagem de áreas verdes é pequena com elevadas temperaturas que variam entre 29 a $32^{\circ} \mathrm{C} .{ }^{15}$

\footnotetext{
${ }^{15}$ As temperaturas médias relatadas tiveram como base a Temperatura de Superfície Estimada pelo Processo da Banda Termal do Satélite LANDSAT $7\left({ }^{\circ} \mathrm{C}\right)$ aferidas no dia 30 de abril de 2000 às $09 \mathrm{~h}$ e $57 \mathrm{~min}$. Estes e outros dados relacionados estão presentes na legenda do mapa "Unidades Climáticas Urbanas" no Atlas Ambiental do Município de São Paulo (2000).
} 


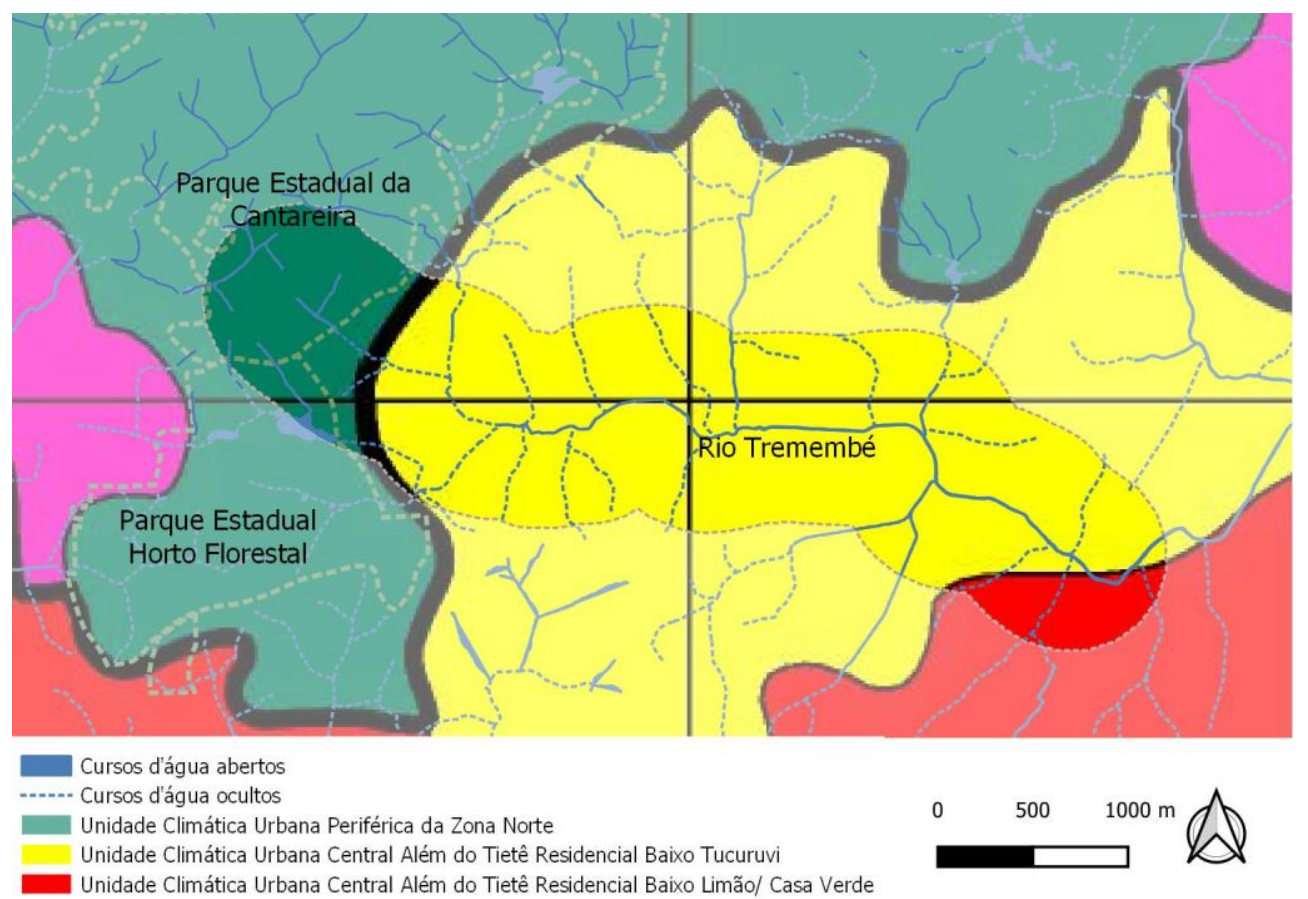

Figura 75- Mapa que mostra as Unidades Climáticas com destaque para a área de estudo. Fonte: Trabalho da autora sobre imagem do Atlas Ambiental.

Ao considerar os números do mapa presente no Atlas Ambiental da Cidade de São Paulo que disponibiliza a temperatura aparente de superfície ${ }^{16}$, a área de estudo apresenta nas áreas de sua extremidade sentido sudoeste tonalidades de cores mais quentes apontando temperaturas que variam de $28,5^{\circ} \mathrm{C}$ a $31^{\circ} \mathrm{C}$. Essas temperaturas de superfície mais elevadas reforçam a influência da ausência de áreas verdes nesta faixa. A paleta de cores vai suavizando a intensidade na medida em que se aproxima das áreas mais vegetadas onde as temperaturas estão entre $28^{\circ} \mathrm{C}$ a $27^{\circ} \mathrm{C}$. Ao adentrar os limites do Parque Estadual da Cantareira as temperaturas caem cerca de $1^{\circ} \mathrm{C}$, devido a presença de densa vegetação arbórea nesta região.

\footnotetext{
${ }^{16}$ Temperatura aparente de superfície registrada no dia 03 de setembro de 1999 às 09h e 57 min. Outros dados estão presentes no mapa "Temperatura aparente de superfície" no Atlas Ambiental do Município de São Paulo (2000).
} 


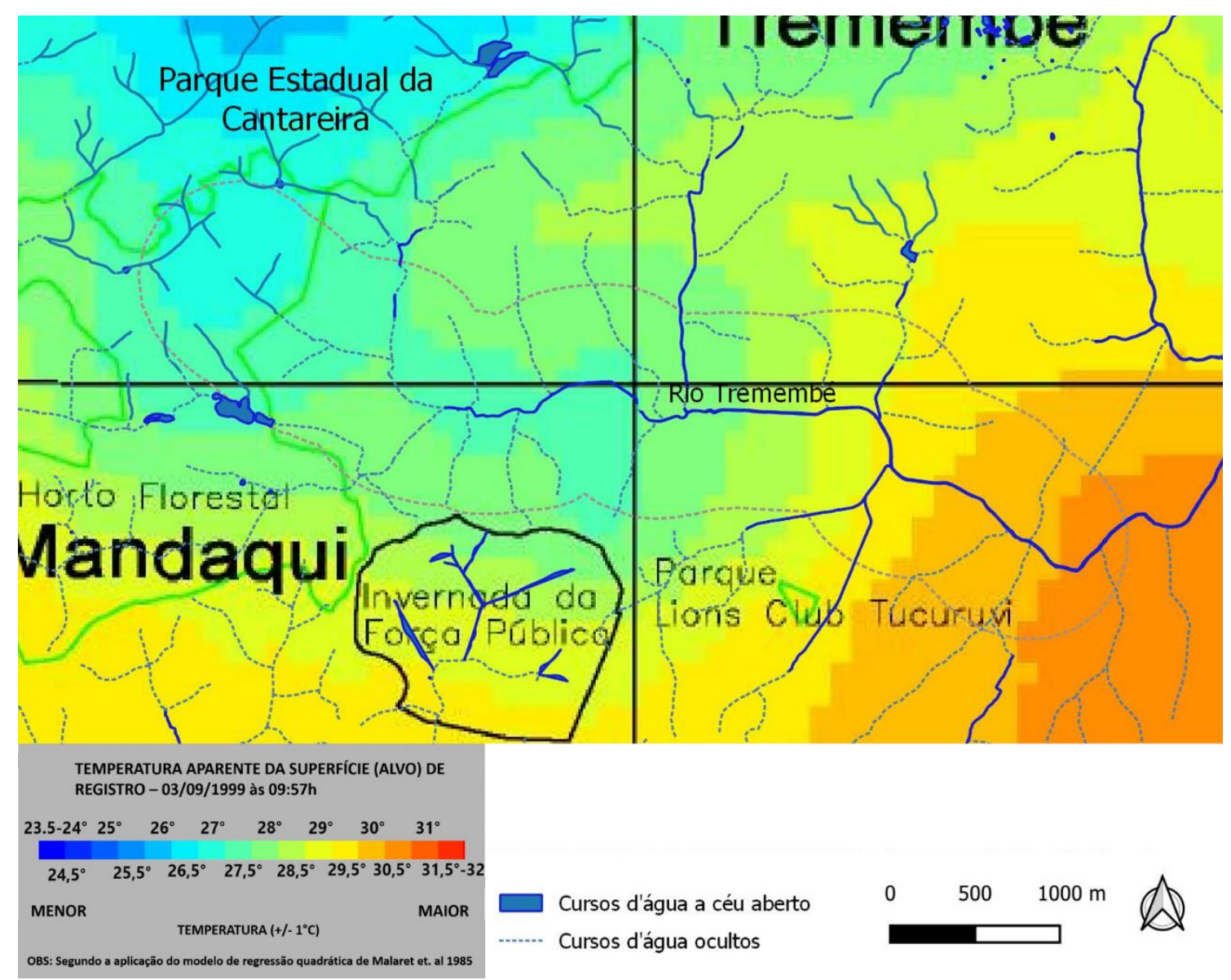

Figura 76- Mapa das ilhas de calor com destaque para a área de estudo. Fonte: Trabalho da autora sobre imagem do Atlas Ambiental.

\subsubsection{ZONEAMENTO AMBIENTAL: POTENCIALIDADES NATURAIS E FUNÇÕES AMBIENTAIS DA ÁREA DE ESTUDO}

Schutzer (2012) define o zoneamento ambiental como uma metodologia de leitura tanto do meio físico quanto do meio urbano e que tem como finalidade principal o reconhecimento daqueles espaços capazes de incentivar processos naturais. Essa leitura visa entender mais a fundo as dinâmicas ambientais atuantes e a capacidade de suporte do organismo urbano com o objetivo de determinar diretrizes de ocupação em concordância tanto com as ações urbanas quanto com as ações ecológicas atuantes. Esse plano de ocupação considera diferentes unidades de aproximação da paisagem incluindo aquelas categorias 
anteriormente citadas que incluem aspectos do compartimento do relevo, estrutura superficial e fisiologia da paisagem.

Nessa direção, o zoneamento ambiental se caracteriza também como um mapeamento geomorfológico, indica as unidades de paisagem resultantes em determinado território, incluindo suas potencialidades e condicionantes. O mapa gerado apresenta a delimitação das áreas suscetíveis aos processos de percolação, infiltração e filtragem, ao armazenamento de água, ao estímulo de evaporação e evapotranspiração bem como redução da emissividade de calor. $O$ mapeamento apresenta como produto também aqueles espaços com restrição ao escoamento superficial, à infiltração, os que não favorecem a filtragem, interrompem os ventos e prejudicam o lençol freático (SCHUTZER, 2012).

A seguir mostra-se o zoneamento ambiental gerado para a área de estudo (figura 77) e em seguida a descrição das funções ambientais de cada compartimento identificado. 


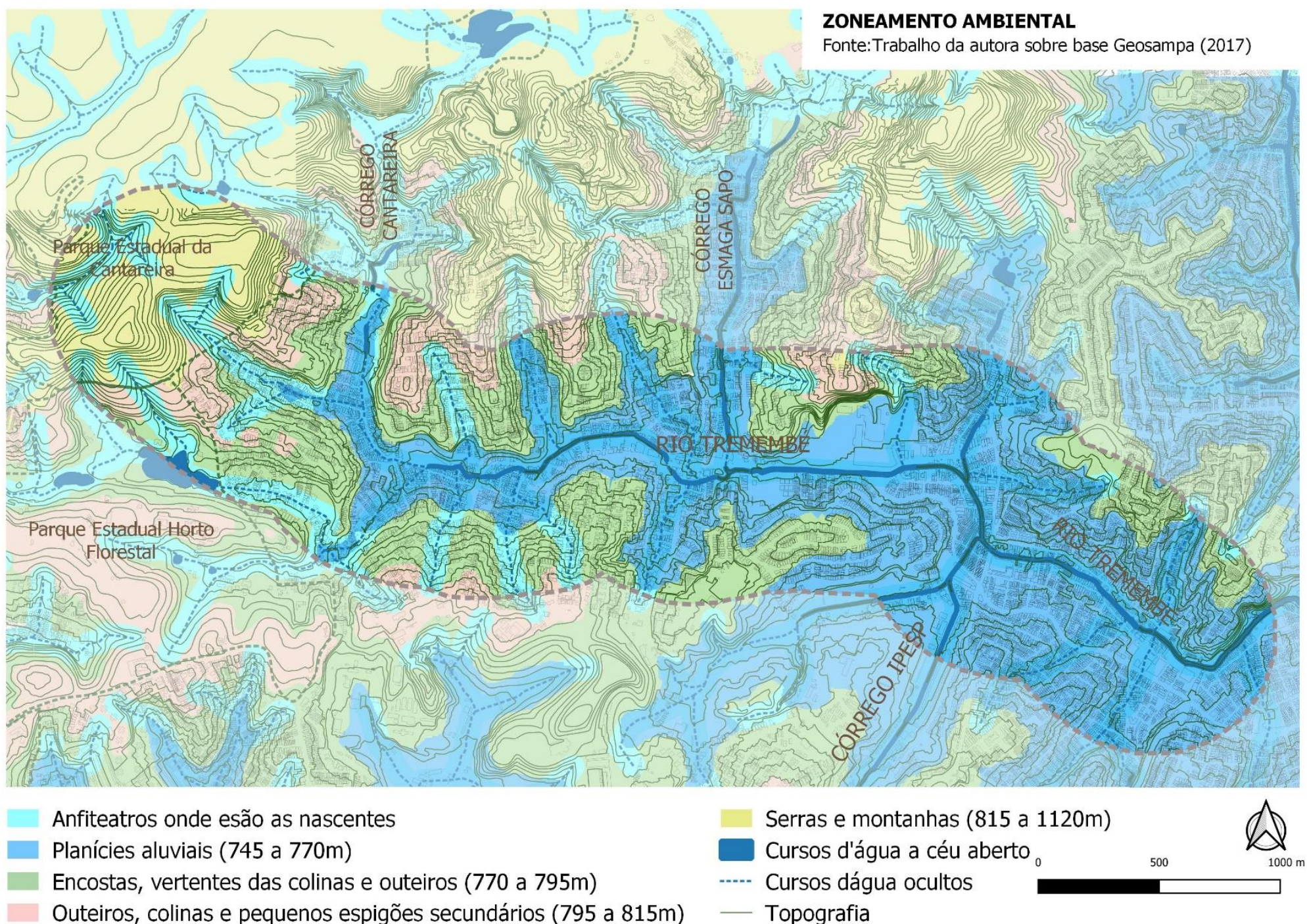

Figura 77- Zoneamento Ambeintal da área de estudo. Fonte: Trabalho da autora sobre base Geosampa. 


\section{Anfiteatros onde estão as nascentes}

As nascentes são situadas em encostas íngremes e conformam verdadeiros anfiteatros de drenagem na parte inferior das vertentes do espigão e das altas colinas. Tidos como "espaços da natureza por excelência", possuem grande importância para o equilíbrio ecológico do ambiente urbano. O processo de escoamento superficial é predominante nesse setor e por isso oferece riscos de erosão, deslizamentos e assoreamento nos canais de drenagem. A sua ocupação não é recomendada e deve ser reservada à constituição de parques com vegetação abundante e áreas livres de lazer para a população.

\section{Planícies aluviais ou várzeas: áreas baixas e planas}

Tidos como os compartimentos das cotas mais baixas, as planícies aluviais ou várzeas recebem a água e os sedimentos dos demais compartimentos. Apresentam seus solos permanentemente úmidos na medida em que o lençol freático dessas áreas se situa entre um e três metros abaixo da superfície. Por esse motivo, apesar do processo de infiltração das águas pluviais ser predominante nas planícies aluviais, a capacidade de infiltração nesse compartimento é restrita. O excesso de água, quando não armazenado, se distribui conformando lagoas, canais e braços de rios. Logo, é uma área propícia ao armazenamento de água temporária ou constante por meio de represamentos. A adoção das bacias de contenção ou detenção deve ser incentivada nessas áreas a fim de conter as cheias, evitar o extravasamento das águas nas várzeas e amenizar os riscos à população nas áreas urbanizadas. Destaca-se também para essas unidades a utilização das lagoas pluviais, que trabalham na filtragem dos resíduos e poluentes carregados pelo escoamento superficial e que podem impedir a poluição dos cursos d'água.

Assim como as nascentes, as várzeas são consideradas "espaços da natureza por excelência" principalmente nos seus trechos estreitos devendo ser ocupados por espaços livres verdes ou por outros que propiciem a retenção de água, como por exemplo as lagoas naturais. Dentre as ocupações recomendadas nesse compartimento, destaca-se o uso institucional nos trechos mais estreitos 
voltados aos espaços públicos e de múltiplo uso. Nos trechos mais largos e amplos as ocupações residenciais, comerciais ou de serviços podem ser introduzidas, desde que se ofereça uma boa permeabilidade do solo nos setores mais elevados (SCHUTZER, 2012).

\section{Encostas, vertentes das colinas e outeiros}

Nesses setores o processo de escoamento superficial é predominante e, por esse motivo, são sensíveis a processos de erosão e deslizamentos. Nesse sentido, é recomendável que estes espaços sejam mantidos em seu estado natural com a utilização de vegetação densa vinculadas à um tratamento do sistema de drenagem eficiente ou mesmo a praças e parques que apresentem técnicas de terraceamento para controle do escoamento superficial.

No contexto da área de estudo, esses espaços apresentam uma ocupação urbana consolidada onde ruas e áreas impermeabilizadas favorecem $\mathrm{O}$ direcionamento de dejetos e poluição para os córregos por meio da água da chuva. Aconselha-se nesta região evitar a alta taxa de impermeabilização aproveitando os espaços livres como jardins e praças que estimulem a infiltração da água no solo. Além disso, a utilização da infraestrutura verde amenizaria os impactos causados pela urbanização, sendo capaz também de restaurar o equilíbrio ecológico nestes compartimentos.

\section{Outeiros, colinas e pequenos espigões secundários}

Nesse tipo de compartimento é necessário incentivar a permeabilidade do solo de maneira a proporcionar o abastecimento do lençol freático e das nascentes. Essa medida também visa reduzir a impermeabilização do solo nessas regiões, o que poderia causar o aumento do escoamento superficial em direção às encostas culminando com a poluição dos cursos d'água e o processo de erosão. As cotas mais altas desse compartimento the conferem boa circulação e ventos, o que contribui para a dispersão de poluentes e refrigeração do ar. 


\section{Relevo montanhoso, serras e montanhas}

Como dito anteriormente, os compartimentos serranos são áreas naturalmente produtoras de água de ótima qualidade e este é tido como o seu principal e mais importante serviço ambiental para a população. A Serra da Cantareira, tida como o principal divisor de águas da Bacia do Alto Tietê, apresenta inúmeros ribeirões responsáveis por dispersar a água para os outros compartimentos da metrópole. As altas declividades desse lugar aliadas à presença de água e densa vegetação the conferem a função de moderador climático com forte influência na circulação do ar, rebaixamento de temperatura e chuvas intensas nas proximidades (SCHUTZER, 2012). A amplitude topográfica da região e as declividades acentuadas do relevo potencializam os processos erosivos nas encostas locais bem como o escoamento superficial. Faz-se necessário, portanto, a conservação da cobertura vegetal nesse tipo de compartimento já que a sua remoção oferece um impacto ambiental aos territórios à jusante.

\subsection{CARACTERÍSTICAS MORFOLÓGICAS E URBANAS DA ÁREA}

\subsubsection{HISTÓRICO DA OCUPAÇÃO}

A área de estudo se localiza predominantemente no distrito do Tremembé, um bairro da zona norte que nasceu nas adjacências do Horto Florestal e que foi assumir uma configuração espacial de caráter mais urbano em meados do século XIX. As primeiras casas de que se tem registro se situavam próximas à estação do Tranway da Cantareira (obra inaugurada em 1893).

Até meados da década de 40 , quase todo o comércio do bairro também se localizava nas proximidades da estação, como bem ilustra a imagem 78 (BRITTO, 1999). Nesse contexto, as estações do antigo Tramway da Cantareira influenciaram na formação de núcleos de povoamento, normalmente mais densos junto delas ou em suas proximidades como mostram as figuras 79 e 80 (AZEVEDO, 1958). 


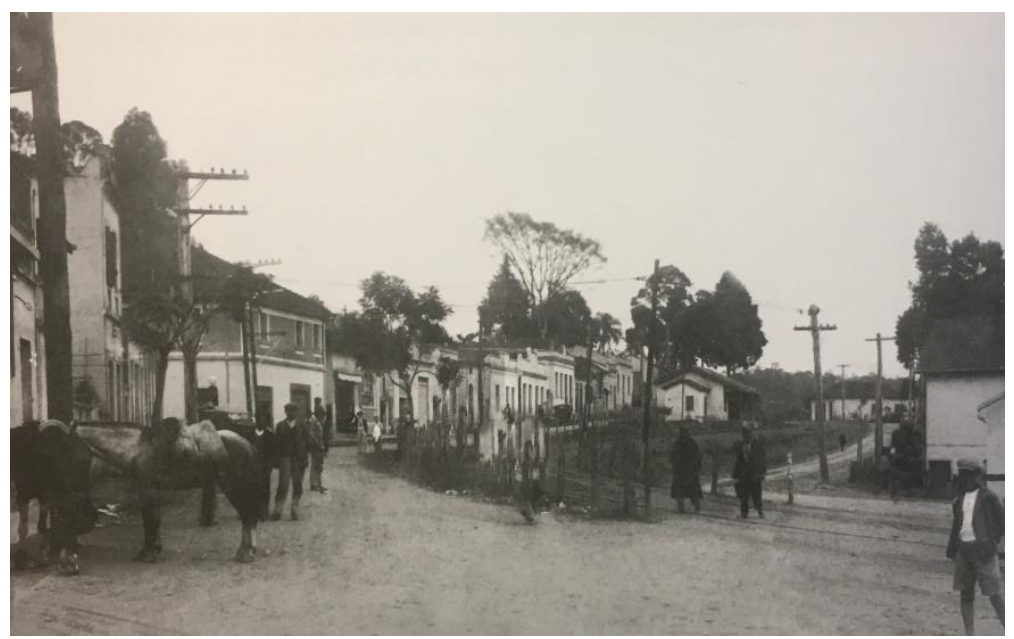

Figura 78- Rua da Estação em 1940, atual Rua Mamud Rahd, origem do bairro Tremembé. Fonte: Gastão João de Nóbrega

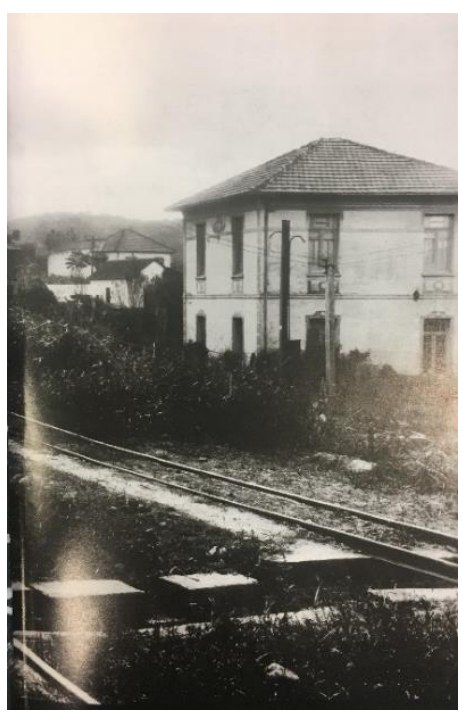

Figura 79- Rua da Estação em 1940, atual Rua Mamud Rahd, origem do bairro Tremembé. Fonte: Alcelino Scalquetti.

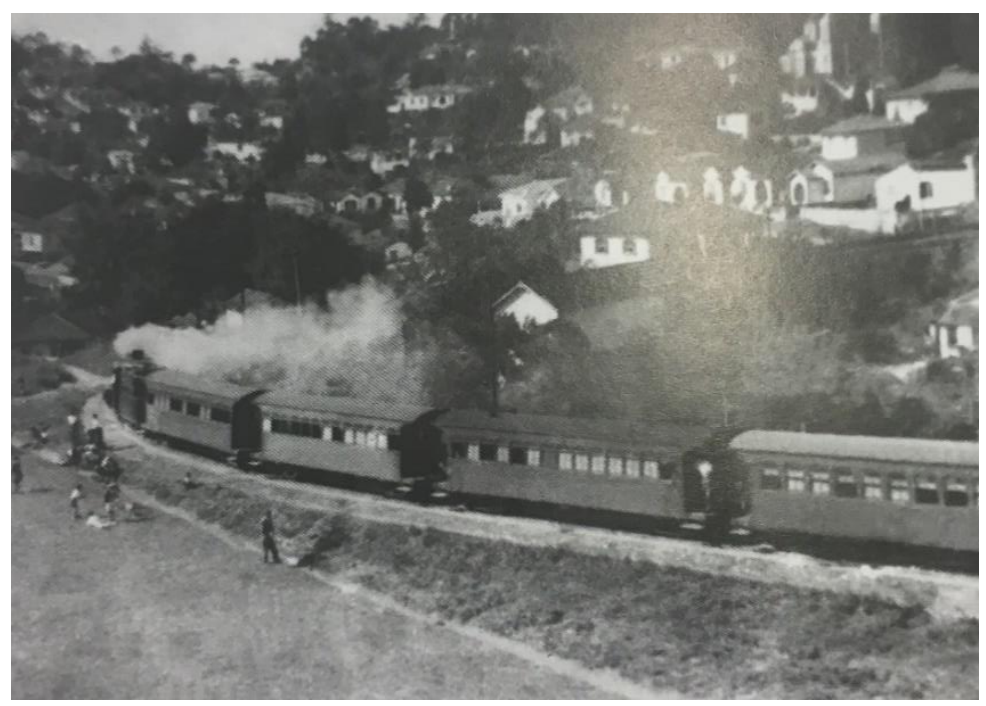

Figura 80- Proximidade do antigo Tramway da Cantareira e núcleos de povoamento. Fonte: Acelino Scalquetti.

O Tramway da Cantareira, que esteve presente na história do Estado de São Paulo entre os anos de 1893 e 1965, realizava a ligação do centro do município de São Paulo à zona norte e, posteriormente, também até Guarulhos (SILVA, 2018). Entre os anos 20 e 30, o "trenzinho da Cantareira", como o meio de transporte também era chamado, consistia na principal ligação da região do Tremembé com o restante da cidade sendo a imagem da máquina a vapor uma lembrança viva na memória de muitos que ainda moram no distrito. A linha 
férrea ${ }^{17}$ foi construída com a principal finalidade de transportar materiais para as obras de captação das águas dos mananciais da Cantareira, incluindo pedras, areia, terra, e, um pouco depois, em 1894, começou a transportar passageirosfunção esta que assumiu protagonismo ao longo de toda a sua história (BRITTO, 1999; SILVA, 2018).

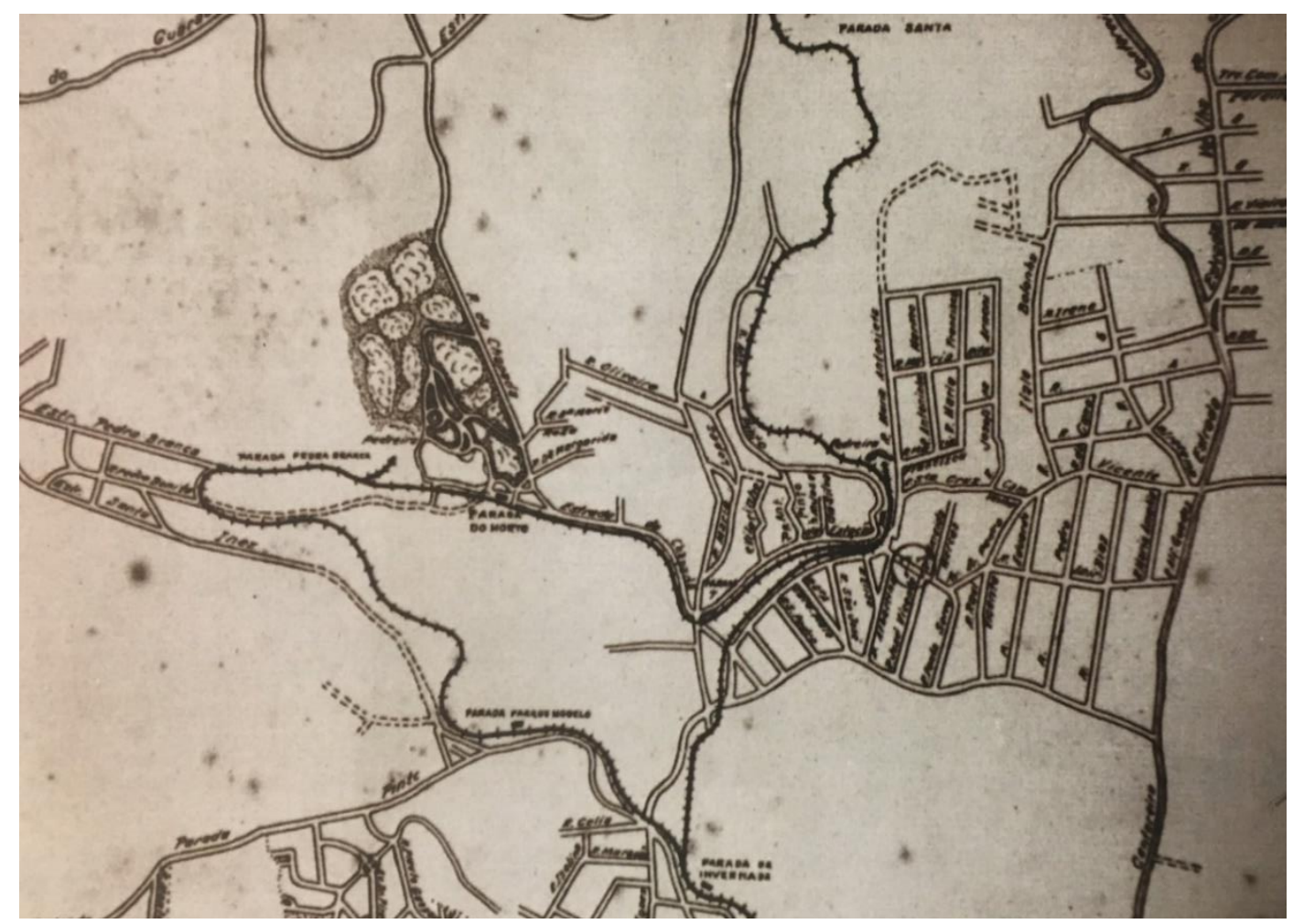

Figura 81- Mapa da Região do Tremembé na década de 40 onde aparece a linha do Tramway da Cantareira e suas estações de parada ${ }^{1}$. Fonte: Oswaldo Nascimento

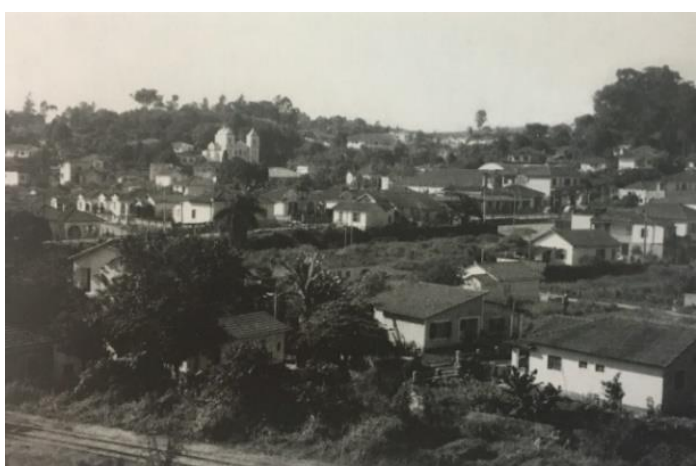

Figura 82- Três planos em 1950: a linha de trem na Rua São Cleto, Largo do Tremembé e a Igreja São Pedro. Fonte: Acelino Scalquetti.

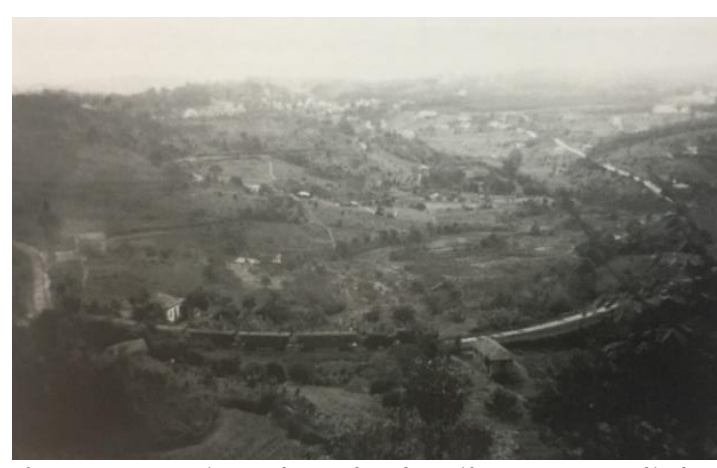

Figura 83- Vista do vale da Vila Rosa e a linha do Tramway, próximo à "Parada Santa". Fonte: Elizabeth Lerche.

17 "Sua trajetória tem como ponto originário o momento em que o governo provincial começou a considerar as águas provenientes dos mananciais da Serra da Cantareira como solução para a crise hídrica enfrentada pelo município de São Paulo, em meados do século XIX, a qual se estendeu ao longo das décadas (...)" (SILVA, 2018, p.27). 
Além do Tramway da Cantareira, o relevo serrano associado a um clima subtropical de alta altitude e a presença marcante da flora também foram fatores responsáveis por cativar as primeiras famílias de imigrantes europeus em meados do século XIX (BRITTO, 1999). Portugueses, italianos e alemães eram atraídos por oportunidades de trabalho e pela paisagem da região que se assemelhava às paisagens europeias. As propriedades eram caracterizadas por relevos sinuosos e arborização marcante que constituíam um cinturão verde como transição em direção à maciça arborização pertencente à Reserva da Cantareira ${ }^{18}$. Aos poucos, as áreas próximas da floresta foram dando lugar a fazendas e pequenas propriedades rurais de maneira a formar bairros consolidados. Ao longo desse tempo a região sofreu consequências decorrentes de uma urbanização desenfreada com o adensamento populacional e construções de grandes condomínios e prédios.

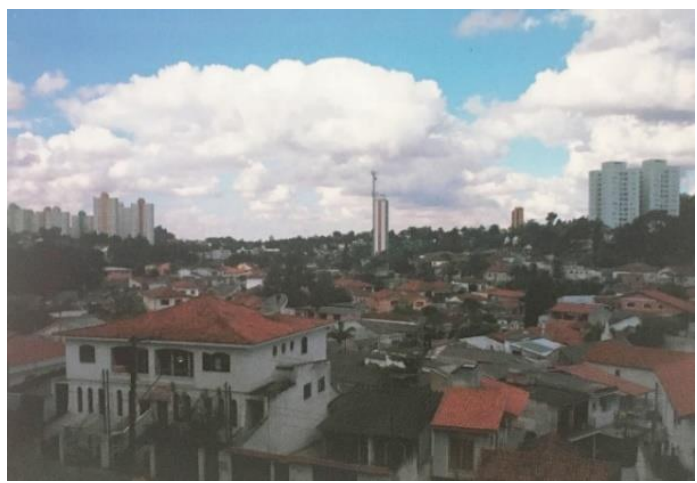

Figura 84- Vista do Tremembé a partir da Av. Luiz Carlos Gentile de Laet". Fonte: Fabio Dianno.

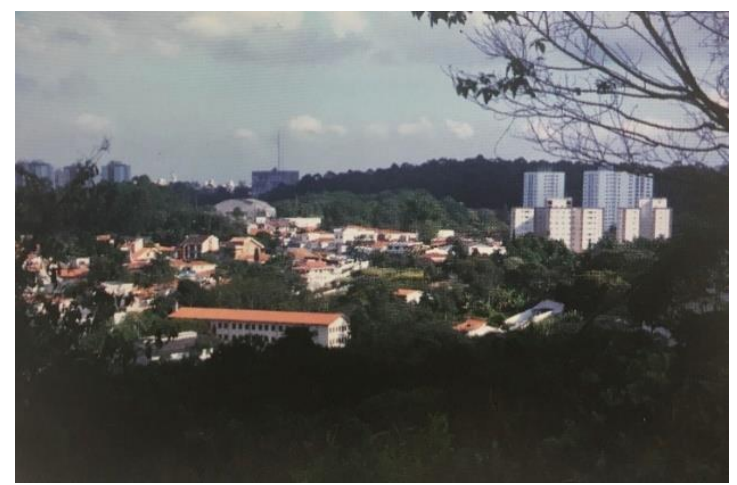

Figura 85- Verde, concreto e nuvens azuis: uma harmonia típica do Tremembé. Vista das Palmas do Tremembé a partir do Jardim Entreserras em 1999. Fonte: Fabio Dianno.

Quanto à origem do nome "Tremembé", estase justifica pela grande presença de água no passado com início nas áreas do Horto, Cantareira, Invernada e pela própria presença do Ribeirão Tremembé que seguia pelo fundo de vale formando muitos cantos com poças e charcos. Assim, a expressão Tremembé se origina do tupi "T-íré-membeg". De $t$, relativo a iérè, "voltear",

18 Documentário "Tremembé meu amor" de Humberto Borges. Disponível em: < https://www.youtube.com/watch?v=oEqb3w3l4il\&t=1184s >. Acesso em 20 de fev. 2019. 
membeg, "afrouxar, derramar", fazendo uma alusão às voltas que o curso hídrico dá, a suavizar-se em alagadiços e poços. Esses poços e alagadiços, que continham águas límpidas há 50 anos, eram utilizados como atividades recreativas como nado e pesca pelos moradores da região (BRITTO, 1999).

A ocupação urbana, que também avançou em direção ao rio Tremembé, contribuiu para a poluição e mesmo desaparecimento dessas várzeas, meandros e lagoas que constituíam a paisagem natural da região. Os córregos que atuam como afluentes e contribuintes do rio Tremembé apresentam hoje ocupação nas suas áreas de várzea com destruição da mata ciliar e canalização em alguns trechos.

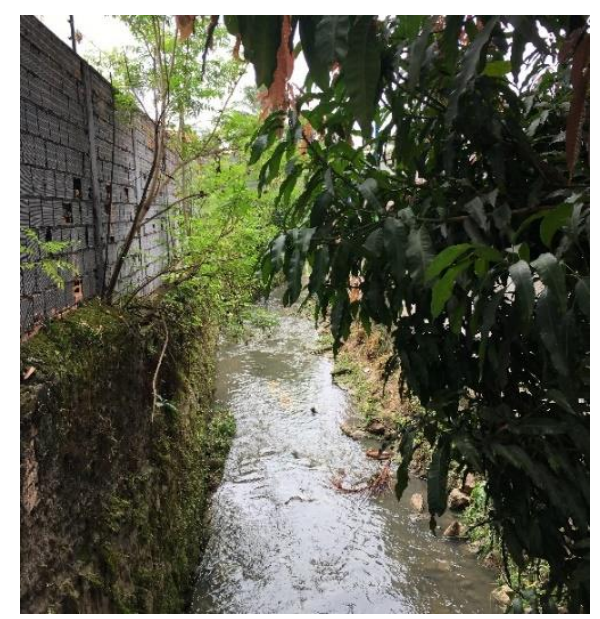

Figura 86- Ocupação das margens do Rio Tremembé, trecho próximo à Rua Professor Pedro Pedreschi. Fonte: Produção da autora (2018).

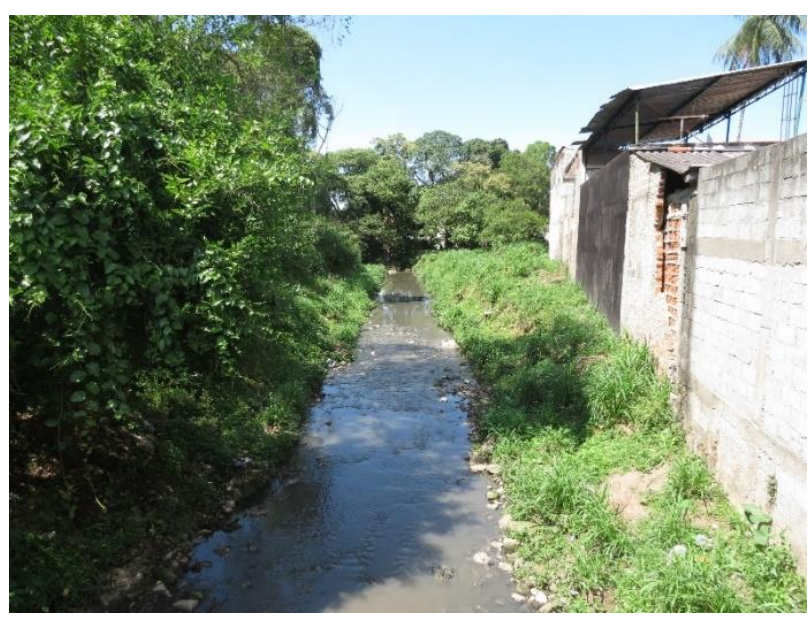

Figura 87- Ocupação das margens do Rio Tremembé- trecho localizado na Rua Agostinho Soares. Fonte: Produção da autora (2019).

\subsubsection{USOS E OCUPAÇÃO TERRITORIAL}

Segundo o Plano Diretor Estratégico da cidade de São Paulo (2014), a área de estudo pertence à duas macrozonas chamadas de "Macrozona de Proteção e Recuperação Ambiental" e "Macrozona de Estruturação e Qualificação Urbana".

A primeira, que está indicada na cor verde e compreende uma porção do Parque Estadual do Horto Florestal e do Parque Estadual da Cantareira (figura 88), é caracterizada por prestar serviços ambientais de extrema importância para 
a sustentação da vida urbana desta geração e das futuras. Suas especificidades geológicas e geotécnicas requerem critérios de ocupação adequados devido a fragilidade ambiental dessa área, admitindo as tipologias de assentamentos urbanos e atividades econômicas de cunho agrícola e de extração mineral. Essa mesma macrozona abrange remanescentes florestais significativos bem como áreas de produção agrícola que proporcionam manutenção da biodiversidade, conservação do solo além de manutenção dos recursos hídricos superficiais e subterrâneos.

A outra macrozona denominada "Macrozona de Estruturação e Qualificação Urbana" indicada na cor cinza já apresenta uma maior diversidade de padrões de uso e ocupação do solo sendo a área do município mais propícia para abrigar usos e atividades urbanos e onde nota-se presença de desigualdade socioespacial.

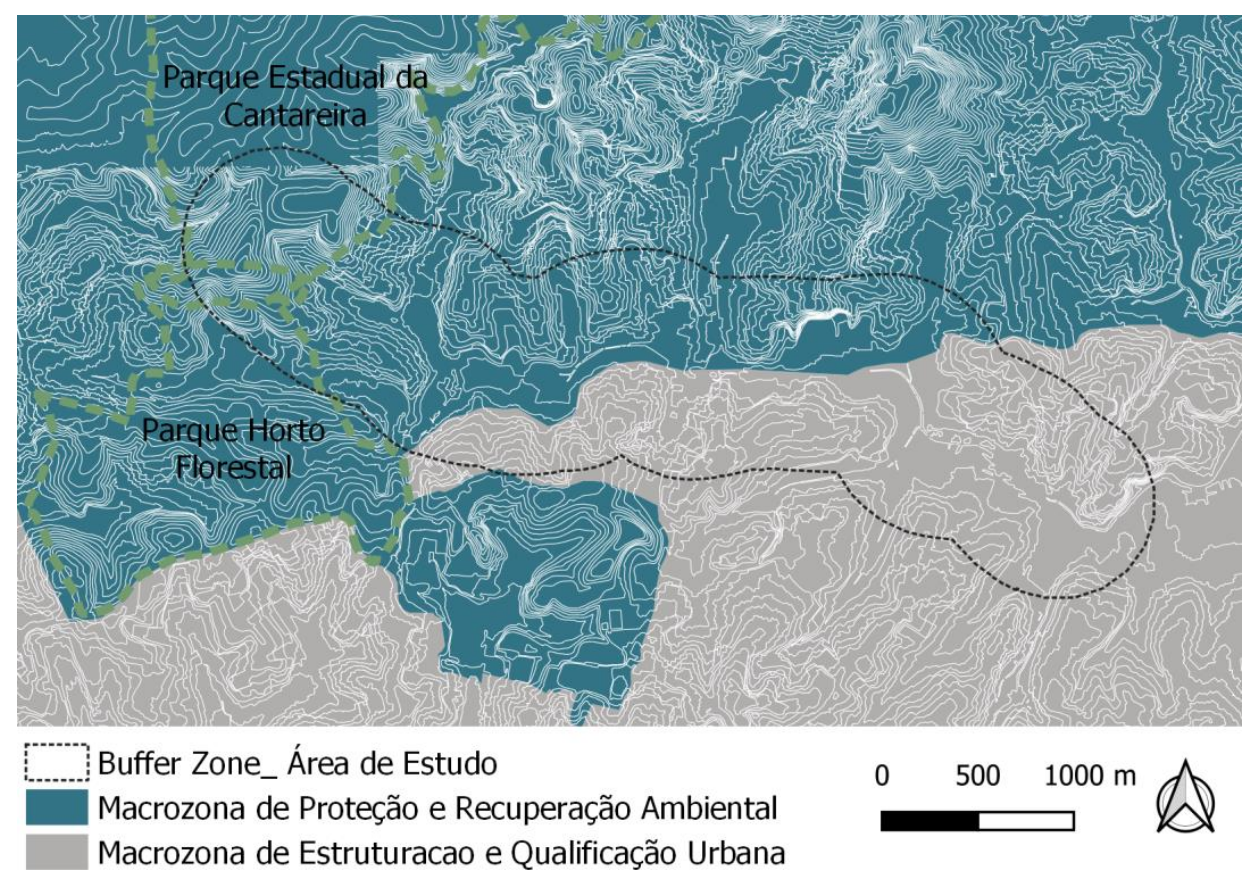

Figura 88- Mapa das Macrozonas do Plano Diretor da cidade de São Paulo (2014) com a área de estudo representada pela linha preta tracejada. Fonte: Trabalho da autora sobre Imagem do Geosampa. 
Com relação às macro áreas, o Plano Diretor Estratégico da cidade de São Paulo (2014) aponta quatro diferentes tipos no enfoque da área de estudo (ver figura 89). Uma pequena porção referente ao Parque Estadual da Cantareira se refere à "Macro área de Preservação de Ecossistemas Naturais", que abrange predominantemente áreas naturais e ecossistemas a serem conservados, de maneira a proporcionar a manutenção da biodiversidade e conservação do solo, das várzeas, cabeceiras de drenagem, nascentes e cursos d'água e áreas de relevo sujeitas a processos erosivos, escorregamentos e outros movimentos de massa.

Outras três macro áreas se fazem presente na área de estudo. A "Macro área de Controle e Qualificação Urbana e Ambiental", que é caracterizada por vazios intraurbanos e distintos padrões de ocupação, predominantemente horizontais. Dentre os diretrizes desta macro área estão a melhoria das condições urbanísticas e ambientais, regularização fundiária dos assentamentos precários e irregulares existentes, contenção da expansão e adensamento, construção de habitações sociais nos vazios intraurbanos e melhoria e complementação do sistema de mobilidade.

Ressalta-se, ainda, a "Macro área de Redução da Vulnerabilidade Urbana" marcada por uma baixa qualidade urbana e ambiental maior que na macro área citada anteriormente, com elevados índices de vulnerabilidade social, presença de população predominantemente de baixa renda que ocupam assentamentos precários e irregulares, riscos geológicos e de inundação bem como déficits na oferta de serviços, equipamentos e infraestruturas urbanas.

Algumas das diretrizes propõem a implementação de serviços, comércios e equipamentos comunitários mediante a participação da população, construção de habitações sociais, regularização fundiária dos assentamentos precários e minimização dos problemas relacionados aos riscos e vulnerabilidade. Por último, tem-se a "Macro área de Qualificação da Urbanização" marcada por usos residenciais e não residenciais espacializados em edificações horizontais e verticais. De acordo com Plano Diretor Estratégico (2014), essa macro área é caracterizada também por um padrão médio de urbanização e pela oferta de serviços e equipamentos. Dentre as diretrizes previstas para esta macro área 
estão controle de adensamento construtivo e melhoria e complementação do sistema de mobilidade urbana.

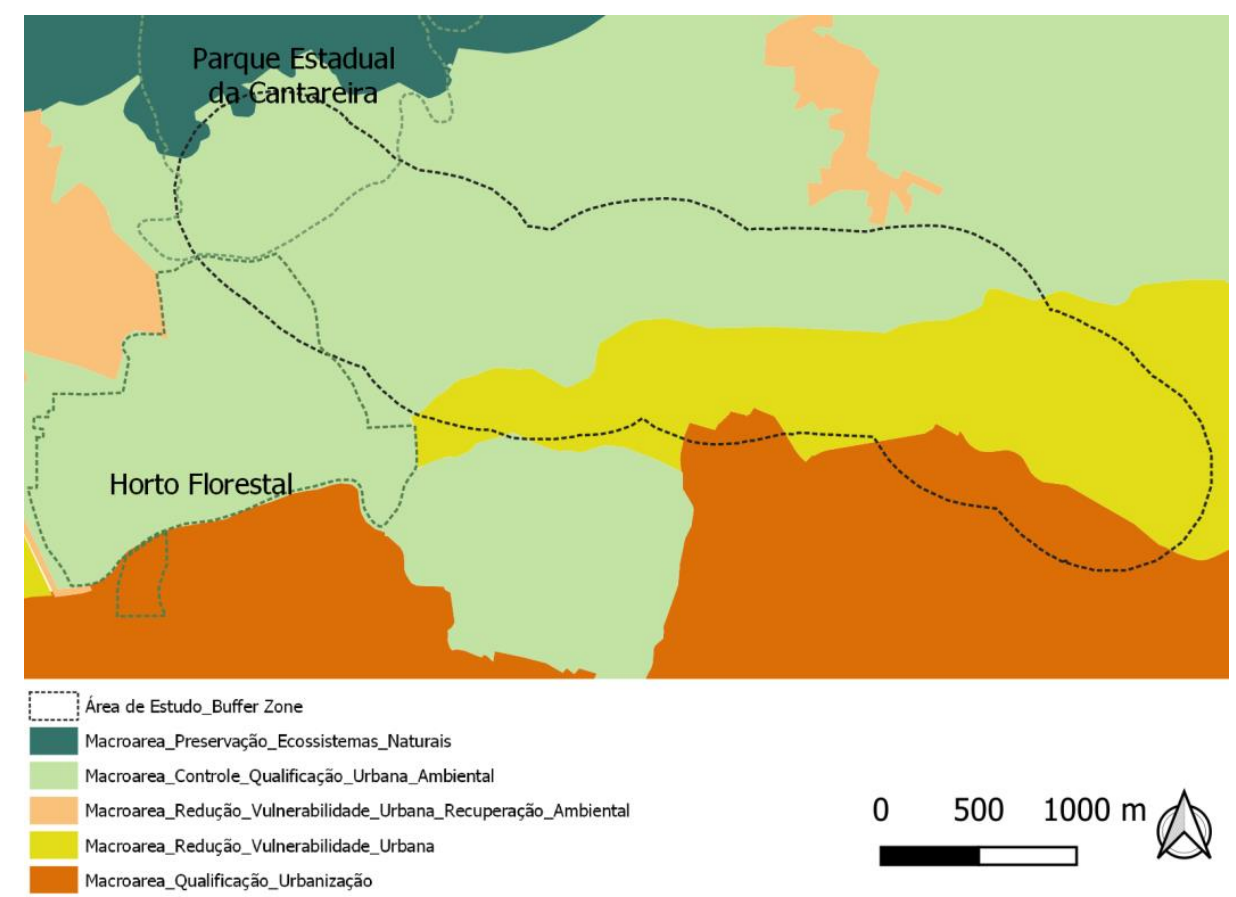

Figura 89- Mapa das Macro áreas do Plano Diretor da cidade de São Paulo (2014) com a área de estudo representada pela linha preta tracejada. Fonte: Trabalho da autora sobre Imagem do Geosampa.

Com relação ao uso do solo, a região de estudo compreende, predominantemente, usos residenciais de médio/ alto padrão identificados na cor amarela no mapa da figura 90. Muitas dessas construções referem-se à chácaras remanescentes da época em que o bairro era procurado como opção de veraneio devido a sua tranquilidade, ar puro e temperaturas agradáveis da região. Além disso, a área em questão engloba também outros tipos de usos residenciais como residencial vertical de médio/ alto padrão, residencial e comércio/ serviços além de algumas poucas residências horizontais de baixo padrão. Entre os outros usos presentes, apesar de bastante escassos e pontuais, estão alguns comércios e serviços e indústrias e armazéns. Ressalta-se, ainda, a presença de equipamentos públicos destacados na cor azul escuro que, apesar de não fazerem parte da área delimitada, localizam-se muito próximos e exercem uma influência direta no enfoque de estudo. 


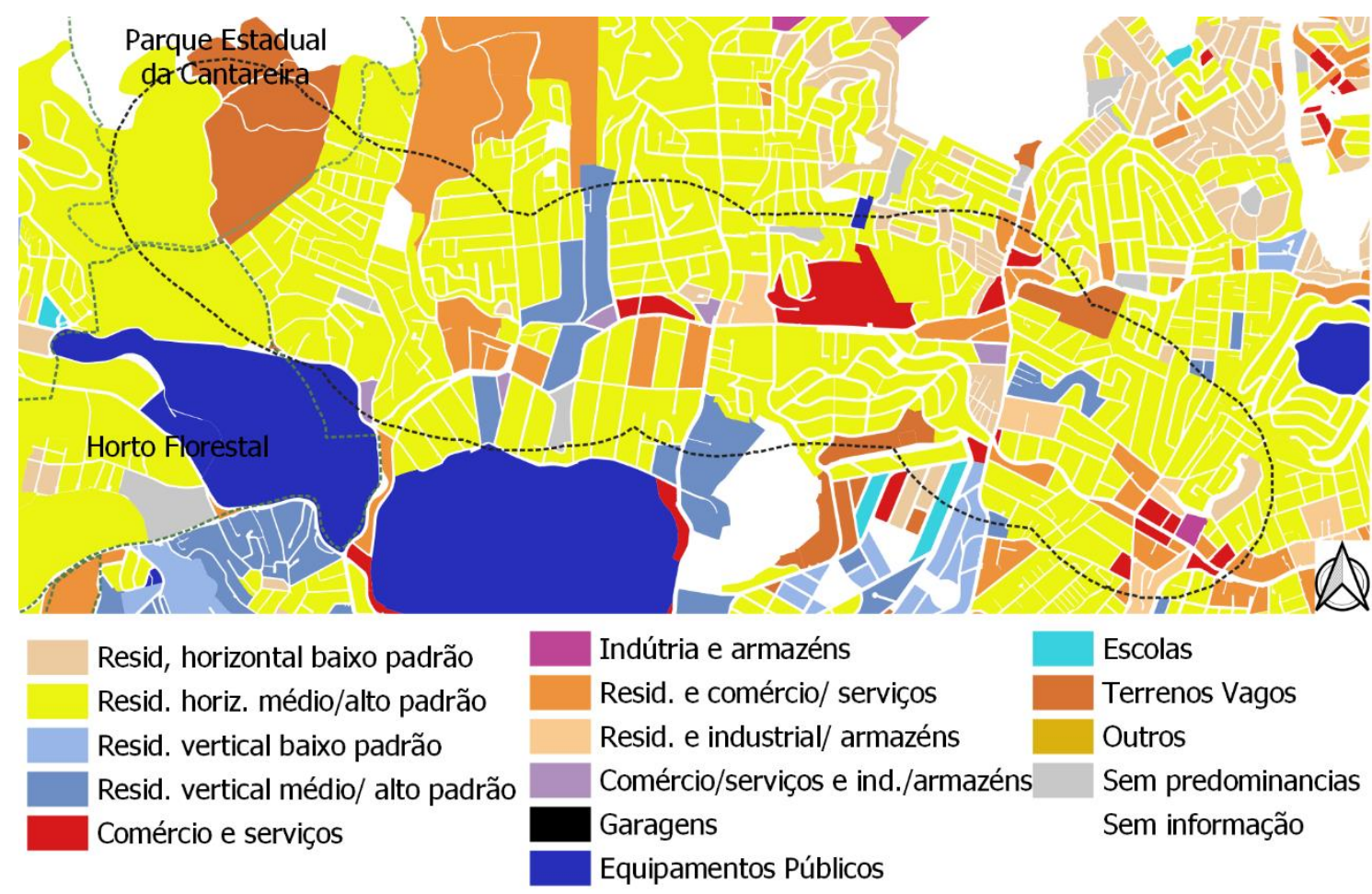

Figura 90- Mapa do Uso e ocupação do solo onde com a área de estudo representada pela linha preta tracejada.. Fonte: Trabalho da autora sobre imagem do Geosampa (2014).

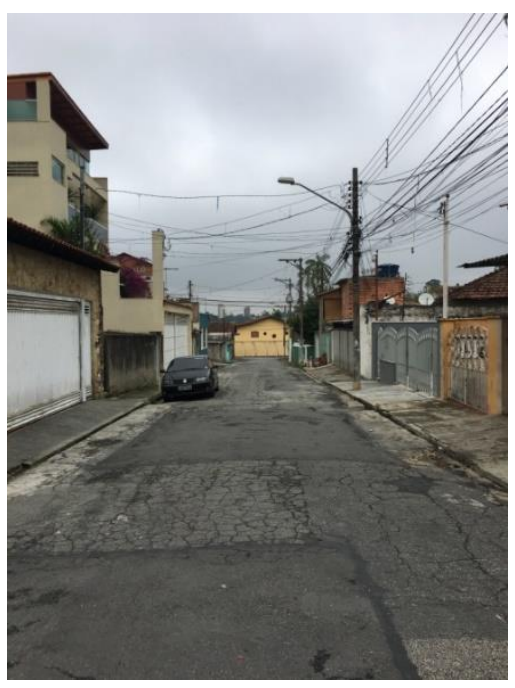

Figura 91- Presença de residência de médio/ alto padrão na Rua Francisco Serrador. Fonte: Fonte: Produção da autora (2018).

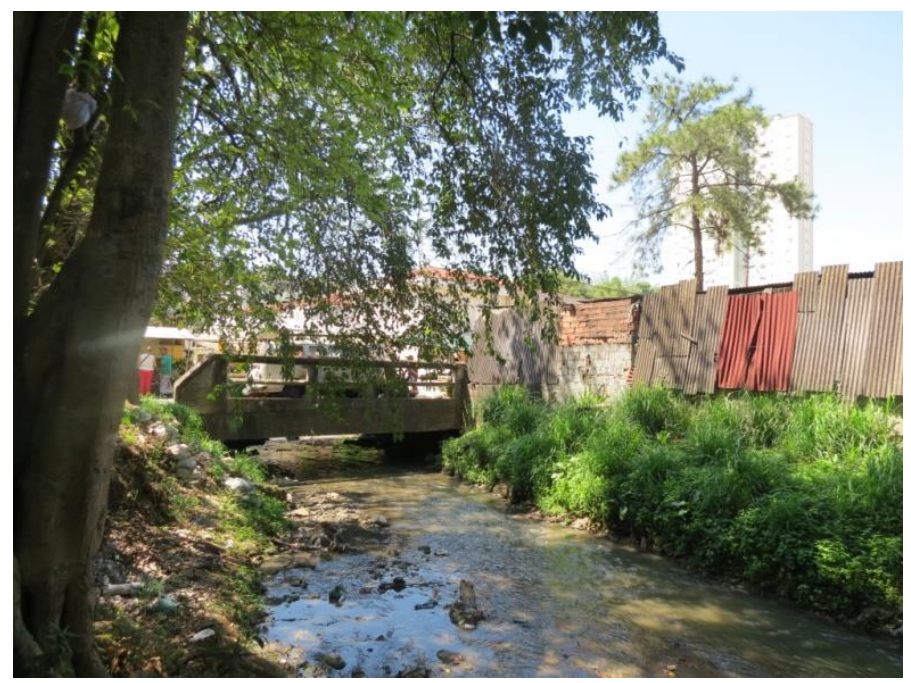

Figura 92 Vista de uma residência horizontal de baixo padrão a partir da Rua Predeschi. Fonte: Laís Leite (2019). Fonte: Produção da autora (2019). 


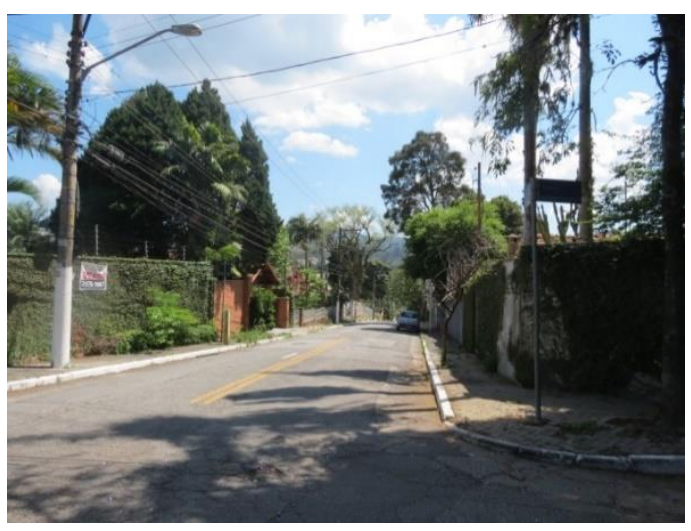

Figura 93- Presença de residências de alto padrão na Rua Lair. Fonte: Laís Leite (2019).

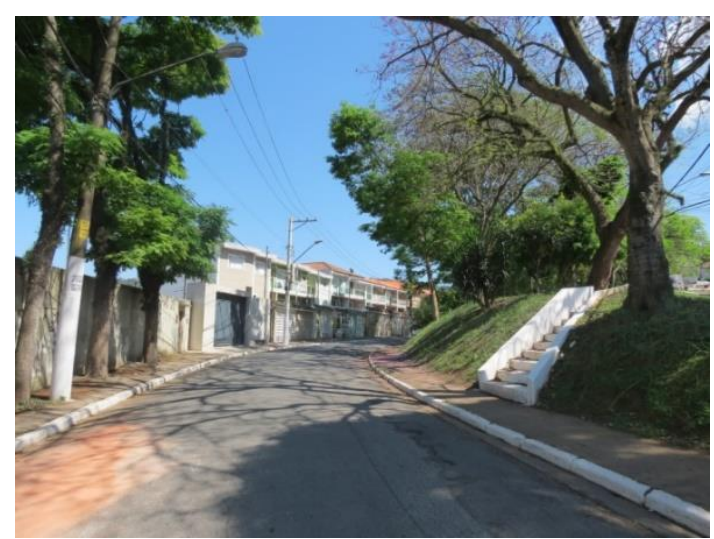

Figura 94- Presença de residências de alto padrão na Rua Lair. Fonte: Laís Leite (2019).

De acordo com o novo zoneamento aprovado em 2017, a área de estudo abrange uma diversidade de zonas como bem ilustra a figura 95 . Os núcleos referentes ao Parque Estadual da Cantareira e ao Parque Estadual do Horto Florestal pertencem à "Zona Especial de Preservação Ambiental" (ZEP), destinada à preservação e proteção do patrimônio ambiental, visto que são duas unidades que prestam relevantes serviços ambientais. Uma outra parte do território pertence à "Zona Mista Ambiental" (ZM a) onde se almeja promover usos residenciais além de viabilizar a diversidade de usos. Nota-se em outros fragmentos do mapa a presença da "Zona Exclusivamente Residencial Ambiental" (ZER A), destinada exclusivamente ao uso residencial de habitações unifamiliares, com baixa densidade demográfica.

Existe a presença de outros segmentos que se referem à "Zona de Centralidade" (ZC) e à "Zona Eixo de Estruturação e Transformação Urbana" (ZEU), em que se pretende incentivar usos não residenciais de forma a promover a qualificação da paisagem e dos espaços públicos, sendo a última pensada para estar articulada com o sistema de transporte coletivo. Outros fragmentos pertencem à "Zona Exclusivamente Residencial"(ZER) com densidade demográfica baixa e, lindeiros a estes, se encontram os lotes que são da "Zona Corredor"(ZCOR) onde se pretende promover usos não residenciais compatíveis com o uso residencial e com a fluidez do tráfego. 
Por último, nota-se ainda na região de estudo, extensões pertencentes às zonas "Zona de Ocupação Especial" (ZOE) que se refere às porções do território destinadas a abrigar atividades que necessitam de uma disciplina especial quanto ao uso e ocupação (por exemplo: aeroportos, centros de convenção, grandes áreas de lazer, recreação e esportes).

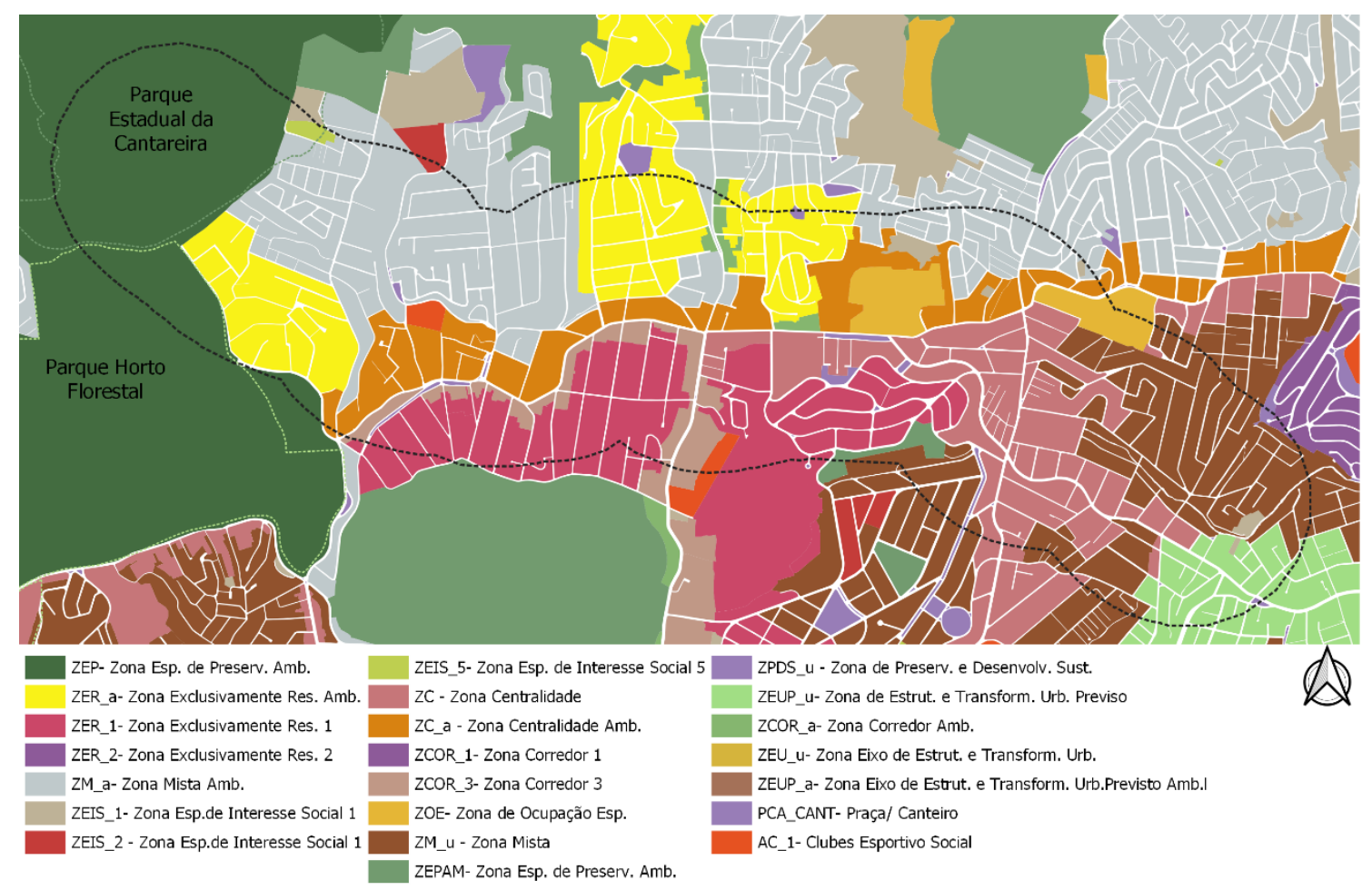

Figura 95- Mapa do zoneamento região com a área de estudo representada pela linha preta tracejada. Fonte: Trabalho da autora sobre imagem do Geosampa (2014).

\subsubsection{INFRAESTRUTURA URBANA}

A área de estudo é cortada no sentido transversal por três importantes vias arteriais, caracterizadas por maiores fluxos de meios de transporte e responsáveis pela conexão com os demais distritos, sendo elas: Av. Luís Carlos Gentile de Laet, Av. Nova Cantareira e Av. Coronel Sezefredo Fagundes. No sentido longitudinal, tem-se a via arterial Amália Lopes de Azevedo que prossegue até o limite do distrito Tremembé. Nota-se também a presença de vias coletoras que fazem a ligação da região com a porção mais acima pertencente ao distrito Tremembé, além de realizarem também a conexão com a Rodovia Fernão Dias (Figura 96). 


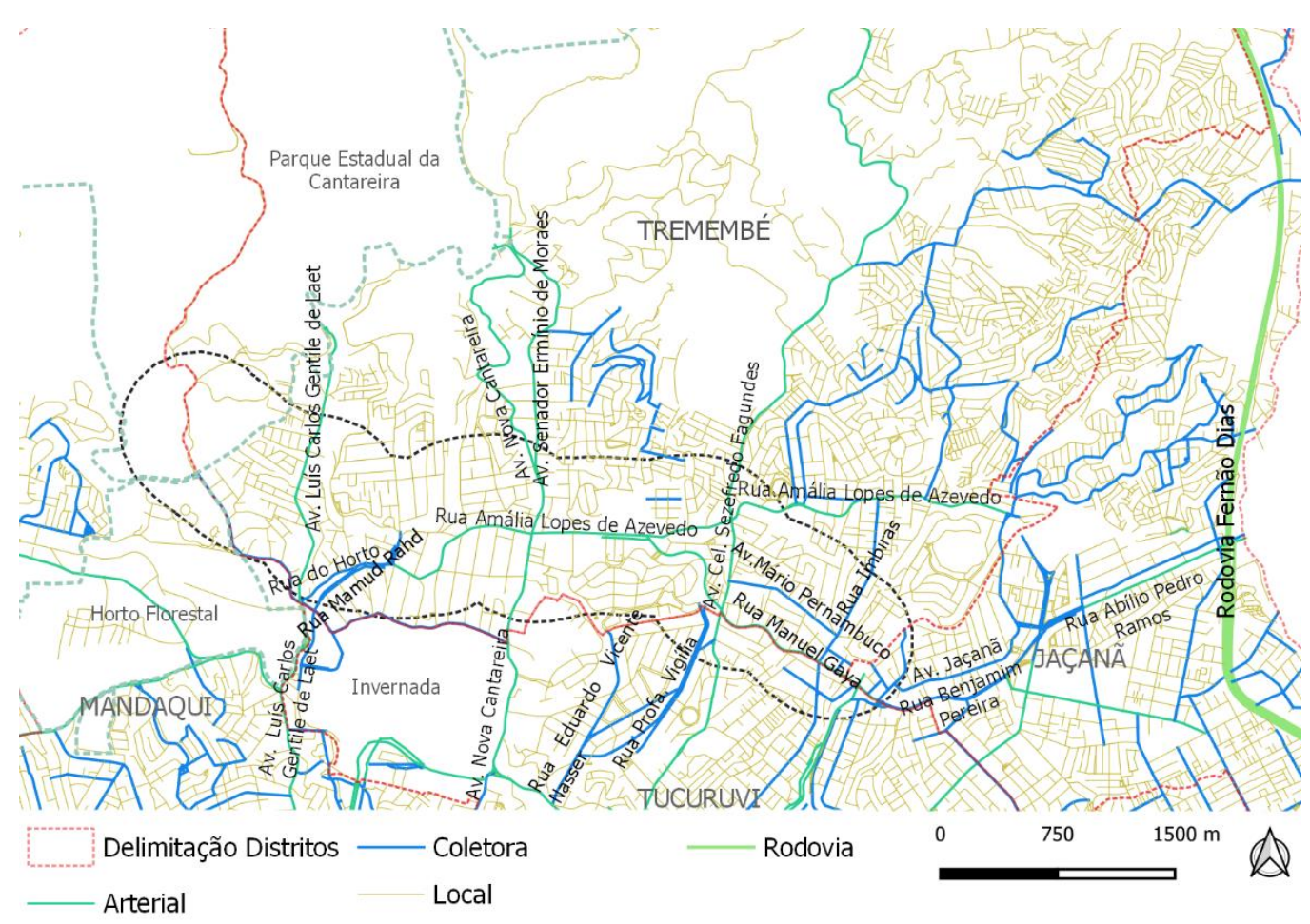

Figura 96- Mapa com indicação da classificação viária da região com a área de estudo representada pela linha preta tracejada. Fonte: Fonte: Trabalho da autora sobre Imagem do Geosampa .

Com relação ao cenário da mobilidade urbana na região de estudo, verificou-se a presença de 6 (seis) linhas de ônibus, estas concentradas nas avenidas arteriais que servem o distrito do Tremembé. As faixas direcionadas para ônibus aparecem em parte na Av. Cantareira, com continuidade na direção sul e fazendo a conexão com os distritos Tucuruvi e Santana. No limite da buffer zone nota-se o início de outra faixa de ônibus que segue pelas vias coletoras José Benjamim Pereira e Abílio Pedro Ramos com destino à Rodovia Fernão Dias, esta última situada na divisa do município de Guarulhos e reconhecida como a principal ligação entre as cidades de São Paulo (SP) e Belo Horizonte (MG) (Figura 97).

O distrito Tremembé não conta com a presença de terminais de ônibus, trem ou metrô, enquanto o terminal de ônibus mais próximo se apresenta no distrito Casa Verde e a estação de metrô, por sua vez, no distrito Tucuruvi. No entanto, as linhas de ônibus do distrito Tremembé pertencentes às vias coletoras assumem uma grande importância, uma vez que realizam a ligação da região de 
estudo até estes equipamentos urbanos. Quanto à oferta de malha cicloviária, esta apresenta-se ausente na escala local, sendo a rede mais próxima localizada a aproximadamente $1,7 \mathrm{~km}$, com início a partir da Invernada da Polícia Militar e com continuidade em direção aos outros distritos na direção sul.

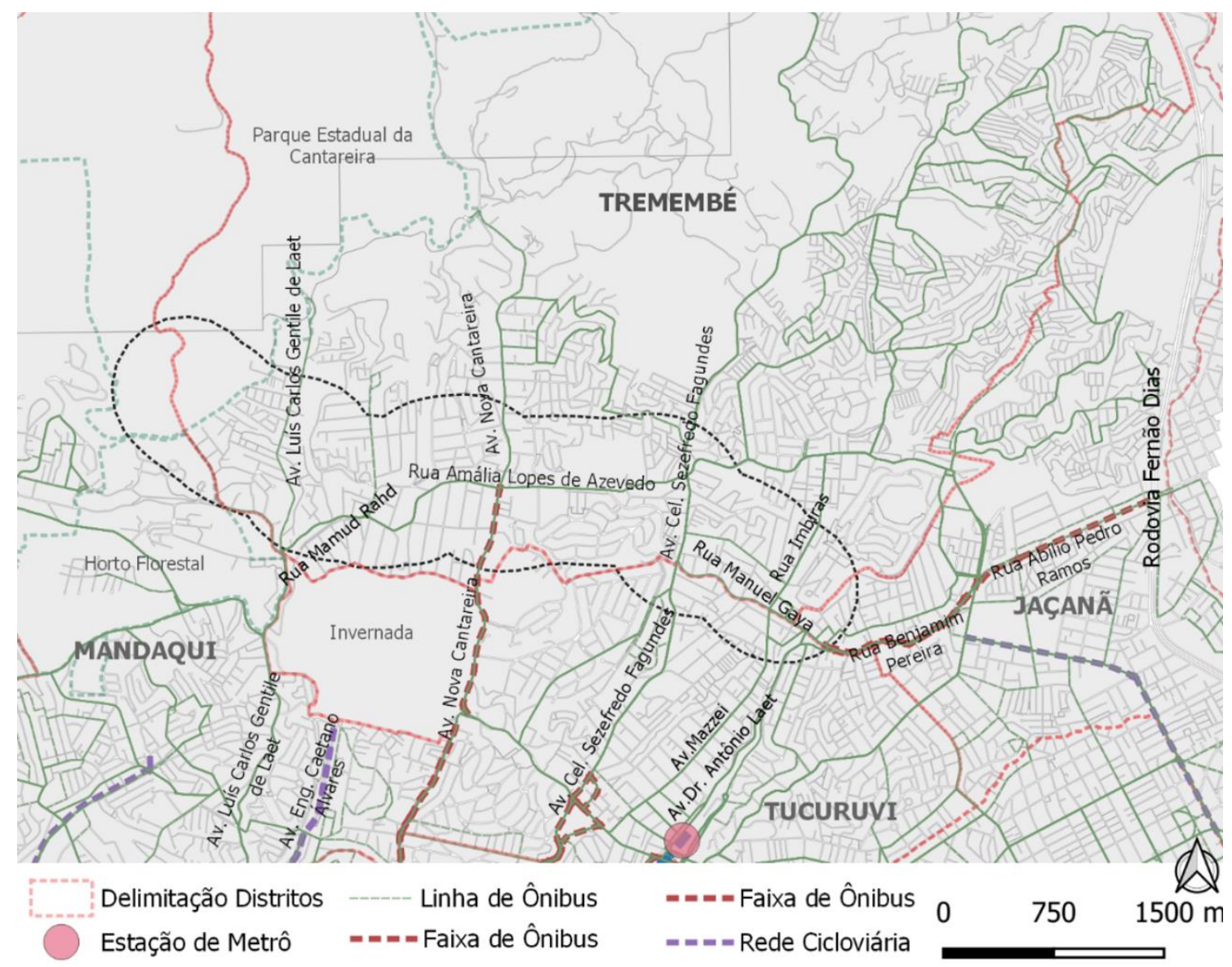

Figura 97- Mapa de mobilidade da região com a área de estudo representada pela linha preta tracejada. Fonte: Fonte: Trabalho da autora sobre Imagem do Geosampa.

Considerando a região de estudo delimitada, verifica-se a presença de alguns equipamentos urbanos que atendem a escala local e que proporcionam relevantes serviços para a população. Dentre esses equipamentos foi possível identificar a Igreja São Pedro do Tremembé, as UBS's (Unidades Básicas de Atendimento) Tremembé e Mariquinha Sciáscia, feiras livres de bairros, o Parque Municipal Sena (antiga praça Coronel José Pedro de Castro) além das praças intituladas como Antônio Arnoni, Francisco Machado, Dona Mariquinha Sciascia e Rafael Vital. 


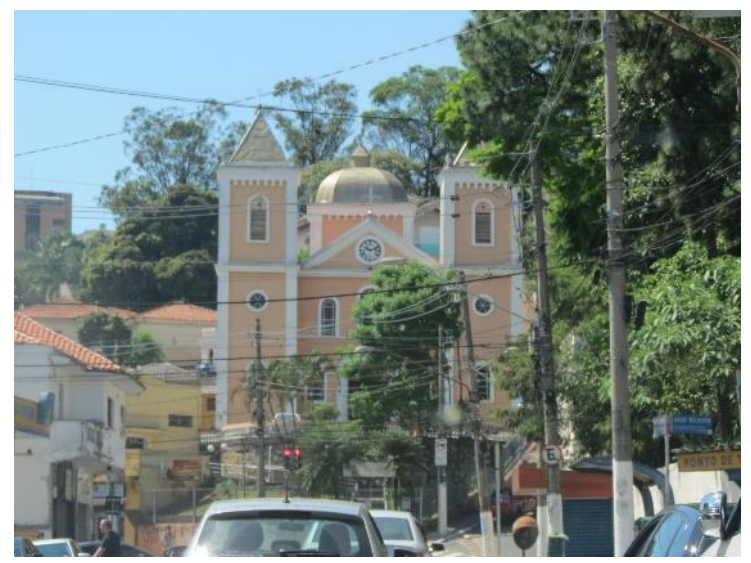

Figura 98- Igreja São Pedro na Rua Amália Lopes de Azevedo. Fonte: Produção da autora (2019)

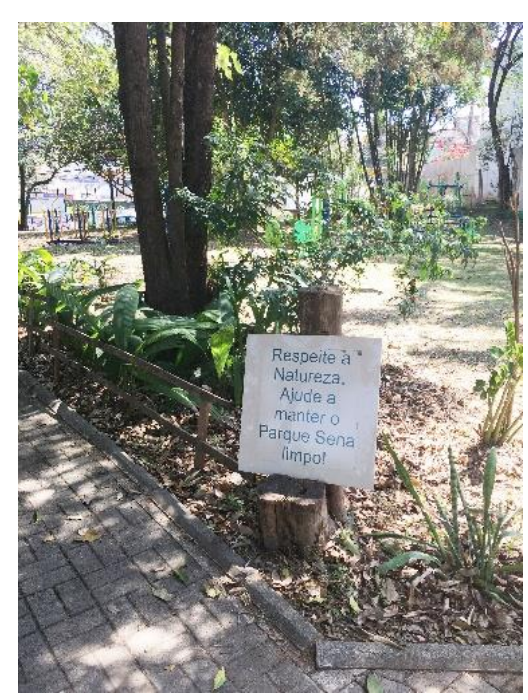

Figura 100- Parque Sena. Fonte: Produção da autora (2019).

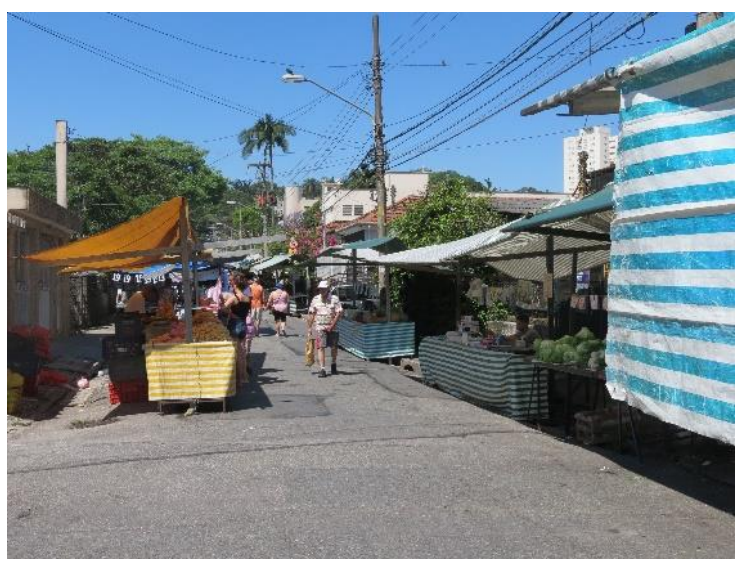

Figura 99 Feira livre de bairro. Fonte: Produção da autora (2019)

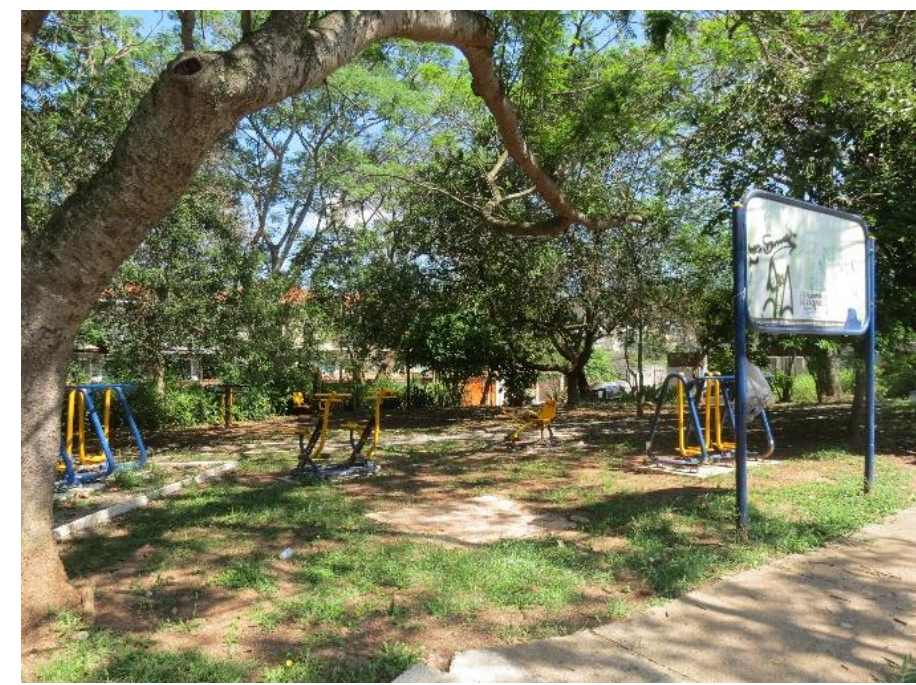

Figura 101- Praça Antônio Arnoni. Fonte: Produção da autora (2019).

Notou-se também a presença de alguns equipamentos particulares relacionados à assistência social como o "Abrigo dos Velhinhos Frederico Ozanan" e o "Recanto Nossa Senhora de Lourdes". O distrito do Tremembé como um todo também apresenta a incidência de unidades voltadas para esse tipo de serviço, fato que pode ser justificado por fatores geográficos. A riqueza de vegetação, água em abundância e clima temperado fez com que o bairro fosse um destino muito propício à instalação de clínicas e casas de repouso para idosos, usufruindo das amplas casas e chácaras remanescentes (BRITTO, 1999).

A área de enfoque também abarca muitos equipamentos voltados para a educação como escolas de rede pública infantil, rede pública de ensino 
fundamental e médio e escolas da rede privada. Além disso, ressalta-se a presença da "Casa de Cultura Tremembé" como um equipamento de cultura e o CAT (Centro Atlético de Treinamento) como um equipamento de esporte. Para além dos limites da área de estudo, destaca-se o Parque Estadual da Cantareira e o Horto Florestal os quais oferecem serviços de lazer relevantes.

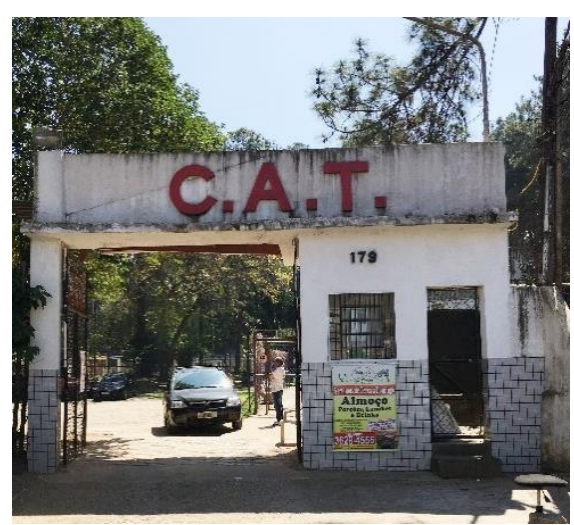

Figura 102- Centro Atlético do Tremembé. Fonte: Laís Leite (2018).

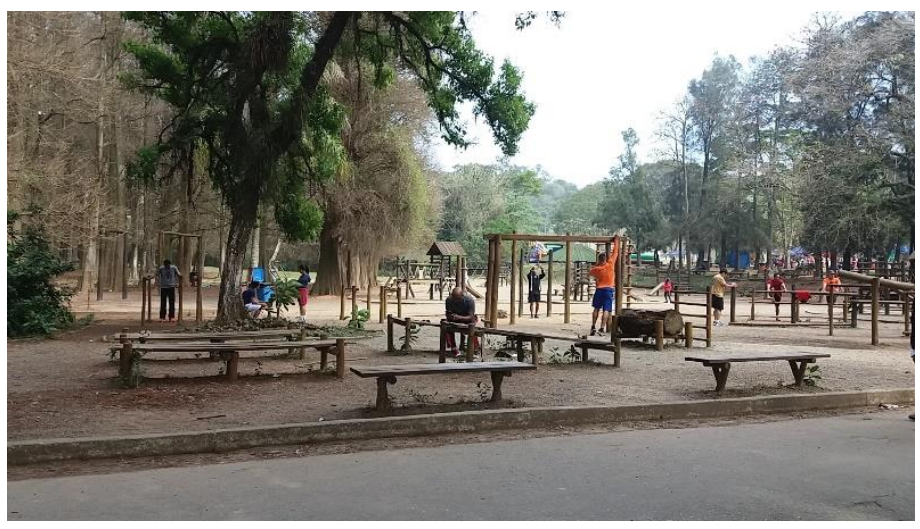

Figura 103- Núcleo de recreação no Parque Horto Florestal. Fonte: Laís Leite (2019). 


\section{CAPÍTULO 4}

\section{AS INFRAESTRUTURAS URBANAS TRADICIONAIS}

"Um ato é certo quando tende a preservar a integridade, a estabilidade e a beleza da comunidade biótica. Ele é errado quando tende a fazer o contrário" (Aldo Leopoldo, 1949)

Definidas como o palco principal das dinâmicas ou atividades humanas, as cidades admitiram com o tempo a expansão dos seus assentamentos urbanos, em prol do desenvolvimento econômico e das necessidades advindas daqueles que as habitam. O aumento populacional com consequente ampliação do território urbano culminou com a necessidade progressiva por mais serviços e, consequentemente, por uma infraestrutura que suprisse estas ofertas.

Nesse processo, as áreas vegetadas foram cedendo espaços para a construção de edificações enquanto corpos hídricos sofriam processos de retificação e tamponamento para dar recinto às novas vias. Muitos elementos que antes eram capazes de ofertar serviços advindos de sua essência natural, como várzeas, vegetação e rios foram substituídos pelos sistemas de infraestrutura convencionais, os quais, ainda que fielmente implantados, têm revelado uma capacidade bastante restrita para atender os desafios da população em massa (BELÁGER, 2009).

De acordo com Beláger (2009), os projetos de infraestrutura convencionais assumiram ao longo da história uma abordagem monofuncional de maneira a segregar água, lixo, transporte, alimentos e energia em setores diferentes sem qualquer ligação, separação esta que tem se mostrado cara e ineficaz.

Moss (2001) complementa a limitação desse modelo de infraestrutura ao abordar que, embora fundamentadas e justificadas em modelos matemáticos, não consideram a complexidade e imprevisibilidade que de fato delineiam 
realidade. Ao almejar a universalidade, as redes de infraestrutura convencionais generalizam a mesma solução técnica para diferentes contextos e por não considerarem as peculiaridades naturais do meio, não são capazes de conseguem tirar proveito destas ou permitirem associações com outros tipos de tecnologias (PELLEGRINO, 2017).

Apesar dos efeitos negativos das infraestruturas convencionais delineados, este ainda consiste no modelo mais adotado nas atuais cidades que priorizam a todo custo a economia baseada no indivíduo e no consumo intensivo. Para atender suas necessidades, a cidade moderna é marcada pelas grandes aberturas no tecido urbano permitindo o alargamento das ruas e construção das vias expressas que se expandem pelo território sem limites (HERZOG, 2013).

Em prol de um fluxo de automóveis mais eficiente, as áreas vegetadas foram ignoradas, áreas úmidas e alagáveis passaram a ser subjugadas e muitos corpos hídricos foram canalizados tornando-se ocultos na paisagem urbana. Em paralelo, a drenagem urbana subterrânea em galerias de águas pluviais ganhou força, realizando o escoamento superficial rápido e o mais longe possível sem considerar enchentes e outros impactos à jusante (HERZOG, 2013). Dessa maneira, as necessidades impostas pelo livre mercado intensificaram a adoção dos modelos de infraestrutura convencionais com a transformação das áreas naturais e sua biodiversidade colocando em xeque a sustentabilidade ambiental de cada localidade.

Spirn (1995) em sua obra "O Jardim de Granito" descreve o cenário típico relacionado ao regime hídrico em uma área urbana, reconhecido pelo escoamento abundante e rápido na ocorrência de temporais, com altas vazões de água durante e imediatamente após as chuvas. Evidencia-se, além da ocorrência de enchentes, problemas como o grau de poluição elevado e a presença de pavimentos e bueiros que reduzem a infiltração de água no solo. $\mathrm{Na}$ ocasião, a autora explica que esses entraves podem ser considerados frutos relacionados aos aspectos da forma urbana, materiais impermeabilizados empregados, padrões de assentamento e tipos sistemas tradicionais de drenagem empregados (SPIRN, 1995). 
O fato é que, durante muito tempo, a drenagem urbana foi pouco reconhecida enquanto fator preponderante no planejamento e durante expansão desenfreada das cidades, o que gerou problemas hídricos bastante preocupantes.

No contexto do Brasil, a frequência e gravidade das inundações estão presentes em algumas cidades como Rio de Janeiro, Belo Horizonte e São Paulo. Em prol da urbanização e do desenvolvimento, as várzeas dos rios destas localidades foram dominadas pelo sistema viário dando origem às vias de fundo de vale. Para isto, a função ambiental dos córregos foi ignorada os quais passaram pelos processos de retificação, canalização ou enterramento em galerias, a fim de possibilitar as construções viárias. Em decorrência desses processos, as várzeas dos antigos meandros foram eliminadas o que causou, além da aceleração dos escoamentos, um aumento notável dos picos de vazão e, como consequência, das inundações (CANHOLI, 2014).

Em períodos de chuva, os habitantes da cidade de São Paulo vivenciam há décadas transtornos e tragédias relacionados ao grande volume de água e a incapacidade de retenção pelos seus sistemas de drenagem. Quando não ocultos pelas vias de tráfego, os rios urbanos muitas vezes são transformados em condutores de esgotos a céu aberto. Dessa forma, quando ocorre o transbordamento dos rios em virtude das grandes chuvas, além de causar danos que impactam o tráfego, moradia e serviços, os corpos hídricos também se tornam responsáveis pela disseminação de doenças pela água contaminada (CANHOLI, 2014).

Problemas como esse existem em decorrência do tipo de planejamento e apropriação da paisagem ao longo do desenvolvimento urbano da metrópole, marcado pela rápida transição rural- urbana e que privilegiou a ocupação de suas planícies fluviais. Com um número aproximado de 31 mil habitantes em 1872, São Paulo verificou sua população multiplicar sete vezes até o final do século, obtendo o título da principal metrópole da América do Sul já na segunda metade de século XX (SMDU, 2012). Atualmente, a área metropolitana abrange mais de 20 milhões de habitantes e insere-se nos limites topográficos de uma única bacia denominada Bacia do Alto Tietê. que apresenta como principal corpo d'água o Rio Tietê. Além de possuir altos índices pluviométricos, a bacia em pauta se situa 
em uma cabeceira e apresenta solo poroso, com capacidade baixa para reter as águas pluviais (ABRIL, 2017).

As particularidades da grande rede de drenagem da Bacia do Alto Tietê aliadas à velocidade do processo de urbanização da metrópole com impermeabilização do solo e supressão de suas várzeas (seja por ocupações irregulares e precárias ou por grandes empreendimentos e infraestruturas urbanas) provocaram os sérios problemas relativos ao manejo das águas superficiais na região metropolitana. Diante das adversidades sentidas, o ano de 1990 conta com algumas soluções alternativas de drenagem urbana, culminando com o Plano Diretor de Macrodrenagem da Bacia do Alto Tietêt19 (ABRIL, 2017).

Dentre as intervenções previstas para reduzir os efeitos das cheias, o Plano conta com medidas estruturais incluindo a canalização de corpos hídricos e artifícios de retenção e contenção das águas, conhecidos popularmente como piscinões. Nessa direção, a progressiva impermeabilização das bacias hidrográficas de São Paulo associada à uma ausência de uma visão mais integrada no que tange à dinâmicas hidrográficas naturais do território levou à implantação de soluções pontuais e localizadas, apenas transferindo o problema para outra localidade e gerando áreas inundadas à jusante (ABRIL, 2017).

\subsection{ALTERAÇÕES NA DINÂMICA DA PAISAGEM: PLANOS E PROJETOS URBANOS PREVISTOS PARA A ÁREA DE ESTUDO E ENTORNO}

Os efeitos deste modelo de infraestrutura tradicional merecem ser discutidos na área de enfoque deste trabalho, que hoje já vislumbra os futuros

\footnotetext{
19 O Plano Diretor de Macrodrenagem da Bacia do Alto Tietê (PDMAT) consiste em um instrumento norteador e estratégico na definição de políticas e obras públicas voltadas à macrodrenagem do Alto Tietê. Foi elaborado pelo Departamento de Água e Energia Elétrica (DAEE). Sua primeira versão pertence ao ano de 1988 com ações continuadas no PDMAT -2, concluído em 2010. Atualmente o plano segue na sua terceira etapa de elaboração pelo PDMAT-3, iniciado no ano de 2011 que apresenta como objetivo " diagnosticar e analisar o atual sistema de macrodrenagem da RMSP e propor um conjunto de soluções capazes de reduzir os efeitos das cheias com resultados para os horizontes de cinco, dez e vinte anos" (DAEE, 2014).
} 
impactos ambientais de duas construções já em andamento denominadas: "Obra do Trecho Norte do Rodoanel Mário Covas" e "Obras para Controle de Inundações da Bacia do Córrego Tremembé".

A relevância ecológica da área de enfoque deste trabalho localizada na bacia hidrográfica do Tremembé, já abertamente discutida, se pauta na sua grande proximidade com a área núcleo do cinturão verde da Serra da Cantareira ao norte de São Paulo, além de apresentar em suas adjacências outras manchas verdes relevantes com o Parque Estadual Horto Florestal. Soma-se à existência das áreas vegetadas a presença da rede hídrica conformada pelo Rio Tremembé e seus afluentes que, juntos, também conferem importante valor ambiental à área estudo. Diante disso, as obras em curso oferecem impactos e ameaças à integridade das dinâmicas naturais de funcionamento do território de enfoque e, por isso, requerem devida atenção.

\subsubsection{OBRA DE CONTENÇÃO DE ENCHENTES NA BACIA HIDROGRÁFICA DO TREMEMBÉ}

Dentre as intervenções traçadas pelo Plano Diretor de Macrodrenagem da Bacia do Alto Tietê, algumas tiveram como alvo a Bacia Hidrográfica do Rio Tremembé, situada na zona norte do município de São Paulo e que compreende a área de estudo em pauta desta pesquisa. A bacia hidrográfica em questão passou por intervenções que favoreceram a urbanização e eliminaram as características naturais da rede de drenagem. Ainda que englobe extensões permeáveis consideráveis referentes ao Horto Florestal, Parque Estadual da Cantareira e outros fragmentos remanescentes da Mata Atlântica, a área sofre problemas relacionados à drenagem das águas pluviais com transtornos à população e ao município (SIURB, 2015). 
Por este motivo, a área foi contemplada com empreendimento "Obras para Controle de Inundações da Bacia do Córrego Tremembé"20 assumido pela Prefeitura Municipal de São Paulo (PMSP) través da Secretaria de Infraestrutura Urbana e Obras- SIURB. O Estudo de Impacto Ambiental e Relatório de Impacto Ambiental (EIA/ RIMA) ${ }^{21}$ referente à obra, apresenta os estudos técnicos baseados nos estudos gerais de macrodrenagem urbana do território.

Esse mesmo relatório expõe um estudo histórico fundamentado em informações jornalísticas num período de 40 anos que resultou num cronograma de ocorrência de inundações, enchentes, alagamentos ou outros problemas relacionados à infraestrutura de drenagem existente na bacia Hidrográfica do Rio Tremembé/ Ribeirão Piqueri. ${ }^{22}$

De acordo com Secretaria Municipal de Infraestrutura Urbana e Obras (SIURB), os dados foram levantados a partir de dezembro de 1969 até os dias atuais utilizando como fonte principal o Jornal "Folha de São Paulo". Além do cronograma completo, o relatório também disponibiliza um quadro- resumo a partir de uma seleção das reportagens com o tema de ocorrência e suas consequências (Tabela 3).

\footnotetext{
${ }^{20}$ Para a realização das "Obras para Controle de Inundações da Bacia do Córrego Tremembé" a Prefeitura Municipal de São Paulo (PMSP) firmou compromisso com o Governo Federal, através do Ministério das Cidades em junho/ 2014, de investimento através do PAC 2- Programa de Aceleração do crescimento, denominado PAC de drenagem.

${ }^{21}$ Relatório divulgado pela Secretaria de Verde e Meio Ambiente da Prefeitura da Cidade de São Paulo disponível em: https://www.prefeitura.sp.gov.br/cidade/secretarias/upload/meio_ambiente/arquivos/TRE_EIA.p df $>$. Acesso em 12 de dez de 2019.

22 O Ministério das Cidades/IPT (2007) esclarece a diferença entre esses eventos naturais. Define inundação como "o transbordamento das águas de um curso d'água, atingindo a planície de inundação ou área de várzea"; enchentes ou cheias como "a elevação do nível d'água no canal de drenagem devido ao aumento da vazão, atingindo a cota máxima do canal, porém, sem extravasar" e alagamento como "um acúmulo momentâneo de águas em determinados locais por deficiência no sistema de drenagem" (TOMINAGA, L.K et al., 2015, p. 42).
} 


\begin{tabular}{|c|c|c|c|c|c|c|c|}
\hline $\mathbf{N}^{\circ}$ & Ano & Mês & Dia & Caderno & Pág. & Tipo de ocorrência & Local \\
\hline 34 & 1975 & 1 & 18 & $\begin{array}{l}\text { Folha de São } \\
\text { Paulo }\end{array}$ & 1 & ENCHENTE MATOU DOIS & $\begin{array}{l}\text { AV. MARIA AMÁLIA } \\
\text { LOPES DE AZEVEDO }\end{array}$ \\
\hline 26 & 1978 & 12 & 28 & $\begin{array}{l}\text { Folha de São } \\
\text { Paulo }\end{array}$ & 1 & $\begin{array}{l}\text { APÓS A ENCHENTE LAMA } \\
\text { E DESABRIGO }\end{array}$ & $\begin{array}{l}\text { REGIÃO DA } \\
\text { FAZENDINHA }\end{array}$ \\
\hline 39 & 1978 & 12 & 28 & $\begin{array}{l}\text { Folha de São } \\
\text { Paulo C }\end{array}$ & 14 & $\begin{array}{l}\text { NA CIDADE, NOVAMENTE } \\
\text { A ROTINA DAS } \\
\text { ENCHENTES }\end{array}$ & $\begin{array}{l}\text { VILA SÃO JOSÉ E } \\
\text { FAZENDINHA }\end{array}$ \\
\hline 6 & 1981 & 1 & 11 & Caderno Local & 17 & $\begin{array}{l}\text { INUNDAÇÕES NA ZONA } \\
\text { NORTE }\end{array}$ & $\begin{array}{l}\text { AV. MARIA AMÁLIA } \\
\text { LOPES DE } \\
\text { AZEVEDO-V.ZILDA }\end{array}$ \\
\hline 22 & 1982 & 3 & 13 & $\begin{array}{l}\text { Folha de } \\
\text { SP.A- } 13 \\
\text { Cidades }\end{array}$ & 13 & $\begin{array}{l}\text { CHUVAS ALAGAM } \\
\text { BAIRROS DA ZONA NORTE }\end{array}$ & $\begin{array}{l}\text { R.JOSÉ BERGAMINI } \\
\text { NO JD. TREMEMBÉ }\end{array}$ \\
\hline 10 & 1989 & 2 & 9 & $\begin{array}{l}\text { Folha de } \\
\text { SP.Cidades }\end{array}$ & 3 & $\begin{array}{l}\text { CHUVAS CAUSAM } \\
\text { ENCHENTES NA ZONA } \\
\text { NORTE }\end{array}$ & $\begin{array}{l}\text { RUA GENARO } \\
\text { MARINO- } \\
\text { JD.TREMEMBÉ }\end{array}$ \\
\hline 15 & 2005 & 10 & 19 & $\begin{array}{l}\text { Folha de SP. } \\
\text { Cotidiano }\end{array}$ & 2 & $\begin{array}{l}\text { MORADOR PEDE QUE O } \\
\text { CÓRREGO SEJA } \\
\text { CANALIZADO }\end{array}$ & $\begin{array}{l}\text { RUA CANATIAR } \\
\text { TREMEMBÉ }\end{array}$ \\
\hline 16 & 2006 & 3 & 21 & $\begin{array}{l}\text { Folha de } \\
\text { SP.Cotidiano }\end{array}$ & 7 & $\begin{array}{l}\text { TEMPORAL DEIXA VIAS } \\
\text { DEBAIXO D'ÁGUA }\end{array}$ & $\begin{array}{l}\text { RUA CONCHILIA E } \\
\text { CORRENTINO }\end{array}$ \\
\hline 17 & 2007 & 10 & 23 & $\begin{array}{l}\text { Folha de SP. } \\
\text { Cotidiano }\end{array}$ & 5 & $\begin{array}{l}\text { TEMPORAL MATA DUAS } \\
\text { CRIANÇAS E UMA } \\
\text { MULHER }\end{array}$ & RUA CONCHIGLIA \\
\hline 18 & 2008 & 2 & 25 & $\begin{array}{l}\text { Folha de SP } \\
\text { Cotidiano }\end{array}$ & 6 & $\begin{array}{l}\text { NATÁLIA, 14, MORRE EM } \\
\text { DESLIZAMENTO DE TERRA }\end{array}$ & RUA CALANDRA \\
\hline
\end{tabular}

Tabela 3- Resumo das reportagens que apontam transtornos relacionados à drenagem em locais da Bacia Hidrográfica do Tremembé. Fonte: Secretaria de Infraestrutura Urbana e Obras da Prefeitura de São Paulo- EIA/ RIMA (2014).

A partir desta pesquisa, o Estudo de Impacto Ambiental e Relatório de Impacto Ambiental (EIA/ RIMA) concluiu que a bacia apresenta há tempos problemas relacionados com a drenagem urbana e que, mesmo após as notícias referentes à manutenção e limpeza dos córregos, as ocorrências persistiram. Ressalta-se no documento que o acúmulo de resíduos nos canais também contribui para os transtornos relativos ao escoamento na região, uma vez que esses sedimentos, muitas vezes também instalados nas margens, provocam a redução da seção fluvial dos cursos d'água. Nessa direção e a partir dos cálculos que comprovaram a incapacidade da calha do Rio Tremembé em vista à vazão requerida, o estudo afirma ser necessária a implantação do empreendimento hoje já em construção para a minimização desses eventos. 


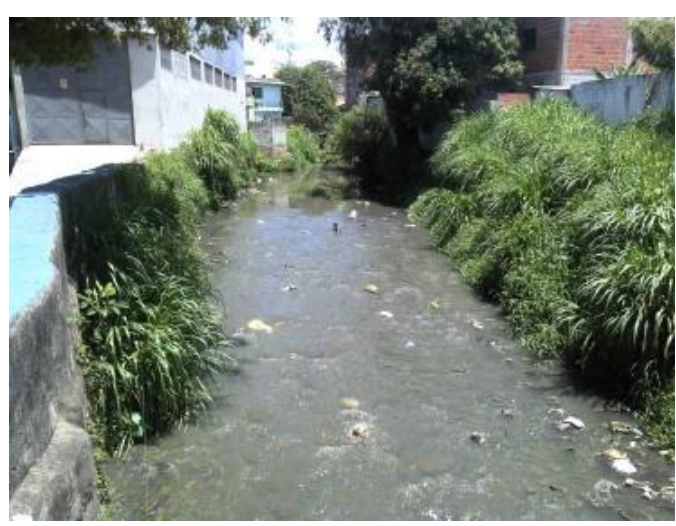

Figura 104- Trecho do Rio Tremembé com Figura 105- Trecho do Rio Tremembé com acúmulo de resíduos. Fonte: SIURB- EIA/ destaque para o confinamento da calha e RIMA (2014)

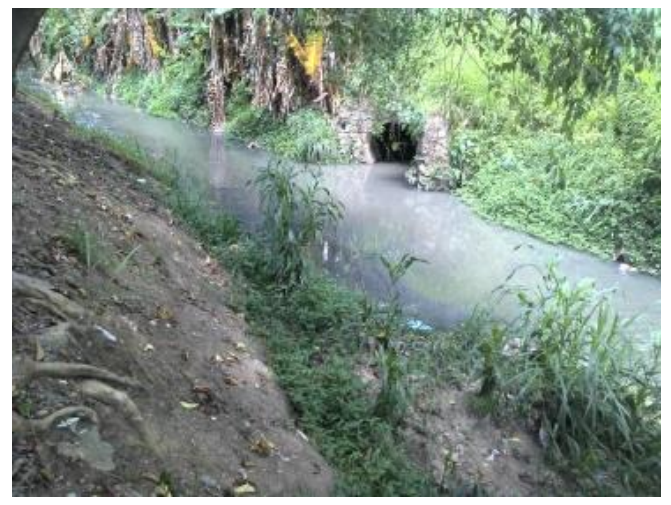

Figura 106- Rio Tremembé com galeria que lança efluentes no canal e indícios de assoreamento da margem oposta. Fonte: SIURB- EIA/ RIMA (2014).

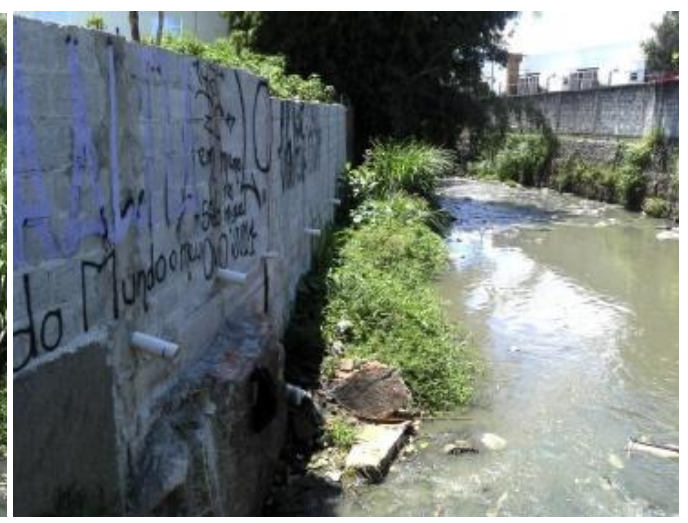
impermeabilização das encostas. Fonte: SIURB- EIA/ RIMA (2014)

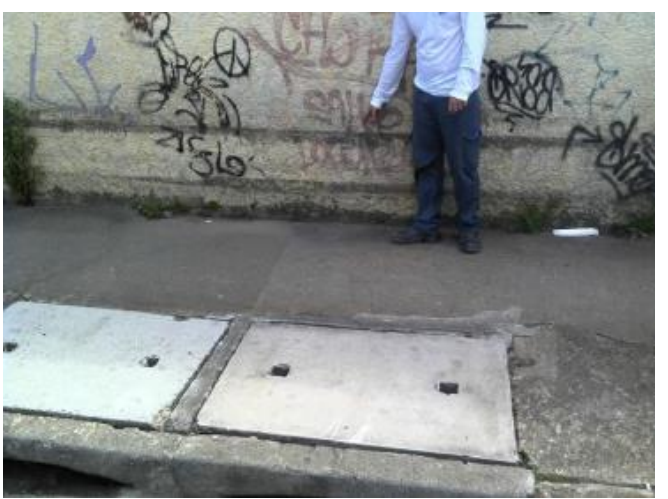

Figura 107- Marca d’água na parede como indício da ineficiência das infraestruturas de drenagem. Fonte: Fonte: Secretaria de Infraestrutura Urbana e Obras da Prefeitura de São Paulo- EIA/ RIMA (2014).

A obra, que teve início no ano de 2011 e tem previsão de conclusão em 2020, envolve a construção de galerias de concreto em sete trechos, alguns deles envolvendo o córrego do horto e o córrego esmaga sapo bem como canalização de trechos do Rio Tremembé já concluídas nos trechos entre as ruas Imbiras e Casuarinas e entre a Avenida Coronel Sezefredo Fagundes e a Rua Rodolfo Cavinato, totalizando 700 metros de canalização (SIURB, 2019). Além disso, o empreendimento envolve a ativação de 6 (seis) reservatórios de detenção ${ }^{23}$ que estão sendo distribuídos ao longo da bacia hidrográfica com a capacidade para

\footnotetext{
${ }^{23} \mathrm{~A}$ diferença entre reservatório de detenção e retenção é que o primeiro implica na liberação da água acumulada (BONZI, 2015).
} 
armazenar um volume total de $116.000 \mathrm{~m}^{3}$ de água, bem como com a retificação e/ou aumento da calha ao longo dos córregos pertencentes à mesma bacia.

Conhecidos popularmente como "piscinões", os reservatórios de detenção começaram a ser construídos no Brasil nas últimas décadas do século XX e atuam como um complemento do sistema convencional das águas pluviais. A sua função consiste em armazenar o volume de água gerado nas bacias densamente urbanizadas por um tempo determinado e liberá-las após um período (PELLEGRINO, 2017). A seguir, visualiza-se o mapa com possível localização dos reservatórios de detenção na Bacia do Hidrográfica do Tremembé e o quadro com os respectivos volumes de capacidade.

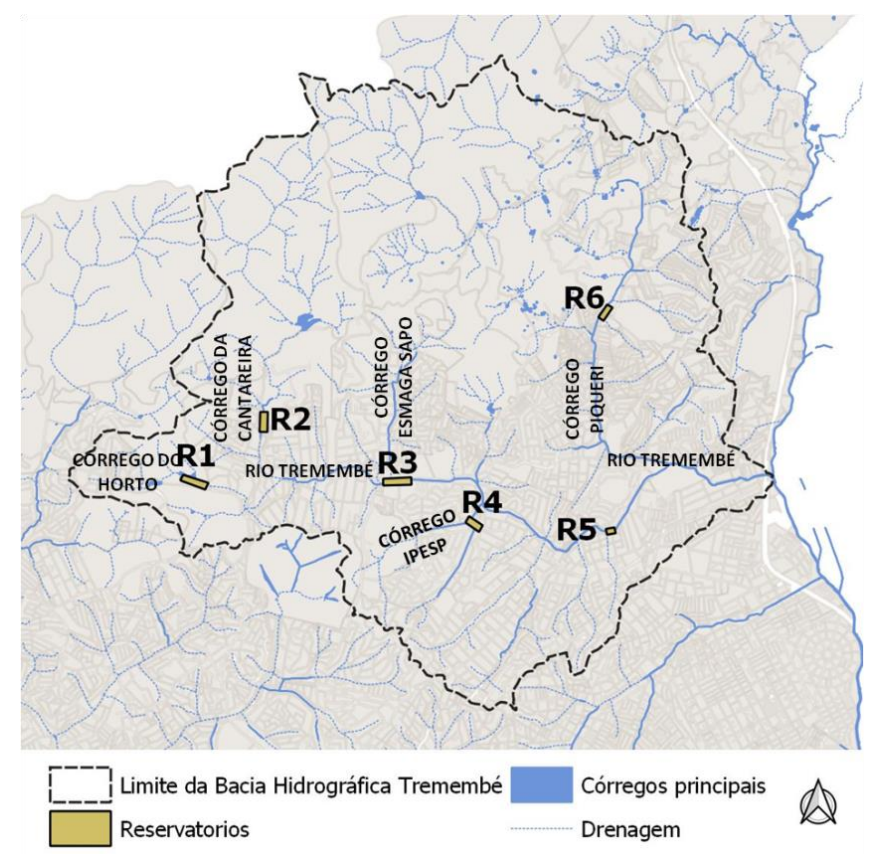

Figura 108- Localização dos reservatórios de detenção propostos na Bacia Hidrográfica do Tremembé. Fonte: SIURB- EIA/ RIMA (2014) com adaptações da autora (2019)

\begin{tabular}{|c|ccc|}
\hline RESERVATÓRIO & VOLUME ESTIMADO $\left(\mathrm{m}^{3}\right)$ & LOCALIZAÇÃO & SUB-BACIA \\
\hline \hline R1 & 15.000 & Lagos Existentes no Horto Floretal & HORTO \\
\hline R2 & 20.000 & Rua São Cleto (a montante do asilo) & CANTAREIRA \\
\hline R3 & 18.000 & Av. Maria Amália Lopes de Azevedo & TREMEMBÉ \\
\hline R4 & 15.000 & Rua Manuel Gaya (estac da Dicico) & CÓRREGO IPESP \\
\hline R5 & 12.000 & Rua Florinda Barbosa & TREMEMBÉ \\
\hline R6 & 51.000 & Av. Ushikichi Kamiya & PIQUERI \\
\hline
\end{tabular}

Tabela 4- Localização e volumes dos reservatórios propostos.

Fonte: Infraestrutura Urbana e Obras da Prefeitura de São Paulo- EIA/ RIMA (2014). 
Dentre esses reservatórios, verificou-se que apenas os reservatórios R1 (Lagos Existentes no Horto Florestal) e R3 (Rua Maria Amália Lopes de Azevedo) estão em trabalho de execução. O reservatório R1, localizado dentro do Horto Florestal, antigo Lago das Capivaras, reforçará o controle das cheias em importantes vias da região como as ruas Vicente de Carvalho e Estrada da Chapada (figuras 109 e 110). As obras do reservatório R3 foram iniciadas em junho de 2018 e, atualmente está na etapa dos serviços de escavação e concretagem (figuras 111 a 114).

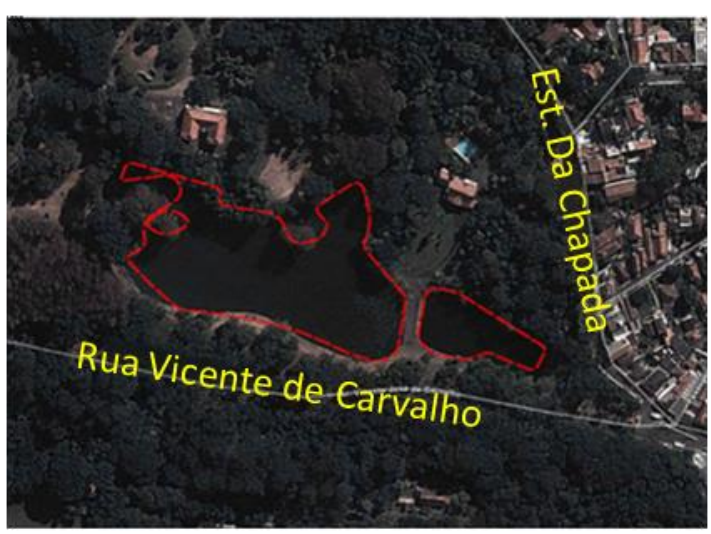

Figura 109- Localização prevista para a implantação do reservatório de detenção R1 no lago do Parque Estadual Horto Florestal. Fonte: SIURB- EIA/ RIMA (2014).

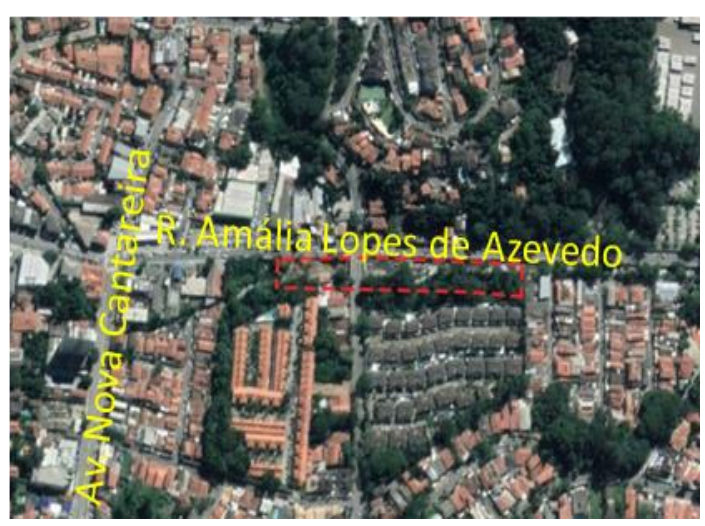

Figura 111- Localização prevista para a implantação do reservatório de detenção R3 na Rua Amália Lopes de Azevedo. Fonte: Infraestrutura Urbana e Obras da Prefeitura de São Paulo- EIA/ RIMA (2014).

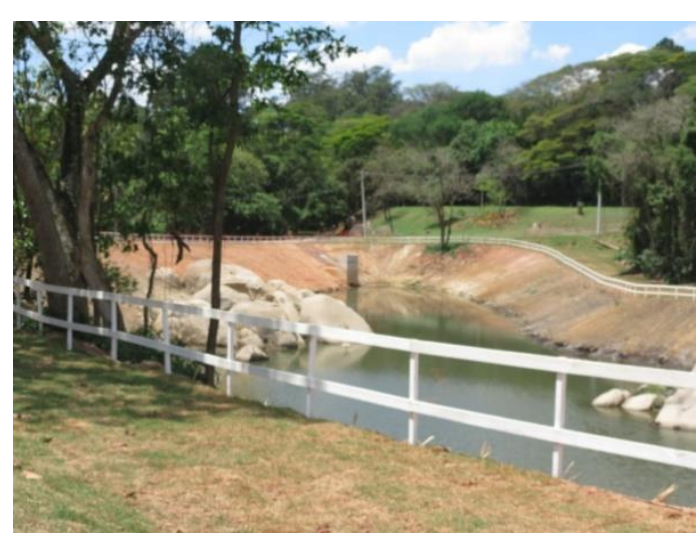

Figura 110- Reservatório de detenção R1 já construído no lago do Parque Estadual Horto Florestal. Fonte: Produção da autora (2019).

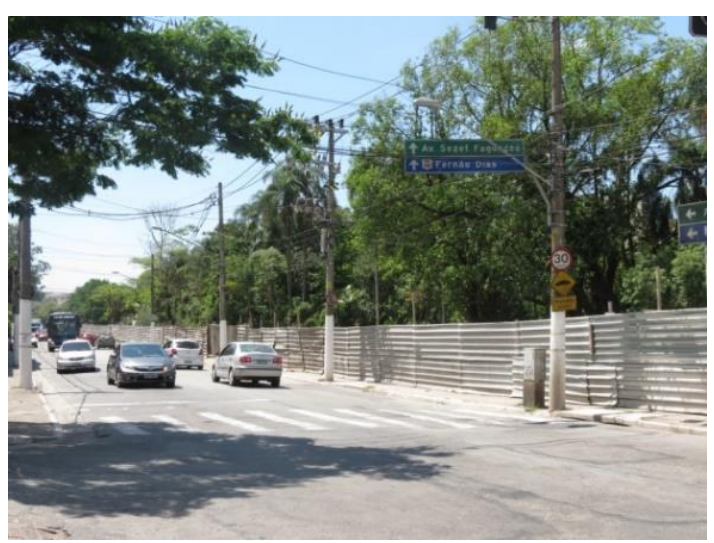

Figura 112- Local onde ocorrem as obras do reservatório detenção R3 a partir da Av. Amália Lopes de Azevedo. Fonte: Produção da autora (2019). 


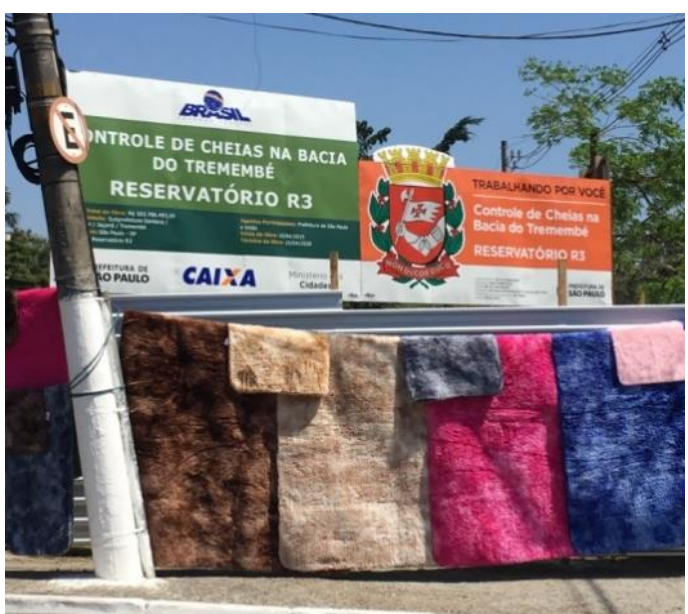

Figura 113- Obras do reservatório de detenção R3 na Rua Amália Lopes de Azevedo. Fonte: Produção da autora (2019).

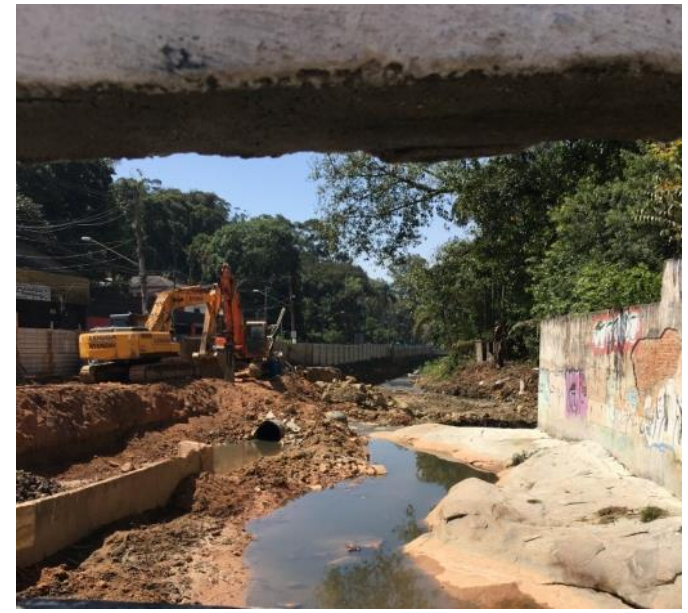

Figura 114- Obras do reservatório de detenção R3 na Rua Amália Lopes de Azevedo. Fonte: Produção da autora (2019).

As localizações dos demais reservatórios previstos constam nas próximas figuras (ver figuras de 115 a 123). A SIURB informou no mês de maio de 2019 que a realização das outras ações previstas do empreendimento despenderá da finalização dos processos de desapropriação. Neste quadro, destaca-se a área destinada à construção do reservatório R6 que antes se referia à um terreno desocupado e que hoje se está bastante modificado, tomado por vielas e ocupações irregulares. As figuras 121 e 122 oferecem um comparativo entre os anos de 2016 e 2019- período em que se deu o avanço da urbanização na região.

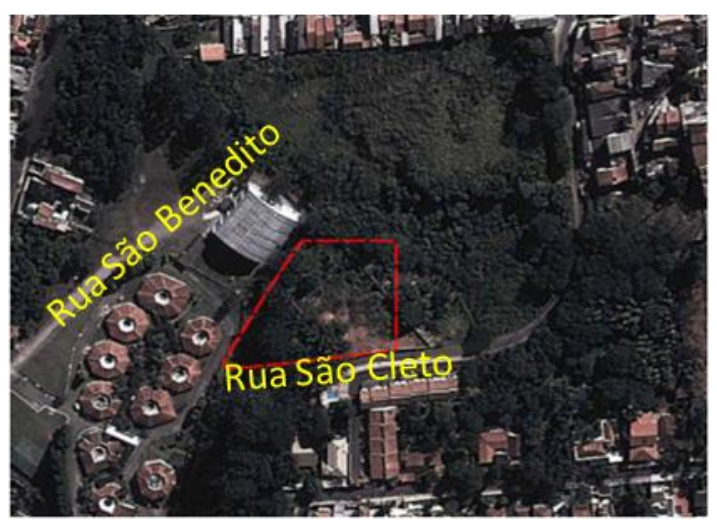

Figura 115- Localização prevista para a implantação do reservatório de detenção R2 na Rua São Cleto. Fonte: SIURB- EIA/ RIMA (2014).

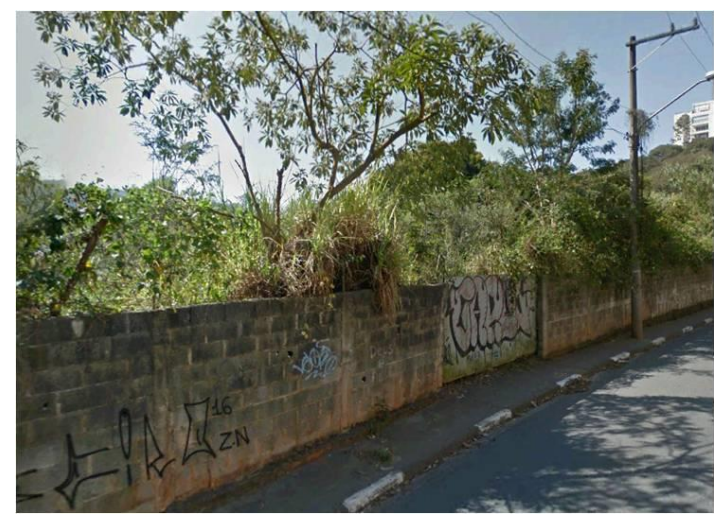

Figura 116- Vista do local previsto para a implantação do reservatório de detenção R2 a partir da Rua São Cleto. Fonte: Google Earth (2019). 


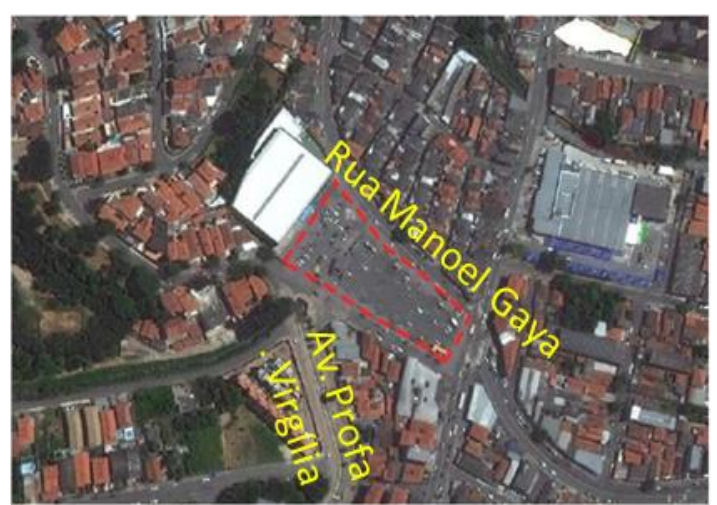

Figura 117- Localização prevista para a implantação do reservatório de detenção R4 próximo da Rua Manoel Gaya e Av. Professora Vigília Rodrigues Alves de Carvalho Pinto. Fonte: SIURB- EIA/ RIMA (2014).

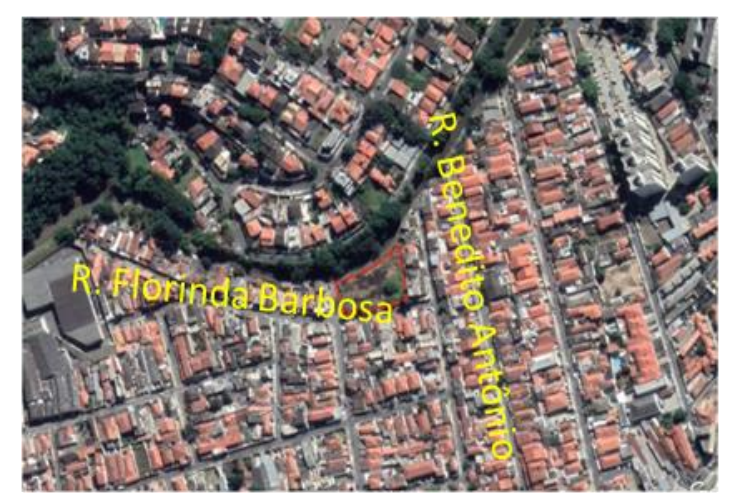

Figura 119- Vista aérea no ano de 2019: localização prevista para a implantação do reservatório de detenção R5 na Florinda Barbosa. Fonte: Google Earth (2019).

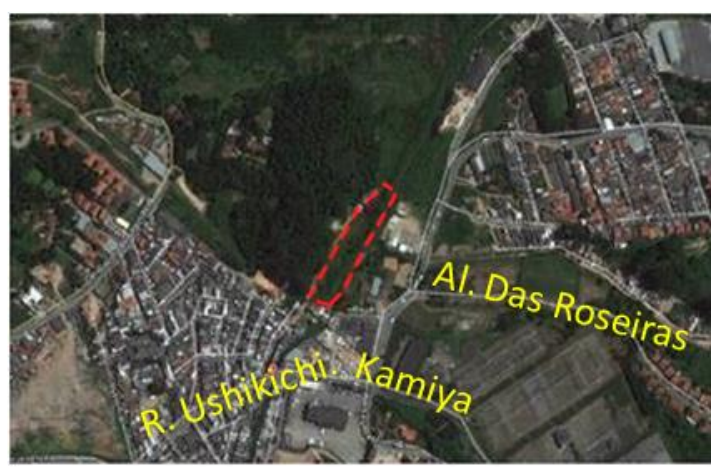

Figura 121- Vista aérea no ano de 2016: localização prevista para a implantação do reservatório de detenção R6. Fonte: Google Earth (2017).

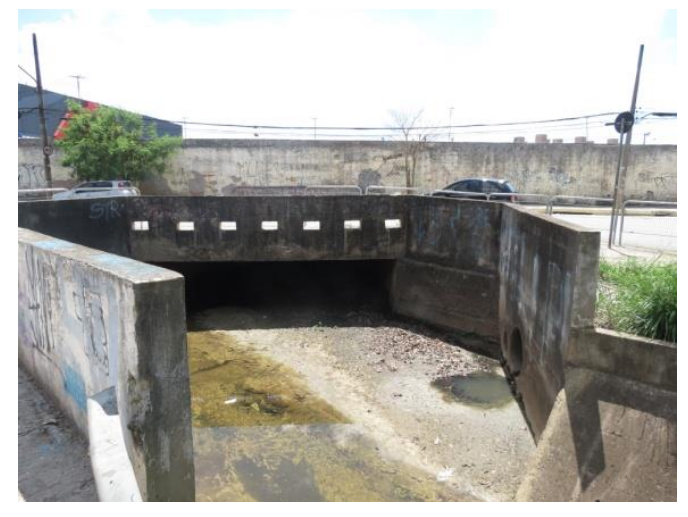

Figura 118- No primeiro plano galeria de concreto já construída no Córrego IPESP. No segundo plano, muro do estacionamento onde está previsto a implantação do reservatório de detenção R4. Fonte: Laís Leite (2019).

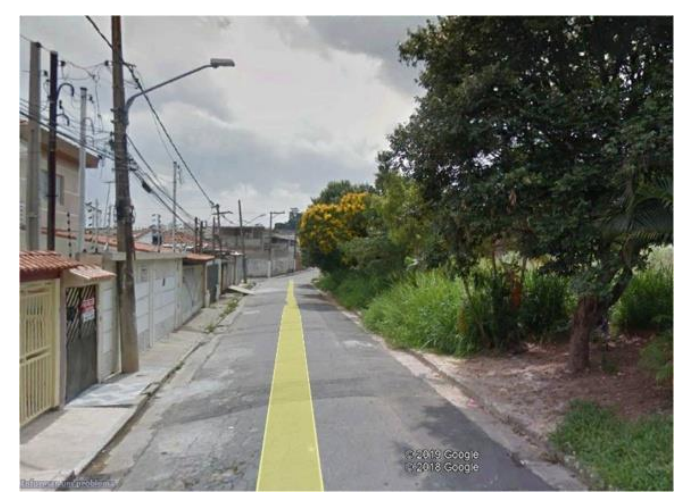

Figura 120- Vista a partir da Rua Florinda Barbosa do terreno onde está previsto a implantação do reservatório de detenção R5. Fonte: Laís Leite (2019).

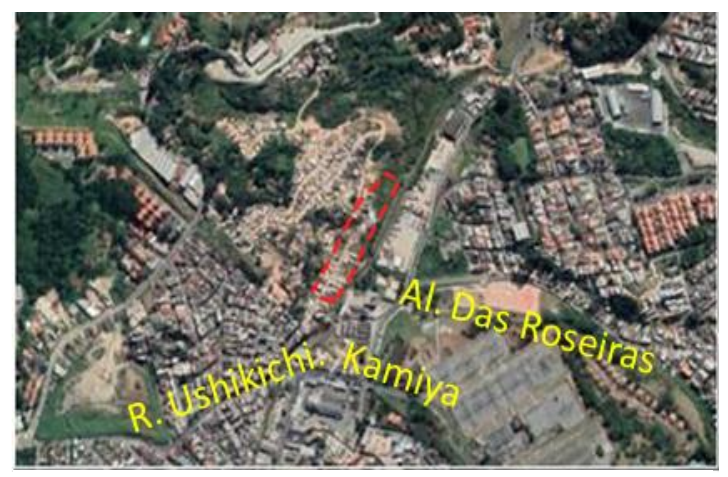

Figura 122- Vista aérea no ano de 2019: localização prevista para a implantação do reservatório de detenção R6. Fonte: Google Earth (2019). 


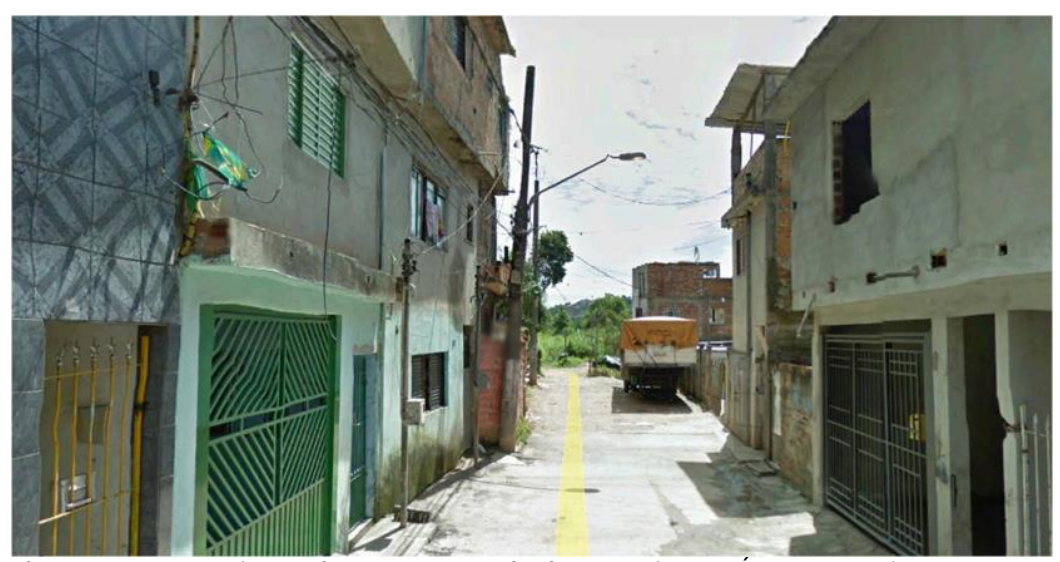

Figura 123- Vista da Rua Natal de Queiroz: Área prevista para a implantação do reservatório de detenção R6. Fonte: Google Earth (2019).

\subsubsection{OS RESERVATÓRIOS DE DETENÇÃO E SEUS LEGADOS PARA PAISAGEM}

De acordo com a SMDU (2012), estão previstos a implementação de mais de 134 piscinões ao longo da Bacia do Tietê até o ano de $2020 \mathrm{com}$ a finalidade de pelo menos amenizar os efeitos críticos relativos à drenagem da RMSP. O emprego desse tipo de tipologia passou a ser recorrente tendo em vista a sua capacidade de reduzir as áreas alagadas após ocorrências de chuvas e temporais amenizando os transtornos que impactam a população como acidentes, perdas materiais e congestionamentos (MOURA, 2017). Constituídos por estruturas rígidas implantadas após o processo de urbanização, são empregados com a função de dar vazão à drenagem de um território o qual foi baseado na impermeabilização excessiva e ocupação das suas várzeas. Conforme explica o

(...) Implantar reservatórios de amortecimento de cheias que permitem controlar as descargas e retardar a chegada dos picos de vazão para jusante. Conceitualmente, os reservatórios de contenção de cheias atuam no sentido de compensar os citados aspectos negativos da urbanização, com o objetivo de resgatar ou devolver, mesmo que parcialmente, as condições naturais equivalentes de uma determinada bacia hidrográfica" (PDMAT1,1999). 
Com o principal objetivo de controlar o quantitativo das enchentes, esse tipo de reservatório se destaca pela grande capacidade de retenção das águas pluviais e consequente redução do pico de uma chuva com potencial para causar inundações. Sua composição básica consiste em um elemento para o armazenamento de águas advindas do escoamento associado à uma estrutura hidráulica de controle fixa e sem possibilidade de comando. Sendo assim, apesar de atuarem como um redutor dos transtornos hidráulicos, esse tipo de reservatório apenas contém a água da chuva por um determinado tempo e realiza o seu descarte posteriormente (ABRIL, 2017).

Apesar de suas vantagens no que se refere à diminuição dos transtornos hidráulicos, é preciso ressaltar que os piscinões têm se revelado uma estratégia ineficaz com efeitos negativos no campo das dinâmicas ambientais e no âmbito social urbano (MOURA, 2017).

No processo de armazenamento da água, a poluição difusa oriunda da bacia hidrográfica também é direcionada para essas construções, o que inclui lixo e resíduos originados pelo processo de assoreamento, esgoto doméstico não tratado e outras partículas existentes no solo urbano. Esses dispositivos hidráulicos acabam se constituindo como verdadeiros focos de riscos sanitários e ambientais, já que a dificuldade da limpeza de suas áreas livres também põe em xeque a qualidade da água armazenada (ABRIL, 2017). Assim, uma rede de drenagem constituída por reservatórios demanda limpeza e manutenção periódica desses equipamentos de maneira a não gerar problemas como obstrução das suas grades e bombas ou aspecto desagradável e mau cheiro.

O impacto dessas estruturas reflete também no meio social do território, já que resultam na formação de espaço público que não oferece usos produtivos para a população do entorno. Dessa maneira, o vazio urbano cumpre apenas o objetivo de armazenamento da água, sem agregar nenhum valor ao seu redor (COACHMAN; FRANCO, 2012 apud ABRIL, 2017.

De acordo com Ferguson (2002), os dispositivos de detenção também se mostram ineficientes no que se refere ao tratamento da qualidade da água e no recarregamento das águas subterrâneas do território. O autor ressalta que, 
quando vegetadas, além de serem capazes de realizar a filtragem das impurezas, as bacias hidrográficas conseguem reter mais da metade da precipitação anual pelo processo de evapotranspiração do solo e das plantas, alimentando o lençol freático e amenizando as inundações dos cursos d'água.

Nesse sentido, as estruturas hidráulicas rígidas dos piscinões, tidas atualmente como a principal solução para os problemas hidráulicos presentes nas bacias urbanizadas, deveriam dar mais espaço aos espaços vegetados e suas funções potenciais oferecidas pelos sistemas naturalizados que inclui os efeitos das águas através da vegetação, solo e subsolo. Estes serviços ambientais deveriam ser admitidos enquanto parte da rede de infraestrutura das cidades e como um importante recurso para os ecossistemas e pessoas (FERGUSON, 2002).

\subsubsection{OBRA DO TRECHO NORTE DO RODOANEL MÁRIO}

\section{COVAS}

O intitulado Rodoanel Mário Covas ou simplesmente conhecido como "Rodoanel" trata-se de um anel rodoviário com aproximadamente de 180 quilômetros de extensão que circunda a região central da Grande São Paulo, interligando as rodovias que chegam à capital: Bandeirantes (SP-348), Anhanguera (SP-330), Castello Branco (SP-280), Raposo Tavares (SP-270), Régis Bittencourt (BR-116), Anchieta (SP-150), Imigrantes (SP-160), Ayrton Senna (SP70), Fernão Dias (BR-381) e Dutra (BR-116/SP-60)(DERSA, 2010).

Esta grande rodovia é dividida em 04 (quatro) trechos denominados Norte, Sul, Leste e Oeste. O trecho oeste teve sua construção iniciada no ano de 1998 com inauguração no ano de 2002, o trecho sul foi liberado no ano de 2010 e já no ano de 2014, foi finalizado o trecho leste. O trecho norte, por sua vez, tinha previsão de entrega no ano de 2019 mas ainda está em construção com conclusão prevista somente para o ano de 2022 (Jornal Folha de São Paulo,2019). 


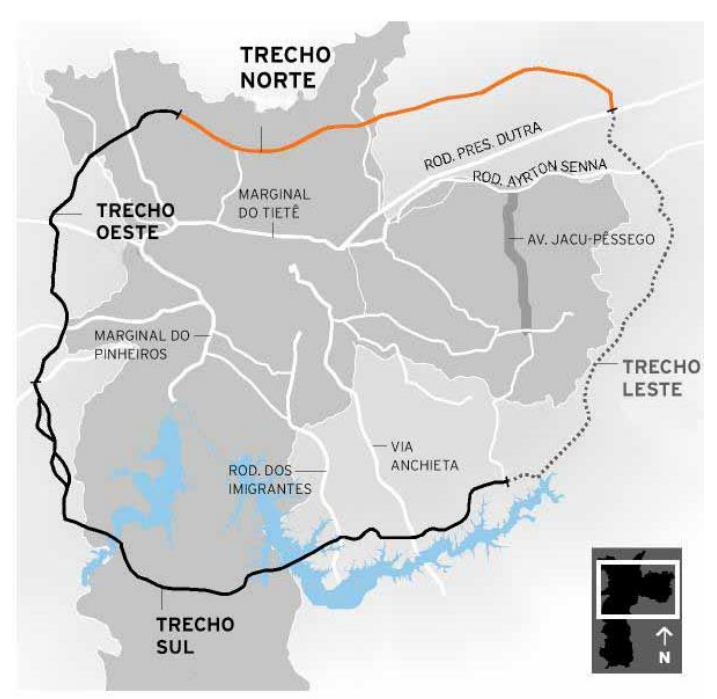

Figura 124- Trechos do Rodoanel Mário Covas que circundam a Grande São Paulo com destaque em laranja para o trecho norte ainda em construção. Fonte: Estudo de Impacto Ambiental do Trecho Norte do Rodoanel.

A construção do trecho Norte do Rodoanel Mário Covas, que está sendo gerenciada pela Dersa (empresa de economia mista ligada ao Governo de São Paulo), contará com 43,8 km de extensão e ligará o trecho Oeste, a partir da Avenida Raimundo Pereira Guimarães, ao trecho Leste, na intercessão com a rodovia Presidente Dutra (BR-116). O trecho Norte também possibilitará acesso à rodovia Fernão Dias (BR-381) e pista de acesso ao Aeroporto Internacional Franco Montoro em Guarulhos. O seu traçado conta com vários trechos em obras de arte especiais (OAE), incluindo sete túneis além de 111 obras de arte estruturais englobando pontes e viadutos (Estado de São Paulo, 2013). 


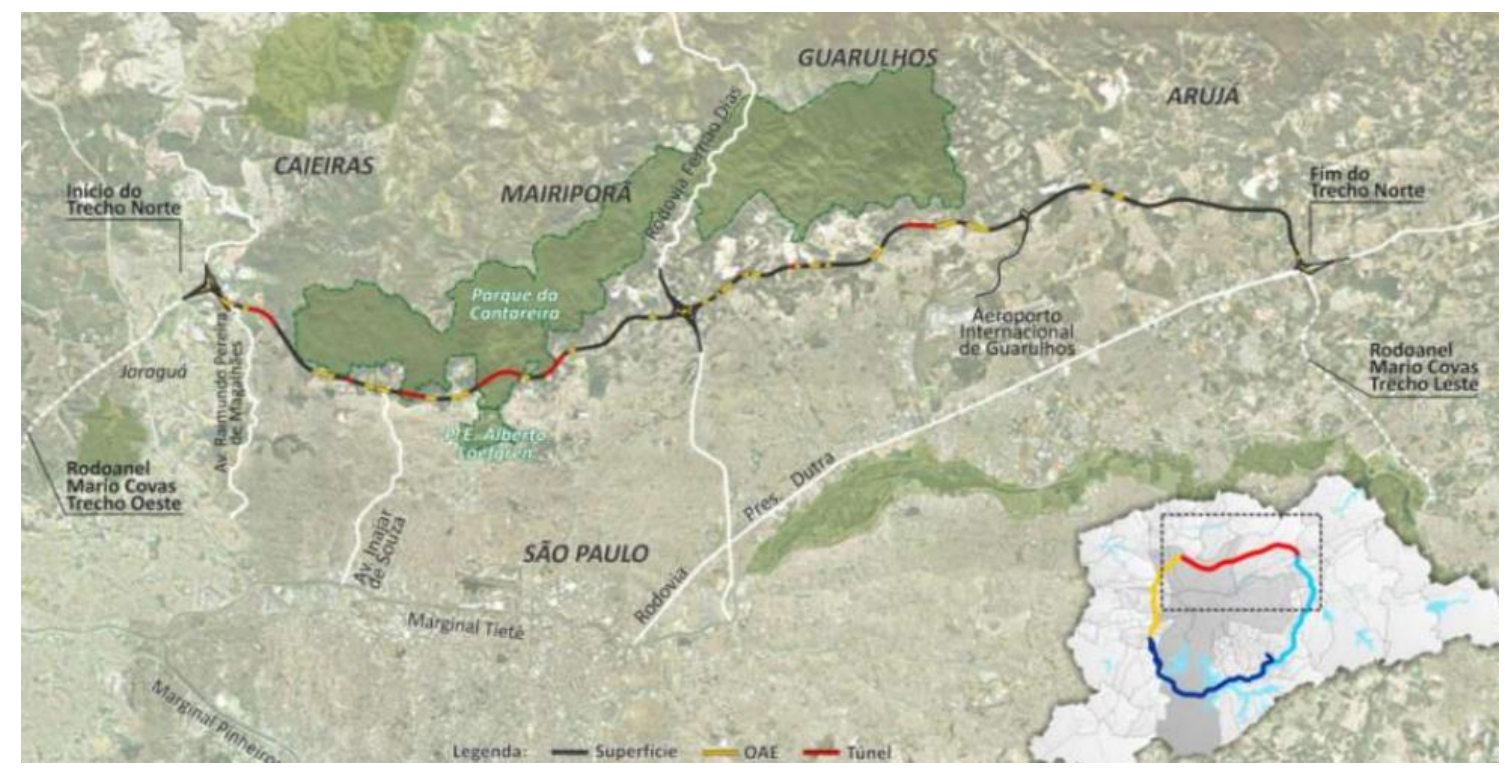

Figura 125- Rodoanel Mário Covas- Trecho Norte. Fonte: Estado de São Paulo (2013).

Sua extensão apresenta grande proximidade com o Parque Estadual da Cantareira e se instalará na área referente à Zona de Amortecimento desta unidade de conservação. Diante disto, o trecho Norte do Rodoanel, juntamente com outras obras rodoviárias próximas do PEC como a Rodovia Fernão Dias (BR 381), Estrada de Santa Inês, Estrada da Roseira, Av. Coronel Sezefredo Fagundes e Av. Senador José Ermínio de Moraes podem comprometer a preservação da mata caso não sejam fiscalizadas ou planejadas com cautela. Tais construções viárias podem ser compreendidas como uma ameaça ao PEC pelo fato de estimularem o crescimento urbano, a especulação imobiliária no entorno e favorecer o acesso às suas áreas internas (SANDRE, 2017).

É importante ressaltar também que o trecho Norte do Rodoanel em execução percorrerá áreas caracterizadas pelo Plano Diretor Estratégico de São Paulo (Lei 16.050/2014) como de fragilidade ambiental. Além disso, a construção impactará pequenas propriedades rurais que adotam práticas agrícolas sustentáveis e que contribuem para preservação do maciço da Cantareira e de suas nascentes. A Fazenda Santa Maria localizada no distrito do Tremembé é um exemplo desse tipo de propriedade e que será impactada diretamente pela 
construção da rodovia. Os seus habitantes, que atuaram durante anos às práticas de plantações e colheita de alimentos na região, serão desapropriados ${ }^{24}$.

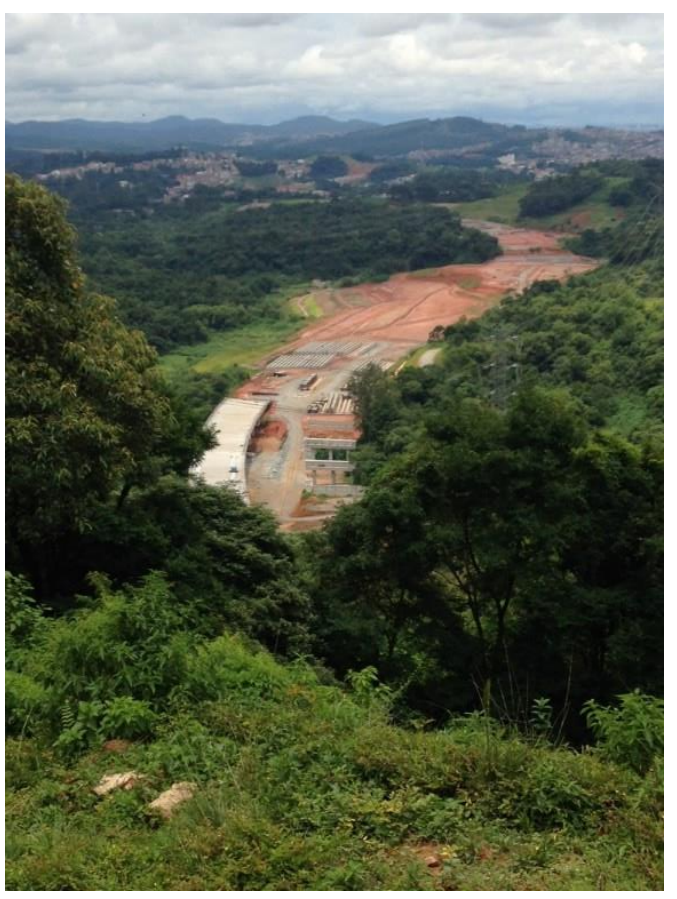

Figura 126- Construção do Trecho Norte do Rodoanel Mário Covas na região da fazenda Santa Maria no distrito Tremembé. Fonte: Conceição Aparecida Santos (2016). Disponível em: < https://www.serradacantareirahoje.com/tag/fazend a-santa-maria/>. Acesso em 07 jan. 2020.

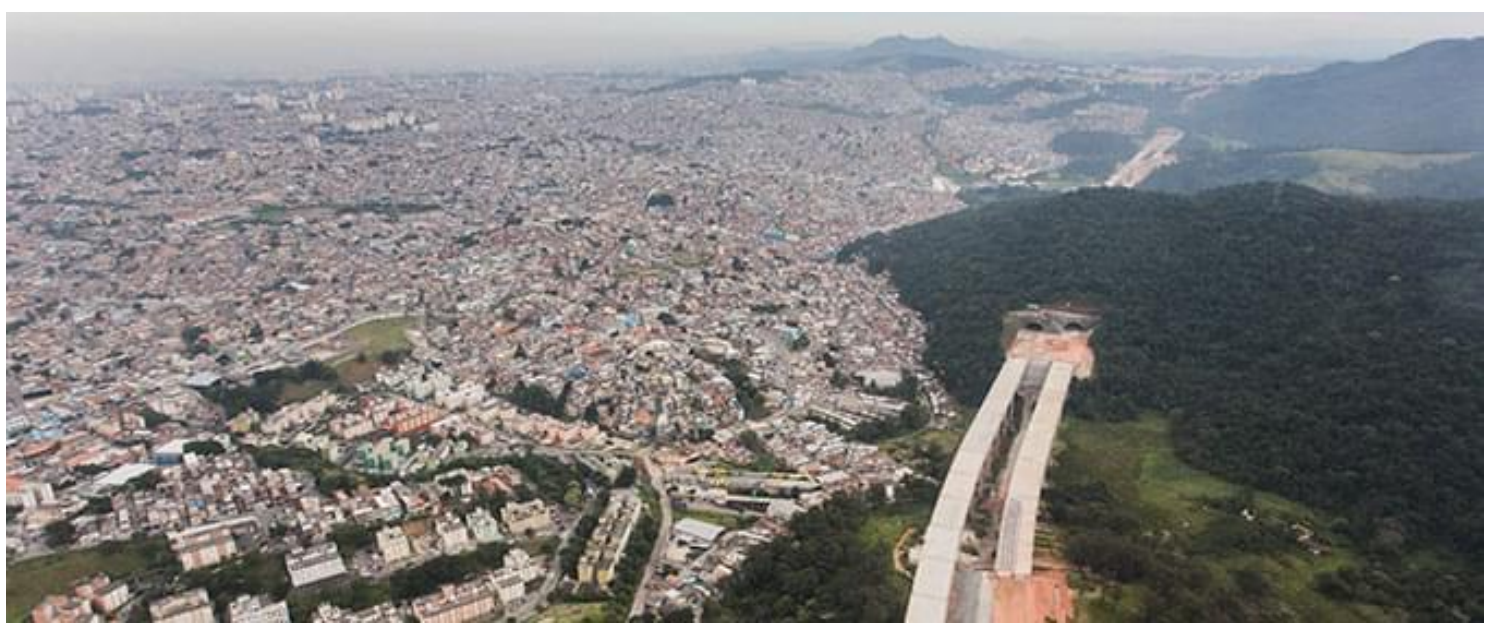

Figura 127- Construção do Trecho Norte do Rodoanel Mário Covas na região da fazenda Santa Maria no distrito Tremembé. Fonte: Conceição Aparecida Santos (2016). Disponível em: < https://www.serradacantareirahoje.com/tag/fazenda-santa-maria/>. Acesso em 07 jan. 2020.

O trecho norte do Rodoanel perpassa pela Bacia Hidrográfica do Tremembé conforme a figura 128 e encontra-se nas proximidades da buffer zone de estudo. Apesar desse tipo de obra representar uma melhoria para o trânsito das rodovias

${ }^{24}$ Disponível em: <https://www1.folha.uol.com.br/saopaulo/1131694-rodoanel-cortara-fazendade-agricultores-portugueses-na-zona-norte.shtml>. Acesso em 06 de jan. de 2020. 
na região metropolitana de São Paulo e oferecer mais eficiência ao transporte de cargas do Estado, a sua implantação pode comprometer a preservação do PEC por meio da fragmentação da mata, atropelamento de animais bem como geração ruídos, poluição, além de funcionar como uma barreira física e atrapalhar a passagem de animais (SANDRE, 2017).

Como compensação ambiental para a execução do empreendimento no trecho Norte, a Prefeitura de São Paulo exigiu a construção de 09 (nove) parques a serem implantados na Zona de Amortecimento do PEC. Dentre esses parques previstos, 05 (cinco) estão em fase de implantação, são eles: Parada de Taipas, Bispo, Bananal- Itaguaçu, Brasilândia e Bananal- Canivete, destacados em azul escuro na figura 02. Os outros 04 (quatro) parques chamados Tremembé, Santa Maria Fase I e II, Engordador, Barrocada estão destacados em verde escuro na figura 128 e ainda estão em fase de planejamento. Inicialmente, os locais funcionariam como reservas e depois poderiam ser equipados para receber 0 público. A ideia é estabelecer um cinturão verde ao longo do PEC e impedir ocupações ao longo da rodovia, como já aconteceu no trecho Oeste do rodoanel (Jornal Estadão, 2013). 


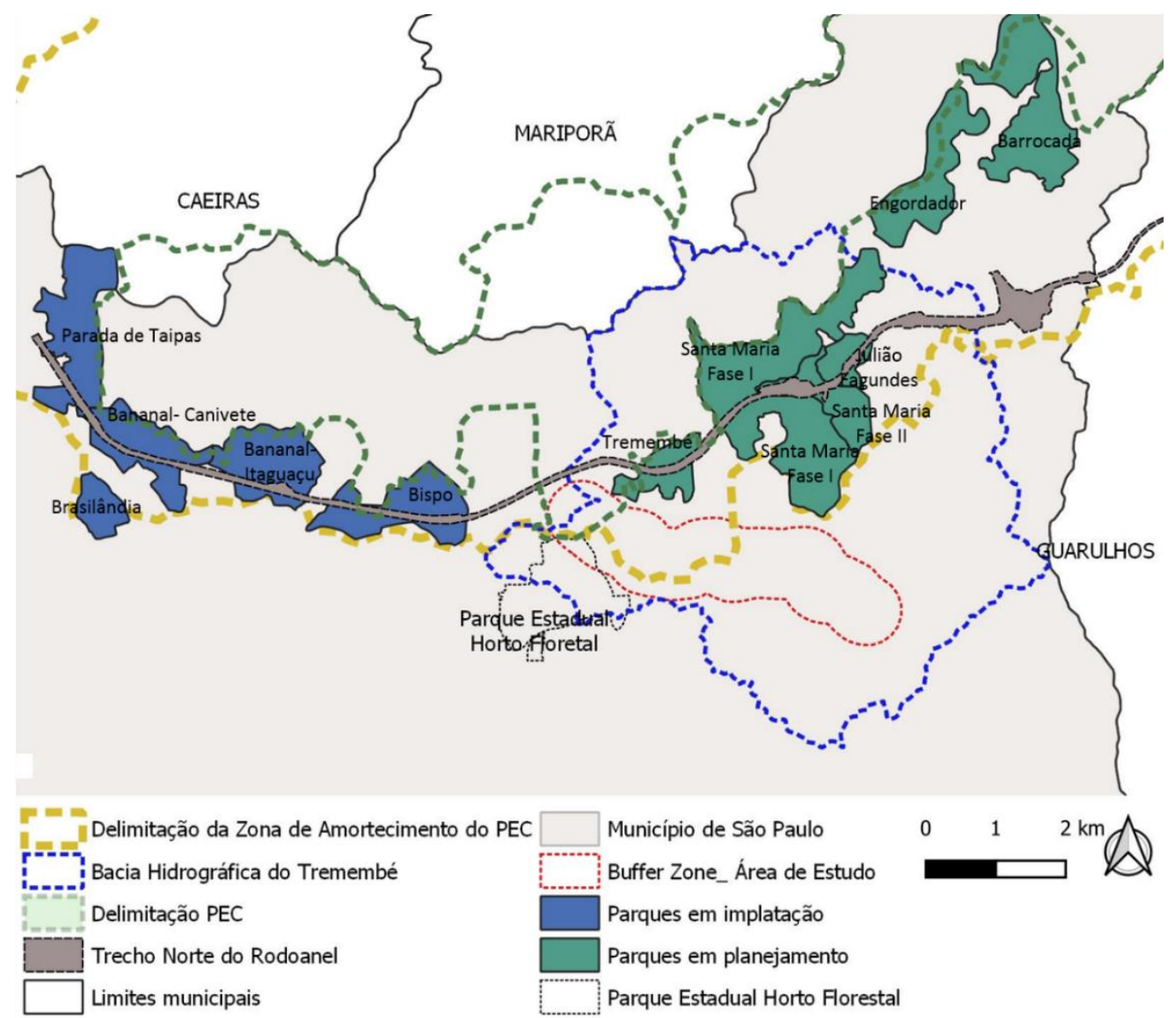

Figura 128- Mapa que indica o traçado do rodoanel na Zona de Amortecimento do PEC indicada pelo tracejado amarelo. $\mathrm{O}$ azul escuro tracejado se refere à Bacia Hidrográfica do Tremembé e o tracejado vermelho delimita a buffer zone da área de estudo. Destaque também aos parques em implantação na cor azul escuro e aos parques ainda em planejamento indicados na cor verde escuro. Fonte: Geosampa e Emplasa com adaptações da autora (2020). 
INFRAESTRUTURA VERDE APLICADA AO ALTO E MÉDIO CURSO DO RIO TREMEMBÉ III SEÇÃO | DIRETRIZES DE INFRAESTRUTURA VERDE 


\section{CAPÍTULO 5}

\section{APLICAÇÃO DA INFRAESTRUTURA VERDE}

\subsection{ZONEAMENTO URBANO AMBIENTAL}

O Zoneamento Urbano Ambiental foi desenvolvido com a finalidade de garantir que as instruções pertencentes ao plano de infraestrutura verde, descritos posteriormente, estejam de acordo com as particularidades da área de estudo. Para tanto, foi feito o cruzamento das informações pertencentes ao zoneamento ambiental com as características urbanas do local, ambas descritas no capítulo 3. Nessa direção, o mapeamento produzido aponta as particularidades presentes em cada compartimento da paisagem o que inclui suas fragilidades, capacidades e vínculos com a paisagem edificada contribuindo assim para a criação de diretrizes em sintonia com o meio ambiental e suas capacidades de suporte. Este plano de Zoneamento Urbano Ambiental considera o desenho urbano já existente do local acompanhando, assim, a conformação de suas quadras e dando atenção às modificações efetuadas como cortes, canalizações e aterros nos cursos d'água (SCHUTZER,2012). O resultado desse mapeamento pode ser observado no mapa a seguir (figura 129): 
INFRAESTRUTURA VERDE APLICADA AO ALTO E MÉDIO CURSO DO RIO TREMEMBÉ

\section{CAPÍTULO 5 | APLICAÇÃO DA INFRAESTRUTURA VERDE}

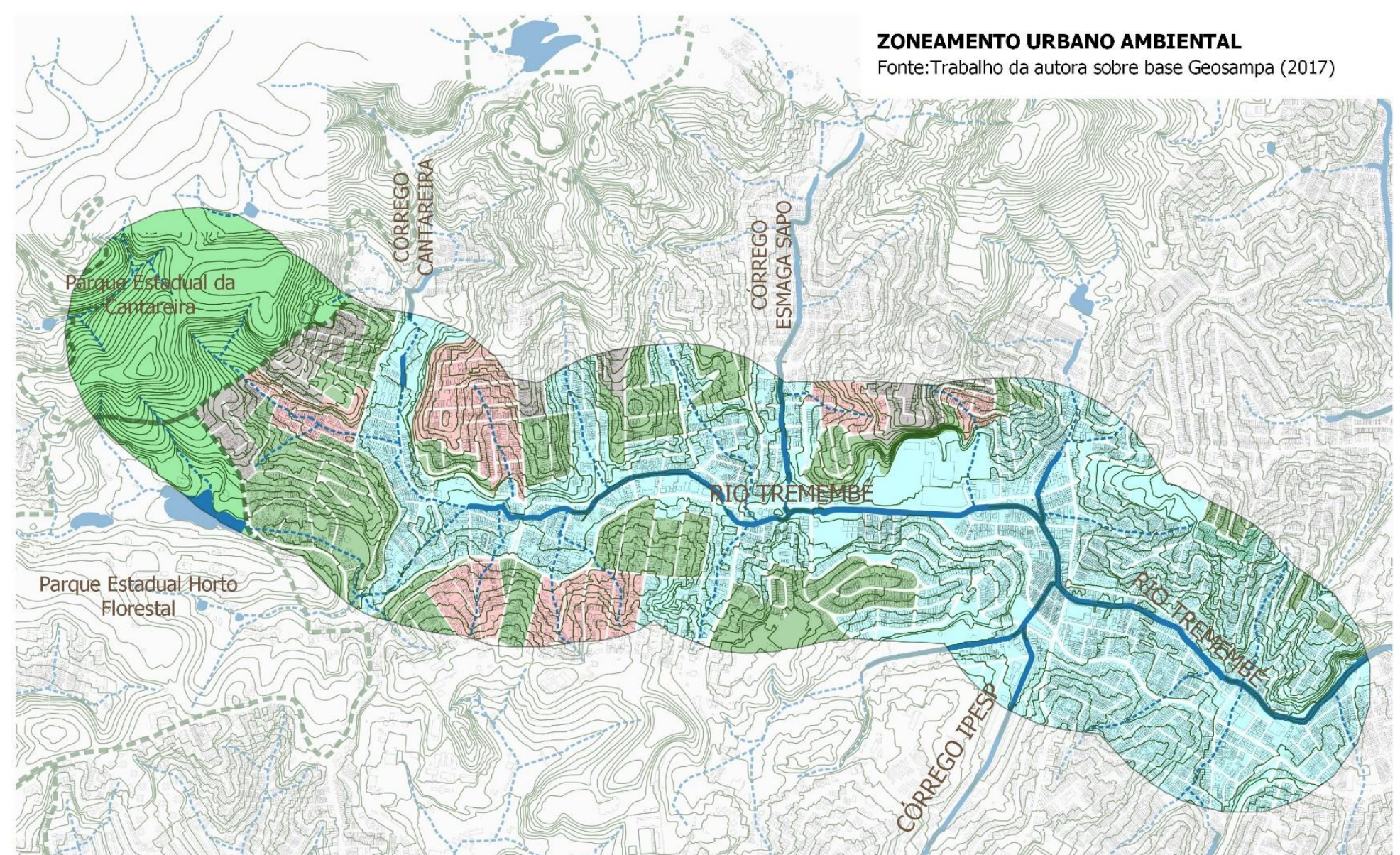

Área de Proteção- Cantareira e Horto Florestal

- Anfiteatros onde estão as nascentes

Outeiros, colinas e pequenos espigões secundários

Planícieis Aluviais

Cursos d'água a céu aberto

Cursos dágua ocultos

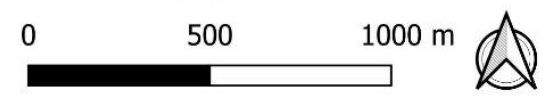

Encostas, vertentes das colinas e outeiros

Figura 129- Zoneamento urbano ambiental da área de estudo. Fonte: Trabalho da autora sobre base Geosampa. 
INFRAESTRUTURA VERDE APLICADA AO ALTO E MÉDIO CURSO DO RIO TREMEMBÉ

\section{CAPÍTULO 5 | APLICAÇÃO DA INFRAESTRUTURA VERDE}

Como indicado ao longo do capítulo 03 , o compartimento do tipo outeiros, colinas e pequenos espigões secundários deve receber 0 incentivo da permeabilidade do solo de modo a prover o abastecimento do lençol freático e das nascentes. A impermeabilização nessas regiões deve ser evitada já que o aumento do escoamento superficial resultaria em processos como poluição dos cursos d'água e processo de erosão em direção às encostas. Nesse sentido, as diretrizes de planejamento ambiental devem promover principalmente o processo de permeabilidade seja por meio da arborização ou por meio de tipologias de infraestrutura verde que colaborem para este mesmo processo.

Práticas no interior dos lotes como implementação da arborização, aumento da taxa de permeabilidade e captação das águas pluviais utilizando cisternas podem ser estimuladas por meio de programas de incentivo público. Já no espaço público pertencente à ruas e calçadas é preciso incentivar também o plantio de árvores extensivo além de tipologias de infraestrutura verde como jardins de chuva e canteiros pluviais, os quais recebem as águas do escoamento superficial com a capacidade de infiltra-las além de atuarem também na limpeza da poluição difusa das águas da chuva. Quando associados ao sistema viário, esses elementos podem conferir sinuosidade ao leito carroçável levando os automóveis a diminuírem a velocidade. Além disso, podem estar associados a praças ou parques. A biovaleta consiste em outro tipo de tipologia que pode ser aplicada nesse compartimento, visto que além de realizar a infiltração também atua no escoamento da água da chuva, conectando diferentes tipologias de infraestrutura verde, espaços públicos e sistemas convencionais de drenagem urbana. Nas calçadas, se recomenta também a implantação de pavimento drenante e implementação da arborização.

O compartimento dos anfiteatros onde se encontram as nascentes consistem em espaços de grande importância para o equilíbrio ecológico do ambiente urbano e precisam ser preservadas, não devendo ter sua ocupação incentivada. Tidos como "espaços da natureza por excelência", tais áreas apresentam como processo predominante o escoamento superficial e por esse motivo oferecem riscos de erosão, deslizamentos e assoreamento nos canais de drenagem. A utilização da vegetação nestes anfiteatros deve ser bastante 
INFRAESTRUTURA VERDE APLICADA AO ALTO E MÉDIO CURSO DO RIO TREMEMBÉ

\section{CAPÍTULO 5 | APLICAÇÃO DA INFRAESTRUTURA VERDE}

incentivada por meio da criação de espaços para lazer da população como parques e áreas de lazer terraçadas que atuem na preservação da umidade natural do local e na proteção do entorno das nascentes.

$\mathrm{Na}$ existência de uma ocupação já consolida nesses locais, é preciso assegurar o congelamento do potencial construtivo impedindo reformas e ampliações e prevendo o controle do escoamento superficial com vegetação e uso de reservatórios de retenção das águas pluviais. "A transformação dos anfiteatros de nascentes em áreas verdes já induzirá o estímulo à infiltração, à percolação e à evaporação de água; e à evaporação dos vegetais" (Schutzer, 2012 p. 198). A desocupação desses espaços quando possível deve ser realizada, permitindo assim a renaturalização dos cursos d'água e recuperação das suas margens conformando micro áreas de proteção permanente que possam ser usufruídas como lazer e recreação da população.

Nas encostas, vertentes das colinas e outeiros o processo de escoamento superficial também é predominante, são setores sensíveis ao processo de erosão e deslizamentos nas encostas quando desprovidos de densa vegetação ou sem tratamento de drenagem adequada. Por este motivo, recomenda-se para essas áreas arborização intensa além de parques e praças com uso de técnicas de terraceamento nos trechos desocupados a fim de proporcionar o estímulo à infiltração da água no solo, evaporação e evapotranspiração. Como forma de diminuir a velocidade de escoamento, algumas tipologias de infraestrutura verde devem ser incentivadas como jardins de chuva, canteiros pluviais, biovaletas, pisos drenantes, lagoas pluviais além de outras técnicas de retenção de água nas edificações como tetos verdes e cisternas.

As planícies aluviais ou várzeas são áreas mais baixas e planas que recebem águas e outros sedimentos dos compartimentos mais elevados. Esses compartimentos apresentam permanentemente seus solos úmidos que, quando não ocupados, conformam lagoas e espaços alagados. As áreas pertencentes a este compartimento são apropriadas para o armazenamento de água temporário ou constante devendo ser destinadas a parques com arborização intensa e espaços naturais que atuam na contenção de água temporária ou constante 
INFRAESTRUTURA VERDE APLICADA AO ALTO E MÉDIO CURSO DO RIO TREMEMBÉ

\section{CAPÍTULO 5 | APLICAÇÃO DA INFRAESTRUTURA VERDE}

como lagoas pluviais e bacias de detenção- ajudando a amenizar o transbordamento de córregos e rios. Ocupações voltadas para uso institucional que formem espaços de múltiplo uso podem ser introduzidas além de ocupações voltadas para uso residencial, comercial e serviços que podem ser introduzidas nos trechos mais largos e amplos caso uma boa permeabilidade for mantida nos compartimentos mais elevados. As ocupações devem ser de baixa densidade devendo também respeitar as áreas de proteção mínima estabelecidas pelo Código Florestal.

Aa áreas referentes ao Parque Estadual da Cantareira e ao Parque Estadual Horto Florestal são bastante sensíveis e prestam relevantes serviços ambientais para o município de São Paulo. Por este motivo, a cobertura vegetal de ambos os parques deve ser totalmente preservada.

\subsection{DIRETRIZES DE INFRAESTRUTURA VERDE PARA A ÁREA DE ESTUDO}

Para a elaboração das diretrizes de infraestrutura verde foram identificadas primeiramente áreas existentes capazes de colaborar para o funcionamento da rede a exemplo de regiões florestadas, praças, áreas verdes públicas, jardins privativos, canteiros ou rotatórias viárias, áreas ripárias incluindo rios, córregos e áreas alagáveis. Estas áreas, somadas às intervenções propostas a seguir, permitem, juntas, a criação de um sistema de áreas naturais que liga a matriz ecológica da Serra da Cantareira ao alto e médio curso do rio Tremembé e seus afluentes.

O sistema verde-azul proposto é benéfico na medida em que permite que os elementos naturais desempenhem seus serviços de maneira adequada, evitando assim transtornos relacionados à drenagem urbana e custos com soluções técnicas antrópicas. A ligação proposta, formada por atributos ecológicos, também beneficia a população por ofertar espaços para recreação e bem-estar, este último derivado da proximidade entre as habitações e a natureza. 
INFRAESTRUTURA VERDE APLICADA AO ALTO E MÉDIO CURSO DO RIO TREMEMBÉ

\section{CAPÍTULO 5 | APLICAÇÃO DA INFRAESTRUTURA VERDE}

A estrutura verde-azul proposta pode, ainda, ser ampliada em direção às outras áreas vegetadas pertencentes à matriz ecológica da Serra da Cantareira, com a função de reabilitar os serviços ambientais perdidos na região além de oferecer outras opções de lazer e fortalecer a integração social de forte caráter simbólico para o distrito.

Para que a rede proposta possa de fato desempenhar suas funções será necessário a incorporação de áreas consideradas vitais para o desempenho das funções ambientais comprometidas pelas intervenções urbanas.

As áreas que se encontram sem ocupação foram transformadas em áreas verdes permeáveis privadas ou públicas, estas últimas conformando espaços de lazer para a população onde também é viável a instalação de hortas comunitárias e jardins. As vias também foram transformadas em elementos cooperantes para a rede de infraestrutura verde por meio da aplicação de tipologias como jardins de chuva, biovaletas e piso permeável de acordo com o compartimento ambiental em que se localizam. Quando possível, implementação da arborização também é recomendada nas calçadas das ruas bem como ao longo de todas as áreas livres, públicas e privadas. A reconfiguração das vias e dos espaços livres deve ser acompanhada da diminuição da impermeabilidade dos lotes e incentivo à adoção de medidas ecológicas como telhados verdes e artifícios de armazenamento das águas pluviais e exemplo das cisternas.

Para os espaços localizados no compartimento dos outeiros, colinas e pequenos espigões secundários foram pensadas soluções que incentivasse a permeabilidade do solo. Nesse sentido, o desenho das vias deve ser trabalhado a fim de receber jardins de chuva ou canteiros pluviais, este último utilizado quando a largura da via for mais estreita. As calçadas também podem combater a impermeabilização do solo nesse compartimento por meio da adoção de pavimentos permeáveis e as vias com o pavimento drenante. As edificações, por sua vez, deverão receber telhados verdes capazes de realizar a captação das águas das chuvas e posterior despejo nas áreas permeáveis, que deverão ser implementadas nos lotes. 
INFRAESTRUTURA VERDE APLICADA AO ALTO E MÉDIO CURSO DO RIO TREMEMBÉ

\section{CAPÍTULO 5 | APLICAÇÃO DA INFRAESTRUTURA VERDE}

Os compartimentos denominados encostas, vertentes das colinas e outeiros são caracterizados principalmente pelo processo de escoamento superficial. Por este motivo, as vias nesses locais foram trabalhadas para receberem tipologias de infraestrutura verde do tipo biovaletas que atuam na diminuição da velocidade de escoamento além de contribuírem parcialmente para o processo de infiltração dessas áreas. As calçadas devem receber pisos permeáveis e os lotes devem contribuir com a oferta de áreas verdes permeáveis colaborando assim para a criação de mais pontos que atuem na diminuição do escoamento superficial nesse tipo de compartimento. Para os lotes, são indicadas a implantação de cisternas que também colaboram com a redução do escoamento superficial na medida em que a água recolhida pode ser aproveitada para irrigar jardins e hortas comunitárias ou utilizada para qualquer outra atividade que não exija água potável.

Os compartimentos nomeados anfiteatros onde estão as nascentes são configurados por áreas extremamente sensíveis, úmidas e de grande importância ecológica. Ao longo do processo de urbanização estas áreas foram ocupadas de maneira indevida dando origem à espaços impermeáveis que margeiam corpos hídricos canalizados ou mesmo tamponados. Diante disto, estas mesmas áreas precisam ser reservadas e direcionadas à constituição de parques ou áreas de lazer, córregos precisam ser renaturalizados com suas nascentes devidamente protegidas e delineadas por densa vegetação, induzindo o estímulo à infiltração, percolação e à evaporação da água. Nos casos em que esse tipo de transformação não seja possível devido à ocupação já estabelecida nesse compartimento, a edificação existente deve prever o controle do escoamento superficial por meio de telhados verdes e da adoção de reservatórios de retenção das águas pluviais. Além disso, as vias deverão receber intensa arborização que realizarão a interceptação da água da chuva pelas copas das árvores atuando na diminuição do aporte das águas pluviais em direção aos rios e realizarão a filtragem da poluição que é carregada para o sistema hídrico

O compartimento das planícies aluviais é predominante na área de estudo o que justifica a presença de solos permanentemente úmidos e muitas áreas propícias à alagamentos. Para combater os transtornos relativos à drenagem 
INFRAESTRUTURA VERDE APLICADA AO ALTO E MÉDIO CURSO DO RIO TREMEMBÉ

\section{CAPÍTULO 5 | APLICAÇÃO DA INFRAESTRUTURA VERDE}

após longos períodos de chuva, a prefeitura começou a pôr em prática o "Plano de Contenção de Enchentes da Bacia Hidrográfica do Tremembé" o qual prevê a construção de 06 piscinões, sendo 04 deles localizados na área de estudo.

Como descrito no capítulo 03, estes piscinões propostos funcionarão apenas como medidas estanques dentro de uma malha urbana impermeabilizada, falhando em solucionar a verdadeira raiz do problema. Os chamados piscinões ou bacias de detenção podem ser entendidos como suplementos ao sistema convencional de condução das águas pluviais com apenas influência quantitativa, já que o volume do escoamento superficial continua o mesmo a jusante. Além disso, estas estruturas voltadas para o armazenamento de água não substituem as funções estruturais desempenhadas pelos corpos d'águas e suas matas ciliares tais como permeabilidade, filtragem e purificação das águas pluviais além da criação de habitat de espécies.

Diante destas limitações que as estruturas convencionais dos piscinões apresentam, o plano de infraestrutura verde propõe uma readequação desses protótipos em andamento vão ao encontro de respostas naturais de cunho mais sustentável e resilientes que, além de contribuírem para os problemas de drenagem, atuarão como um recurso de fundamental importância para os ecossistemas e para as pessoas. Os reservatórios de detenção que já foram construídos ou que estão em processo de construção deverão ser transformados em estruturas que funcionem não só como uma unidade de reserva as águas durante algum tempo, porém também como um elemento que realize o tratamento da qualidade destas e que esteja integrado com a paisagem do seu entorno.

Esse tratamento realizado no interior dos reservatórios poderá ser feito por meio da adoção de espécies vegetais de zonas úmidas ou alagadas capazes de realizar a filtragem dos poluentes, promovendo assim a melhoria da qualidade das águas a jusante. Já a integração do reservatório com a paisagem circundante poderá ser feita por meio de travessias elevadas que permitam o fluxo de pedestres ao longo desses espaços vegetados. 
INFRAESTRUTURA VERDE APLICADA AO ALTO E MÉDIO CURSO DO RIO TREMEMBÉ

\section{CAPÍTULO 5 | APLICAÇÃO DA INFRAESTRUTURA VERDE}

As outras áreas livres existentes no compartimento das planícies aluviais que ainda não receberam obras de reservatórios serão transformadas em parques com arborização intensa e lagoas pluviais as quais ajudarão, associadas às novas estruturas de detenção, na amenização de alagamentos ou transbordamento dos corpos d'água. Os processos de detenção e contenção das águas também são propostos de maneira descentralizada ao longo de toda a extensão dos compartimentos da área de estudo. Caso ocorra uma falha pontual, por exemplo, a mesma pode ser compensada pelo funcionamento das demais tipologias de infraestrutura verde.

Ainda no contexto do compartimento das planícies aluviais, sugere-se a recomposição de alguns trechos da várzea do Rio Tremembé com a criação de um corredor verde que deve abrigar matas ciliares e parques lineares. Alguns afluentes do mesmo rio também poderão receber obras de renaturalização quando possível devolvendo à paisagem a função ambiental desses canais e promovendo assim uma nova relação do espaço urbano e com os cursos d'água que permeiam a região. 
INFRAESTRUTURA VERDE APLICADA AO ALTO E MÉDIO CURSO DO RIO TREMEMBÉ

\section{CAPÍTULO 5 | APLICAÇÃO DA INFRAESTRUTURA VERDE}

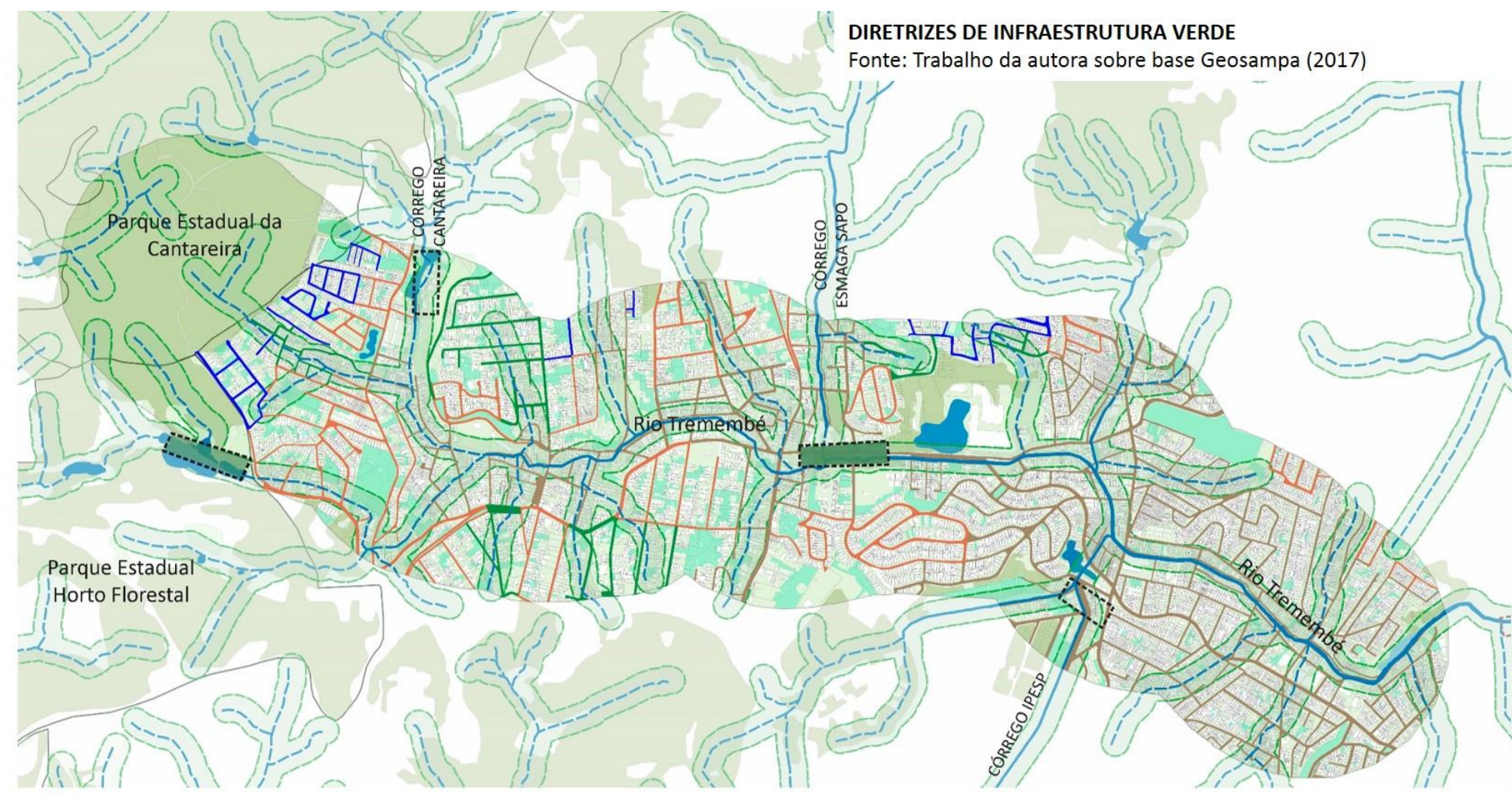

Legenda

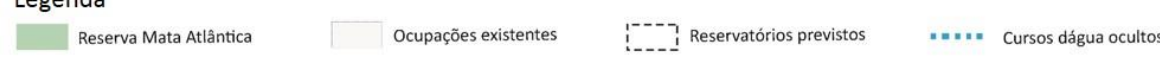

Áreas verdes existentes Reservatórios em construção —— Cursos dágua a céu aberto

TIPOLOGIAS DE INFRAESTRUTURA VERDE PROPOSTAS

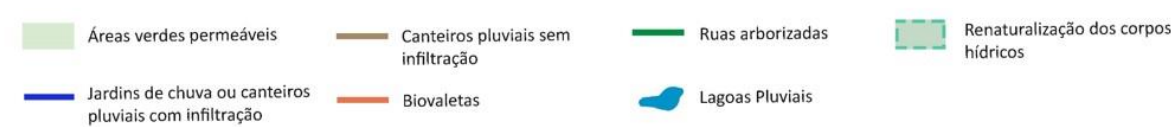

Figura 130- Mapa que aponta as diretrizes de infraestrutura verde propostas para a área de estudo. Fonte: Trabalho da autora sobre base Geosampa. 


\section{CAPÍTULO 5 | APLICAÇÃO DA INFRAESTRUTURA VERDE}

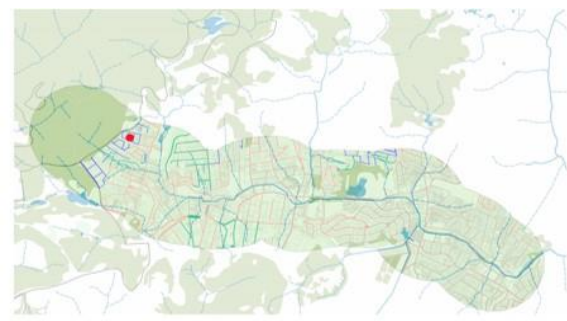

Localização na buffer zone -

Rua Manoel Vieira da Cruz

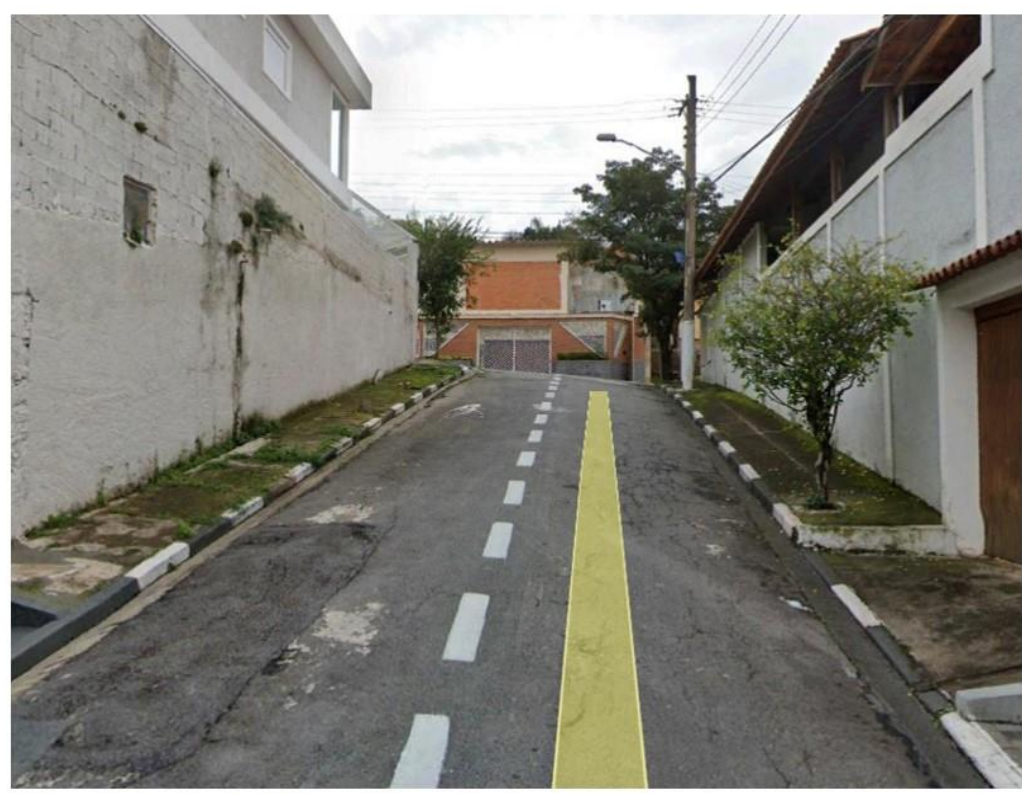

Situação atual -Rua Manoel Vieira da Cruz pavimento permeável.
DIRETRIZES DE INFRAESTRUTURA VERDE - ILUSTRAÇÃO | Fonte: Trabalho da autora (2019)

Rua Manoel Vieira da Cruz pertencente ao compartimento "outeiros, colinas e pequenos espigões secundários". Para incentivar a permeabilidade neste local, recomenda-se que o desenho das ruas esteja associado aos jardins de chuva ou canteiros pluviais. As calçadas também devem atuar na permeabilidade do solo por meio do

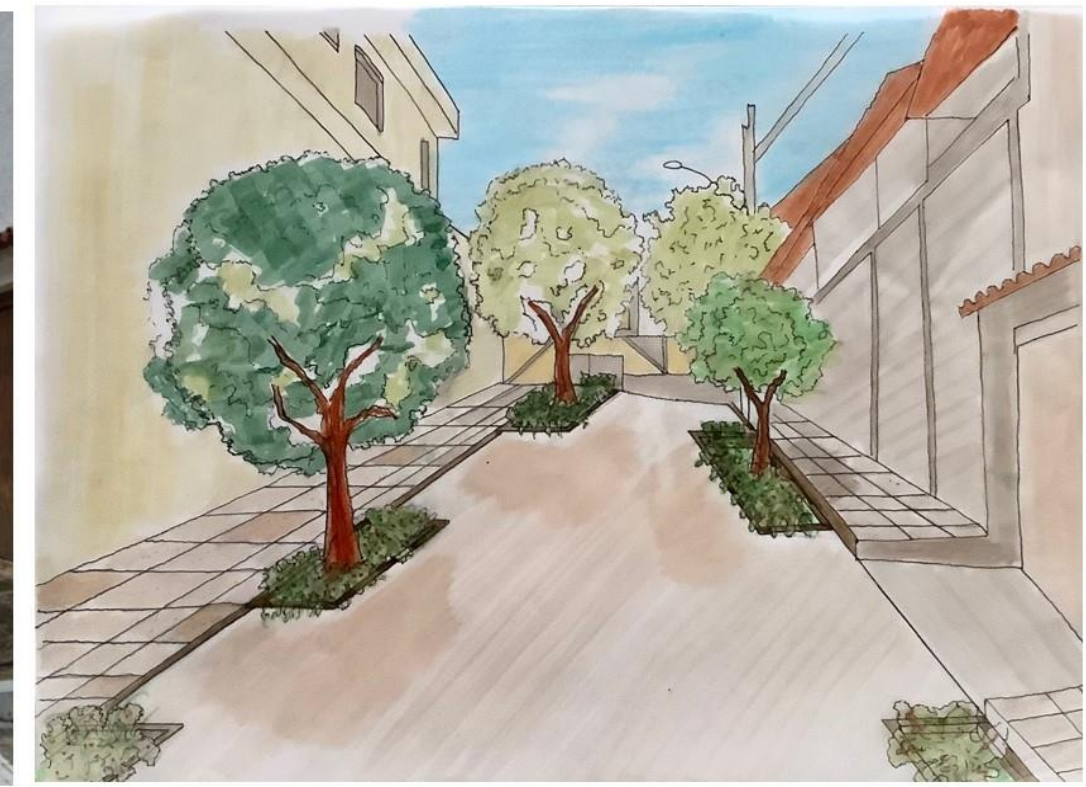

Proposta- Rua Manoel Vieira da Cruz

Figura 131- Diretrizes de infraestrutura verde para a área de estudo. Fonte: Trabalho da Autora (2020). 
INFRAESTRUTURA VERDE APLICADA AO ALTO E MÉDIO CURSO DO RIO TREMEMBÉ

\section{CAPÍTULO 5 | APLICAÇÃO DA INFRAESTRUTURA VERDE}

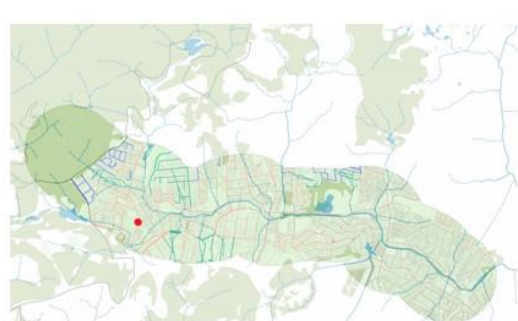

Localização na buffer zone -

Rua Luís Carlos Gentile de Laet

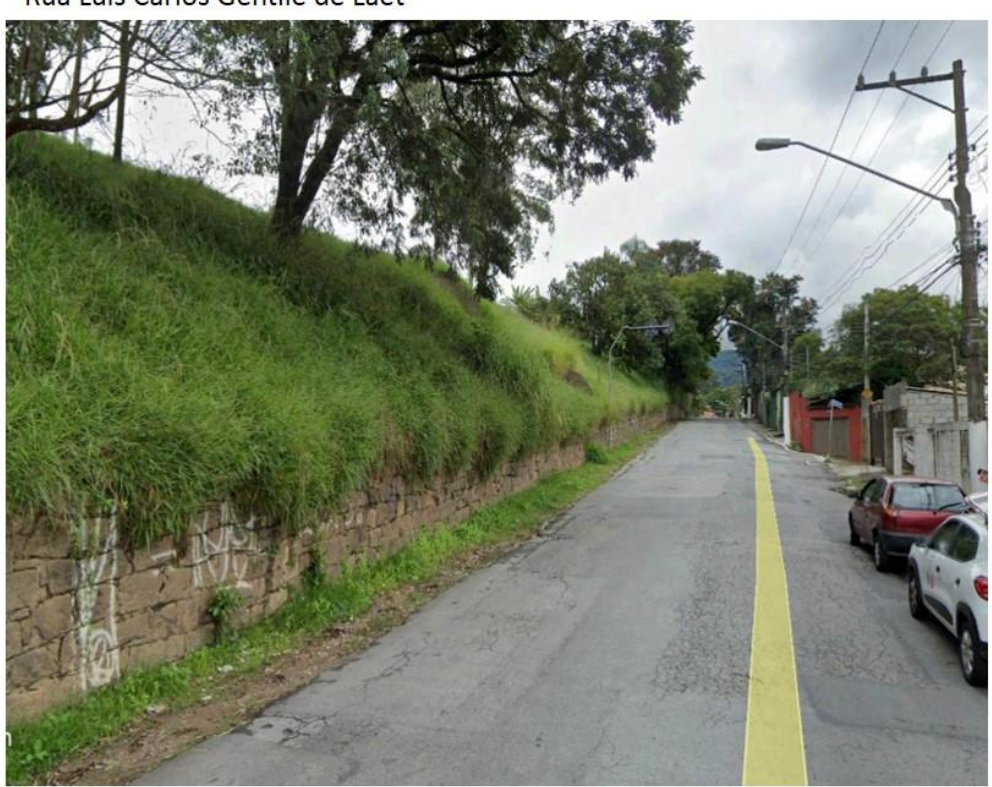

Situação atual - Rua Luís Carlos Gentile de Laet
DIRETRIZES DE INFRAESTRUTURA VERDE - ILUSTRAÇÃO | Fonte: Trabalho da autora (2019)

Rua Luís Carlos Gentile de Laet pertencente ao compartimento "encostas, vertente das colinas e outeiros". Para reduzir o escoamento superficial neste local, recomenda-se a implantação de áreas permeáveis que também sirvam como espaço de convívio para a população. Além disso, recomenda-se a implantação de biovaletas associadas ao desenho das ruas, pavimentos permeáveis e plantação de mais árvores.

Figura 132- Diretrizes de infraestrutura verde para a área de estudo. Fonte: Trabalho da Autora (2020). 


\section{CAPÍTULO 5 | APLICAÇÃO DA INFRAESTRUTURA VERDE}

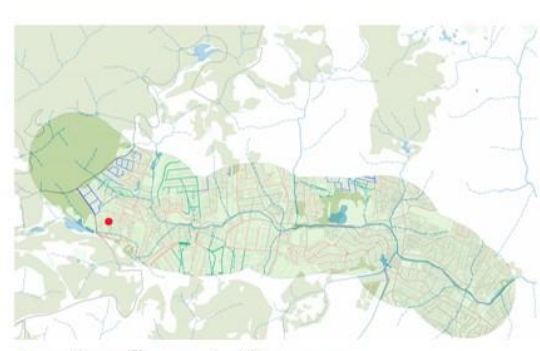

Localização na buffer zone -

Rua Alexandre Ribeiro

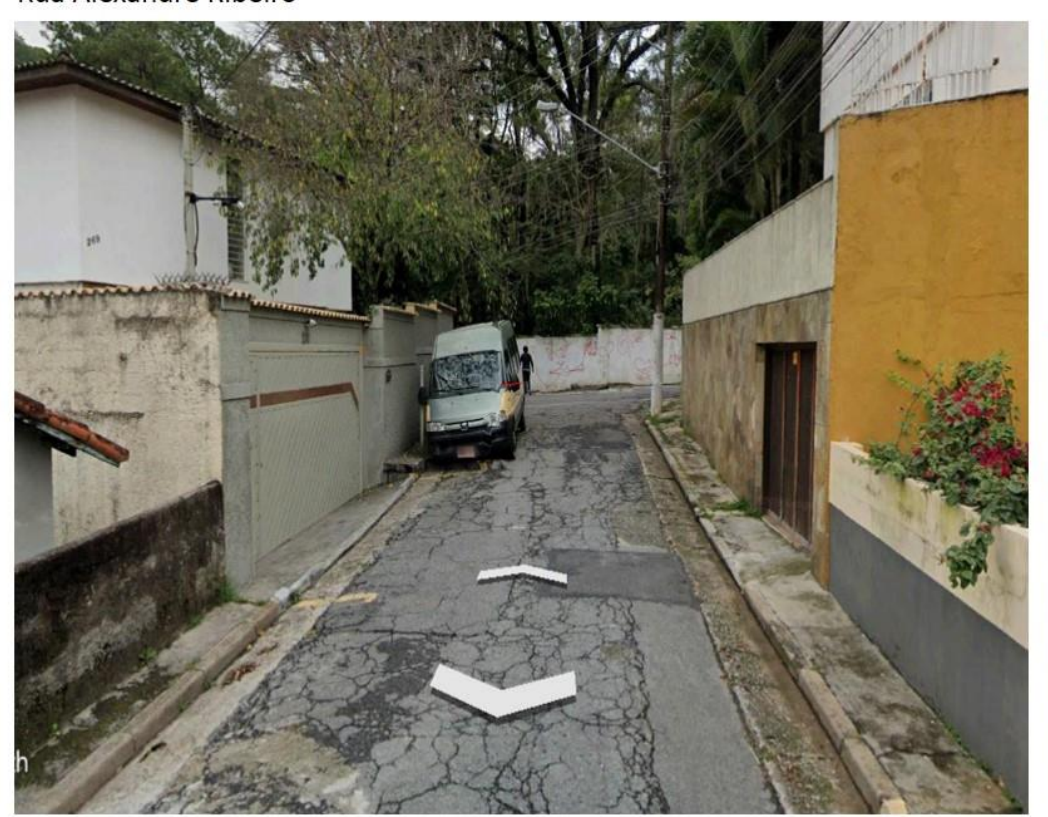

Situação atual -Rua Alexandre Ribeiro

\section{DIRETRIZES DE INFRAESTRUTURA VERDE - ILUSTRAÇÃO | Fonte: Trabalho da autora (2019)}

Rua Alexandre Ribeirão pertencente ao compartimento "encostas, vertente das colinas e outeiros". Com o intuito de reduzir o escoamento superficial nesta área, recomenda-se a implantação de biovaletas associadas ao desenho das ruas além de pavimentos permeáveis nas calçadas.

Figura 133- Diretrizes de infraestrutura verde para a área de estudo. Fonte: Trabalho da Autora (2020). 


\section{CAPÍTULO 5 | APLICAÇÃO DA INFRAESTRUTURA VERDE}

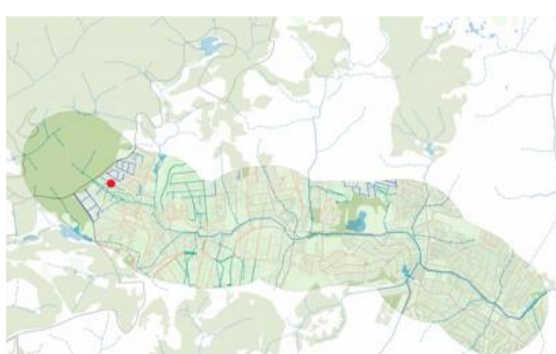

Localização na buffer zone -

Rua Miguel Álvares

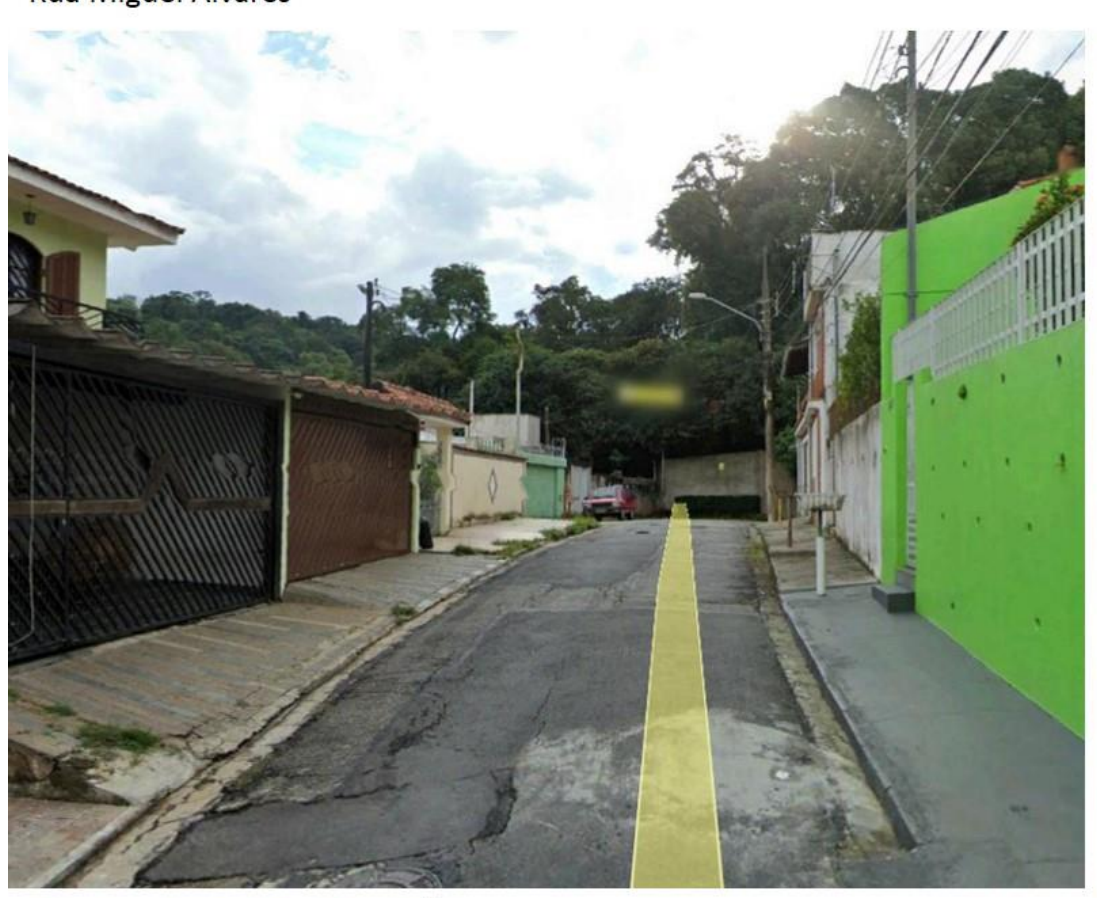

Situação atual - Rua Miguel Álvares

DIRETRIZES DE INFRAESTRUTURA VERDE - ILUSTRAÇÃO | Fonte: Trabalho da autora (2019)

Rua Miguel Alves pertencente ao compartimento "anfiteatros onde estão as nascentes".

Em casos como este, onde nota-se uma ocupação de residências já estabelecida, as vias deverão receber intensa arborização com o intuito de diminuírem o aporte das águas pluviais em direção aos corpos d'água além de realizarem a filtragem da poluição. Recomenda-se também nas calçadas a implantação de pavimentos permeáveis.

Figura 134- Diretrizes de infraestrutura verde para a área de estudo. Fonte: Trabalho da Autora (2020)

Figura 134- 
INFRAESTRUTURA VERDE APLICADA AO ALTO E MÉDIO CURSO DO RIO TREMEMBÉ

\section{CAPÍTULO 5 | APLICAÇÃO DA INFRAESTRUTURA VERDE}

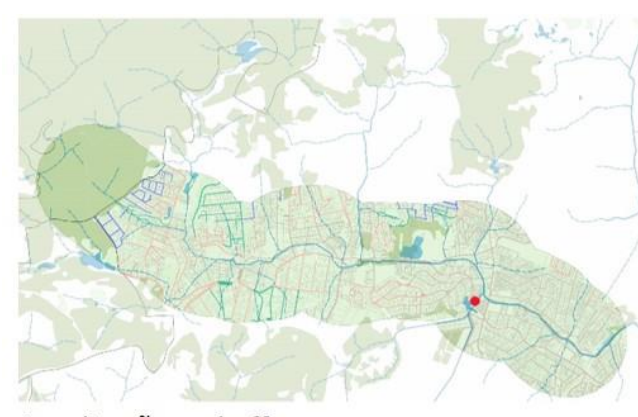

Localização na buffer zone -

Rua Manuel Gaya

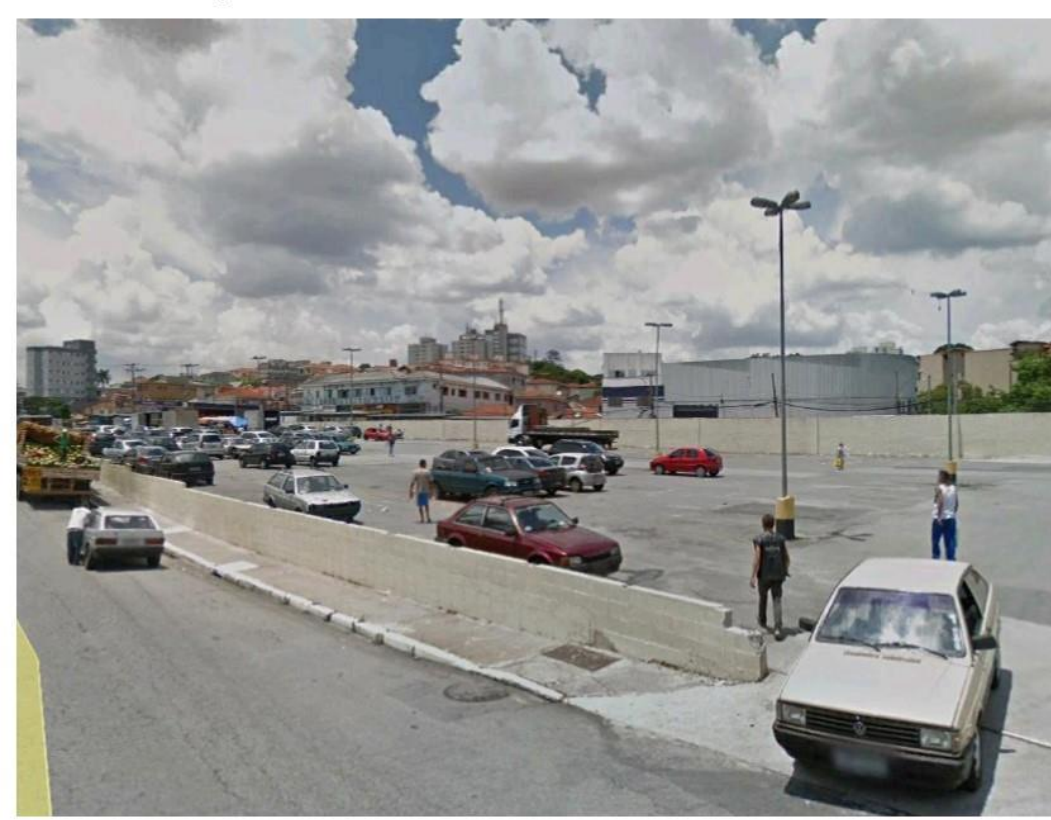

Situação atual - Rua Manuel Gaya
DIRETRIZES DE INFRAESTRUTURA VERDE - ILUSTRAÇÃo | Fonte: Trabalho da autora (2019)

Espaço onde hoje funciona um estacionamento na rua Manuel Gaya pertencente ao compartimento "planície aluvial“. Neste lugar está prevista a construção do reservatório de detenção R4. No entanto, alinhado às diretrizes de infraestrutura propostas, recomenda-se que este espaço seja transformado em parque com uma lagoa pluvial para amenizar os alagamentos e transbordamentos dos corpos d'água. Dessa forma, esta solução funcionaria não só como um reservatório de água, mas também promoveria o tratamento das águas pluviais por meio da vegetação e funcionaria também como um espaço de lazer e recreação integrado à paisagem circundante.

Figura 135- Diretrizes de infraestrutura verde para a área de estudo. Fonte: Trabalho da Autora (2020). 


\section{CAPÍTULO 5 | APLICAÇÃO DA INFRAESTRUTURA VERDE}

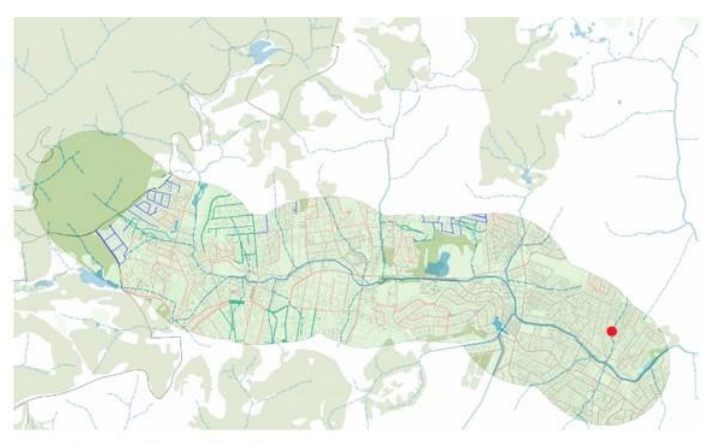

Localização na buffer zone -

Rua dos Guatambús

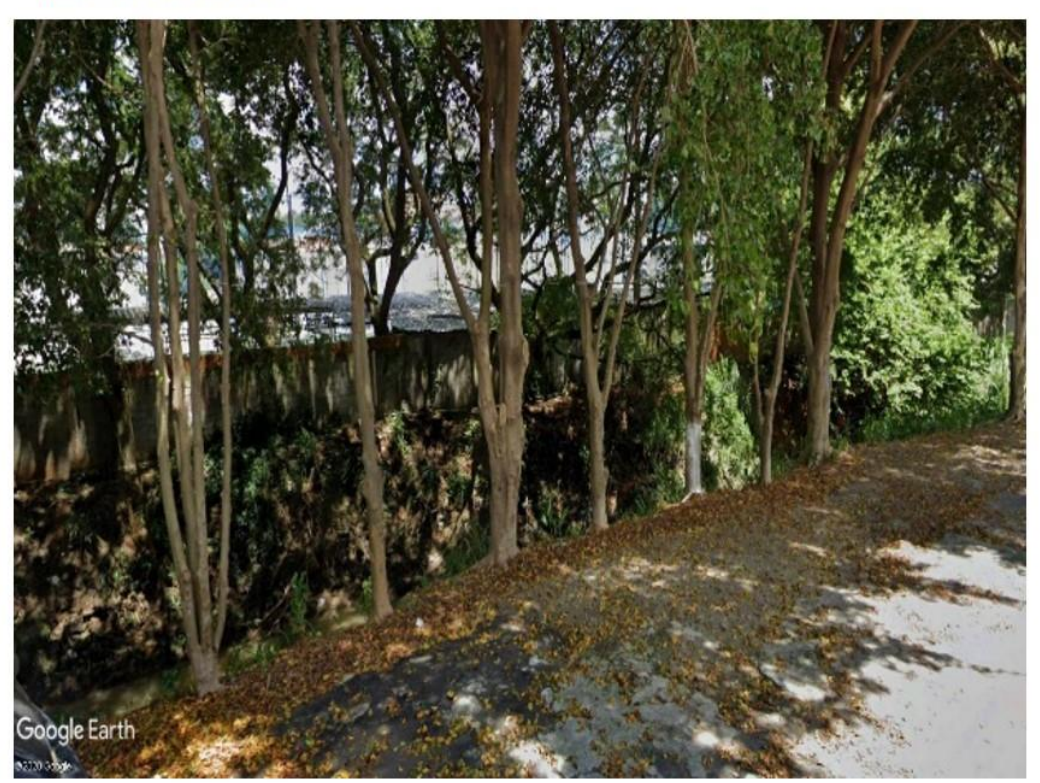

Situação atual - Rua dos Guatambús
DIRETRIZES DE INFRAESTRUTURA VERDE - ILUSTRAÇÃO | Fonte: Trabalho da autora (2019)

Rua dos Guatambús pertencente ao compartimento "planície aluvial“. Sugere-se a recomposição de trechos do Rio Tremembé com a criação de um corredor verde que deve abrigar matas ciliares e um parque linear. A intervenção tem como objetivo devolver a função ambiental do curso hídrico e atribuir uma nova relação entre as água e o espaço urbano.

Figura 136- Diretrizes de infraestrutura verde para a área de estudo. Fonte: Trabalho da Autora (2020). 


\section{CONSIDERAÇÕES FINAIS}

As ações que conciliam as particularidades da natureza aos traços cidade foram, em grande parte, negligenciadas ao longo do tempo. Considerados em geral como atribuições estéticas ou como meros complementos à paisagem, os espaços naturais cederam lugar às intervenções urbanas que os transformaram em elementos descartáveis e passíveis de modificações. Medidas deste caráter acumularam inúmeros efeitos negativos o que nos faz reconhecer cada vez mais que, a cidade, tida como uma das maiores intervenções do ser humano sobre a terra, não está dissociada dos processos naturais que incidem sobre sua base física. A partir dos estudos realizados nessa dissertação, a infraestrutura verde se mostra como uma ferramenta capaz de resgatar a natureza enquanto parte integrante e provedora de funções essenciais ao espaço urbano.

A infraestrutura verde orienta o desenho da paisagem baseado nos serviços ambientais prestados pela natureza ao mesmo tempo em que considera as dinâmicas atuantes nos compartimentos do mosaico urbano. Com base nas pesquisas ancoradas na temática do planejamento ambiental e suas aproximações com os conceitos de ecologia, fica claro que os espaços verdes e os cursos d'água devem ser entendidos como parte da infraestrutura das cidades, uma vez que, quando interligados, atuam na formação de uma grande rede permeável capaz de oferecer benefícios que ultrapassam requisitos estéticos alcançando efeitos na qualidade ambiental urbana do território.

As diretrizes de infraestrutura verde propostas para o trecho que envolve 0 alto e médio curso do Tremembé buscaram identificar além das áreas de conservação, a conciliação entre os processos naturais e a ocupação já estabelecida neste local. Apesar da área de estudo incluir muitas ruas arborizadas e outros espaços vegetados que the atribuem um caráter bucólico, a infraestrutura verde proposta busca alcançar benefícios que vão além dessa concepção. Se empenha em realizar a articulação entre áreas verdes, corpos d'água e equipamentos públicos com vistas a proporcionar paisagens que 
INFRAESTRUTURA VERDE APLICADA AO ALTO E MÉDIO CURSO DO RIO TREMEMBÉ

\section{CAPÍTULO 5 | APLICAÇÃO DA INFRAESTRUTURA VERDE}

desempenhem outras funções importantes além do lazer, contemplação ou embelezamento como prevenção de enchentes e deslizamentos, aumento da biodiversidade, melhoria do microclima além de promoção e manutenção dos fluxos bióticos e abióticos.

A proposição de tipologias de cunho sustentável que trabalham na retenção de águas superficiais se revelam como soluções paisagísticas de alto desempenho para a área, ao contrário dos planos de drenagem tradicionais que já estão sendo aplicados, como os reservatórios de detenção ou famosos "piscinões". Em contraposição a este modelo, a infraestrutura verde busca associar medidas que envolvem o manejo das águas ao mesmo tempo em que promove novas relações da população com o espaço urbano e os sistemas naturais que o conformam. Nesse sentido, ao contrário das intervenções urbanísticas usuais, as soluções ancoradas nos princípios da infraestrutura verde apontadas possuem amplas funções e são capazes de proporcionar benefícios para as áreas muito mais abrangentes.

Diante da proximidade da área de estudo com a Serra da Cantareira e outros fragmentos consideráveis da Mata Atlântica, a rede proposta tem potencial para alcançar proporções ainda maiores. A sua extensão em direção às áreas mais altas pertencentes à matriz verde da Cantareira, a qual compreende nascentes e densa vegetação, poderia resultar na ampliação dos serviços ambientais ofertados pela infraestrutura verde, colaborando para a formação de relações mais harmônicas entre a área florestada e o espaço urbano que dela se aproxima.

Entretanto, é preciso considerar que, devido a existência de uma ocupação já consolidada na área de estudo, a aplicação da infraestrutura verde neste recorte encontra grandes desafios que requerem esforços advindos das esferas públicas e de uma tomada de consciência quanto à relevância desse tipo de instrumento na transformação dos territórios de acordo com as dinâmicas ambientais. Apesar de já ter sido bastante divulgada no meio acadêmico, sua aplicação carece de estudos mais aprofundados voltados às formas de ocupação que moldam os territórios urbanos brasileiros. Nessa conjuntura, o método do zoneamento ambiental desenvolvido por Schutzer com base na análise 
INFRAESTRUTURA VERDE APLICADA AO ALTO E MÉDIO CURSO DO RIO TREMEMBÉ

\section{CAPÍTULO 5 | APLICAÇÃO DA INFRAESTRUTURA VERDE}

geomorfológica de Aziz Ab'Saber foi de fundamental importância para o desenvolvimento das proposições presentes neste trabalho, apoiadas nas categorias de análise da geomorfologia da área de estudo.

Por fim, toma-se a infraestrutura verde como uma ferramenta capaz de reestruturar a paisagem da área de estudo concedendo-lhe a ativação dos processos naturais em concordância com suas peculiaridades urbanas existentes. Essa ferramenta se estabelece com enfoque na construção de um ambiente urbano mais sustentável e resiliente por meio da restauração das funções do ecossistema seja por meio da formação de espaços multifuncionais ou criações de conexões que fomentam interações diversas entre a natureza e as pessoas. 


\section{REFERÊNCIAS BIBLIOGRÁFICAS}

ABRIL, Marta Juliana. PISCINÕES. O Projeto de Retenção da água pluvial na Região Metropolitana de São Paulo. Dissertação (Mestrado)- Faculdade de Arquitetura e Urbanismo, Universidade de São Paulo, São Paulo, 2017.

AB'SÁBER, Aziz Nacib. Geomorfologia do Sítio Urbano de São Paulo. 1 ed. Cotia: Ateliê Editorial, 2007.

AB'SÁBER, Aziz Nacib. Um conceito de geomorfologia a serviço das pesquisas sobre o Quaternário. In: Geomorfologia, 18. São Paulo, IGEOG/ USP, 1969.

AHERN, Jack F. Greenways in the USA: theory, trends and prospects. In R. Jongman e G. Pungetti (Eds.), Ecological Networks and Greenways - Concept, Design, Implementation. 34-55. Cambridge: Cambridge University Press, 2003.

ALBERTI, Marina. Advances in Urban Ecology. Springer, New York, 2008.

ANDRADE, Rivail Vanin de. Complexidade dinâmica: água, expansão urbana e espaços livres públicos- o processo de construção da paisagem do Parque Iguaçu, Curitiba- PR. Tese de Doutorado. Faculdade de Arquitetura e Urbanismo da Universidade de São Paulo , 2009.

AZEVEDO, Aroldo de. A cidade de São Paulo. vol.2. Associação dos Geógrafos brasileiros e Cia. Ed. Nacional: 1958.

BÉLANGER, P. Landscape as infrastructure. Landscape Journal. V.28, n.1,p.79-95, 2009.

BENEDICT, Mark A.; MCMAHON, Edward T. Green infrastructure: Linking landscapes and communities. Washington: Island Press, 2006.

BONZI, R. S. Andar sobre Água Preta: a aplicação da Infraestrutura Verde em áreas densamente urbanizadas. Dissertação (Mestrado em Arquitetura e Urbanismo). Universidade de São Paulo: FAUUSP, 2015.

BONZI, Ramón Stock Bonzi. Paisagem como infraestrutura. In: PELLEGRINO, Paulo; MOURA, Newton Becker (org). Estratégias para uma infraestrutura verde. Barueri: Manole, 2017. cap.1, p. 1-24.

BRITTO, Eduardo. São Paulo Tramway Tremembé. São Paulo: E. Britto, 1999. 
INFRAESTRUTURA VERDE APLICADA AO ALTO E MÉDIO CURSO DO RIO TREMEMBÉ CAPÍTULO 5 | APLICAÇÃO DA INFRAESTRUTURA VERDE

CANHOLI, Aluísio Pardo. Drenagem urbana e controle de enchentes. São Paulo: Oficina de Textos, 2014.

CARVALHO, Mario Cesar. Conclusão de trecho norte do Rodoanel levará a gasto extra de até R\$ 1 bilhão. Jornal Folha de São Paulo. São Paulo, 19 ago. 2019. Disponível em: <https://www1.folha.uol.com.br/poder/2019/08/conclusao-detrecho-norte-do-rodoanel-levara-a-gasto-extra-de-ate-r-1-bi.shtml>. Acesso em 07 jan. 2019.

CORMIER, Nathaniel S.; PELLEGRINO, P. Infraestrutura Verde: uma Estratégia Paisagística para a Água Urbana. Paisagem e Ambiente: ensaios: FAUUSP. São Paulo, N.25, p. 127-142, 2008. Disponível em: < http://www.revistas.usp.br/paam/article/view/105962/111750>. Acesso em 03 ago. 2018.

DERSA, Desenvolvimento Rodoviário S.A. Estudo de impacto ambiental (EIA): programa rodoanel Mario Covas - trecho norte. Consórcio JPG \& PRIME Engenharia. DERSA/Secretaria de Transportes / Governo do Estado de São Paulo, 2010. 12 vols.

DRAMSTAD, Wenche E.; OLSON, James D.; FORMAN, Richard T. T. Landscape Ecology Principles in Landscape Architecture and Land-Use Planning. Cambridge: Harvard University Graduate School of Design, Island Press and ASLA, 1996.

ESTADO DE SÃO PAULO. Secretaria de Logística e Transportes. Dersa publica edital de pré- qualificação para obras do trecho norte do rodoanel. Disponível em: http://www.dersa.sp.gov.br/comunicacao/noticias/rodoanelnorte/dersa-publica-edital-de-pre-qualificacao-para-obras-do-trecho-norte-dorodoanel/. Acesso em 07 jan. 2019.

FIREHOCK, Karen. A short history of the term green infrastructure and selected literature. Green Infrastructure Center, Charlotesville, 2010. Disponível em: < http://www.gicinc.org/PDFs/Gl\%20History.pdf>. Acesso em 14 de out. 2019.

FORMAN, Richard T. T. Land Mosaics: The Ecology of Landscapes and Regions. Cambridge: Cambridge University Press, 1995.

FORMAN, Richard T. T.; GODRON, M. Landscape ecology. New York: John Wiley \& Sons, 1986.

FORMAN, Richard T.T. Urban ecology and the arrangement of nature in urban regions. In: Ecological urbanism. Mostafavi, Mohsen e Doherty, Gareth (eds.). Harvard University e Lars Publishers, 2010. pp. 312-323.

FRANCO, Maria de Assunção R. Desenho ambiental: Introdução à Arquitetura da Paisagem com o Paradigma Ecológico. São Paulo: Annablume, 1997. 
INFRAESTRUTURA VERDE APLICADA AO ALTO E MÉDIO CURSO DO RIO TREMEMBÉ CAPÍTULO 5 | APLICAÇÃO DA INFRAESTRUTURA VERDE

FRANCO, Maria de Assunção Ribeiro (org.). São Paulo nas mudanças climáticas: cenários ambientais para a resiliência urbana. São Paulo: Annablume, 2019.

FRANCO, Maria de Assunção Ribeiro. Infraestrutura verde em São Paulo: O caso do corredor verde Ibirapuera - Vila Lobos. Revista Labverde: FAUUSP. São Paulo, n.1,p. 134-154, out. 2010.

FRANCO, Maria de Assunção Ribeiro. Planejamento ambiental para a cidade sustentável. São Paulo: Annablume, 2000.

GARTLAND, L. Heat islands: understanding and mitigating heat urban areas. Published by Earthscan. UK and USA, 2008. 215p.

GEHL, Jan. Cidades para pessoas. São Paulo: Perspectiva, 2013.

HERZOG, Cecília Polacow. Cidade para todos: (re)aprendendo a conviver com a natureza. 1 ed. Rio de Janeiro: Mauad X; Inverde, 2013.

HERZOG, Cecília Polacow. Guaratiba Verde: subsídios para o projeto de infraestrutura verde em área de expansão urbana na cidade do Rio de Janeiro. Dissertação (mestrado)- Programa de Pós-Graduação em Urbanismo/PROURB da Universidade Federal do Rio de Janeiro, Rio de Janeiro, 2009.

HOUGH, Michael. City Form and Natural Process. Van Nostrand Reinhold Company, Berkshire, 1984.

HOUGH, Michael. Natureza e cidade. Barcelona: Editorial Gustavo Gili S.A.,1998.

IBGE. Manual Técnico de Geomorfologia. $2^{a}$ ed. Rio de Janeiro: Instituto Brasileiro de Geografia e Estatística, 2009. 175 p.

LAURIE, Michael. An Introduction to Landscape Architecture. New York: Elsevier Science Publishing CO, 1978.

LEITÃO, André B.; AHERN, Jack. Applying landscape ecological concepts and metrics in sustainable landscape planning. Landscape and Urban Planning (Elsevier Science B.V.) vol. 59, 2002. p. 65-93.

LEITE, Júlia Rodrigues. A paisagem entre a cidade e a natureza: a reserva da biosfera de São Paulo. In: PELLEGRINO, Paulo; MOURA, Newton Becker (org). Barueri, SP: Manole, 2017. cap. 5, p.79-100.

LOCATELLI, M. M. et al. Panorama atual da cobertura arbórea da cidade de São Paulo. Revista Labverde, v. 9, n. 1, p. 29-48, 2018.

MENEGUETTI, Karin Schwabe. Cidade- jardim, cidade sustentável: a estrutura ecológica urbana e a cidade de Maringá. Maringá: Eduem, 2009. 
INFRAESTRUTURA VERDE APLICADA AO ALTO E MÉDIO CURSO DO RIO TREMEMBÉ CAPÍTULO 5 | APLICAÇÃO DA INFRAESTRUTURA VERDE

METZGER, Jean Paul. O que é ecologia de paisagens? Biota Neotrop. Campinas , v. 1, n. 1-2, p. 1-9, 2001.

MILANO, M. S.; DALCIN, E. C. Arborização de Vias Públicas. 1. ed. Rio de Janeiro: Light, 2000. 226p.

MOSS, T. Battle of the systems? Changing styles of water recycling in Berlin. In: GUY, S.; MARVIN, S.; MOSS, T. Infrastructure in transition - networks, buildings, plans. Londres: Earthscan, 2001.

NDUBISI, Forster. Ecological Planning: a historical and comparative synthesis. Baltimore: The Johns Hopkins University Press, 2002.

NEWMAN, Peter; BEATLEY, Timothy; BOYER, Heather. Resilient Cities: Responding to Peak Oil and Climate Change. Washington, DC: Island Press, 2009.

ODUM, Eugene P. Ecologia. Rio de Janeiro: Guanabara, 1988.

PANZINI, Franco. Projetar a natureza: arquitetura da paisagem e dos jardins desde as origens até a época contemporânea. São Paulo, Editora Senac, 2013.

PELLEGRINO, Paulo Mesquita. Pode-se planejar a paisagem? In Paisagem e Ambiente: ensaios São Paulo: Faculdade de Arquitetura e Urbanismo, n¹3, dez de 2000. p. 159-180.

PELLEGRINO, Paulo. Paisagem como infraestrutura ecológica: a floresta urbana. In: PELLEGRINO, Paulo; MOURA, Newton Becker (org). Barueri, SP: Manole, 2017. cap. 4, p. 63-77.

RODRIGUES, Artur. Rodoanel: prefeitura exige 09 parques. Jornal Estadão. São Paulo, 25 set. 2013. Disponível em: <https://são paulo.estadao.com.br/noticias/geral,rodoanel-prefeitura-exige-9-parques-imp,1078491 >. Acesso em 07 jan. 2019.

ROSS, Jurandyr Luciano Sanches. Geomorfologia: ambiente e planejamento. São Paulo, Contexto, 2000, 84p.

ROWE, Peter G. Respirar, de novo. Revista Arquitetura e Urbanismo, São Paulo, n.234, p. 64-71, 2013.

SANDRE, Adriana Afonso. O Planejamento Ambiental à luz da Ecologia da Paisagem: Estudo Aplicado da Zona de Amortecimento do Parque Estadual da Cantareira. Dissertação de Mestrado. Faculdade de Arquitetura e Urbanismo de São Paulo, 2017.

SANDRE, Adriana Afonso. O Planejamento Ambiental à luz da Ecologia da Paisagem: Estudo Aplicado da Zona de Amortecimento do Parque Estadual 
INFRAESTRUTURA VERDE APLICADA AO ALTO E MÉDIO CURSO DO RIO TREMEMBÉ CAPÍTULO 5 | APLICAÇÃO DA INFRAESTRUTURA VERDE

da Cantareira. Dissertação de Mestrado. Faculdade de Arquitetura e Urbanismo de São Paulo, 2017.

SANTOS, Rosely Ferreira dos Santos. Planejamento Ambiental: teoria e prática. São Paulo: Oficina de textos, 2004.

SÃO PAULO (ESTADO), DAEE. Plano Diretor de Macrodrenagem da Bacia Hidrográfica do Alto Tietê PDMAT. São Paulo: DAEE, 1999.

SÃO PAULO (ESTADO), DAEE. Terceiro Plano Diretor de Macrodrenagem da Bacia Hidrográfica do Alto Tietê PDMAT-3. São Paulo: DAEE, 2014.

SÃo PAUlO (ESTADO). Secretaria do Meio Ambiente. Plano de manejo do Parque Estadual da Cantareira, 2009. Disponível em: <http://arquivos.ambiente.sp.gov.br/fundacaoflorestal/2012/01/PECantareira/Pl ano\%20de\%20Manejo/0.\%20P\%C3\%83\%C2\%A1ginas\%20Iniciais.pdf>. Acesso 16 de fev. 2019.

SÃO PAULO (Município). Secretaria do Verde e do Meio Ambiente/ Secretaria Municipal de Planejamento Urbano. Atlas Ambiental do Município de São Paulo. São Paulo: SVMA, 2004.

SÃO PAULO (Município). Secretaria do Verde e Meio Ambiente/ Secretaria Municipal de Planejamento Urbano. Vegetação Significativa do Município de São Paulo. São Paulo: SVMA, 1988.

SÃO PAULO (Município). Secretaria Municipal de Desenvolvimento Urbano. Manual de Drenagem e Manejo das Águas Pluviais. São Paulo: SMDU, 2012. 3 v.

SÃO PAULO (Município). Secretaria Municipal de Infraestrutura Urbana e Obras. Obras para contenção de enchentes no Córrego Tremembé serão entregues no segundo semestre. São Paulo, 2019. Disponível em: <https://www.prefeitura.sp.gov.br/cidade/secretarias/obras/noticias/?p=276687 .>. Acesso em 11 dez 2019.

SCHUTZER, José Guilherme. Cidade e meio ambiente: A apropriação do Relevo no Desenho Ambiental Urbano. São Paulo: Editora da Universidade de São Paulo, 2012.

SCHUTZER, José Guilherme. Resiliência urbana em São Paulo: questões geomorfológicas. In: FRANCO, Maria de Assunção Ribeiro (org.). São Paulo nas mudanças climáticas: cenários ambientais para a resiliência urbana. São Paulo: Annablume, 2019. Cap. 1, p.31-59.

SILVA, D.A.; CONTI, J.B.; YUHARA, C.H.; NAKAMURA, E.T. Definição de Critérios para a Delimitação de um Setor do Parque Estadual da Cantareira Seccionado pela Rodovia Fernão Dias (BR-381), São Paulo, Brasil. Revista Geográfica de América Central Número Especial EGAL, Costa Rica, p.1-13, 2011. 
SILVA, Stanley Plácido da Rosa. O Tramway da Cantareira e sua relação com desenvolvimento local: infraestrutura urbana e transporte de passageiros (1893-1965). 2018. 205 f. Tese (Doutorado em História Econômica)- Faculdade de Filosofia, Letras e Ciências Humanas da Universidade Estadual de São Paulo, São Paulo, 2018.

SPIRN, Anne W. 0 jardim de granito: a natureza no desenho da cidade. São Paulo: Edusp, 1995.

TARDIM, Raquel. Espaços livres: sistema e projeto territorial. Rio de Janeiro: 7 Letras, 2008.

TOMINAGA, Lídia Keiko; SANTORO, Jair; AMARAL, Rosângela do (org.). Desastres naturais: conhecer para prevenir. São Paulo: Instituto Geológico, 2015.

TRICART, J.J.L. 1979. Paysage et écologie. Revue de Géomorphologie dynamique: géodynamiqueexterne. Études intégrée du milieu naturel, XXVIII, n.3, p. $81-95$

VASCONCELLOS, Andréa Araujo de. Infraestrutura verde aplicada ao planejamento da ocupação urbana. Curitiba: Appris, 2015.

WU, Jianguo, HOBBS, Richard. Key issues and research priorities in landscape ecology: An idiosyncratic Synthesis. Landscape Ecology, n.17, p.355-365, 2002.

WU, Jianguo; HE, Chunyang; HUANG, Ganlin; YU, Deyoung. Urban Landscape Ecology: Past, Present and Future. In: NIEMELÄ, Jari. (ed.) Urban Ecology. Patterns, Processes and Applications. Oxford: Oxford University Press, 2011.

YU, Kongjian. The art of survival. Minneapolis, USA: Position Landscape Architecture, 2006. 